\title{
OPFICL OF
}

\section{BOHEDHE}

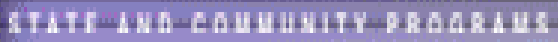

\section{Documentation for}

\section{FY2002 BTS GPRA Metrics}

Building Technology, State and Community Programs

Energy Efficiency and Renewable Energy

U.S. Department of Energy

January 2002

Prepared for Building Technology,

State and Community Programs

by Pacific Northwest National Laboratory 


\title{
DISCLAIMER
}

This report was prepared as an account of work sponsored by an agency of the United States Government. Neither the United States Government nor any agency thereof, nor Battelle Memorial Institute, nor any of their employees, makes any warranty, express or implied, or assumes any legal liability or responsibility for the accuracy, completeness, or usefulness of any information, apparatus, product, or process disclosed, or represents that its use would not infringe privately owned rights. Reference herein to any specific commercial product, process, or service by trade name, trademark, manufacturer, or otherwise does not necessarily constitute or imply its endorsement, recommendation, or favoring by the United States Government or any agency thereof, or Battelle Memorial Institute. The views and opinions of authors expressed herein do not necessarily state or reflect those of the United States Government or any agency thereof.

\author{
PACIFIC NORTHWEST NATIONAL LABORATORY \\ operated by \\ BATTELLE \\ for the \\ UNITED STATES DEPARTMENT OF ENERGY \\ under Contract DE-AC06-76RL01830
}

This document was printed on recycled paper. 


\section{Documentation for}

\section{FY2002 BTS GPRA Metrics}

Building Technology, State and Community Programs

Energy Efficiency and Renewable Energy

U.S. Department of Energy

D. B. Belzer

K. A. Cort

J. A. Dirks

D. J. Hostick

January 2002

Prepared for Building Technology, State and Community Programs

the U.S. Department of Energy under Contract DE-AC06-76RL01830

Pacific Northwest National Laboratory

Richland, Washington 99352 


\section{Executive Summary}

Pacific Northwest National Laboratory (PNNL) estimated the FY 2002 energy, environmental, and financial benefits (i.e., metrics) of the technologies and practices in the U.S. Department of Energy's (DOE's) Office of Building Technology, State and Community Programs (BTS). BTS is part of DOE's Office of Energy Efficiency and Renewable Energy (EE), which uses the estimates of benefits as part of its annual budget request.

This report includes a series of documents that detail the approach and methodology used to estimate future energy, environmental, and financial benefits produced by technologies and practices supported by BTS in the fiscal year 2002. An overview is provided that describes the GPRA process and the models used to estimate savings. The results of the forecasted energy savings, consumer cost savings, and carbon benefits for each of the 19 BTS programs are included in individual program summaries and overall results of the FY02 GPRA effort are summarized for all BTS programs. Technical appendixes include the FY02 GPRA Data Call as well as descriptions of the models used, baseline assumptions, and diffusion curve estimates. 
Overview 


\section{Overview of the FY 2002 GPRA Metrics Process}

Pacific N orthwest National Laboratory estimated the FY 2002 energy, environmental, and financial benefits (i.e., metrics) of the technologies and practices in the U.S. Department of Energy's (DOE's) Office of Building Technology, State and Community Programs (BTS). BTS falls within DOE's Office of Energy Efficiency and Renewable Energy (EE), which uses the estimates of benefits as part of its annual budget request.

The metrics effort was initiated by EE in 1994 to develop quantitative measures of program benefits and costs. The Government Performance and Results Act (GPRA) of 1993 mandates such estimates of benefits, which are submitted to EE's Office of Planning, Budget, and Management (OPBM) as part of EE's budget request. The supporting analysis and data are used to set strategic goals and objectives within BTS and DOE, to communicate the benefits of EE programs to all interested parties, and to defend the budget before OPMB and Congress.

\section{Estimating the Energy Savings of BTS Programs}

Energy savings for the FY 2002 GPRA metrics were based on the FY 2002 budget appropriation and estimated at a program level and then aggregated to the decision unit level. Benefits were estimated for 36 BTS programs and then rolled up into 19 programs and the 8 BTS decision units, as shown in Table 1. BTS's eight decision units fall into one of two broad areas:

- Building Research and Standards, which develops, implements, and coordinates research and development $(R \& D)$ that improves the energy efficiency of building components and then uses system design and regulatory activities to integrate these components into building energy systems. ${ }^{1}$

- Building Technology Assistance, which is responsible for accelerating the adoption of energy efficiency and renewable building technologies through technical and financial assistance to states and local communities. ${ }^{2}$

Several different approaches are required to estimate the benefits of the wide array of BTS programs. This section briefly describes the analytical approaches used to estimate energy savings for the FY 2002 appropriated budget for BTS. Greater detail on each BTS program is provided later in this document in program-specific summaries.

The benefits of EE programs and technologies were assessed at an aggregated level as decision units (formerly known as planning units) to simplify cross-sector comparisons and to limit the number of elements being evaluated to a manageable number. Likewise, the benefits were assessed for a limited number of defined metrics:

- energy savings

- environmental benefits

- economic/financial metrics.

1 "BTS Building Research and Standards Measurement Statement," FY 2002 Budget Request (internal BTS document).

2 “BTS Office of Building Technology Assistance Mission Statement," FY 2002 Budget Request (internal BTS document). 
Table 1. Decision Units and Programs Evaluated for FY 2002 GPRA Metrics

\begin{tabular}{|c|c|c|}
\hline Decision Unit & 36 BTS Activities or Technologies & $\begin{array}{l}\text { 19 BTS Programs Aggregated } \\
\text { for GPRA FY } 2002 \text { Metrics }\end{array}$ \\
\hline StateEnergy & - State Formula Grants & - State Formula Grants \\
\hline $\begin{array}{l}\text { Weatherization } \\
\text { Assistance }\end{array}$ & - Weatherization Assistance Program & $\begin{array}{l}\text { - Weatherization Assistance } \\
\text { Program }\end{array}$ \\
\hline $\begin{array}{l}\text { Community E nergy } \\
\text { Program }\end{array}$ & $\begin{array}{l}\text { - Rebuild America/E nergy Smart Schools } \\
\text { - Information Outreach } \\
\text { - Training \& Assistance for Codes }\end{array}$ & $\begin{array}{l}\text { - Rebuild America/E nergy Smart } \\
\text { Schools' } \\
\text { - Information Outreach } \\
\text { - Training and Assistance for } \\
\text { Codes }\end{array}$ \\
\hline Energy Star Program & $\begin{array}{l}\text { - Energy Star: Clothes Washers } \\
\text { - Energy Star: Refrigerators } \\
\text { - Energy Star: Electric Water Heaters } \\
\text { - Energy Star: Gas Water Heaters } \\
\text { - Energy Star: Room Air Conditioner } \\
\text { - Energy Star: Compact Fluorescent Lights } \\
\text { - Energy Star: Dishwashers }\end{array}$ & - Energy Star \\
\hline $\begin{array}{l}\text { Technology Roadmaps } \\
\text { and Competitive R\&D }\end{array}$ & - Technology Roadmaps and Competitive R\&D & - Competitive $R \& D$ \\
\hline $\begin{array}{l}\text { Residential Buildings } \\
\text { Integration }\end{array}$ & $\begin{array}{l}\text { - Residential Buildings R\&D } \\
\text { - Residential Building Codes }\end{array}$ & $\begin{array}{l}\text { - Residential Buildings R\&D } \\
\text { - Residential Building Codes }\end{array}$ \\
\hline $\begin{array}{l}\text { Commercial Buildings } \\
\text { Integration }\end{array}$ & $\begin{array}{l}\text { - Commercial Buildings R\&D } \\
\text { - Commercial Building Codes }\end{array}$ & $\begin{array}{l}\text { - Commercial Buildings R\&D } \\
\text { - Commercial Building Codes }\end{array}$ \\
\hline $\begin{array}{l}\text { Equipment, Materials, } \\
\text { and Tools }\end{array}$ & 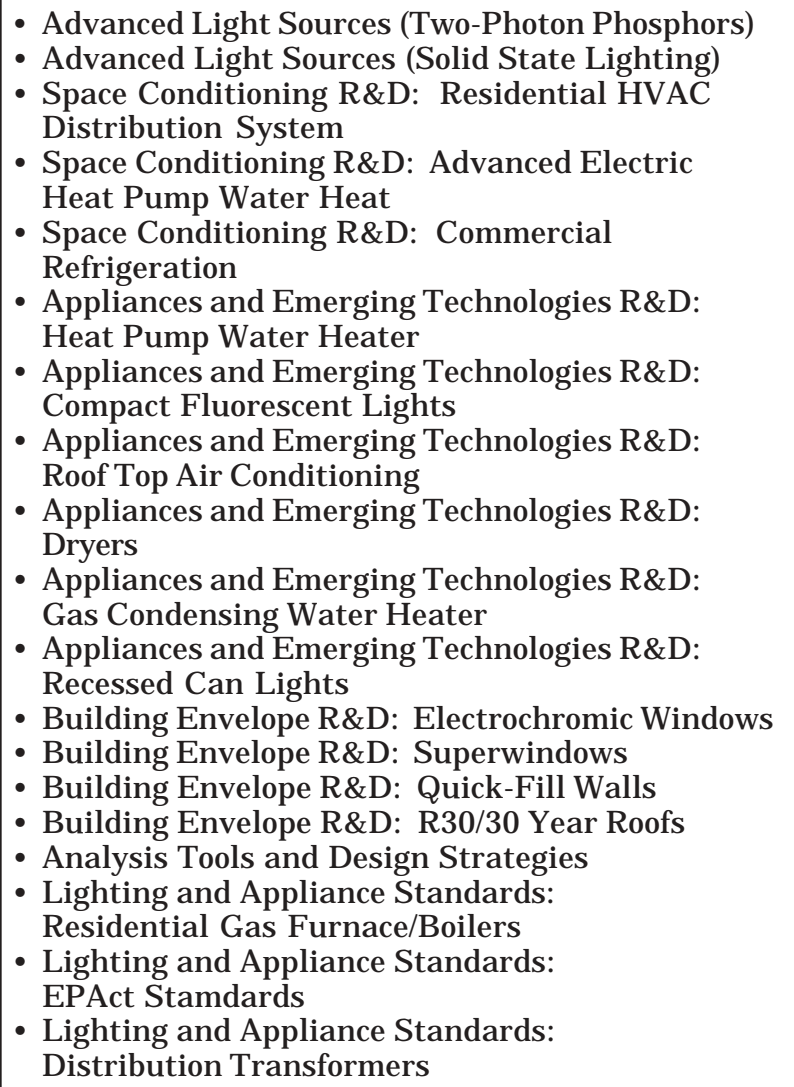 & $\begin{array}{l}\text { - Lighting R\&D } \\
\text { - Space Conditioning and } \\
\text { Refrigeration R\&D } \\
\text { - Appliances and Emerging } \\
\text { Technologies R\&D } \\
\text { - Building Envel ope R\&D: } \\
\text { E lectrochromicWindows } \\
\text { - Building Envel ope R\&D: } \\
\text { Superwindows } \\
\text { - Building Envel ope R\&D: Thermal } \\
\text { Insulation and Building Materials } \\
\text { - Analysis Tools and Design } \\
\text { Strategies } \\
\text { - Lighting and Appliances } \\
\text { Standards }\end{array}$ \\
\hline
\end{tabular}


Environmental and economic benefits (energy cost savings) were keyed directly to energy savings. Therefore, the balance of this overview focuses on just the energy-savings' estimates.

For most of the BTS programs for which estimates were developed, the benefits estimates are broken out by building sector, building type, region, vintage, end use, fuel type, and type of equipment displaced and then aggregated to obtain the benefits for a program or technology. The program and decision unit structure used in this document reflected the structure used in the FY 2002 budget request.

The analysis considered program goals, technol ogy characteristics (including performance and cost), the targeted market, and program milestones. The technologies and practices model ed were chosen as representing a specific program. Not all activities funded by BTS are modeled; activities were selected if they met some minimal threshold of funding and are likely to result in measurable energy savings.

The program characteristics were devel oped through extensive interaction with the BTS Office Directors and Program Managers. For FY 2002, program characterization summaries were based on information gathered during interviews conducted throughout the summer of 2000. The characterizations were then reviewed and revised during meetings with BTS Program Managers. The program characterizations presented in subsequent sections of this document represent the results of those interviews, reviews, and revisions.

\section{Modeling Methods Used In Estimating Benefits}

The BTS GPRA estimates of benefits were calculated using one of three methods:

- National Energy Modeling System (NEMS)

- Building Energy Savings Estimation Tool (BESET)

- Spreadsheets designed for a specific program.

NEMS allows the costs and benefit characteristics of a technology and its market penetration to be linked within NEMS. However, NEMS has difficulty representing some BTS technologies, such as the whole-building programs because NEMS is designed to model specific technologies and not variable groups of technologies.

BESET was built specifically for estimating the benefits of BTS programs and therefore allows various types of programs to be characterized, including whole-building, envelope, and equipment programs. The major disadvantage of BESET is that the penetration rates (i.e., fraction of sales or fraction of installed base) are determined outside the model and therefore are not explicitly linked to the program's cost and benefit characteristics. In addition, BESET cannot model BTS equipment that competes against more than one baseline equipment type.

For programs that are not easily model ed in BESET or NEMS, spreadsheets were used. For example, because BTS's codes and standards programs have already devel oped its own set of spreadsheet tools for estimating impacts of the building codes programs, these tools were adapted for the GPRA estimation process.

Each of the three methods used for deriving energy-saving estimates for the FY 2002 GPRA metrics is described in more detail in the following subsections. 


\section{NEMS}

NEMS is the primary midterm forecasting tool of the Energy Information Administration (EIA), used for the projections contained in EIA's Annual Energy Outlook (AEO) and numerous special studies for the U.S. Congress and DOE. NEMS consists of a series of computer simulation models that represent all the major energy supply, demand, and conversion sectors of the U.S. economy. NEMS represents domestic energy markets by explicitly representing the economic decision-making involved in the production, conversion, and consumption of energy products and, where possible, NEMS includes explicit representation of energy technologies and their characteristics.

Most of BTS's technology programs are modeled using NEMS. The commercial and residential energy demand modulles within NEMS were used to calculate the savings generated by the improved BTS technologies. Energy savings in equipment programs were calculated by comparing new equipment efficiencies with baseline efficiencies. ${ }^{3}$

The NEMS commercial and residential demand modules generate forecasts of energy demand (energy consumption) for those sectors. The commercial demand module generates fuel consumption forecasts for electricity, natural gas, and distillate fuel oil. These forecasts are based on energy prices and macroeconomic variables from the NEMS system, combined with external data sources. The residential model uses energy prices and macroeconomic indicators to generate energy consumption by fuel type and census division in the residential sector.

NEMS selects specific technologies to meet the energy services demands by choosing among a discrete set of technologies that are exogenously characterized by commercial availability, capital costs, operating and maintenance costs, efficiencies, and lifetime (see Figure 1). NEMS is coded to allow several possible assumptions to be used about consumer behavior to model this selection process. For the GPRA effort, the menu of equipment was changed to include relevant BTS program equipment, technological innovations, and standards.

The NEMS design can accommodate various technology choices. F or the GPRA FY 2002 metrics, the NEMS data input was adjusted to reflect BTS technology choices. For BTS programs that target shell efficiency, specific shell-efficiency indices were read into the model. The commercial and residential demand modules in NEMS are summarized bel ow.

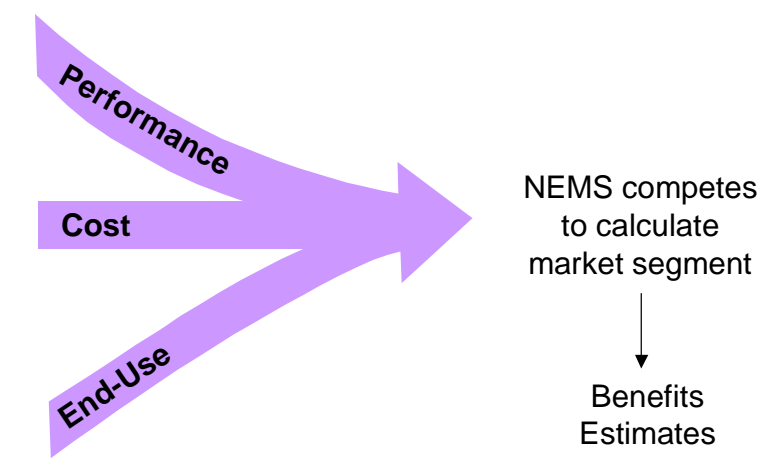

Figure 1. Developing the Market Segment (NEMS)

${ }^{3}$ The FY 2002 metrics used the NEMS model associated with the Energy I nformation Administration's Annual Energy Outl ook 2000. 


\section{BESET}

BESET is a bottom-up accounting model that compares baseline energy use against the BTS technology. BESET also is used to centrally collect, store, and report all results produced by all the various estimation methods. Finally, BESET produces the input files needed for estimating employment impacts developed in a separate modeling environment.

BESET can estimate benefits for various programs: whole building, envelope, lighting, HVAC, cogeneration, and water heating. BESET also contains a "tax" algorithm that calculates the average energy savings per budget dollar for the BTS portfolio so the energy savings can be applied to an umbrella program. Beginning with the FY 2001 GPRA effort, BESET was primarily used to model BTS programs that target whole-building energy use. Although BESET can model equipment and envelope programs, those programs are estimated by NEMS.

To determine energy savings for specific BTS programs, BESET requires information in the following areas:

- Program Performance Goals. The goals of each program are assessed in terms of energy savings (e.g., percent load reductions and equipment efficiency improvements) and used as inputs to BESET.

- Target Market. Target markets are defined in terms of building sector (e.g. residential and commercial), building type (e.g. single family and commercial education), size (commercial only), income level (residential only), vintage (e.g., new or existing), and climate zone or region. Using the Rebuild America program as an example, Figure 2 illustrates the process used to define the program's targeted market segment within BESET.

Once the target market has been identified, the penetration into that market is deter-

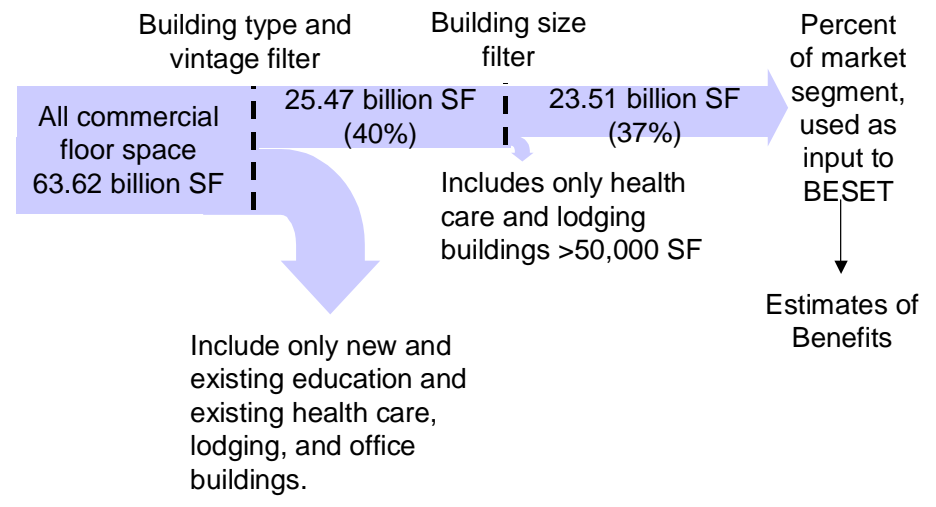

Figure 2. Developing the Market Segment (NEMS): Rebuild America Example

mined using technology diffusion curves (discussed later in this section). Within BESET, market penetration is defined as either the fraction of sales for equipment for new buildings or the fraction of installed base for existing buildings. The penetration model requires only the year of introduction into the market, an estimate of market penetration in 2020 (provided by BTS Program Managers), and the selection of the most appropriate diffusion curve category. 
- Private Investment (Cost). Estimates of private investment for both the baseline and the BTS technology or practice are entered into BESET. I deally, the investment costs would be considered when market penetration is developed; however, the current diffusion model used does not incorporate costs at this time. In addition to private investment, non-energy savings program benefits are also quantified when possible and entered into BESET.

The basic steps involved in calculating the energy savings for whole-building programs modeled in BESET are as follows:

1. Determine the size of the potential market.

2. Determine the number of units affected by the BTS program.

3. Determine the base space conditioning, water heating and other end-use loads if appropriate.

4. Determine the space conditioning and water heating end-use loads after the program is implemented.

5. Calculate the energy savings.

All estimates were aggregated through a BESET-NEMS interface. BESET contains a report generator that aggregates the program and technology level benefits into the decision units. The aggregated information is submitted to OPBM to include in the GPRA metrics effort for all EE sectors.

\section{Spreadsheet Models}

Whenever possible, programs were modeled within NEMS or BESET to help ensure consistency in basel ine inputs and methodology. However, several BTS programs were modeled in spreadsheets because of their unique characteristics. The estimated savings generated by the spreadsheet models were entered by fuel type into "fixed" tables within BESET so that the environmental and energy cost-savings' benefits can be calculated using the same data set as the other programs. Spreadsheets were used to model the following programs:

- State Formula Grants. This program was modeled based on historical information that provides an estimated level of savings per program dollar. Because neither BESET nor NEMS are designed for this type of analysis, the program continued to be modeled in a separate spreadsheet.

- Weatherization Assistance Program. This program was modeled based on program studies that provide per-household savings' estimates. While these inputs may be able to be translated into load reductions and the program run through BESET, such an effort has not been undertaken. The primary barrier to incorporating this program into BESET is that fuel mix for houses in the target market is significantly different between the BESET baseline and historical Weatherization program data.

- Information Outreach. The estimates for the FY 2002 request and appropriation were adopted directly from a study commissioned by BTS. ${ }^{4}$

\footnotetext{
${ }^{4}$ Messersmith, J . and S.A. Azimi. August 2000. Communi cation Effectiveness Analysis for GPRA.
} Technologists, Inc. 
- Building Codes. Building code activities are spread among three BTS decision units. However, because of the interrelationships between the three, savings were estimated for the building codes and standards as a whole. Savings estimates were then allocated among the three primary funding sources:

- Training and Assistance for Codes (within the Community Energy Program decision unit)

- Residential Energy Codes (within Residential Buildings I ntegration decision unit)

- Commercial Energy Codes (within Commercial Buildings Integration decision unit).

The long-term impact of DOE's assistance to code activities is based largely on data developed for internal use in building codes and standards. DOE provides a high level of support for states seeking to adopt new energy codes, either based on ASHRAE Standard 90.1 or the International Energy Conservation Code (previously the Model Energy Code). Several states have self-developed codes that are not supported by building codes and standards and are not counted in the estimates of program impact.

- Competitive R\&D. Estimates were based on savings estimates developed by the winners of the FY 1999 Competitive R\&D bidding process.

- Appliances and Emerging Technologies R\&D. While some technologies within this program were modeled in NEMS, three of the technologies contained either performance or program characteristics that made them difficult to model in NEMS or BESET:

- Compact fluorescent lights - The compact fluorescent light program had very specific sales targets for a short (three years) period of time, so a spreadsheet estimation was required.

- Rooftop air conditioning - This program had goals of 10\% efficiency improvements applied to $10 \%$ of sales. Because of the wide range of commercial rooftop air-conditioning equipment efficiencies and the specific sales goal, the program was modeled in a spreadsheet.

- Recessed can lights - This program includes lighting technologies that are not specifically called out in either NEMS or BESET so was modeled in a spreadsheet.

- Space Conditioning R\&D: Refrigeration. The refrigeration savings estimates were based on a report on end-use consumption produced by PNNL, program goals, and other various data sources (Belzer and Wrench 1997). Energy-savings estimates were developed in a spreadsheet model because commercial refrigeration is a service, not a specific piece of equipment, and therefore cannot be modeled in NEMS or BESET.

- Lighting and Appliance Standards: Distribution Transformers. Distribution transformers are part of the el ectricity distribution system, not the building system. Therefore, transformers cannot be modeled in either NEMS or BESET. Savings estimates for a distribution transformer standard were based on a study by Geller and Nadel (1992).

\section{Baseline Inputs}

To the extent possible, the underlying assumptions about building stock forecasts, equipment efficiencies, market shares, and end-use loads were consistent across tools (i.e., NEMS, BESET, and spreadsheets). This consistency was accomplished by drawing most of the baseline character- 
ization data from the Energy Information Administration (EIA), a statistical agency within DOE. For example, the same version of NEMS used in this document was used to produce EIA's Annual Energy Outlook (2000).

For programs modeled in NEMS, consistency is ensured not only across these programs but also with EIA forecasts. BESET also has a baseline characterization, which is drawn from NEMS, EIA's Annual Energy Outlook, the "Residential Energy Consumption Survey," and the "Commercial Buildings Energy Consumption Survey." The consistency of the baseline assumptions of the spreadsheet tools is verified against EIA's data.

\section{Budget Adjustment Process}

The program characterizations that are key to the benefits' estimates are developed through dose interaction with the BTS Program Managers. The characterizations require the Program Manager to make assumptions based on the requested level of funding, and the characterization then describes what would be accomplished at that level. However, the budget request amount sometimes changes between the time the characterization is developed and the time the benefits estimates are required. Changes also occur between the final budget request (on which the final estimates are based) and the actual allocation (for which benefits estimates have also been developed to assist in planning).

For small changes in budget levels, a basic "budget adjustment" is made to the program estimates. It is assumed that to get to $X$ savings, a total of $Y$ budget must be spent, where $Y$ is the cumulative budget. A change in the annual budget results in a change in the cumulative budget. Revised savings are calculated for each year as old savings in year z (new cumulative budget in year z/old cumulative budget in year $z$ ). This adjustment mechanism implicitly suggests that either the fraction of expected sales or the performance of the program has changed but does not explicitly tie the change to one factor or the other.

For larger changes, the program inputs are revisited with the BTS Program Managers to determine the impact of a reduced (or increased) budget. Options include changing the year of market introduction, changing the impact on sales (market penetration), modifying the performance objective, and adding or removing tasks or technologies within the program (e.g., increased funding in Energy Star may result in developing an Energy Star rating for an additional technology).

The set of energy-savings' estimates documented in this report was produced based on the appropriations by Congress for FY 2002. Several programs had to be re-evaluated when the funding level changed significantly. Therefore, the initial estimates had to be re-estimated.

\section{Technology Diffusion Curves}

In 1998, a study was conducted by David Belzer, PNNL, to examine the historical market penetration (i.e., diffusion) for 10 energy-efficient products related to the building sector. Diffusion models were estimated for each product based on the specification proposed by Frank Bass in the late 1960s. The resulting models were incorporated into the GPRA metrics analysis for many of the programs and technologies not modeled within the NEMS framework. The model development and empirical analysis were designed to generate more credible predictions of the adoption process of important energy-efficiency technologies in the buildings sector. 
The technologies were placed into four separate categories: lighting, HVAC and refrigeration (HVAC/R), envelope, and design. Two additional categories were added: 1) "Other Equipment" represents an average of lighting and HVAC/refrigeration technologies and 2) "Other Program" represents the envelope category. See Appendix C for a summary of this study.

\section{Contents of this Document}

The remainder of this report consists of 19 program descriptions, summarizing information about program's objective, long-term goals, and market and its savings in terms of primary energy savings, carbon equivalent reductions, and consumer cost savings.

Four appendixes provide more detailed information on topics covered in this document. Appendix A details the baseline scenario and inputs used for the FY 2002 metrics. Appendix B contains the GPRA Data Call for FY 2002. Appendix C provides more detailed information on the development of the technology diffusion curves. Appendix D provides detail on the methodology for the GPRA methodology.

\section{References}

Annual Energy Outlook 1995. 1995. Energy Information Administration.

Annual Energy Outl ook 2000. 1999. Energy Information Administration.

Appliance Magazine. 1998. “Life Expectancy/Replacement Picture,” 55(9):71.

ASHRAE Standard 90a-1980, "Energy Efficient Design of New Buildings Except New Low-Rise Residential Buildings," American Society of Heating, Refrigeration, and Air-Conditioning Engineers.

ASHRAE Standard 90.1-1989, “E nergy Efficient Design of New Buildings Except New Low-Rise Residential Buildings," American Society of Heating, Refrigeration, and Air-Conditioning Engineers.

ASHRAE Standard 90.1-1999, “Energy Standard for Buildings Except Low-Rise Residential Buildings," American Society of Heating, Refrigeration, and Air-Conditioning Engineers.

Belzer, D.B and L.E. Wrench. 1997. End-Use Consumption Estimates for U.S. Commercial Buildings, 1992. PNNL-11514, Pacific Northwest National Laboratory.

Berry, L.G., M.A. Brown, and L.F. Kinney, 1997, Progress Report of the National Weatherization Assistance Program, ORNL/CON-450, Oak Ridge National Laboratory.

Brown, M.A., L.G. Bery, R.A. Balzer, E. Faby. 1993. National Impacts of the Weatherization Assistance Program in Single-Family and Small Multifamily Dwellings. ORNL/CON-326, Oak Ridge National Laboratory.

BTS Core Data Book (internal BTS document), 1999. http://www.btscoredatabook.net

"BTS Building Research and Standards Mission Statement," FY 2002 Budget Request, U.S. Department of Energy, Office of Building Technology, State and Community Programs. 
"BTS Office of Building Technology Assistance Mission Statement," FY 2002 Budget Request, U.S. Department of Energy, Office of Building Technology, State and Community Programs.

“Building Technology, State and Community Programs F unding Profile for the FY 2002," (internal BTS document).

"Case for a National Research Program on Semiconductor Lighting," Roland Haitz and Fred Kish, Hewlitt-Packard Co.; J eff Tsao and J eff N elson, Sandia National Laboratories. White paper presented at the 1999 Optoelectronics Industry Development Association forum in Washington D.C., October 6, 1999.

"Commercial Buildings Energy Consumption Survey." Latest Edition. U.S. Department of Energy, Energy Information Administration. eia.doc.gov/emeu/cbecs/contents.html

Corporate Review Budget (internal BTS document).

Energy Policy Act of 1992, Public Law 102-486

FY 2001 GPRA Program Characterization (internal BTS document).

Geller, H. and S. Nadel. 1992. "Consensus National Efficiency Standards for Lamps, Motors, Showerheads and Faucets, and Commercial HVAC Equipment." In 1992 America for an EnergyEfficient E conomy Proceedings, 6.71-6.82.

Government Performance and Results Act of 1993.

Messersmith, J ., and S.A. Azim. August 2000. Communication Effectiveness Analysis for GPRA, Technologists, Inc.

National Appliance Energy Conservation Act of 1987 P.L. 100-12

"Residential Energy Consumption Survey." Latest Edition. U.S. Department of Energy, Energy Information Administration. eia.doc.gov/emeu/recs/contents.html

U.S. Department of Energy, Office of Building Technology, State and Community Programs (internal documents) FY 2002 Budget Requests:

Data Bucket Report for Analysis Tools and Design Strategies Program

Data Bucket Report for Appliances and Emerging Technology Program

Data Bucket Report for Building Envelope: Thermal Insulation and Building Materials Program

Data Bucket Report for Building Envelope: Windows Program

Data Bucket Report for Commercial Building Codes Program

Data Bucket Report for Commercial Building Integration R\&D Program

Data Bucket Report for Energy Star Program

Data Bucket Report for I nformation Outreach Program

Data Bucket Report for Lighting and Appliance Standards Program

Data Bucket Report for Lighting R\&D Program

Data Bucket Report for Rebuild America Program

Data Bucket Report for Residential Building Integration R\&D Program

Data Bucket Report for Space Conditioning and Refrigeration: Refrigeration Program

Overview - 10 
Data Bucket Report for State Formula Grants Program

Data Bucket Report for Technology Roadmaps and New and Innovative R\&D

Data Bucket Report for Weatherization Assistance Program

Data Bucket Report for Residential Building Codes Program

\section{List of Terms}

$\begin{array}{ll}\text { BESET } & \text { Building Energy Savings Estimation Tool } \\ \text { BTS } & \text { Office of Building Technology, State and Community Programs } \\ \text { CBECS } & \text { Commercial Buildings Energy Consumption Survey } \\ \text { DOE } & \text { U.S. Department of Energy } \\ \text { EE } & \text { DOE's Office of Energy Efficiency and Renewable Energy } \\ \text { EER } & \text { energy efficiency ratio } \\ \text { EIA } & \text { Energy Information Administration } \\ \text { EPACt } & \text { Energy Policy Act } \\ \text { EPACt } & \text { Energy Policy Act of 1992 } \\ \text { EREC } & \text { Energy Efficiency and Renewable Energy Clearinghouse } \\ \text { GPRA } & \text { Government Performance and Results Act of 1993 } \\ \text { IEEC } & \text { International Energy Conservation Code } \\ \text { NEMS } & \text { National Energy Modeling System } \\ \text { OPBM } & \text { Office of Planning, Budget, and Management } \\ \text { ORNL } & \text { Oak Ridge National Laboratory } \\ \text { PNNL } & \text { Pacific Northwest National Laboratory } \\ \text { R\&D } & \text { research and development } \\ \text { RECS } & \text { Residential Energy Consumption Survey } \\ \text { SEER } & \text { seasonal energy efficiency ratio }\end{array}$




\section{Summary of Benefits}




\section{BTS Primary Energy Savings Forecasts Based on FY 2002 BTS Budget Appropriation}

The results of the forecasted energy savings, consumer cost savings, and carbon benefits for each of the 19 BTS programs (for 2002, 2010, and 2020) are included in the program summaries in the next section. Tables that include forecasted benefits up to the year 2030 for all programs and decision units are included in a separate document, which is available upon request. The benefit estimates available in that document include the following:

Energy Savings Benefits Tables (TBtu per year)

Total Primary Energy Savings

Primary Electricity savings

Primary Non-Electric Savings

Site Electricity Savings

Site Natural Gas Savings

Site Oil Savings

Environmental Benefits Tables (million metric tons per year)

Carbon Equivalent Emissions Reductions

$\mathrm{SO}_{2}$ Emissions Reductions

$\mathrm{NO}_{\mathrm{X}}$ Emissions Reductions

CO Emissions Reductions

PM Emissions Reductions

VOC Emissions Reductions

Financial Benefits Tables (million \$ per year)

Consumer Cost Savings

Non-Energy Cost Savings

Incremental Private Investment

\section{Energy Savings Analysis by Decision Unit}

Decision unit benefits are reported annually. The energy savings estimates for 2010 represent energy saved in 2010 only. These are not cumulative benefits estimates. Note, however, that the energy savings in 2010 are a function of all program activities from FY 2002 on, so the number of affected buildings is a cumulative value. For example, the energy saved in 2010 from the compact fluorescent lights programs is the energy saved in 2010 only from all buildings that have had such lights installed any time between FY 2002 and FY2010.

Total primary energy savings for all BTS programs are estimated to reach 1.2 quadrillion Btu (QBtu) by year 2010 and 2.9 QBtu by year 2020. Figure 1 charts annual energy savings for all programs for all years from FY 2002 to 2020.

Of all BTS energy savings (in year 2020), 41\% are generated by programs included in the Equipment, Materials, and Tools decision unit (see Figure 2). This decision unit targets efficiency improvements for specific heating, cooling, and lighting equipment as well as shell (e.g., windows, roofs and insulation) efficiency improvements, including standards that impact specific equipment. Equipment, Materials, and Tools makes up about $10 \%$ of the overall 


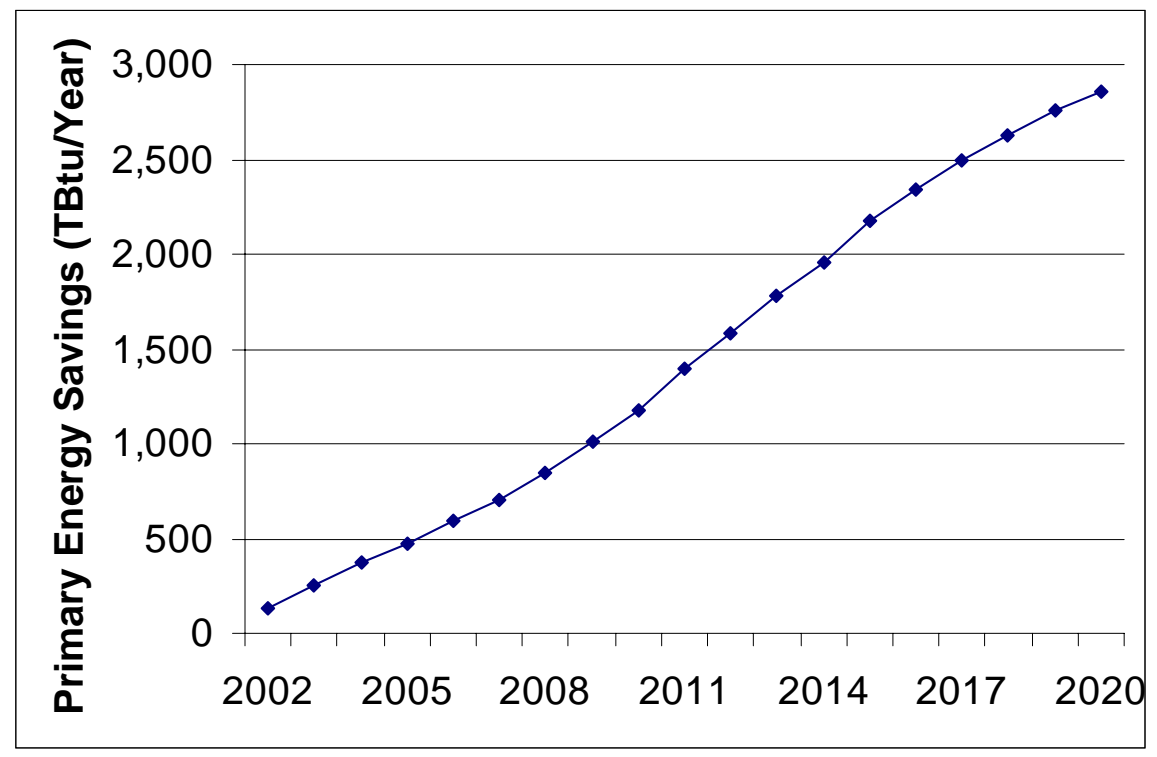

Figure 1. Total BTS Program Primary Energy Savings through FY 2020

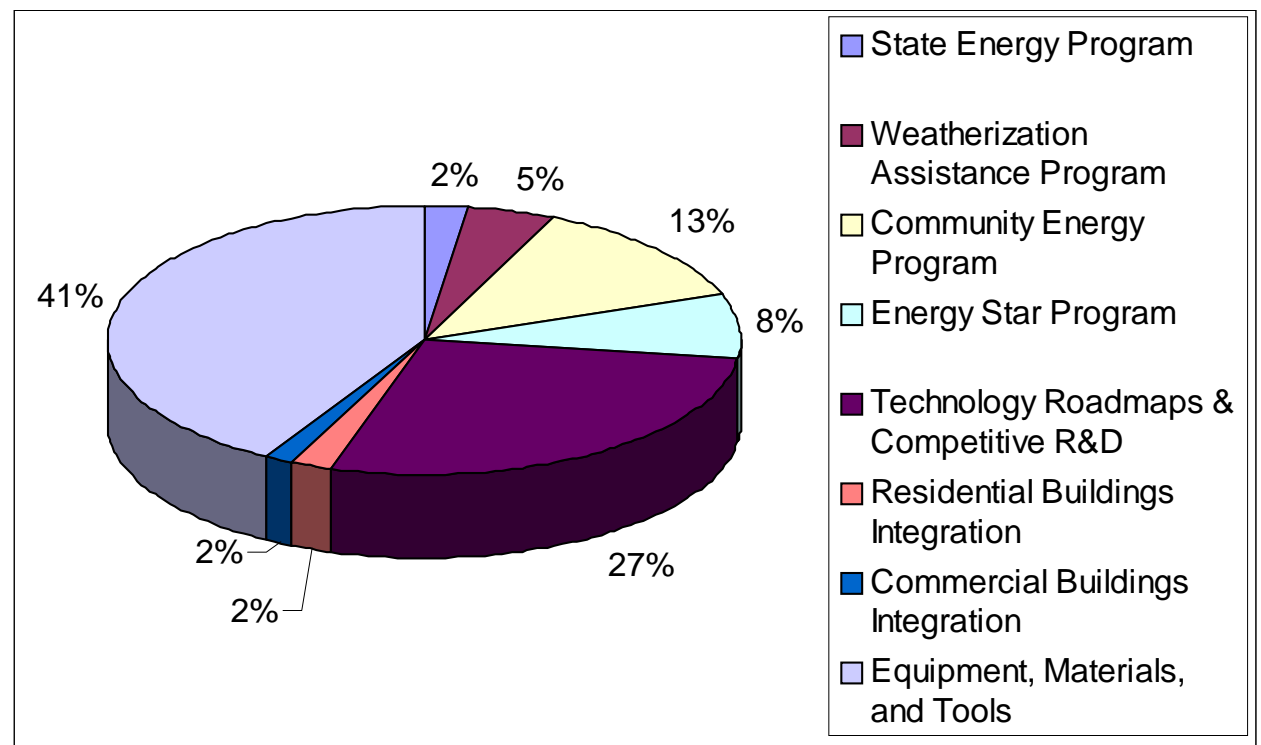

Figure 2. Primary Energy Savings by Decision Unit (for FY 2020)

BTS program FY 2002 budget. Technology Roadmaps and Competitive R\&D savings make up $27 \%$ of the overall primary energy savings in 2020 . While the budget for this program is just $2 \%$ of the overall FY 2002 BTS program budget, the competitive procurement funding is provided to industrial partners developing technologies that are close to commercialization. Programs that support the Community Energy Program make up an additional $13 \%$ of the overall BTS savings (in year 2020). Community Energy Programs include a combination of programs that target whole-building energy use primarily by providing outreach, education, training and tools, and partnership assistance. Community Energy Programs make up 5\% of the overall BTS FY 2002 budget. 
In terms of energy savings per budget dollar, the building codes programs and Competitive $R \& D$ have relatively high ratios of savings to budget dollar. The building codes programs benefit from having high penetration rates because these standards become regulatory mandates when adopted by states. Competitive $R \& D$ has a relatively high level of energy savings per budget dollar because it is a cost-sharing program, where DOE financially collaborates with private sector partners to target particular R\&D needs. Programs such as Weatherization and State Energy Programs tend to have relatively low ratios of savings to budget dollar because these programs provide grants and assistance directly to states and households. Figure 3 charts the FY 2002 budget dollars and the energy savings of each decision unit.

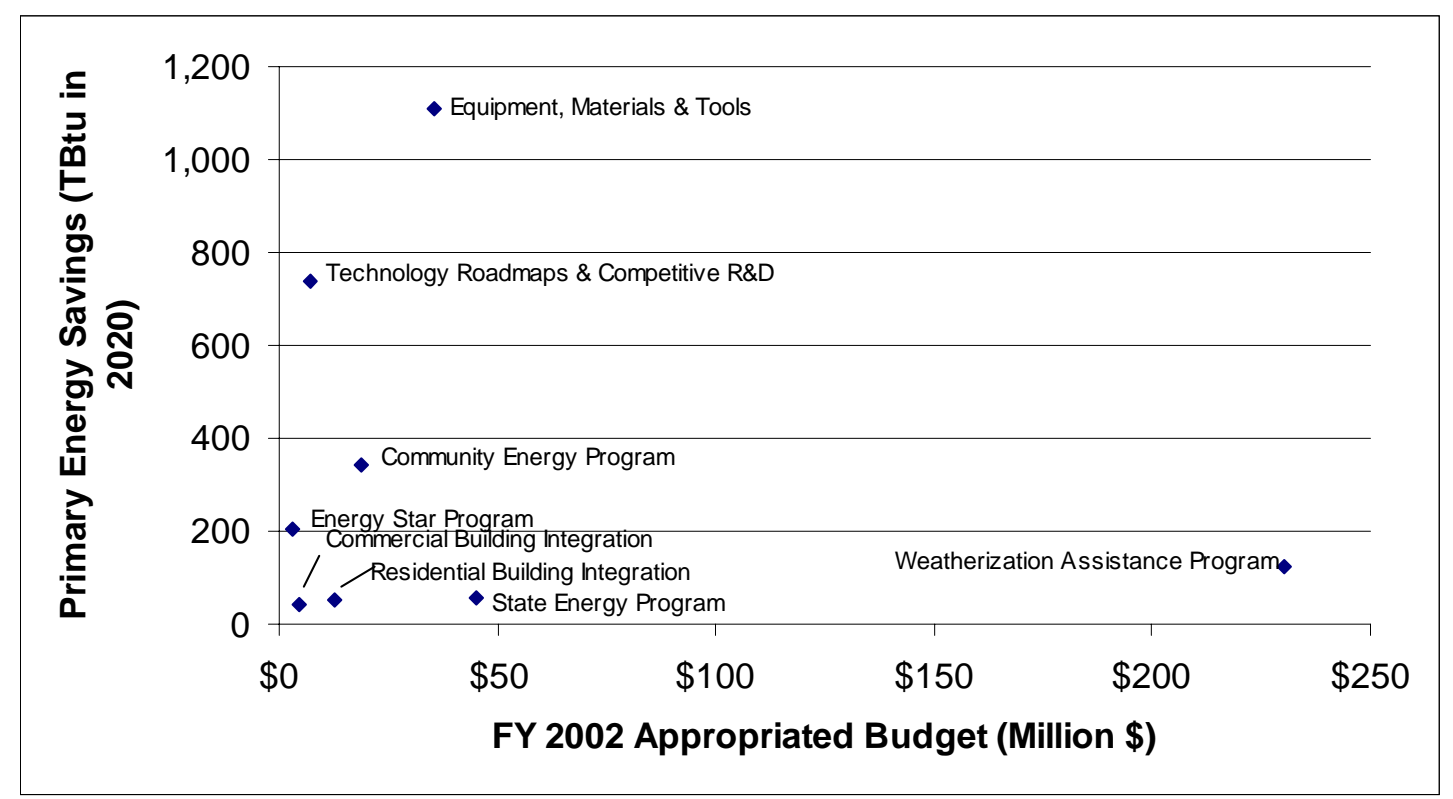

Figure 3. Budget and Energy Savings Scatter Plot for BTS Decision Units

\section{Summary of Benefits}

Table 1 summarizes the primary energy savings, the carbon equivalent reductions, and the consumer cost savings for the eight BTS decision units. 
Table 1. Summary of Benefits: Analyses of BTS Programs

\begin{tabular}{|c|c|c|c|c|c|}
\hline Decision Unit & $\begin{array}{c}\text { FY } 2002 \\
\text { Budget } \\
\text { (million \$) }\end{array}$ & 2002 & 2005 & 2010 & 2020 \\
\hline & \multicolumn{5}{|c|}{ Primary Energy Savings (Tbtu/Yr) } \\
\hline State Energy Program & 45 & 4.7 & 17.8 & 35.1 & 56.0 \\
\hline Weatherization Assistance Program & 230 & 7.4 & 32.4 & 71.1 & 122.2 \\
\hline Community Energy Program & 19 & 49.8 & 163.7 & 218.8 & 341.6 \\
\hline Energy Star Program & 3 & 42.5 & 120.1 & 199.8 & 206.0 \\
\hline $\begin{array}{l}\text { Technology Roadmaps and } \\
\text { Competitive } R \& D\end{array}$ & 7 & 11.7 & 76.1 & 322.0 & 735.9 \\
\hline Residential Buildings Integration & 12 & 0.3 & 2.3 & 17.2 & 52.5 \\
\hline Commercial Buildings Integration & 4 & 0.3 & 3.5 & 9.6 & 40.7 \\
\hline Equipment, Materials, and Tools & 35 & 13.4 & 57.2 & 282.8 & 1110.3 \\
\hline \multirow[t]{2}{*}{ Totals } & & 130.1 & 473.2 & 1157.0 & 2665.1 \\
\hline & \multicolumn{5}{|c|}{ Carbon Equivalent Emission Reductions (MMTC/Yr) } \\
\hline State Energy Program & 45 & 0.1 & 0.3 & 0.6 & 1.0 \\
\hline Weatherization Assistance Program & 230 & 0.1 & 0.5 & 1.2 & 2.0 \\
\hline Community Energy Program & 19 & 0.9 & 2.9 & 3.7 & 6.0 \\
\hline Energy Star Program & 3 & 0.8 & 2.2 & 3.4 & 3.6 \\
\hline $\begin{array}{l}\text { Technology Roadmaps and } \\
\text { Competitive R\&D }\end{array}$ & 7 & 0.2 & 1.4 & 5.4 & 13.1 \\
\hline Residential Buildings I ntegration & 12 & 0.0 & 0.0 & 0.3 & 0.8 \\
\hline Commercial Buildings Integration & 4 & 0.0 & 0.1 & 0.2 & 0.7 \\
\hline Equipment, Materials, and Tools & 35 & 0.3 & 1.0 & 4.7 & 19.2 \\
\hline \multirow[t]{2}{*}{ Totals } & & 2.4 & 8.5 & 19.4 & 46.5 \\
\hline & \multicolumn{5}{|c|}{ Consumer Cost Savings (million $\$ / y r$ ) } \\
\hline State Energy Program & 45 & 28.4 & 111.1 & 246.3 & 406.3 \\
\hline Weatherization Assistance Program & 230 & 51.0 & 226.8 & 523.8 & 891.9 \\
\hline Community Energy Program & 19 & 307.1 & 1047.6 & 1627.5 & 2671.5 \\
\hline Energy Star Program & 3 & 291.9 & 871.8 & 1731.7 & 1836.2 \\
\hline $\begin{array}{l}\text { Technology Roadmaps and } \\
\text { Competitive } R \& D\end{array}$ & 7 & 75.4 & 511.1 & 2544.5 & 6074.3 \\
\hline Residential Buildings I ntegration & 12 & 1.7 & 16.3 & 130.2 & 400.5 \\
\hline Commercial Buildings I ntegration & 4 & 1.9 & 22.6 & 69.5 & 306.4 \\
\hline Equipment, Materials, and Tools & 35 & 87.0 & 384.6 & 2146.5 & 8615.2 \\
\hline Totals & & 844.4 & 3192.0 & 9020.1 & 21202.2 \\
\hline
\end{tabular}


State Energy 


\section{Program Objective:(1)}

The State Formula Grants program emphasizes outreach, technology deployment, and forming partnerships to accomplish energy efficiency and renewable energy projects at the state and local level. The program supports the federal/state partnerships that are crucial to developing energy policies and deploying energy technology. The program provides a supportive framework with sufficient flexibility to allow states to address their energy priorities in concert with national priorities.

\section{Long-Term Goal:(1)}

The program's strategic plan for the $21^{\text {st }}$ century establishes three key goals to be accomplished by 2010:

1) maximize energy, environmental, and economic benefits through increased collaboration at the federal, state and community level; 2) increase market acceptance of energy efficiency and renewable energy technologies, practices, and products; and 3) use innovative approaches to reach market segments and meet policy goals not typically addressed by market-based solutions.

\section{Market Segment:}

\section{Target Market}

- Market Description: All markets (including buildings, transportation, industry, and power technologies) except new construction and all categories of energy end use.

\section{Methodology}

For the GPRA metrics, the State Formula Grants program is characterized based on an estimated level of savings per budget dollar, budget request, and leveraged funds. The basic assumptions are derived from a spreadsheet provided by the program in FY 1999. The assumptions were revised slightly because of external peer review by A.D. Little. The revisions are outlined in the sections below.

\section{Estimated Savings Per Budget Dollar:}

For the FY 2001 metrics, each program dollar was assumed to yield $0.0063 \mathrm{MBtu}$ of delivered electricity savings and $0.012 \mathrm{MBtu}$ of other fuel savings per year. These figures are based on an historical review of program savings from 1987-1993, as provided in the pro-

\section{State Formula Grants}

Program Type:

Grant

Target Market:

All sectors in all climate zones

\section{End Uses:}

All end uses, all fuel types

Unit of Measurement:

Energy savings per budget dollar

Modeling Tool:

Spreadsheet

Program Manager:

Faith Lambert

Website:

http://www.eren.doe.gov/

buildings/state_energy/

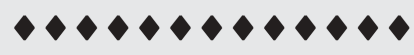

FY 2002 Benefits

Primary Energy Savings (TBtu)

\begin{tabular}{llll}
2002 & 2005 & 2010 & 2020 \\
\hline 4.7 & 17.8 & 35.1 & 56.0
\end{tabular}

Carbon Equivalent Reductions (MMTCE)

\begin{tabular}{cccc}
2002 & 2005 & 2010 & 2020 \\
\hline .089 & .330 & .621 & 1.027
\end{tabular}

Consumer Cost Savings (million \$)

\begin{tabular}{llll}
2002 & 2005 & 2010 & 2020 \\
\hline 28 & 111 & 246 & 406
\end{tabular}




\section{State Formula Grants}

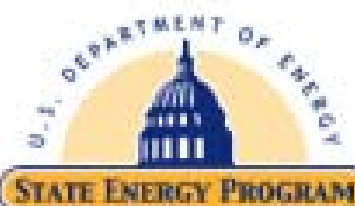

gram spreadsheet. To develop energy savings by fuel type for other fuel savings, a split of $75 \%$ natural gas and $25 \%$ fuel oil was assumed.

While this same level of savings was used initially for the FY 2002 effort, it was modified based on the A.D. Little peer review. Based on concerns about the historical versus future project mix, savings based on recycling and wood and biomass renewables were removed. These revisions resulted in an estimate of $0.0044 \mathrm{MBtu}$ of delivered electric savings and $0.0065 \mathrm{MBtu}$ of other fuel savings per program dollar per year. For FY 2002, the fuel split was modified to reflect historical information, yielding a split of $20 \%$ natural gas and $80 \%$ fuel oil. The savings also were split between the residential and commercial sectors (with the commercial sector representing savings from industrial, transportation, and utilities) based on the historical split of savings (7\% residential and 93\% nonresidential).

\section{Budget Request and Leveraged Funding:}

The estimated energy savings were calculated using the FY 2002 appropriated budget, the budget forecast for FY 2002 - FY 2030, and a leveraged funding forecast. Funds were assumed to be leveraged at a ratio of $\$ 4$ for every budget dollar. For FY 2002, the estimates were based on the appropriated budget of $\$ 45$ million, with future projections that this level of funding would remain constant through the analysis period.

\section{Non-Energy Benefits:}

Cleaner air and water, increased jobs, enhanced national security, increased economic competitiveness in world markets, and mitigation of global warming.(1)

\section{Program Strategy (\% of budget):}

- Research and Development - 0\%

- Market Transformation - 95\%

- Codes and Standards - 5\%.

\section{Sources:}

(1) FY 2002 Budget Request - Data Bucket Report for State Formula Grants Program (internal BTS document). 


\section{Weatherization Assistance}




\section{Weatherization Assistance Program}

\section{Program Objective:(1)}

The Weatherization Assistance Program provides costeffective energy-efficiency services to low-income constituencies who otherwise could not afford the investment and who would benefit significantly from the cost savings of energy-efficiency technologies. The program focuses on households that spend a disproportionate amount of their income for energy, giving priority to households with elderly members, persons with disabilities, and children.

In 1999 the Weatherization network of state and local agencies adopted a new strategic vision for the program called Weatherization Plus. The new strategy emphasizes a shift to the whole-house approach and includes electric baseload measures and incorporates advanced technologies. Within the new $\$ 2500$ legislative cap on average expenditure per household, the mix of measures will include those with enhanced impacts on greenhouse gas emissions and pollution reduction. Such measures include intensified building envelope and heating/cooling system measures, more health and safety measures (supporting other community goals), and more baseload uses such as water heating and lighting.

\section{Long-Term Goal:(1)}

The long-term goal of the Weatherization Assistance Program is to achieve $30 \%$ energy savings in 1.8 million or 3 million existing low-income homes by 2010, depending on future budget appropriations.

\section{Market Segment:}

\section{Target Market}

- Market Description:. Low-income homes and targets measures that include air sealing; caulking and weather stripping; furnace and boiler tuneup, repair, and replacement; cooling system tuneup and repair; replacement of windows and doors; addition of storm windows and doors; insulation of building shells; replacement of air conditioners; ceiling, attic, and whole-house fans; evaporative coolers; screening; and window films. ${ }^{(2)}$ Weatherization Plus would expand this strategy to include water heating, refrigeration, lighting, and cooling.(1)

- Size of Market: About 29 million eligible low-income homes.

\section{Weatherization Program}

\section{Program Type:}

Envelope/Grant

Target Market:

Low-income residential housing in all climate zones

\section{End Uses:}

All end uses, all fuel types

Unit of Measurement:

Energy-savings per budget dollar

Modeling Tool:

Spreadsheet

Program Manager:

Greg Reamy

Website:

http://www.eren.doe.gov/buildings/ weatherization_assistance/

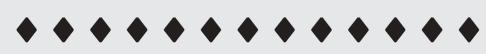

FY 2002 Benefits

Primary Energy Savings (TBtu)

\begin{tabular}{llll}
2002 & 2005 & 2010 & 2020 \\
\hline 7.4 & 32.4 & 71.7 & 122.2
\end{tabular}

Carbon Equivalent Reductions (MMTCE)

\begin{tabular}{cccc}
2002 & 2005 & 2010 & 2020 \\
\hline .125 & .537 & 1.161 & 2.002
\end{tabular}

Consumer Cost Savings (million \$)

\begin{tabular}{rrrr}
2002 & 2005 & 2010 & 2020 \\
\hline 51 & 227 & 524 & 892
\end{tabular}




\section{Weatherization Assistance Program}

Weatherization Assistance Program Decision Unit

\section{Methodology}

For the GPRA metrics, the Weatherization Assistance program is characterized based on an estimated level of savings per household, cost to weatherize each household, budget request, and leveraged funds and an assumed life expectancy of 15 years for weatherization measures. The basic assumptions are derived from a weatherization spreadsheet provided by the Weatherization program in September 2001.

\section{Estimated Savings Per Household:}

For FY 2002, the savings per household used for each region are shown in the table below.

\begin{tabular}{|l|c|c|}
\hline Region & $\begin{array}{c}\text { Regular } \\
\text { Household } \\
\text { Savings } \\
\text { (MMBtu/yr) }\end{array}$ & $\begin{array}{c}\text { Plus } \\
\text { Household } \\
\text { Savings } \\
\text { (MMBtu/yr) }\end{array}$ \\
\hline South & 22.25 & 24.23 \\
\hline Northeast & 31.20 & 46.04 \\
\hline West & 19.04 & 20.31 \\
\hline Midwest & 31.20 & 49.21 \\
\hline
\end{tabular}

The figures in the table were calculated based on a 1997 Metaevaluation report(2) by Oak Ridge National Laboratory (ORNL), a 2001 ORNL draft report entitled Meeting The Challenge(4) and special tabulations from the 1997 Residential Energy Consumption Survey.(5) Previous years' estimates were based on program resource allocations at levels reflecting a formula bias towards homes in colder dimates in the northeast and midwest. The higher appropriations levels projected for FY 2002 and beyond will be allocated under a formula that shifts a higher proportion of new revenues to the south and west, where savings rates are lower.

Of the units weatherized in FY 2002, 20\% were assumed to have the higher savings rates associated with Weatherization Plus. These savings rates were calculated regionally in the ORNL 2001 draft report $^{(4)}$ and multiplied times the expected number of Plus households in each region.
To develop energy savings by fuel type, the fuel split was based on historical Weatherization program data in the 1997 ORNL report, ${ }^{(2)}$ regarding the primary heating fuel of weatherized households. Because the GPRA metrics are reported only for electricity, natural gas, and fuel oil, the other fuel percentages were allocated within those types based on similarities of emissions. The split was allocated as shown in the table below.

\begin{tabular}{|l|c|l|}
\hline \multicolumn{1}{|c|}{$\begin{array}{c}\text { Primary Heating } \\
\text { Fuel }\end{array}$} & $\begin{array}{c}\text { \% of } \\
\text { Weatherized } \\
\text { Households }\end{array}$ & $\begin{array}{c}\text { Categorized } \\
\text { As }\end{array}$ \\
\hline Natural Gas & 50.6 & Natural Gas \\
Liquid Propane Gas & 13.2 & \\
\hline Fuel Oil & 16.0 & Fuel Oil \\
Kerosene & 3.2 & \\
Other (includes & 7.5 & \\
wood and coal) & & \\
\hline Electricity & 9.5 & Electricity \\
\hline
\end{tabular}

\section{Cost to Weatherize Each Household:}

For FY 2002, \$1,725 was used as an average cost to weatherize each household, not including training and technical assistance and administrative costs. ${ }^{(1)}$ Incremental investment for Weatherization Plus homes, estimated at an average of $\$ 1,400$, was assumed to be derived from leveraged funds. Estimated costs by region for Plus homes are shown in the following table.

\begin{tabular}{|l|l|}
\hline \multicolumn{1}{|c|}{ Region } & $\begin{array}{c}\text { Cost per Plus } \\
\text { Household }\end{array}$ \\
\hline South & $\$ 2,861$ \\
\hline Northeast & $\$ 3,674$ \\
\hline West & $\$ 1,814$ \\
\hline Midwest & $\$ 3,429$ \\
\hline
\end{tabular}

\section{Budget Request and Leveraged Funding:} For FY 2002, leveraged funding of $\$ 235$ million per year was assumed. A 20\% program overhead was subtracted from the total before calculating the number of households weatherized with these funds. Leveraged funding for the DOE Plus homes was 


\section{Weatherization Assistance Program}

Weatherization Assistance Program Decision Unit

estimated to total $\$ 34.7$ million in FY 2002, based on the costs reflected in ORNL's Meeting The Challenge. (4) The balance of leveraged funds were assumed to be used on regular and Plus homes in a 70/30 ratio in FY 2002.

\section{Non-Energy Benefits:}

A net present value of $\$ 161$ per household ${ }^{(3)}$ (1989 \$), adjusted for inflation, was proposed for the FY 2002 effort, based on the estimated non-energy benefits resulting from enhanced property values and extended lifetimes of the dwellings, reduced fires, and reduced arrearages.

\section{Program Strategy (\% of budget):}

- Research and Development - $0 \%$

- Market Transformation - $100 \%$

- Codes and Standards - 0\%.

\section{Sources:}

(1) FY 2002 Budget Request - Data Bucket Report of Weatherization Assistance Program (internal BTS document).

(2) Berry, L.G., M.A. Brown, and L.F. Kinney. 1997. Progress Report of the National Weatherization Assistance Program, ORNL/ CON-450, Oak Ridge National Laboratory.

(3) Brown, M.A., L.G. Bery, R.A. Balzer, and E. Faby, 1993, National I mpacts of the Weatherization Assistance Program in Single-Family and Small Multifamily Dwellings, ORNL/CON-326, Oak Ridge National Laboratory.

(4) Schweitzer, M., Eisenberg J .F. November 2000, Meeting the Challenge: The Prospect of Achieving 30 Percent Energy Savings Through The Weatherization Assistance Program, Draft Analysis. Oak Ridge National Laboratory, ORNL/CON 479.

(5) Eisenberg, J .F., Oak Ridge National Laboratory. Special tabulations for the Weatherization Population derived from the 1997 Residential Energy Consumption Survey. 


\section{Community Energy}




\section{Rebuild America/Energy Smart Schools}

\section{Program Objective:(1)}

The Rebuild America program builds collaborative partnerships with states and communities to help them develop and implement environmentally and economically sound activities through smarter energy use. The program connects people, resources, proven ideas, and innovative practices to solve problems. The program provides onestop shopping for information and assistance on how to plan, finance, implement, and manage retrofit projects to improve buildings' energy efficiency and helps communities find other resources on renewable energy applications, efficient new building designs, energy education, and other innovative energy conservation measures. Rebuild America supports the public/private Energy Smart Schools initiative and competitive Community Energy Grants to encourage community-wide energy projects.

\section{Long-Term Goal:(1)}

The program's long-term goals by 2010 include the following: 2000 partnerships, 4 billion sq ft committed to retrofit ( $\sim 5 \%$ of the market, 2 million sq ft/partnership), $\$ 6$ billion in private investments committed, 0.2 quad of energy saved, and $\$ 1.3$ billion/year savings.

\section{Market Segment:}

\section{Performance Objective:}

- Displaced Technology: Current design/building practices.

- Performance Target: Reduce whole-building energy use of retrofitted and new buildings by $40 \% / \mathrm{sq}$ $\mathrm{ft}$ by 2010 (this is characterized by a 71\% load reduction in space heating, space cooling, and water heating by 2010, which is equivalent to whole-building energy reduction of $40 \%)$. $^{(2)}$

\section{Target Market}

- Market Description: Existing commercial and institutional buildings. General target market includes new and existing multifamily housing, public and assisted single-family residential units, and commercial buildings, particularly, new and existing assembly, health care, lodging, office, education buildings. ${ }^{(3)}$

- Market Size: See the following table.

- Penetration Goal: 2,000 partnerships retrofitting 2 million sq ft each by 2010 . See table below for resulting penetration rates.

\section{Rebuild America}

Program Type:

Whole Building

Target Market:

Existing multifamily residential units $>\$ 25,000 / y r$ income and the commercial sector in all climate zones

End Uses:

All end uses, all fuel types

Unit of Measurement:

$\%$ load reduction

Modeling Tool:

BESET

Program Manager:

Daniel Sze

Website:

http://www.eren.doe.gov/buildings/rebuild/

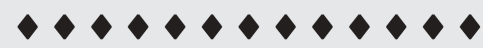

FY 2002 Benefits

Primary Energy Savings (TBtu)

\begin{tabular}{llll}
2002 & 2005 & 2010 & 2020 \\
\hline 1.2 & 15.0 & 41.1 & 47.4
\end{tabular}

Carbon Equivalent Reductions (MMTCE)

\begin{tabular}{cccc}
2002 & 2005 & 2010 & 2020 \\
\hline .021 & .250 & .651 & .770
\end{tabular}

Consumer Cost Savings (million \$)

\begin{tabular}{llll}
2002 & 2005 & 2010 & 2020 \\
\hline 8 & 99 & 296 & 350
\end{tabular}




\section{Rebuild America/Energy Smart Schools}

Community Energy Program Decision Unit

\begin{tabular}{|l|c|c|}
\hline $\begin{array}{l}\text { Market Segments } \\
\text { and Sectors }\end{array}$ & $\begin{array}{c}\text { Floor Space } \\
\text { (billion sq ft) }\end{array}$ & $\begin{array}{c}\text { Energy Use/ } \\
\text { Yr (TBtu) }\end{array}$ \\
\hline Commercial Total & 67.9 & 5,800 \\
\hline $\begin{array}{l}\text { Commercial Local } \\
\text { and State }\end{array}$ & 16.5 & 1,480 \\
\hline $\begin{array}{l}\text { Commercial } \\
\text { Private }\end{array}$ & 51.4 & 4,320 \\
\hline Residential Total & 26.8 & 1,957 \\
\hline $\begin{array}{l}\text { Residential } \\
\text { Public/Assisted } \\
\text { Housing }\end{array}$ & 4.8 & 450 \\
\hline $\begin{array}{l}\text { Residential Private } \\
\text { Multifamily } \\
\text { Housing }\end{array}$ & 22.0 & 1,507 \\
\hline $\begin{array}{l}\text { Total Commercial } \\
\text { and Residential }\end{array}$ & 94.7 & 7,757 \\
\hline
\end{tabular}

\begin{tabular}{|l|l|l|c|c|c|}
\hline \multirow{2}{*}{$\begin{array}{l}\text { Building } \\
\text { Type }\end{array}$} & Vintage & \multicolumn{4}{|c|}{ Penetration Rate } \\
\cline { 3 - 6 } & & Region & $\begin{array}{c}\mathbf{2 0 1 0} \\
(\%)\end{array}$ & $\begin{array}{c}\mathbf{2 0 2 0} \\
(\%)\end{array}$ & $\begin{array}{c}\mathbf{2 0 3 0} \\
(\%)\end{array}$ \\
\hline Assembly & $\begin{array}{l}\text { New \& } \\
\text { Existing }\end{array}$ & $\begin{array}{l}\text { North \& } \\
\text { South }\end{array}$ & 3.5 & 4.0 & 4.0 \\
\hline Education & $\begin{array}{l}\text { New \& } \\
\text { Existing }\end{array}$ & $\begin{array}{l}\text { North \& } \\
\text { South }\end{array}$ & 3.5 & 4.0 & 4.0 \\
\hline $\begin{array}{l}\text { Health } \\
\text { Care }\end{array}$ & $\begin{array}{l}\text { New \& } \\
\text { Existing }\end{array}$ & $\begin{array}{l}\text { North \& } \\
\text { South }\end{array}$ & 3.5 & 4.0 & 4.0 \\
\hline Lodging & $\begin{array}{l}\text { New \& } \\
\text { Existing }\end{array}$ & $\begin{array}{l}\text { North \& } \\
\text { South }\end{array}$ & 3.5 & 4.0 & 4.0 \\
\hline $\begin{array}{l}\text { Office, } \\
\text { Large }\end{array}$ & $\begin{array}{l}\text { New \& } \\
\text { Existing }\end{array}$ & $\begin{array}{l}\text { North \& } \\
\text { South }\end{array}$ & 3.5 & 4.0 & 4.0 \\
\hline $\begin{array}{l}\text { Office, } \\
\text { Small }\end{array}$ & $\begin{array}{l}\text { New \& } \\
\text { Existing }\end{array}$ & $\begin{array}{l}\text { North \& } \\
\text { South }\end{array}$ & 3.5 & 4.0 & 4.0 \\
\hline Multifamily & $\begin{array}{l}\text { New \& } \\
\text { Existing }\end{array}$ & $\begin{array}{l}\text { North \& } \\
\text { South }\end{array}$ & 3.5 & 4.0 & 4.0 \\
\hline $\begin{array}{l}\text { Single } \\
\text { Family }\end{array}$ & $\begin{array}{l}\text { New \& } \\
\text { Existing }\end{array}$ & $\begin{array}{l}\text { North \& } \\
\text { South }\end{array}$ & .12 & .13 & .13 \\
\hline $\begin{array}{l}\text { North = zones with >4,000 heating-degree days; south }= \\
\text { zones with <4,000 heating-degree days. }\end{array}$ \\
\hline
\end{tabular}

\section{Methodology}

Of the 300 million sq $\mathrm{ft}$ added to the program each year, it is assumed that not all of the square footage per partner would be retrofit in one year, but that retrofits (and actual savings) would occur evenly over four years. Penetration rates were calculated using the square footage affected by the program as a percentage of the total square footage in the existing building stock. The load reductions specified in the performance objective were applied to the baseline end-use loads to determine energy savings at the building level. These energy savings were translated into national energy savings using the penetration rates and building stock within the target market and then adjusted using the most recent budget request.

\section{Non-Energy Benefits:(1)}

Revitalized neighborhoods and business districts, improved school facilities, better low-income housing, and positive economic impact from keeping dollars locally and increasing property values.

\section{Program/Technology Consumer Costs:}

- Cost of Conventional Technology: Average of $\$ 81 / \mathrm{sq} \mathrm{ft}$ for new commercial and multifamily; $\$ 0$ for existing buildings.

- Cost of BTS Technology: $\$ 82.60 / \mathrm{sq} \mathrm{ft}$ for new commercial and multifamily; $\$ 3 / \mathrm{sq}$ $\mathrm{ft}$ (2001 to 2009), increasing to $\$ 4 / \mathrm{sq} \mathrm{ft}$ (2010 to 2030) for existing buildings.

- Incremental Cost: 2\% above base for new buildings; $\$ 3 / \mathrm{sq} \mathrm{ft}$ (2001 to 2009) increasing to $\$ 4 / \mathrm{sq} \mathrm{ft}$ (2010 to 2030) for existing buildings.

\section{Program Strategy (\% of budget):}

- Research and Development - 0\%

- Market Transformation - 100\%

- Codes and Standards - 0\%.

\section{Sources:}

(1) FY 2002 Budget Data - Bucket Report for Rebuild America Program.

(2) Table 1.3.6, BTS Core Databook (1999) (internal document) was used to develop equivalent reductions in space heating and cooling and water heating loads.

(3) From a phone conversation with Mark Bailey, former Rebuild America program manager, May 30, 2000. Note the change from previous years where only lodging, health care, office, and education buildings were targeted. 


\section{Information Outreach}

Community Energy Program Decision Unit

\section{Program Objective:(1)}

The Information Outreach program provides BTS with the technical assistance needed to conduct the various planned activities that will educate target audiences. Specifically, the program conceptualizes, plans, and implements a systematic approach to the marketing and communication objectives and evaluation of the programs it supports.

\section{Long-Term Goal:(1)}

By 2010, the program's goal is to support long-term success in developing energy-efficient systems and processes and to improve technology transfer/information exchange.

\section{Market Segment:}

\section{Methodology(2)}

A slightly modified version of an evaluation conducted for the Information Outreach program was used to estimate this program's GPRA benefits. This section draws extensively from the report ${ }^{(2)}$ of that evaluation, which was conducted for protocols used by major public relations firms and prominent measurement organizations. The major aspects of the evaluation protocols are as follows:

- Preparation (BTS activities)

- Adequacy of background information base for designing the program

- Appropriateness of the message and activity

- Quality of the message and activity presentations.

- Implementation (distribution effectiveness)

- Number of messages sent to media and activities designed

- Number of activities placed and activities implemented

- Number who receive messages and activities

- Number who attend to messages and activities.

- Impact (action taken)

- Number who learn message content

- Number who change opinions

- Number who change attitudes

- Number who behave as desired

- Number who repeat behavior

- Social and cultural change.

Information and data from BTS programs, EIA, and the BTS Core Data Book ${ }^{(3)}$ were used within the protocol to estimate energy savings resulting from communications

\section{Information Outreach}

Program Type:

Information/Education

Target Market:

New residential and existing commercial in all climate zones

End Uses:

All end uses, all fuel types

Unit of Measurement:

Energy savings per budget dollar

Modeling Tool:

Spreadsheet

Program Manager:

Lani McRae

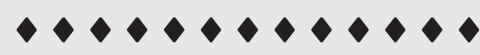

FY 2002 Benefits

Primary Energy Savings (TBtu)

\begin{tabular}{llll}
2002 & 2005 & 2010 & 2020 \\
\hline 44.9 & 126.0 & 105.8 & 99.6
\end{tabular}

Carbon Equivalent Reductions (MMTCE)

\begin{tabular}{llll}
2002 & 2005 & 2010 & 2020 \\
\hline .837 & 2.270 & 1.777 & 1.756
\end{tabular}

Consumer Cost Savings (million \$)

\begin{tabular}{llll}
2002 & 2005 & 2010 & 2020 \\
\hline 277 & 802 & 780 & 762
\end{tabular}




\section{Information Outreach}

Community Energy Program Decision Unit

activities. This evaluation was limited to the major communication deployment efforts supported by BTS. The deployments examined include tradeshows and conferences, BTS web sites, direct mail (induding newsletters), Energy Efficiency and Renewable Energy Clearinghouse (EREC) distribution, hotline, media, and training handouts/tools.

The methodology is summarized as follows:

1. Choose measurable target audiences from BTS strategic plan (e.g., homeowners, commercial builders, and building retrofit decisionmakers) who can implement a BTS strategy, tip, or technology.

2. Determine the energy-savings' potential of each representative in target group from the BTS Core Data Book, ${ }^{(3)}$ BTS programmatic experience, and EIA.

3. Count the total number of impressions from each distribution method and determine how many resulted from commercial builders, building retrofit decisionmakers, and individual homeowners (target group) (see the table).

4. Use industry accepted norms to determine what percentage of the target audience who received message are likely to change their opinion or behavior.

5. Multiply the results in step 4 for each distribution mechanism by the Btu savings' potential calculated for each target audience member in step 2.

The evaluation prepared for the program estimated a total primary energy savings over a $2^{1 / 2}$ year period of 34.8 Tbtu, resulting in an- nual energy savings of 13.92 TBtu. The evaluation further assumed that savings lasted for 3 years, after which they are supplanted by activities the decisionmaker would have undertaken in any event. As a result, savings increase over three years to 41.76 TBtu (13.92 x 3) and then stay constant. In the evaluation,(2) the savings were assumed to be $5 \%$ residential and $95 \%$ commercial, based on the types of decisionmakers the program reaches. The fuel distribution of the savings was assumed to match that of the rest of the BTS portfolio.

\section{Non-Energy Benefits:(1)}

New ideas and technologies, the diversity of stakeholders, and changing stakeholder needs, assumptions, and perceptions all increase the challenges of organizing information and communicating effectively. The American public understands and takes into account the energy benefits of energy usage during purchases, giving the consumer more discretionary dollars.

Program Strategy (\% of budget): ${ }^{(1)}$

- Research and Development - 0\%

- Market Transformation - 100\%

- Codes and Standards - 0\%.

\section{Sources:}

(1) FY 2002 Budget Request - Data Bucket Report for Information Outreach Program (internal BTS document).

(2) Messersmith, J ., and S.A. Azim. August 2000. Communication Effectiveness Analysis for GPRA. Technologists, Inc. (3) BTS Core Data Book, 1999, internal document.

\begin{tabular}{|l|r|r|r|r|}
\hline \multicolumn{5}{|c|}{ Number of Instances a BTS Key Message was Seen or Heard } \\
\hline \multicolumn{1}{|c|}{ Deployment } & FY 2000 & FY 1999 & FY 1998 & Cumulative Impact \\
\hline Conferences (attendees) & 46,300 & 66,650 & 1,000 & 113,950 \\
\hline Internet (page views) & $1,065,477$ & $2,455,135$ & 756,426 & $4,277,038$ \\
\hline Media (circulation & $762,750,432$ & $941,645,457$ & $1,602,561,617$ & $3,306,957,506$ \\
\hline Direct Mail (recipients) & 35,812 & 120,064 & 30,300 & 186,176 \\
\hline EREC (recipients & 17,783 & 58,984 & 68,294 & 145,061 \\
\hline Training (hand-outs) & 0 & 3,500 & 872 & 4,372 \\
\hline Hotline (calls) & 0 & 800 & 1,623 & 2,423 \\
\hline Totals & $763,915,804$ & $944,350,590$ & $1,603,420,132$ & $3,311,686,526$ \\
\hline
\end{tabular}




\section{Program Objective:}

While the Training and Assistance for Codes program receives separate funding allocation, the program is characterized as part of the Residential Building Codes and Commercial Building Codes programs. The benefits for this program are broken out separately from those programs.

For information on this program, see the documentation for Commercial Building Codes and Residential Building Codes programs.

\section{Training and Assistance for Codes}

Program Type:

Information/Education

Target Market:

New residential and commercial buildings in all climate zones

\section{End Uses:}

All end uses, all fuel types

Unit of Measurement:

Savings as the percentage of compliance improvement

\section{Modeling Tool:}

Spreadsheet

\section{Program Manager:}

Jean Boulin

Website:

http://www.eren.doe.gov/ buildings/codes_standards/ bldgstds.htm

FY 2002 Benefits

Primary Energy Savings (TBtu)

\begin{tabular}{llll}
2002 & 2005 & 2010 & 2020 \\
\hline 3.6 & 22.7 & 71.9 & 194.6
\end{tabular}

\section{Carbon Equivalent Reductions} (MMTCE)

\begin{tabular}{cccc}
2002 & 2005 & 2010 & 2020 \\
\hline .069 & .417 & 1.225 & 3.500
\end{tabular}

\section{Consumer Cost Savings (million \$)

\begin{tabular}{llll}
2002 & 2005 & 2010 & 2020 \\
\hline 23 & 147 & 552 & 1,560
\end{tabular}




\section{Energy Star}




\section{Energy Star}

\section{Program Objective(1):}

The Energy Star program increases the market penetration of high-efficiency appliances, windows, and lighting products through consumer education and voluntary industry partnerships. This program works closely with the private sector to bring new technology into the market through approaches such as high-volume purchases, utility program coordination, product testing, labeling, sales training, and provision of technical information to key segments of the market.

\section{Long-Term Goal:(1)}

The program's long-term goal is to achieve a sustained market share of high-efficiency appliances of $20 \%$ by 2010 .

\section{Market Segment:}

\section{Performance Objective:}

- Displaced Technology: Conventional equipment, appliances, and lights.

- Performance Target: Varies by equipment type and size. The following represents a sample of typical Energy Star products on the market:

- Clothes washers - depends on size and type

- Refrigerators - typical refrigerators using -400 kWh/year

- $\quad$ Electric water heaters - energy factor exceeds .9

- Gas water heaters - energy factor exceeds .6

- Room air conditioners - range from 5000 to 1400 Btu/hr, depending on size of unit

- Compact fluorescent lights - typical product would have efficacy of 60 lumens/watt

- Dishwashers - typical product would use 400 to $450 \mathrm{kWh} /$ year.

\section{Target Market}

- Market Description: Determined by program equipment; for FY 2002, the following equipment is characterized:

- clothes washers (residential)

- refrigerators (residential)

- electric water heaters (residential and commercial)

- gas water heaters (residential and commercial)

- room air conditioners (residential)

\section{Energy Star}

\section{Program Type:}

Market Transformation

\section{Target Market:}

Commercial sector and residential housing with $>\$ 25,000 / y r$ incomes in all climate zones

\section{End Uses:}

Heating, cooling, water heating, lighting, and appliances

\section{Unit of Measurement:}

Load/efficiency per affected unit for appliances, air conditioning, water heating, and lighting

\section{Modeling Tool:}

NEMS for appliances, air conditioning, and water heating. Spreadsheet for compact fluorescent lights.

\section{Program Manager: \\ Bill Noel}

Website:

http://www.energystar.gov

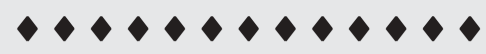

FY 2002 Benefits

Primary Energy Savings (TBtu)

\begin{tabular}{llll}
2002 & 2005 & 2010 & 2020 \\
\hline 42.5 & 120.1 & 199.8 & 206.0
\end{tabular}

Carbon Equivalent Reductions (MMTCE)

\begin{tabular}{llll}
2002 & 2005 & 2010 & 2020 \\
\hline .793 & 2.185 & 3.376 & 3.625
\end{tabular}

Consumer Cost Savings (million \$)

\begin{tabular}{llll}
2002 & 2005 & 2010 & 2020 \\
\hline 292 & 872 & 1732 & 1836
\end{tabular}




\section{Energy Star}

Energy Star Decision Unit

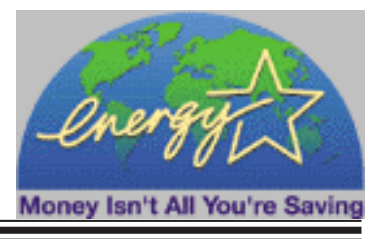

- compact fluorescent lights (residential and commercial)

- dishwashers (residential).

\section{Methodology}

Clothes washers, refrigerators, electric water heaters, gas water heaters, dishwashers, and room air conditioners were modeled in NEMS using input from EIA's Annual Energy Outlook 2000. NEMS inputs were determined such that a $20 \%$ market share is obtained for Energy Star level appliances.

Compact fluorescent lights were modeled in BESET assuming a market penetration of $20 \%$ of the incandescent market in the residential sectors by 2010.
Non-Energy Benefits: (1)

Increased comfort for residential homeowners and office workers and higher profits for manufacturers.

\section{Program Strategy (\% of budget): (1)}

- Research and Development - 1\%

- Market Transformation - 99\%

- Codes and Standards - 0\%.

\section{Sources:}

(1) FY 2002 Budget Request - Data Bucket Report for Energy Star Program (internal BTS document). 


\section{Tech Roadmaps and Competitive R\&D}




\section{Competitive R\&D}

Technology Roadmaps and Competitive R\&D Decision Unit

\section{Program Objective(1):}

The Competitive $R \& D$ program creates a shared vision among diverse groups within each sector and provides a framework for cooperative technology development.

\section{Long-Term Goal:(1)}

The program's long-term goal is to displace 90 TBtu in FY 2010 and 160 TBtu in FY 2020, saving almost $\$ 700$ million and $\$ 1.3$ billion, respectively.

\section{Market Segment:}

\section{Target Market}

- Market Description: Lighting, windows, commercial buildings, and heating, cooling, ventilation, and refrigeration.

- Market Introduction: Technology-dependent.

- Market Penetration Goal: Assumed to be as specified in the 19 proposals funded in FY 1999 as part of the competitive $R \& D$ solicitation. A composite market penetration curve was developed based on the available information in those proposals.

\section{Methodology}

The benefits for this program are based on the adjusted energy savings from the 19 proposals funded in FY 1999. The adjusted average energy savings per dollar of investment were used to estimate the FY 2002 program energy savings. Adjustments were required to account for the projects competing for the same market as another BTS program. This adjustment was made by dividing the market between programs as appropriate. Therefore, the two programs split the market.

If a targeted technology complements a BTS program, the project does not get credit for the entire market. The project either shortens the time to market penetration or increases the final market penetration.

\section{Program/Technology Consumer Costs:}

- Cost of Conventional Technology: Technologydependent.

- Cost of BTS Technology: The incremental cost of the BTS technology will be determined based on the average cost across the proposals.

\section{Competitive R\&D}

Program Type:

ìOtherî -- R\&D Mapping

Target Market:

No specific markets defined

\section{End Uses:}

No specific end uses or fuel types

Unit of Measurement:

Energy savings per budget dollar

Modeling Tool:

Spreadsheet

Program Manager:

John Ryan

FY 2002 Benefits

Primary Energy Savings (TBtu)

\begin{tabular}{llll}
2002 & 2005 & 2010 & 2020 \\
\hline 11.7 & 76.1 & 322.0 & 735.9
\end{tabular}

Carbon Equivalent Reductions (MMTCE)

\begin{tabular}{llll}
2002 & 2005 & 2010 & 2020 \\
\hline 0.219 & 1.380 & 5.428 & 13.078
\end{tabular}

Consumer Cost Savings (million \$)

\begin{tabular}{llll}
2002 & 2005 & 2010 & 2020 \\
\hline 76 & 511 & 2545 & 6074
\end{tabular}




\section{Competitive R\&D}

Technology Roadmaps and Competitive R\&D Decision Unit

\begin{tabular}{ll}
\hline Program/Technology Non-Energy & $\begin{array}{l}\text { Program Strategy (\% of budget):(1) } \\
\text { Costs: }\end{array}$ \\
$\begin{array}{ll}\text { - Cost of Conventional Technology: } & \text { - Market Transformation - } 0 \%\end{array}$ \\
$\begin{array}{l}\text { Technology-dependent. } \\
\text { - Cost of BTS Technology: Technology- } \\
\text { dependent. }\end{array}$ & $\begin{array}{l}\text { Sources: } \\
\text { - Incremental Cost: Technology-dependent. }\end{array}$ \\
$\begin{array}{l}\text { (1) FY } 2002 \text { Budget Request - Data Bucket Re } \\
\text { port for Technology Roadmaps and New and } \\
\text { Innovative R\&D (internal BTS document). }\end{array}$
\end{tabular}




\section{Residential Buildings}




\section{Program Objective:(1)}

The Residential Building R\&D program consolidates the formerly separate systems engineering programs of Building America, Industrialized Housing, Passive Solar Buildings, and Indoor Air Quality programs and existing building research into a comprehensive program to accelerate the introduction of highly efficient building technologies and practices through R\&D of advanced systems for production builders.

\section{Long-Term Goal:(1)}

The long-term goal of the program is to develop advanced systems to improve the energy performance of over 300,000 of the 1 million homes that will be built in 2010. The performance increase will allow the homes to use $50 \%$ less energy for space conditioning and water heating than typical homes built in 1993.

\section{Market Segment:}

Performance Objective:(2)

- Displaced Technology: Current design/building practices.

- Performance target: $50 \%$ load reduction in space heating and cooling and water heating by 2010 .

\section{Target Market ${ }^{(1)}$}

- Market Description: New single-family, multifamily, and manufactured housing units with over $\$ 25,000$ annual income in all dimate zones. Primarily new singlefamily homes, multifamily infill, HUD code homes, and small commercial buildings. Existing homes are to benefit from new technologies and improved construction practices developed for new homes.

- Size of Market: 1.4 million new housing units built each year. About 31.1 million existing households have annual incomes from $\$ 25,000$ to $\$ 50,000$. (The Weatherization program targets the lower-income households). These homes account for 52,165 million sq $\mathrm{ft}$ of floor space and use 3.19 quadrillion Btu and are primarily owner occupied.

- Market Introduction: 1997.(2)

- Market Penetration Goal: ${ }^{(3)}$ See table below.
Residential Buildings R\&D

Program Type:

Whole Building

Target Market:

New single-family, multifamily, and manufactured housing units with $>\$ 25,000 / y r$ income in all climate zones

End Uses:

All end uses, all fuel types

Unit of Measurement:

$\%$ load reduction

Modeling Tool:

BESET

Program Manager:

George James/Jon Stone

Website:

http://www.eren.doe.gov/

building/building_america/

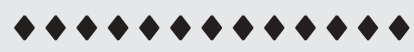

FY 2002 Benefits

Primary Energy Savings (TBtu)

\begin{tabular}{llll}
2002 & 2005 & 2010 & 2020 \\
\hline 0.1 & 1.1 & 8.6 & 19.9
\end{tabular}

Carbon Equivalent Reductions (MMTCE)

\begin{tabular}{llll}
2002 & 2005 & 2010 & 2020 \\
\hline .003 & .018 & .134 & .322
\end{tabular}

Consumer Cost Savings (million \$)

\begin{tabular}{llll}
2002 & 2005 & 2010 & 2020 \\
\hline 1 & 8 & 65 & 153
\end{tabular}


Residential Buildings Integration Decision Unit

\begin{tabular}{|c|c|c|}
\hline \multicolumn{3}{|c|}{$\begin{array}{c}\text { Market Penetration Curve: } \\
\text { FY 2002 Estimate } \\
\text { (actual numbers, previous years) }\end{array}$} \\
\hline Year & \# Builders & \# Homes \\
\hline 2001 & 38 & 3,600 \\
\hline 2002 & 48 & 7,200 \\
\hline 2003 & 60 & 14,400 \\
\hline 2004 & 76 & 25,200 \\
\hline 2005 & 96 & 44,100 \\
\hline 2006 & 121 & 77,175 \\
\hline 2007 & 152 & 111,904 \\
\hline 2008 & 192 & 156,665 \\
\hline 2009 & 242 & 203,665 \\
\hline 2010 & 305 & 254,581 \\
\hline 2011 & 384 & 305,497 \\
\hline 2012 & 484 & 351,322 \\
\hline 2013 & 610 & 386,454 \\
\hline 2014 & 769 & 417,370 \\
\hline 2015 & 969 & 446,586 \\
\hline 2016 & 1,220 & 473,381 \\
\hline 2017 & 1,538 & 497,050 \\
\hline 2018 & 1,938 & 516,933 \\
\hline 2019 & 2,441 & 532,440 \\
\hline 2020 & 3,076 & 543,089 \\
\hline & & \\
\hline
\end{tabular}

\section{Methodology}

For any one year, energy savings are calculated by multiplying the number of homes built with Building America techniques that year times the percent savings per home. Added to this are the energy savings, in that year, for Building America homes built in previous years (within the analysis period, any savings resulting from homes built prior to 2002 are not included).

\section{Non-Energy Benefits:(1)}

Consumer savings of $\$ 148$ million by 2010 ; improved comfort, durability, and occupant health from better indoor air quality; and reduced onsite generated waste, better sustainability, and reduced maintenance.

\section{Program/Technology Consumer Costs:}

- Cost of Conventional Technology (average price per household [\$/household):

- Single family: \$126,700/household

- Multifamily: \$74,900/household

- Manufactured home: \$41,100/household.

\section{Program Strategy (\% of budget):(1)}

- Research and Development - 90\%

- Market Transformation - $10 \%$

- Codes and Standards - 0\%.

\section{Sources:}

(1) FY 2002 Budget - Data Bucket Template Residential Building Integration R\&D (internal BTS document).

(2) FY 2001 GPRA Program Characterization (internal document).

(3) Based on I mpacts spreadsheet developed by Ren Anderson, August 10, 2000. 


\section{Program Objective:(1)}

The Residential Building Codes program improves the energy efficiency of new residential buildings and additions and alterations to existing buildings. The objective will be accomplished by improving the energy-efficiency provisions of building codes and applicable standards that affect residential construction and by providing technical assistance for implementing those codes and standards.

\section{Long-Term Goal:(1)}

The program's long-term goal for applicable residential building codes is to incorporate the most technologically feasible, economically justified energy conservation measures. Another goal is to provide state and local governments with the needed technical tools and information for adopting, using, and enforcing efficient building codes for residential construction. These goals can be quantified in terms of the percentage improvements in efficiency in existing residential building codes, the number of jurisdictions that adopt and successfully implement these codes, the number of new houses built in compliance with the new code, and the number of renovations and additions to existing buildings complying with code.

\section{Market Segment:}

\section{Target Market ${ }^{(1)}$}

- Market Description: New residential buildings that are generally three stories or less in height (taller buildings fall under the commercial buildings program) and additions and alterations to existing buildings. The program can affect residences' major energy end uses: heating, cooling, and water heating and possibly lighting energy in the near future. All areas of the country are affected because the model building codes and standards cover all dimate zones. Household income is not a discrimination of the target market because building codes cover housing at all costs and income levels. Energy-efficiency improvements via codes have repeatedly demonstrated a net positive cash flow to the new home buyer within five years, thus actually improving household income.

- Size of Market: About 1.4 million building permits were issued last year, over a million for single-family dwellings. Although not all jurisdictions currently have energy-efficiency building codes in place, about

\section{Residential Building} Codes

Program Type:

Information/Education

Target Market:

New residential buildings in all climate zones

End Uses:

All end uses, all fuel types

Unit of Measurement:

$\%$ load reduction

Modeling Tool:

Spreadsheet

Program Manager:

Steve Walder

Website:

http://www.eren.doe.gov/buildings/ codes_standards/bldgstds.htm

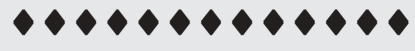

FY 2002 Benefits

Primary Energy Savings (TBtu)

\begin{tabular}{llll}
2002 & 2005 & 2010 & 2020 \\
\hline 0.1 & 1.2 & 8.7 & 32.5
\end{tabular}

Carbon Equivalent Reductions (MMTCE)

\begin{tabular}{cccc}
2002 & 2005 & 2010 & 2020 \\
\hline .002 & .020 & .136 & .521
\end{tabular}

Consumer Cost Savings (million \$)

\begin{tabular}{llll}
2002 & 2005 & 2010 & 2020 \\
\hline 1 & 9 & 65 & 247
\end{tabular}


half of all new residential construction are conservatively estimated to come under building code requirements. Also, consumers spend several billion dollars a year remodeling and renovating private residences, half of which could presently be covered by an energy code. One market not currently covered by codes is manufactured homes, which fall under HUD's jurisdiction and are governed by HUD regulations.

\section{Methodology}

The program's impact is primarily through two avenues: 1) developing and supporting code changes to improve energy efficiency in residential structures, and 2) developing tools that can ease the adoption of new codes, and through their use, support improvements in compliance and enforcement of new code provisions.

\section{Estimated Savings Per Household:}

DOE has not established estimated code impacts, which may change given review of proposed activities. Because specific code changes are not identified, code improvements are uncertain. The FY 2001 extended outlook was based on a modest $1 \%$ reduction in cooling and heating loads in 2010, 2015, and 2025 from a 1995 Model Energy Code (now IECC) baseline. While no specific code changes to achieve this are identified, this level of change appears achievable based on past program experience.

Energy savings from improvements in adopting and complying with new codes are based on modeling energy improvements in the IECC over existing 1995 MEC efficiency levels. States are assumed to have complied with the 1995 MEC. The following is also assumed to occur by 2010:

- States that have adopted some form of the MEC eventually will adopt some form of the IECC requirements (29 states, $\sim 31.7 \%$ of new construction).

- Spedific states that are non-MEC compliant will potentially adopt a national code like the IECC (14 states, $-26.3 \%$ of new construction).
- Specific states that currently don't have mandatory residential energy codes will likely adopt an energy code in the near future (6 states, $-8.4 \%$ of new construction).

Compliance rates are based on average compliance rates for residential codes, in general estimated at $43 \%$ in 2000 and dimbing to $65 \%$ in 2010 and $75 \%$ in 2020. Compliance is increased through better familiarity with the code over time, simplifications to the code while maintaining stringency, and the availability and increased use of compliance tools by builders and enforcement officials.

BTS has not provided any specific estimates for potential energy savings from residential codes. The above methodology is consistent with the methodology used in the GPRA FY 2001 estimates. Energy-efficiency improvements through updates to energy codes are PNNL conjecture and should be run through the Residential BRS Team. Note, no task for residential technical assistance was defined separately from the residential codes task. Currently, all savings estimated for new codes are captured by this Residential Buildings Codes program estimate.

\section{Non-Energy Benefits:(1)}

Lower utility bills, improved indoor comfort, lower home maintenance and repair activities, and reduced pollution from burning fossil fuels and generating electricity, which improves air quality and mitigates the negative impacts of global warming.

\section{Program Strategy (\% of budget): $:^{(1)}$}

- Research and Development - 0\%

- Market Transformation - 0\%

- Codes and Standards - 100\%.

\section{Sources:}

(1) FY 2002 Budget - Data Bucket Report for Residential Building Integration $R \& D$ Program (internal BTS document). 


\section{Commercial Buildings}




\section{Program Objective:}

The Commercial Buildings R\&D program develops and demonstrates advanced technologies, controls, and equipment in collaboration with the design and construction community. The program focuses on advancing integrated technologies and practices to optimize whole-building energy performance. The program reduces energy use in commercial and multifamily buildings by promoting practices that help ensure the industry constructs buildings as designed and operates them at or near the optimum level of performance.

\section{Long-Term Goal:}

The program's long-term goal is to improve by $30 \%$ the energy efficiency of the nation's new commercial buildings and existing buildings by 20\% by 2010 compared with 1996 .

\section{Market Segment:}

\section{Performance Objective:}

- Displaced Technology: Conventional design/ building practices.

- Performance Target: Reduce heating and cooling loads by $30 \%$ in new construction and by $20 \%$ in existing units compared with 1996.

\section{Target Market ${ }^{(1)}$}

- Market Description: Commercial buildings that the program's research products are most likely to impact; includes all commercial buildings except those using very low amounts of energy ( $<10 \%$ of average building consumption) and those having very low energy-use intensities ( $<50 \%$ of the average energy-use intensity).

- Market Introduction: 1996 (inception date of program is 1977).

- Market Penetration Goal: To penetrate $5 \%$ of all multifamily existing residential buildings and $5 \%$ of targeted existing commercial buildings by 2020 . In addition, penetrate $5 \%$ of new residential and targeted commercial buildings in combination with the Analysis Tools and Design Strategies program.

\section{Non-Energy Benefits:}

Reduced operation and maintenance expenses, improved indoor environmental quality, increased prop-

\section{Commercial Buildings $R \& D$}

Program Type:

Whole Building

Target Market:

New and existing commercial and residential multifamily units in all climate zones

End Uses:

Heating and cooling

Unit of Measurement:

$\%$ load reduction

Modeling Tool:

BESET

Program Manager:

Dru Crawley

Website:

http://www.eren.doe.gov/buildings/ high performance

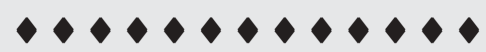

FY 2002 Benefits

Primary Energy Savings (TBtu)

\begin{tabular}{llll}
2002 & 2005 & 2010 & 2020 \\
\hline 0.0 & 0.0 & 1.8 & 8.8
\end{tabular}

Carbon Equivalent Reductions (MMTCE)

\begin{tabular}{llll}
2002 & 2005 & 2010 & 2020 \\
\hline .000 & .000 & .030 & .148
\end{tabular}

Consumer Cost Savings (million \$)

\begin{tabular}{llll}
2002 & 2005 & 2010 & 2020 \\
\hline 0 & 0 & 13 & 65
\end{tabular}




\section{Commercial Buildings R\&D}

Commercial Buildings Integration Decision Unit

erty asset value, higher tenant satisfaction and retention rates, and increased product sales.

\section{Program Strategy (\% of budget):}

- Research and Development - 90\%; The bulk of funding is research focused on high- performance building techniques, fault detection and diagnostics, indoor environmental quality, building commissioning, and integrated building systems.

- Market Transformation - 10\%; Small initiatives were established with the Building America and Rebuild America programs to incorporate high-performance building research into their deployment activities to create direct linkages between the separate $R \& D$ and deployment programs, which are focused on the same target markets.

- Codes and Standards - 0\%.

\section{Sources:}

(1) FY 2002 Budget - Bucket Report for Commercial Buildings Integration R\&D Program (internal BTS document). 


\section{Program Objective:(1)}

The Commercial Buildings Codes program promotes energy efficiency by promulgating federal energy codes while working with model code groups to upgrade building codes and standards that state and local jurisdictions can adopt and that are applicable to all new commercial and high-rise residential buildings, permitted renovations, and additions. This program targets all new commercial buildings, with federal construction representing about 3\% of all new construction.

\section{Long-Term Goal:(1)}

The program's long-term goal is to reduce total energy use by $30 \%$ to $35 \%$ in all new commercial building construction by the year 2010. Energy use will be reduced by the widespread adoption of building energy codes by all states and U.S. jurisdictions. The program is also establishing an educational library consisting of manuals, software, and training support for both voluntary commercial and federal commercial energy-efficiency codes.

\section{Market Segment:}

\section{Target Market}

- Market Description: All new commercial and multifamily high-rise buildings and all permitted additions and renovations to those buildings.

- Size of Market: About 4.7 million buildings representing 62.9 billion sq ft of floor space, consuming about 7.7 quad of energy onsite and costing $\$ 85.2$ billion annually. The federal sector represents about $2.3 \%$ overall of new commercial building construction.

Energy savings from this program and the related Technical Assistance for Codes result from basic improvements in overall energy efficiency of commercial buildings. The present funding method channels funding for conducting research activities for new codes and for developing compliance tools - primarily for existing codes - through BTS's Building Research and Standards area. Funding for the Training and Technical Assistance for state building energy codes (related primarily to existing codes) is channeled through BTS Building Technology Assistance area. Benefits cannot be clearly allocated to either area.

\section{Commercial Buildings Codes}

Program Type:

Information/Education

Target Market:

New commercial buildings in all climate zones

End Uses:

All end uses, all fuel types

Unit of Measurement:

$\%$ load reduction

Modeling Tool:

Spreadsheet

Program Manager:

Ron Majette

Website:

http://www.eren.doe.gov/buildings/ codes_standards/bldgstds.htm

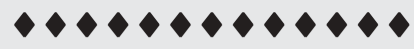

FY 2002 Benefits

Primary Energy Savings (TBtu)

\begin{tabular}{llll}
2002 & 2005 & 2010 & 2020 \\
\hline 0.3 & 3.5 & 7.8 & 31.9
\end{tabular}

Carbon Equivalent Reductions (MMTCE)

\begin{tabular}{cccc}
2002 & 2005 & 2010 & 2020 \\
\hline .006 & .065 & .130 & .562
\end{tabular}

Consumer Cost Savings (million \$)

\begin{tabular}{llll}
2002 & 2005 & 2010 & 2020 \\
\hline 2 & 23 & 56 & 242
\end{tabular}


Barring future guidance from DOE, benefits for FY 2002 were assumed to be allocated according to ratio of actual funding levels. The description of the methodology below also pertains to Technical Assistance for Codes.

The program's impact is primarily through two avenues: 1) developing and supporting standard/code changes to improve energy efficiency in commercial building structures and 2) developing tools that can ease the adoption of new codes, and through their use, support improvements in compliance and enforcement of code provisions. Tools take the form of code compliance software, computer-based training tools for building energy codes, and non-computerbased code implementation tools.

Changes to building standards and codes are primarily supported by research efforts to review existing codes and specific targeted areas of building energy use and the adoption of code modifications that promote costeffective reductions in these energy use areas. The research work has typically taken place on three fronts: support for ASHRAE/IES 90.1, support for developing federal building codes, and support for developing the IECC.

Code improvement energy savings are based on an estimated percentage reduction in wholebuilding energy-use intensity from code changes affecting lighting, cooling, and space heating loads over base code levels. Building simulation estimates of code-to-code energy savings between ASHRAE 90.1-1989,(2) used as a proxy for existing U.S. building codes, and proposed code versions of 90.1-1999, (3) have influenced the acceptance of 90.1 revisions. Near-term increases in energy efficiency are expected to come less from increases in the stringency of the voluntary standard and more from a larger fraction of buildings.

Energy savings from improvements in adoption and compliance with new codes are based on estimates of target improvements in new codes in comparison with an ASHRAE
90.1-1999 baseline level. In the past, estimates for changes to equipment efficiency have not been used to establish the code-tocode energy savings because these savings were to be reflected in the separate EPAct Standards Program. The following is assumed to occur by 2010 :

- States that have adopted some form of ASHRAE Standard 90.1-1989(2) by reference will adopt some form of the 90.1-1999 or IECC 2001 requirements (24 states, $-31.2 \%$ of new commercial construction).

- Specific states that reference noncompliant national codes (chiefly ASHRAE Standard 90a-1980)(3) will adopt a commercial code equivalent to 90.1-1999 to meet requirements of EPAct (11 states, $18.6 \%$ of new construction).

- States that have state-developed codes that presently exceed 90.1-1989 will develop codes that exceed 90.1-2002, 90.12005, and $90.1-2008$ (6 states, $-26.8 \%$ of new construction).

Compliance rates are based on an assumed average compliance rate of $43 \%$ in 2000 , climbing to $80 \%$ in 2010 . Compliance represents percent achievement of the nominal energy savings differential estimated between base 90.1-1989 code ${ }^{(2)}$ and new codes.

\section{Non-Energy Benefits:}

Improved environment and more comfortable buildings.

\section{Sources:}

(1) FY 2002 Budget - Data Bucket Report for Commercial Building Codes Program (internal BTS document).

(2) ASHRAE Standard 90.1-1989, “Energy Efficient Design of New Buildings Except Low-Rise Residential Buildings."

(3) ASHRAE Standard 90a-1980, "Energy Efficient Design of New Buildings Except Low-Rise Residential Buildings." 


\section{Equipment, Materials and Tools}




\section{Lighting R\&D}

Equipment, Materials, and Tools Decision Unit

\section{Program Objective(1):}

The Lighting R\&D program develops and accelerates the introduction of advanced lighting technologies. A new initiative in this program, solid-state lighting, will foster the introduction of solid-state lighting and will seek to achieve the following for lighting:

- Significantly greater efficiency than conventional sources

- Easily integrated into building systems of the future

- Able to provide the appropriate color and intensity for any application

- Lasting for 20,000 to 100,000 hours

- Able to readily supplement natural sunlight.

\section{Long-Term Goal:(1)}

The program's Iong-term goal is to reduce energy use for lighting by $50 \%$ by 2020 .

\section{Market Segment \\ Target Market}

- Market Description: All commercial buildings.

- Size of Market: The commercial building stock was about 63 billion sq ft in 2000, and lighting uses 26\% (3.9 quad) of the primary energy in commercial buildings.

\section{Methodology}

The energy savings from the lighting program was generally based on the BTS Program Manager's judgment on the probable penetration of specific lighting technologies. However, the resulting savings are formally calculated from the NEMS commercial energy module. The capital costs of the technologies are adjusted to achieve approximate congruence with the external penetration assumptions.

For the solid-state lighting initiative, key assumptions concerning the likely dates of introduction and the expected efficacies were influenced by a recent white paper, "The Case for a National Research Program on Semiconductor Lighting."(2) This paper was prepared by staff from Hewlett-Packard and Sandia National Laboratories and was presented in late 1999 at an industry forum.

As was done in FY 2001, the NEMS model was used to project savings from the lighting program. The current

\section{Lighting R\&D}

Program Type:

Equipment Efficiency

\section{Target Market:}

Potentially all sectors and all climate zones (primarily impacts commercial sectors and higherincome residential buildings)

\section{End Uses:}

Lighting and electricity

Unit of Measurement:

Lumens/Watt

\section{Modeling Tool:}

NEMS

\section{Program Manager: \\ Ron Lewis}

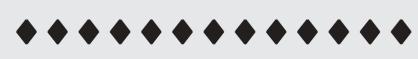

FY 2002 Benefits

Primary Energy Savings (TBtu)

\begin{tabular}{llll}
2002 & 2005 & 2010 & 2020 \\
\hline 0.0 & 2.1 & 63.2 & 330.8
\end{tabular}

Carbon Equivalent Reductions (MMTCE)

\begin{tabular}{cccc}
2002 & 2005 & 2010 & 2020 \\
\hline .000 & .039 & 1.080 & 5.991
\end{tabular}

Consumer Cost Savings (million \$)

\begin{tabular}{llll}
2002 & 2005 & 2010 & 2020 \\
\hline 0 & 14 & 481 & 2,636
\end{tabular}




\section{Lighting R\&D}

Equipment, Materials, and Tools Decision Unit

model allows the BTS technology to compete with a wide variety of technologies. The issue is complicated by EIA's use of functions to represent dedining costs of new technologies. Accordingly, the same general approach was followed as for the FY 2001 effort in which costs of the BTS technologies were adjusted to achieve some congruence with the expected penetration rates. If some reasonable basis for future costs can be developed, these costs can be put into the model to determine economic viability.

For the FY 2002 estimates, the lighting estimates were based on NEMS projections that included two technologies supported by BTS: 1) solid-state lighting and 2) the two-photon phosphor lamp. In NEMS, each lighting technology is characterized by an efficacy level (lumens/watt), a capital cost ( $\$ / 1000$ lumens), and an annual cost of lamps (\$/1000 lumens). F or new technologies, the capital costs can be re duced along a logistic-shaped curve.

For solid-state lighting, Table 1 summarizes the cost inputs for some of the key lighting technologies used in NEMS for FY 2002. NEMS divides the commercial lighting market into four major groups: 1) incandescent (point source), 2) 4-foot fluorescent, 3) 8-foot fluorescent, and 4) high-intensity point source (outdoor lighting). Solid-state lighting was assumed to penetrate the first three market groupings; the two-photon phosphor lamp was assumed to compete only with the fluorescent lighting groups. Table 2 summarizes the cost inputs for the two-photon phosphor program.

Given these costs, NEMS chooses among these technologies for each building type in each census division. For each combination, the market was assumed to consist of various segments, each with a different discount rate. Within each segment, a lighting technology was selected on the basis of minimum annualized cost.

Table 3 summarizes the results of the market shares generated by NEMS for FY 2002. The

\begin{tabular}{|c|c|c|c|c|}
\hline $\begin{array}{l}\text { Lighting } \\
\text { Technology }\end{array}$ & $\begin{array}{c}\text { Efficacy } \\
\text { (Iumen/ } \\
\text { watt) }\end{array}$ & $\begin{array}{c}\text { Capital } \\
\text { Cost, } \\
2010 \\
\text { (\$/1000 } \\
\text { lumen) }\end{array}$ & $\begin{array}{c}\text { Capital } \\
\text { Cost, } \\
2020 \\
\text { (\$/1000 } \\
\text { lumen) }\end{array}$ & $\begin{array}{c}\text { Annual } \\
\text { Operating } \\
\text { Cost } \\
\text { (\$/1000 } \\
\text { lumens) }\end{array}$ \\
\hline \multicolumn{5}{|l|}{ Incandescent } \\
\hline Incandescent & 15.6 & 34.02 & 34.02 & 10.72 \\
\hline $\begin{array}{l}\text { Compact } \\
\text { Fluorescent } \\
\text { Light }\end{array}$ & 66.7 & 37.74 & 36.79 & 6.21 \\
\hline $\begin{array}{l}\text { Solid-State } \\
\text { Lighting, } 2005\end{array}$ & 40 & 40.00 & 40.00 & 0.51 \\
\hline $\begin{array}{l}\text { Solid-State } \\
\text { Lighting, } 2010\end{array}$ & 60 & 30.00 & 30.00 & 0.51 \\
\hline $\begin{array}{l}\text { Solid-State } \\
\text { Lighting, } 2015\end{array}$ & 80 & NA & 25.00 & 25.00 \\
\hline \multicolumn{5}{|c|}{ 4-Foot Fluorescent } \\
\hline $\begin{array}{l}\text { F32T8 } \\
\text { Electronic }\end{array}$ & 84.2 & 23.64 & 23.46 & 0.51 \\
\hline $\begin{array}{l}\text { Solid-state } \\
\text { Lighting, } 2010\end{array}$ & 60 & 25.00 & 25.00 & 0.51 \\
\hline $\begin{array}{l}\text { Solid-state } \\
\text { Lighting, } 2015\end{array}$ & 80 & NA & 20.00 & 0.51 \\
\hline \multicolumn{5}{|c|}{ 8-Ft Fluorescent } \\
\hline $\begin{array}{l}\text { F96T12 } \\
\text { Electronic }\end{array}$ & 73.9 & 7.49 & 7.49 & 7.49 \\
\hline $\begin{array}{l}\text { Solid-state } \\
\text { Lighting, } 2010\end{array}$ & 60 & 10.00 & 10.00 & 0.39 \\
\hline $\begin{array}{l}\text { Solid-state } \\
\text { Lighting, } 2015\end{array}$ & 80 & NA & 7.00 & 0.39 \\
\hline
\end{tabular}

\begin{tabular}{|c|c|c|c|c|}
\hline $\begin{array}{l}\text { Lighting } \\
\text { Technology }\end{array}$ & $\begin{array}{c}\text { Efficacy } \\
\text { (lumens/ } \\
\text { watt) }\end{array}$ & $\begin{array}{c}\text { Capital } \\
\text { Cost, } \\
2010 \\
\text { (\$/1000 } \\
\text { lumen) }\end{array}$ & $\begin{array}{c}\text { Capital } \\
\text { Cost, } \\
2020 \\
\text { (\$/1000 } \\
\text { lumen) } \\
\end{array}$ & $\begin{array}{c}\text { Annual } \\
\text { Operating } \\
\text { Cost } \\
\text { (\$/1000 } \\
\text { lumens) }\end{array}$ \\
\hline \multicolumn{5}{|c|}{ 4-Foot Fluorescent } \\
\hline \begin{tabular}{|l} 
F32T8 \\
Electronic
\end{tabular} & 84.2 & 23.64 & 23.46 & 0.51 \\
\hline $\begin{array}{l}\text { Two-photon } \\
\text { phosphor (2010 } \\
\text { introduction) }\end{array}$ & 160 & 26.00 & 17.60 & 0.51 \\
\hline
\end{tabular}

market shares relate to the sales of new and re placement equipment in the year shown. Given the assumed 12-year life for lighting equipment, the market shares in the existing stock would be much lower than the shares shown in the table.

\section{Non-Energy Benefits:}

Helps maintain U.S. semi-conductor leadership, develops U.S. leadership in lighting 


\section{Lighting R\&D}

Equipment, Materials, and Tools Decision Unit

\begin{tabular}{|c|c|c|c|c|}
\hline \multicolumn{5}{|c|}{ Solid State Lighting } \\
\hline Incandescent & 2005 & 2010 & 2015 & 2020 \\
\hline $\begin{array}{l}\text { Incandescent } 1170 \text { Lumens, } \\
75 \text { watt }\end{array}$ & 0.38 & 0.26 & 0.14 & 0.08 \\
\hline $\begin{array}{l}\text { Compact Fluorescent Light } \\
786 \text { Lumens, } \\
14.6 \text { Watts ----> } 18 \text { watt } \\
1200 \text { lumen }\end{array}$ & 0.44 & 0.28 & 0.17 & 0.11 \\
\hline $\begin{array}{l}\text { Solid-state Lightingñ } 2005 \\
\text { Intro (40 watt/ lumen) }\end{array}$ & 0.07 & 0.32 & 0.44 & 0.33 \\
\hline $\begin{array}{l}\text { Solid-state Lightingñ } 2010 \\
\text { Intro (60 watt/ lumen) }\end{array}$ & & 0.08 & 0.13 & 0.10 \\
\hline \begin{tabular}{|l|} 
Solid-state Lightingñ 2015 \\
Intro (80 watt/ lumen)
\end{tabular} & & & 0.08 & 0.37 \\
\hline \multicolumn{5}{|l|}{ 4-Foot Fluorescent } \\
\hline Standard Magnetic & 0.16 & 0.10 & 0.07 & 0.05 \\
\hline Efficient Magnetic & 0.14 & 0.09 & 0.06 & 0.04 \\
\hline F32T8 ñ Magnetic & 0.16 & 0.10 & 0.06 & 0.04 \\
\hline F32T8 ñ Electronic & 0.24 & 0.40 & 0.45 & 0.30 \\
\hline \begin{tabular}{|l|} 
F32T8 ñ Electronicñ \\
Reflector \\
\end{tabular} & 0.22 & 0.21 & 0.19 & 0.12 \\
\hline $\begin{array}{l}\text { Solid-state (2015 intro- } \\
\text { duction, } 80 \text { watt/lumen) }\end{array}$ & 0 & 0 & 0.09 & 0.40 \\
\hline \multicolumn{5}{|l|}{ 8-Foot Fluorescent } \\
\hline Standard Magnetic & 0.15 & 0.10 & 0.06 & 0.04 \\
\hline \begin{tabular}{|l} 
Efficient MagneticñEnergy \\
Saver
\end{tabular} & 0.10 & 0.06 & 0.04 & 0.03 \\
\hline ElectronicñEnergy Saver & 0.35 & 0.46 & 0.48 & 0.32 \\
\hline ElectronicñHigh Output & 0.20 & 0.24 & 0.27 & 0.27 \\
\hline \begin{tabular}{|l|} 
Solid-state $(2015$ \\
introduction)
\end{tabular} & & & 0.06 & 0.29 \\
\hline \multicolumn{5}{|l|}{ 4-Foot Fluorescent } \\
\hline Standard Magnetic & 0.16 & 0.10 & 0.07 & 0.04 \\
\hline Efficient Magnetic & 0.14 & 0.09 & 0.06 & 0.04 \\
\hline F32T8 - Magnetic & 0.16 & 0.10 & 0.06 & 0.04 \\
\hline F32T8 - Electronic & 0.24 & 0.40 & 0.52 & 0.56 \\
\hline $\begin{array}{l}\text { F32T8 - Electronic ñ } \\
\text { Reflector }\end{array}$ & 0.22 & 0.21 & 0.18 & 0.12 \\
\hline \multicolumn{5}{|l|}{ 8-Foot Fluorescent } \\
\hline Standard Magnetic & 0.15 & 0.10 & 0.06 & 0.04 \\
\hline \begin{tabular}{|l|} 
Efficient MagneticñEnergy \\
Saver
\end{tabular} & 0.10 & 0.06 & 0.04 & 0.03 \\
\hline ElectronicñEnergy Saver & 0.35 & 0.46 & 0.51 & 0.50 \\
\hline ElectronicñHigh Output & 0.20 & 0.24 & 0.26 & 0.26 \\
\hline
\end{tabular}

technology, reduces pollution and contributes to U.S. climate change goals, and improves U.S. productivity from better lighting in work environments.

Program Strategy (\% of budget):

- Research and Development - 80\%

- Market Transformation - $20 \%$

- Codes and Standards - 0\%.

\section{Sources:}

(1) FY 2002 Budget Request - Data Bucket Report for Lighting R\&D Program (internal BTS document).

(2) Haitz, R., and F. Kish. October 6, 1999. "The Case for a National Research Program on Semiconductor Lighting." Sandia National Laboratories. White paper presented at the 1999 Optoel ectronics I ndustry Development Association forum in Washington D.C. 


\section{Space Conditioning and Refrigeration R\&D}

Equipment, Materials, and Tools Decision Unit

\section{Program Objective:(1)}

The Space Conditioning and Refrigeration R\&D program develops and promotes the use of commercial food display and storage technologies that use less energy and less refrigerant. Water-heating activities center on developing low-cost, high-reliability heat pump water heater concepts. The technology supported under this program is intended to reduce the energy losses incurred in transferring heating or cooling from the conditioning unit(s) (e.g., heat pump, furnace, and air conditioner) to the conditioned space.

\section{Long-Term Goal: (1)}

The program's long-term goal is to reduce energy for building HVAC and refrigeration equipment over the next 15 to 20 years. Specific goals include reducing energy use for electric water heating by at least $50 \%$; building space heating and cooling by $20 \%$ to $25 \%$, respectively; and supermarket refrigeration and HVAC energy use by at least $15 \%$, while reducing the level of refrigerant needed.

\section{Market Segment:}

\section{Target Market}

- Market Description:(1) Commercial refrigeration, a broad dassification of building equipment that collectively consumes about one quad of energy annually in the United States. Supermarkets consume about onethird of the energy of commercial refrigeration, with self-contained refrigeration equipment consuming about two-thirds of that energy. Residential applications include air conditioners, heat pumps, heat pump water heaters, and thermal distribution systems.

- Size of Market: (1) Commercial refrigeration markets include about 30,000 large supermarkets and 100,000 convenience stores. Other markets include hospitals, large institutional buildings, and restaurants. Residential markets indude space conditioning and water heating in about 1.2 million annual new and 72.5 million existing single-family homes.

\section{Methodology}

For FY 2002, three technologies were modeled: residential HVAC distribution systems, advanced electric heat pump water heaters, and commercial refrigeration.

\section{Space Conditioning and Refrigeration R\&d}

Program Type:

Equipment Efficiency

\section{Target Market:}

Refrigeration: Commercial food sales in all climate zones.

Heat pump water heater and HVAC distribution: Residential.

\section{End Uses:}

Heating and cooling and water heating

\section{Unit of Measurement:}

Refrigeration: kWh/year

Heat Pump Water Heater: efficiency/unit

HVAC Dist: \% load reduction

\section{Modeling Tool:}

Refrigeration and heat pump water heater: Spreadsheet HVAC Dist: BESET

Program Manager:

Esher Kweller

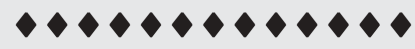

FY 2002 Benefits

Primary Energy Savings (TBtu)

\begin{tabular}{llll}
2002 & 2005 & 2010 & 2020 \\
\hline 5.6 & 18.5 & 46.3 & 93.3
\end{tabular}

Carbon Equivalent Reductions (MMTCE)

\begin{tabular}{cccc}
2002 & 2005 & 2010 & 2020 \\
\hline .106 & .337 & .781 & 1.644
\end{tabular}

Consumer Cost Savings (million \$)

\begin{tabular}{llll}
2002 & 2005 & 2010 & 2020 \\
\hline 35 & 119 & 349 & 740
\end{tabular}




\section{Space Conditioning and Refrigeration R\&D}

Equipment, Materials, and Tools Decision Unit

Residential HVAC Distribution Systems

This technology will reduce the energy liabilities of residential duct work.

\section{Performance Objective:}

- Displaced Technology: Current duct work.

- Performance Target: $20 \%$ reduction in heating and cooling loads.

\section{Market Penetration:}

- Market Introduction: 2002.

- Market Penetration Goal: $20 \%$ of new singlefamily units by 2020 .

\section{Advanced Electric Heat Pump Water Heaters} This technology involves the further development of a heat pump water heater with a dropin replacement capability. This improvement was assumed to increase sales of the heat pump water heater characterized in the Appliances and Emerging Technologies R\&D program by $20 \%$ starting in 2007.

\section{Performance Objective:}

- Displaced Technology: Current water heater technology.

- Performance Target: 2.47 energy factor.

\section{Market Penetration:}

- Target Market: Residential.

- Market Introduction: 2007.

- Market Penetration Goal: A 20\% increase in sales of heat pump hot water heaters.

\section{Commercial Refrigeration}

This program has been modeled as an advanced supermarket refrigeration system, which would target heating, cooling, and refrigeration end-use loads in the commercial food sales sector. These end uses comprise about $67 \%$ of total electrical end-use energy consumption and about $61 \%$ of total natural gas end-use energy consumption.
To calculate the energy savings for this program, the overall reduction in end-use energy consumption was applied to the estimated consumption per square foot within food sales buildings. This per-square-foot energy-savings level was aggregated to a program total based on a forecast of square feet of food sales buildings and an estimated market penetration curve. Specific input data are outlined below.

\section{Performance Objective:}

- Displaced Technology: Conventional refrigeration equipment in food sales buildings.

- Performance Target: Reduced energy for building HVAC and refrigeration equipment over the next 15 to 20 years, specifically, reduced energy use of at least $15 \%$ for supermarket refrigeration and HVAC energy use while reducing refrigerant needed.

Market Penetration:

- Target Market: All commercial food sales buildings.

- Market Introduction: 2001.

- Market Penetration Goal: 95\% penetration by 2020 and $100 \%$ by 2030 .

\section{Non-Energy Benefits:}

Reduced carbon emissions, economic benefits to private sector, reduced pollution from leaking refrigerant, and improved indoor air quality from better humidity control.

Program Strategy (\% of budget): (1)

- Research and Development - 100\%

- Market Transformation - 0\%

- Codes and Standards - 0\%.

\section{Sources:}

(1) FY 2002 Budget Request - Data Bucket Report for Space Conditioning and Refrigeration: Refrigeration Program (internal BTS document). 


\section{Appliances and Emerging Technologies}

Equipment, Materials, and Tools Decision Unit

\section{Program Objective: (1)}

The Appliances and Emerging Technologies R\&D program assists manufacturers and utilities in the commercializing highly efficient appliances and equipment with the following:

- Technology procurement to bring new products to market (late developmental work), which can bridge the gap between traditional $R \& D$ and mainstream deployment.

- For emerging technology products and Energy Star products with very low market penetration, independent third-party evaluation and verification of highly efficient products using field studies and demonstrations to increase market share.

- $R \& D$ on appliances that are not covered by other programs but that offer significant energy-savings potential.

The program also provides technical assistance and $R \& D$ on international issues and monitors international emerging technologies.

\section{Long-Term Goals: (1)}

The program's long-term goal is to establish a track record of commercializing highly efficient products that become entrenched in the mainstream market and that become the basis for other mechanisms, such as Energy Star or minimum efficiency standards.

\section{Market Segment:}

\section{Target Market}

- Market Description: Residential and commercial building products, with emphasis on appliances and water heating.

- Size of Market: Depends on the various equipment:

- Heat Pump Water Heater: About 13.6 million existing homes of the 36 million homes with electric resistance water heaters and about $40 \%$ of new homes. Limited, but initial market, for light commercial.

- Condensing Gas Water Heaters: About 20 million existing homes of the $>60$ million homes potential and about $40 \%$ of new homes.

- Dryers: About 57 million existing homes and about $80 \%$ of new dryer sales.

\section{Appliances and Emerg- ing Technologies R\&D}

Program Type:

Equipment Efficiency

Target Market:

All sectors, all climate zones

\section{End Uses:}

Water heaters, lighting, dryers, and space cooling

Unit of Measurement:

Efficiency of specific equipment type

Modeling Tool:

NEMS and Spreadsheets

Program Manager:

Jim Brodrick

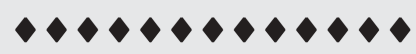

FY 2002 Benefits

Primary Energy Savings (TBtu)

\begin{tabular}{llll}
2002 & 2005 & 2010 & 2020 \\
\hline 5.1 & 12.9 & 30.8 & 78.3
\end{tabular}

Carbon Equivalent Reductions (MMTCE)

\begin{tabular}{cccc}
2002 & 2005 & 2010 & 2020 \\
\hline .098 & .236 & .514 & 1.346
\end{tabular}

Consumer Cost Savings (million \$)

\begin{tabular}{llll}
2002 & 2005 & 2010 & 2020 \\
\hline 36 & 94 & 258 & 662
\end{tabular}




\section{Appliance and Emerging Technologies}

Equipment, Materials, and Tools Decision Unit

\section{Methodology}

Several of the technologies were modeled using NEMS. The key inputs and outputs from the model are described below.

\section{Technology Assumptions}

Residential Can Lights

- Market Introduction: 2001.

- Performance Target: $75 \%$ energy savings (baseline 60-W incandescent relative to 15-W compact fluorescent light). Assumes 3 hr/day operation (49 kWh/fixture/yr).

- Size of Market: Projected sales of 21.8 million incandescent fixtures in FY 2002.

- Sales Target: $30 \%$ of sales in 2020.

This program was modeled in a spreadsheet using the above information.

\section{Subcompact Fluorescent Lights}

- Sales Target: 1.5 million sales/year in FY 2001, 2002, and 2003.

- Performance Target: Assumed efficacy of 70 lumens per watt.

- Installed Cost: $\$ 5 /$ compact fluorescent light. This program was modeled in a spreadsheet using the above information.

\section{Rooftop Air Conditioning}

- Market Introduction: 2004.

- Performance Target: $10 \%$ increase in efficiency.

- Sales Target: $10 \%$ of sales.

This program was modeled in a spreadsheet using the above information.

\section{Dryers}

- Market Introduction: 2005.

- Performance Target: $40 \%$ efficiency improvement.

- Installed Cost: \$75 over conventional.

Table 1 shows the NEMS inputs for electric clothes dryers, with the assumptions highlighted for the BTS-sponsored advanced dryer. While the equipment types are not identified by name, the table illustrates the

\begin{tabular}{|c|c|c|c|c|c|c|}
\hline \multicolumn{7}{|c|}{$\begin{array}{l}\text { Table 1. NEMS Residential Model Inputs for } \\
\text { Advanced Electric Clothes Dryers* }\end{array}$} \\
\hline \begin{tabular}{|c|} 
Equip \\
Model \\
Type
\end{tabular} & \begin{tabular}{|l|} 
Last \\
Year \\
Avail
\end{tabular} & Effic. & $\begin{array}{c}\text { Installed } \\
\text { Cost }\end{array}$ & \begin{tabular}{|l|} 
Logit \\
Model \\
Para: \\
Beta1 \\
\end{tabular} & $\begin{array}{l}\text { Logit } \\
\text { Model } \\
\text { Para: } \\
\text { Beta2 }\end{array}$ & \begin{tabular}{|c|} 
Implied \\
Discount \\
Rate
\end{tabular} \\
\hline 1 & 2020 & 3.01 & $\$ 333$ & -0.09 & -0.1 & 0.9 \\
\hline 2 & 2020 & 3.21 & $\$ 383$ & -0.09 & -0.1 & 0.9 \\
\hline $3 \mathrm{~A}$ & 2020 & \begin{tabular}{|l}
4.21 \\
\end{tabular} & $\$ 393$ & -0.09 & -0.1 & 0.9 \\
\hline $3 B$ & 2020 & \begin{tabular}{|l}
4.21 \\
\end{tabular} & $\$ 383$ & -0.09 & -0.1 & 0.9 \\
\hline $3 C$ & \begin{tabular}{|l|l}
2020 \\
\end{tabular} & \begin{tabular}{|l}
4.21 \\
\end{tabular} & $\$ 373$ & -0.09 & -0.1 & 0.9 \\
\hline
\end{tabular}

range of technologies competed within NEMS. The EIA base case includes two dryer technologies, but with second unit less than $10 \%$ more efficient than the base unit. The BTS program is assumed to introduce an advanced technology with an incremental efficiency improvement of $40 \%$ over the base unit.

The initial cost differential for the NEMS simulation was assumed to be $\$ 60$, slightly lower than the program target. (The NEMS model has an very high discount rate for electric dryers and, in this particular case, the presence of a radically new technology would possibly lower that effective rate. Instead of adjusting the discount rate, the equipment cost differential was reduced.) In 2010 and 2015, the cost differential is lowered further to spur increases in the market share of this technology.

Table 2 roughly indicates the market shares yielded by NEMS for the advanced electric dryers. In the standard version of the NEMS model, no single table summarized the national shares of sales by technology for dryers. Thus, the ranges reflect the results for the various market segments defined by census division

\begin{tabular}{|c|c|}
\hline \multicolumn{2}{|c|}{$\begin{array}{c}\text { Table 2. Market Share of Sales for } \\
\text { Advanced Electric Dryer }\end{array}$} \\
\hline Year & In All Housing Units (\%) \\
\hline 2005 & $3-5$ \\
\hline 2010 & $8-10$ \\
\hline 2020 & $15-20$ \\
\hline
\end{tabular}




\title{
Appliances and Emerging Technologies
}

\author{
Equipment, Materials, and Tools Decision Unit
}

and housing type. (For the water heater results shown in Tables 3 and 4, special coding was added to the model to derive national shares by technology.)

\section{Heat Pump Water Heater}

- Market Introduction: 2005.

- Performance Target: 2.47 energy factor (demonstrated).

- Sales Target: More aggressive sales target by 2015 (currently 6\%), possibly $10 \%$ (building codes expected to help by excluding electric resistance water heating, as will be case in California).

- Installed Cost: Initial installation cost of $\$ 700$, decreasing to $\$ 650$ in 2010.

The heat pump water heater and residential gas condensing water heater programs were modeled with NEMS. Table 3 shows the NEMS inputs for electric water heaters, with the BTS-sponsored heat pump water heater input assumptions highlighted. While the equipment types are not identified by name, the table illustrates the range of technologies competed within NEMS. Note that EIA assumes several levels of resistance water heaters with efficiencies ranging from 0.86 to

\begin{tabular}{|l|c|c|c|c|c|c|}
\hline \multicolumn{7}{|c|}{$\begin{array}{c}\text { Table 3. NEMS Residential Model Inputs for } \\
\text { High-Efficiency Heat Pump Water Heater }\end{array}$} \\
\hline $\begin{array}{c}\text { Equip. } \\
\text { Model } \\
\text { Type }\end{array}$ & $\begin{array}{c}\text { Last } \\
\text { Year } \\
\text { Avail }\end{array}$ & Effic. & $\begin{array}{c}\text { Installed } \\
\text { Cost }\end{array}$ & $\begin{array}{c}\text { Logit } \\
\text { Model } \\
\text { Para: } \\
\text { Beta1 }\end{array}$ & $\begin{array}{c}\text { Logit } \\
\text { Model } \\
\text { Para: } \\
\text { Beta2 }\end{array}$ & $\begin{array}{c}\text { Implied } \\
\text { Discount } \\
\text { Rate }\end{array}$ \\
\hline 7 & 2020 & 0.86 & $\$ 350$ & -0.01619 & -0.01952 & 0.83 \\
\hline 8 & 2020 & 0.88 & $\$ 350$ & -0.01619 & -0.01952 & 0.83 \\
\hline 9 & 2020 & 0.95 & $\$ 575$ & -0.01619 & -0.01952 & 0.83 \\
\hline 10 & 2020 & 2.60 & $\$ 1,025$ & -0.01619 & -0.01952 & 0.83 \\
\hline 11 & 2020 & 2.00 & $\$ 2,600$ & -0.01619 & -0.01952 & 0.83 \\
\hline 12 & 2020 & 0.89 & $\$ 350$ & -0.01619 & -0.01952 & 0.83 \\
\hline 13 & 2020 & 0.96 & $\$ 475$ & -0.01619 & -0.01952 & 0.83 \\
\hline 14 & 2020 & 2.47 & $\$ 700$ & -0.01619 & -0.01952 & 0.83 \\
\hline 15 & 2020 & 0.90 & $\$ 400$ & -0.01619 & -0.01952 & 0.83 \\
\hline 16 & 2020 & 0.96 & $\$ 425$ & -0.01619 & -0.01952 & 0.83 \\
\hline 17 & 2020 & 2.47 & $\$ 650$ & -0.01619 & -0.01952 & 0.83 \\
\hline Highlighted cells indicate BTS programs. & \\
\hline
\end{tabular}

0.96. The very high-efficiency water heaters in the EIA base case are very costly.

Table 4 shows the penetration of the BTSsponsored heat pump water heater for sales to new homes and for replacement of existing electric water heaters. In the first few years of the programs, NEMS projected the market share to be $\sim 1 \%$. After the assumed $\$ 50$ cost reduction in 2010, the market share increases to a little more than 3\%. These low shares are largely attributed to the high discount rate used in NEMS. As shown in the last column of Table 4 , the value of the discount rate for electric water heaters was assumed to be over $80 \%$. Thus, in spite of the performance differential for the heat pump unit, the higher first cost was assumed to be a large barrier in promoting widespread adoption of this technology.

\begin{tabular}{|c|l|l|l|l|}
\hline \multicolumn{5}{|c|}{$\begin{array}{c}\text { Table 4. NEMS-Generated Penetration Rates for } \\
\text { High-Efficiencv Heat Pump Water Heaters }\end{array}$} \\
\hline Year & $\begin{array}{c}\text { In New } \\
\text { Housina } \\
\text { Units }\end{array}$ & $\begin{array}{c}\text { Fraction } \\
\text { of Electric } \\
\text { WH }\end{array}$ & $\begin{array}{c}\text { Replace. } \\
\text { Units }\end{array}$ & $\begin{array}{c}\text { Fraction of } \\
\text { Electric } \\
\text { WH }\end{array}$ \\
\hline 2005 & 7,325 & 0.011 & 26,435 & 0.012 \\
\hline 2006 & 7,374 & 0.011 & 27,020 & 0.012 \\
\hline 2007 & 7,461 & 0.011 & 27,343 & 0.012 \\
\hline 2008 & 7,345 & 0.011 & 27,507 & 0.012 \\
\hline 2009 & 7,142 & 0.010 & 27,861 & 0.012 \\
\hline 2010 & 22,773 & 0.033 & 90,881 & 0.037 \\
\hline 2015 & 18,268 & 0.026 & 73,876 & 0.029 \\
\hline 2020 & 17,515 & 0.025 & 74,509 & 0.028 \\
\hline
\end{tabular}

Several other points should be made with regard to the model-generated penetrations shown in Table 4. NEMS has no technology diffusion algorithm that will produce a gradual increase in market shares without any change in cost and performance. Thus, the market shares from 2005 through 2010 are virtually the same. It can be argued that the model provides an average penetration that yields the same level of total sales as would an s-shaped penetration curve. A second point relates to the dedine in the shares in the out years, 2015 and 2020. This result stems entirely from the 


\section{Appliances and Emerging Technologies}

Equipment, Materials, and Tools Decision Unit

reductions in cost assumed for the resistance water heater assumed in the base case.

Table 5 shows the NEMS inputs for gas water heaters, with the input assumptions highlighted for the BTS-sponsored condensing water heaters. Again, while the equipment types are not identified by name, the table illustrates the range of technologies competed within NEMS. Note that EIA assumes several levels of gas water heaters (noncondensing) with efficiencies ranging from 0.54 to 0.70 . With an efficiency of 0.86 , the condensing water heaters in the EIA base case are very costly.

\begin{tabular}{|l|c|c|c|c|c|c|}
\hline \multicolumn{6}{|c|}{ Table 5. NEMS-Generated Inputs for Gas Water Heaters } \\
\hline $\begin{array}{c}\text { Equip } \\
\text { Model } \\
\text { Type }\end{array}$ & $\begin{array}{c}\text { Last } \\
\text { Year } \\
\text { Avail }\end{array}$ & Effic. & $\begin{array}{c}\text { Installed } \\
\text { Cost }\end{array}$ & $\begin{array}{c}\text { Loqit } \\
\text { Model } \\
\text { Para: } \\
\text { Beta1 }\end{array}$ & $\begin{array}{c}\text { Logit } \\
\text { Model } \\
\text { Para: } \\
\text { Beta2 }\end{array}$ & $\begin{array}{c}\text { Implied } \\
\text { Discount } \\
\text { Rate }\end{array}$ \\
\hline 1 & 2020 & 0.54 & $\$ 340$ & -0.05393 & -0.1136 & 0.47 \\
\hline 2 & 2020 & 0.58 & $\$ 370$ & -0.05393 & -0.1136 & 0.47 \\
\hline 3 & 2004 & 0.6 & $\$ 400$ & -0.05393 & -0.1136 & 0.47 \\
\hline 3 & 2020 & 0.6 & $\$ 375$ & -0.05393 & -0.1136 & 0.47 \\
\hline 4 & 2004 & 0.86 & $\$ 2,360$ & -0.05393 & -0.1136 & 0.47 \\
\hline 4 & 2014 & 0.86 & $\$ 2,000$ & -0.05393 & -0.1136 & 0.47 \\
\hline 4 & 2020 & 0.86 & $\$ 1,800$ & -0.05393 & -0.1136 & 0.47 \\
\hline 5 & 2014 & 0.63 & $\$ 450$ & -0.05393 & -0.1136 & 0.47 \\
\hline 5 & 2020 & 0.63 & $\$ 425$ & -0.05393 & -0.1136 & 0.47 \\
\hline 6 & 2020 & 0.7 & $\$ 500$ & -0.05393 & -0.1136 & 0.47 \\
\hline 26 & 2020 & 0.8 & $\$ 500$ & -0.05393 & -0.1136 & 0.47 \\
\hline 27 & 2020 & 0.8 & $\$ 475$ & -0.05393 & -0.1136 & 0.47 \\
\hline Highlighted cells indicate BTS programs. \\
\hline
\end{tabular}

Residential Gas Condensing Water Heater

- Market Introduction: 2002.

- Performance Target: Energy factor of 0.80 .

- Penetration Target: $9 \%$ to $10 \%$ by 2020 .

- Installed Cost: Assumes $\$ 350$ base cost; new water heating will have an incremental cost of $\$ 150$ to $\$ 200$.

Table 6 shows the penetration of the BTSsponsored condensing gas water heaters for sales to new homes and for replacements of existing gas water heaters. In the first few years of the programs, NEMS projected the market share to be $\sim 2 \%$. After the assumed
$\$ 25$ cost reduction in 2010, the market share increases to about $6 \%$ in new homes and over $7 \%$ for replacement units. These low shares are largely attributed to the high discount rate used in NEMS. As the last column of Table 4 shows, the value of the discount rate for gas water heaters was assumed to be nearly $50 \%$. The behavior of the predicted shares for this technology is similar to that of the heat pump water heater. The shares fall slightly over the full forecast period as the cost and performance of competing (noncondensing) water heaters improve.

\begin{tabular}{|c|c|c|c|c|}
\hline \multicolumn{5}{|c|}{ Table 6. Sales Penetration for Condensing } \\
Gas Water Heater \\
\hline Year & $\begin{array}{c}\text { In New } \\
\text { Housing } \\
\text { Units }\end{array}$ & $\begin{array}{c}\text { Fraction } \\
\text { of Gas } \\
\text { WH }\end{array}$ & $\begin{array}{c}\text { Replace. } \\
\text { Units }\end{array}$ & $\begin{array}{c}\text { Fraction } \\
\text { of Gas } \\
\text { WH }\end{array}$ \\
\hline 2003 & 19,424 & 0.019 & 60,336 & 0.019 \\
\hline 2004 & 19,481 & 0.019 & 62,811 & 0.020 \\
\hline 2005 & 15,445 & 0.014 & 48,305 & 0.015 \\
\hline 2010 & 60,035 & 0.056 & 234,092 & 0.071 \\
\hline 2015 & 55,912 & 0.054 & 233,794 & 0.068 \\
\hline 2020 & 46,945 & 0.046 & 230,349 & 0.059 \\
\hline
\end{tabular}

\section{Non-Energy Benefits:}

Environmental savings, savings from water conservation devices and high-efficiency appliances. (These benefits are being better characterized and will be used to justify water/waste water utilities implementing demand-side management programs.)

\section{Program Strategy:}

- Research and Development - 50\%

- Market Transformation - 50\%

- Codes and Standards - 0\%.

\section{Sources:}

(1) FY 2002 Budget Request - Data Bucket Report for Appliances and Emerging Technology Program (internal BTS document). 


\section{Building Envelope R\&D: Electrochromic Windows}

Equipment, Materials, and Tools Decision Unit

\section{Program Objective: (1)}

This program develops commercially viable advanced electrochromic windows using competing producers. With a focus on electrochromic research, the program's objective is to reward the marketplace for industry's investments in the research, development, and deployment of energy-efficient windows.

In an area that is less suited to national standards and that has a growing international market, significant investments are required to establish a technical basis for performance standards recognized for their scientific excellence. On this basis, the program helps develop the credible rating and certification programs and the design tools to develop and apply efficient windows. One program objective is to double the average energy efficiency of windows sold and establish universal NFRC (National Fenestration Rating Council) ratings based on credible International Standards Organization (ISO) standards.

\section{Long-Term Goals: ${ }^{(1)}$}

- National: Change windows from net energy loss to net energy benefits across the United States.

- Current Energy Losses: 3.2 quad.

- Environmental Impact: 64 MMtons carbon/yr.

- Industry: Strengthen market position of U.S. industry in global markets.

- Owners: Provide cost-effective savings with comfort, productivity, and amenity.

\section{Market Segment:}

Performance Objective:

- Displaced Technology: Conventional doubleglazed, low-emissivity windows.

- Performance Target: Reduction in unwanted heat gains and losses and perimeter lighting. Estimated savings per building will be determined by simulating all commercial building types in all dimate zones.

- Performance Parameters: See the following table.

\section{Target Market}

- Market Description: (1) New and existing commercial building types in all climate zones.

- Size of Market: About 55 million manufactured units sold each year, for residential and light commercial.

\section{Building Envelope R\&D: Electrochromic Windows}

Program Type:

Envelope

Target Market:

All commercial buildings in all climate zones

\section{End Uses:}

Windows

\section{Unit of Measurement:}

$\%$ load reduction per square foot (commercial)

Modeling Tool:

NEMS

Program Manager:

Sam Taylor

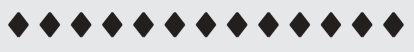

FY 2002 Benefits Primary Energy Savings (TBtu) \begin{tabular}{llll}
2002 & 2005 & 2010 & 2020 \\
\hline 2.7 & 8.0 & 17.8 & 59.9
\end{tabular}

Carbon Equivalent Reductions (MMTCE)

\begin{tabular}{llll}
2002 & 2005 & 2010 & 2020 \\
\hline .052 & .149 & .305 & 1.089
\end{tabular}

Consumer Cost Savings (million \$)

\begin{tabular}{llll}
2002 & 2005 & 2010 & 2020 \\
\hline 17 & 52 & 137 & 482
\end{tabular}




\section{Building Envelope R\&D: Electrochromic Windows}

Equipment, Materials, and Tools Decision Unit

\begin{tabular}{|l|l|}
\hline \multicolumn{1}{|c|}{ Parameter } & \multicolumn{1}{c|}{ Value } \\
\hline $\begin{array}{l}\text { Maximum Shading } \\
\text { Coefficient }\end{array}$ & 0.4 (heating) \\
\hline $\begin{array}{l}\text { Minimum Shading } \\
\text { Coefficient }\end{array}$ & 0.1 (cooling) \\
\hline U-value & 0.25 Btu/h $\cdot \mathrm{ft}^{20} \mathrm{~F}$ \\
\hline Lighting Reduction & $\begin{array}{l}30 \% \text { of lighting } \\
\text { energy }\end{array}$ \\
\hline
\end{tabular}

- Market Introduction: Program began before 1977; the market introduction is targeted for the end of FY 2002 for electrochromic windows in commercial applications.

- Market Penetration Goal: See table below.

\begin{tabular}{|c|c|c|c|c|c|}
\hline \multicolumn{6}{|c|}{ Rate of Penetration (\% of annual sales) } \\
\hline Building Type & Vintage & Region & $\begin{array}{c}\mathbf{2 0 0 5} \\
(\%)\end{array}$ & $\begin{array}{c}\mathbf{2 0 2 0} \\
(\%)\end{array}$ & $\begin{array}{c}\mathbf{2 0 3 0} \\
(\%)\end{array}$ \\
\hline All Commercial & New & All & 2 & 20 & 50 \\
\hline All Commercial & Existing & All & 1.8 & 17.2 & 43.2 \\
\hline
\end{tabular}

\section{Non-Energy Benefits: (1)}

Potential for reducing both utility and building peak loads, which allow for reduced HVAC requirements and thus, lower first costs, which can offset increased high-performance glazing costs. Other benefits include environmental benefits, particularly from reduced utility peak loads, comfort, and aesthetics.

\section{Program/Technology Consumer Costs:}

- Incremental Cost of BTS Technology: $+\$ 5 / \mathrm{sq}$ ft for electrochromic windows compared with conventional, doubleglazed, low-emissivity windows.

\section{Sources:}

(1) FY 2002 Budget Request - Data Bucket Report for Building Envelope: Windows Program (internal BTS document). 


\section{Building Envelope R\&D: Superwindows}

Equipment, Materials, and Tools Decision Unit

\section{Program Objective: (1)}

The program's objective is to reward industry for its investments in the research, development, and deployment of energy efficient windows. In an area that that has a growing international market, significant investments are required to establish a technical basis for performance standards that is recognized for its scientific excellence.

On this basis, the program helps develop the credible rating and certification programs and the design tools to develop and apply efficient windows. The program is developing commercially viable advanced technologies from competing producers and providing research support to Energy Star and Efficient Window Collaborative programs. One program objective is to double the average energy efficiency of windows sold and establish universal NFRC (National Fenestration Rating Council) ratings based on credible International Standards Organization (ISO) standards.

\section{Long-Term Goals: (1)}

- National: Change windows from net energy loss to net energy benefits across the United States.

- Current Energy Losses: 3.2 quad

- Environmental Impact: $64 \mathrm{MM}$ tons carbon/yr.

- Industry: Strengthen market position of U.S. industry in global markets.

- Owners: Provide cost-effective savings with comfort, productivity, and amenity.

\section{Market Segment:}

\section{Performance Objective:}

- Displaced Technology: Conventional doubleglazed, low-emissivity windows with a U-value of 0.4 $\mathrm{Btu} / \mathrm{h} \cdot \mathrm{ft}^{2}$ oF and a shading coefficient of .55 .

- Performance Target: Reduce unwanted heat gains and losses. The estimated savings per building will be determined by simulating residential buildings in all climate zones.

- Performance Parameters: Two superwindow technologies will be used: northern superwindows in heating dominated climates (heating-degree days >4000) and southern superwindows in cooling dominated climates (heating-degree days $<4000$ ). See the table below.
Building Envelope R\&D: Superwindows

Program Type:

Envelope

Target Market:

All residential buildings, all climate zones

End Uses:

Windows

Unit of Measurement:

$\%$ load reduction per unit (residential)

Modeling Tool: Spreadsheet

Program Manager:

Sam Taylor

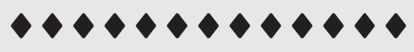

FY 2002 Benefits

Primary Energy Savings (TBtu)

\begin{tabular}{llll}
2002 & 2005 & 2010 & 2020 \\
\hline 0.0 & 10.7 & 52.7 & 254.1
\end{tabular}

Carbon Equivalent Reductions (MMTCE)

\begin{tabular}{llll}
2002 & 2005 & 2010 & 2020 \\
\hline .000 & .176 & .839 & 4.089
\end{tabular}

Consumer Cost Savings (million \$)

\begin{tabular}{llll}
2002 & 2005 & 2010 & 2020 \\
\hline 0 & 75 & 390 & 1885
\end{tabular}




\section{Building Envelope R\&D: Superwindows}

Equipment, Materials, and Tools Decision Unit

\begin{tabular}{|c|c|c|}
\hline Window & Parameter & Value \\
\hline \multirow[t]{2}{*}{$\begin{array}{l}\text { Northern } \\
\text { Superwindow }\end{array}$} & $\begin{array}{l}\text { Shading } \\
\text { Coefficient }\end{array}$ & $\begin{array}{l}0.7 \text { (heating season) } \\
0.3 \text { (cooling season) }\end{array}$ \\
\hline & U-value & $0.1 \mathrm{Btu} / \mathrm{h} \cdot \mathrm{ft}^{2}{ }^{2} \mathrm{~F}$ \\
\hline \multirow[t]{2}{*}{$\begin{array}{l}\text { Southern } \\
\text { Superwindow }\end{array}$} & $\begin{array}{l}\text { Shading } \\
\text { Coefficient }\end{array}$ & 0.15 (all seasons) \\
\hline & U-value & $0.2 \mathrm{Btu} / \mathrm{h} \cdot \mathrm{ft}^{2}{ }^{2} \mathrm{~F}$ \\
\hline
\end{tabular}

\section{Target Market}

- Market Description: ${ }^{(1)} \mathrm{New}$ and existing residential units in all climate zones.

- Size of Market: ${ }^{(1)}$ About 55 million manufactured units sold each year for residential and light commercial.

- Market Introduction: The program began before 1977; advanced window collaborative and advanced spectrally selective glazing are targeted for market introduction in FY 2003.

\section{Non-Energy Benefits:}

Environmental benefits, particularly from reduced utility peak loads, comfort, aesthetics, etc.

\section{Program/Technology Consumer Costs:}

- Incremental Cost of BTS Technology: $+\$ 6 / \mathrm{sq} f \mathrm{ft}$ in 2005, +\$4/sq ft in 2020, and \$3/ sq ft in 2030 for advanced windows over conventional double-glazed, low-emissivity windows.

\section{Sources:}

(1) FY 2002 Budget Request - Data Bucket Report for Building Envel ope: Windows Program (internal BTS document).

- Market Penetration Goal: See table bel ow.

\begin{tabular}{|c|c|c|c|c|c|}
\hline \multicolumn{6}{|c|}{ Rate of Penetration (\% of annual sales) } \\
\hline $\begin{array}{c}\text { Building } \\
\text { Type }\end{array}$ & Vintage & Region & $\mathbf{2 0 0 5}$ & $\mathbf{2 0 2 0}$ & $\mathbf{2 0 3 0}$ \\
\hline Residential & New & All & 3 & 65 & 85 \\
\hline Residential & Existing & All? & 1.5 & 33 & 43.2 \\
\hline
\end{tabular}




\section{Building Envelope R\&D: Thermal Insulation and Building Materials}

Equipment, Materials, and Tools Decision Unit

\section{Program Objective: (1)}

This program improves envelope performance through advanced technology and increased understanding of the basic processes governing envelope performance. Building envelopes, which influence electric lighting requirements, are the primary factor governing the heating, cooling, and ventilation requirements of buildings. Because building envelopes impact $53 \%$ of building energy use, substantial energy can be saved by improving the materials, components, and systems that make up building envelopes.

This program performs research on energy-efficient, sustainable, low-cost, and super-smart thermal insulation and building envelope materials and structures. The program develops laboratory, analytical, and field experiments and methodologies to characterize tools and testing for new or improved materials and systems. The program also provides accurate evaluation procedures.

\section{Long-Term Goal: (1)}

The program's long term goal is to develop new building materials and systems that can contribute to DOE's energy-efficiency goal of reducing annual building energy consumption by 2 quad by 2010 and 5 quad by 2020; that are cost-competitive for their application; and that are as environmentally benign and sustainable as possible. Another long-term goal of the program involves developing a fundamental understanding of heat, air, and moisture transfer through building envelopes and insulation materials and applying the results to develop construction technologies to increase building energy efficiency.

\section{Market Segment:}

\section{Performance Objective:}

- Displaced Technology: Conventional wall insulation and framing.

- Performance Target: Reduce unwanted heat gains and losses and perimeter lighting. Estimated savings per building are determined by simulating food sales, mercantile and service, warehouse, and other commercial building types and single-family residential buildings in all climate zones. National impacts will be determined in NEMS as shown in the following table.
Building Envelope R\&D: Thermal Insulation and Building Materials

Program Type:

Envelope

Target Market:

All sectors in all climate zones

End Uses:

Roofs and insulation

Unit of Measurement:

\% load reduction per unit (residential) and \% load reduction per square foot (commercial)

Modeling Tool:

NEMS Envelope

Program Manager:

Arun Vohra

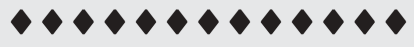

FY 2002 Benefits

Primary Energy Savings (TBtu)

\begin{tabular}{llll}
2002 & 2005 & 2010 & 2020 \\
\hline 0.0 & 0.1 & 1.0 & 18.1
\end{tabular}

\section{Carbon Equivalent Reductions (MMTCE)}

\begin{tabular}{llll}
2002 & 2005 & 2010 & 2020 \\
\hline .000 & .001 & .016 & .276
\end{tabular}

Consumer Cost Savings (million \$)

\begin{tabular}{llll}
2002 & 2005 & 2010 & 2020 \\
\hline 0 & 1 & 7 & 109
\end{tabular}




\section{Building Envelope R\&D: Thermal Insulation and Building Materials}

Equipment, Materials, and Tools Decision Unit

\begin{tabular}{|l|l|c|}
\hline Parameter & Value & Units \\
\hline $\mathrm{r}$-value & 36 & $\mathrm{Btu} / \mathrm{h}^{\prime} \mathrm{ft}^{2}{ }^{\circ} \mathrm{F}$ \\
\hline
\end{tabular}

\section{Target Market}

- Market Description: (1) New residential and commercial buildings. Certain elements of the program focus on retrofit strategies as well. The program activities are independent of region and household income.

- Size of Market: ${ }^{(1)}$ All new and retrofit residential and commercial construction and all building categories.

\section{Methodology}

For FY 2001, this program was represented by advanced insulations and R30 insulation/30-year life roofs technologies. For FY 2002, this program was recharacterized using the quick fill walls and 30/30 roofs technologies, which are summarized below.

\section{Quick Fill Walls}

Description: This technology involves applying environmental wall-insulating techniques.

\section{Performance Objective:}

- Displaced Technology: Conventional wall insulation and framing.

- Performance Target: Reduce unwanted heat gains and losses and perimeter lighting. Estimated savings per building are determined by simulating food sales, mercantile and service, warehouse, and other commercial building types and single-family residential buildings in all climate zones.

- Performance Parameters: See the table below.

\begin{tabular}{|l|c|}
\hline Parameter & Value \\
\hline r-value & $36 \mathrm{Btu} / \mathrm{h} \cdot \mathrm{ft}^{2}{ }^{\circ} \mathrm{F}$ \\
\hline
\end{tabular}

Market Penetration:

- Target Market: Selected commercial and residential buildings in all climate zones.

- Market Introduction: 2004.
- Market Penetration Goal: See table below.

\begin{tabular}{|l|c|c|c|c|}
\hline \multicolumn{5}{|c|}{$\begin{array}{l}\text { Rate of Penetration } \\
\text { (\% of annual sales) }\end{array}$} \\
\hline $\begin{array}{c}\text { Building } \\
\text { Type }\end{array}$ & Vintage & Region & $\begin{array}{c}\mathbf{2 0 1 0} \\
\text { (\%) }\end{array}$ & $\begin{array}{c}\mathbf{2 0 3 0} \\
\text { (\%) }\end{array}$ \\
\hline $\begin{array}{l}\text { Food Sales, } \\
\text { Mercantile } \\
\text { and Service, } \\
\text { Warehouse, } \\
\text { and Other }\end{array}$ & New & All & 1.5 & 7.6 \\
\hline Residential & New & All & 2.3 & 11.5 \\
\hline
\end{tabular}

\section{R30 Insulation/30-Year Life Roofs}

Description: This technology involves applying advanced roofing techniques.

\section{Performance Objective:}

- Displaced Technology: Conventional commercial low-slope roofs.

- Performance Target: Reduced unwanted heat gains and losses and perimeter lighting. Estimated savings per building will be determined by simulating all commercial building types in all climate zones. National impacts will be determined in NEMS.

- Performance Parameters: See the table below.

\begin{tabular}{|l|c|}
\hline Parameter & Value \\
\hline r-value & $36 \mathrm{Btu} / \mathrm{h} \cdot \mathrm{ft}^{2} \mathrm{~F}$ \\
\hline
\end{tabular}

Market Penetration:

- Target Market: All sectors in all climate zones.

- Market Introduction: 2010.

- Market Penetration Goal: See the table below.

\begin{tabular}{|l|c|c|c|c|}
\hline \multicolumn{5}{|c|}{ Rate of Penetration (\% of annual sales) } \\
\hline Building Type & Vintage & Region & $\begin{array}{c}\mathbf{2 0 1 0} \\
\text { (\%) }\end{array}$ & $\begin{array}{c}\mathbf{2 0 3 0} \\
\text { (\%) }\end{array}$ \\
\hline All Commercial & New & All & 0.6 & 50.5 \\
\hline All Commercial & Existing & All & 0.4 & 30.2 \\
\hline
\end{tabular}




\section{Building Envelope R\&D: Thermal Insulation and Building Materials}

Equipment, Materials, and Tools Decision Unit

Non-Energy Benefits: (1)

Reduced construction and demolition waste; use of natural, recycled and byproduct materials; reduced $\mathrm{CO}_{2}$ emissions from improved energy efficiency; increased housing affordability from reduced energy consumption; improved comfort and indoor air quality from more moisture tolerant designs and controls; and increased global competitiveness of U.S. industry.
Program Strategy (\% of budget): (1)

- Research and Development - 95\%

- Market Transformation - 0\%

- Codes and Standards - 5\%.

\section{Sources:}

(1) FY 2002 Budget Request - Data Bucket Report for Building Envelope: Thermal Insulation and Buildings Materials Program (internal BTS document). 


\section{Analysis Tools and Design Strategies}

Equipment, Materials, and Tools Decision Unit

\section{Program Objective:(1)}

The Analysis Tools and Design Strategies program researches the interrelationship of energy systems and buildings energy performance, develops various building analysis tools to more accurately model energy use in new and existing buildings, and provides recommendations and strategies to cost effectively lower energy use and improve building performance. The program focuses on whole-building software tools for evaluating energy efficiency and renewable energy. The program also focuses on non-software solutions such as improved standards, guidelines, and performance measurements, all of which bring about excellence in designing new buildings.

\section{Long-Term Goal:(1)}

The program's long-term goal is to improve energy designs for all building types through a suite of widely used analytical tools and guidance documents.

\section{Market Segment:}

\section{Performance Objective:}

- Displaced Technology: Conventional design/building practice.

- Performance Target: Reduce heating and cooling loads by 30\% in new construction by 2020 .

\section{Target Market}

- Market Description: All new commercial and residential construction (particularly buildings with energy-use intensities $>50 \%$ of the average energy-use intensity).

- Size of Market: New, single-family, multifamily, and mobile homes for the residential sector and assembly, education, food service, food sales, health care, lodging, mercantile and service, and office buildings for the commercial sector.

- Market Introduction: 1996.

- Market Penetration Goal: By 2020 penetrate $4 \%$ of new commercial and multifamily construction in combination with Commercial Buildings R\&D program and $5 \%$ of new singlefamily and mobile home units.

\section{Methodology}

Analysis tools save energy by simulating the adoption of efficient technologies in the design stage of new con-

\section{Analysis Tools and Design Strategies}

Program Type:

Whole Building

Target Market:

Single-family and manufactured homeowners with $>\$ 50,000 / y r$ income, all multifamily and commercial sector and industrial offices in all climate zones

End Uses:

All end uses and all fuel types

Unit of Measurement:

$\%$ load reduction per unit (residential) and \% load reduction per square foot (commercial)

Modeling Tool:

NEMS

Program Manager:

Dru Crawley

$\bullet \bullet \bullet \bullet \bullet \bullet \bullet \bullet \bullet \bullet \bullet$

FY 2002 Benefits

Primary Energy Savings (TBtu)

\begin{tabular}{llll}
2002 & 2005 & 2010 & 2020 \\
\hline 0.0 & 0.0 & 0.5 & 6.5
\end{tabular}

Carbon Equivalent Reductions (MMTCE)

\begin{tabular}{llll}
2002 & 2005 & 2010 & 2020 \\
\hline .000 & .000 & .008 & .107
\end{tabular}

Consumer Cost Savings (million \$)

\begin{tabular}{llll}
2002 & 2005 & 2010 & 2020 \\
\hline 0 & 0 & 4 & 51
\end{tabular}




\section{Analysis Tools and Design Strategies}

Equipment, Materials, and Tools Decision Unit

struction and major renovation. Program savings will be modeled from the adoption of technologies for reducing space heating and cooling loads.

\section{Non-Energy Benefits: ${ }^{(1)}$}

Improved indoor environmental quality such as thermal comfort and ventilation adequacy and improved indoor air quality, fire safety, and overall environmental sustainability (i.e., Green Buildings).

\section{Program Strategy (\% of budget): ${ }^{(1)}$}

- Research and Development - 90\%

- Market Transformation - $10 \%$

- Codes and Standards - 0\%.

\section{Sources:}

(1) FY 2002 Budget Request - Data Bucket Report for Analysis Tools and Design Strategies Program (internal BTS document).

(2) Building Technology, State and Community Programs F unding Profile for the FY 2002 Corporate Review Budget (internal BTS document). 


\section{Lighting and Appliance Standards}

Equipment, Materials, and Tools Decision Unit

\section{Program Objective:(1)}

The Lighting and Appliance Standards program achieves significant energy savings, consumer cost savings, and reduced air emissions through standards rulemaking. The program also prescribes test procedures that measure energy efficiency and energy use and that estimate the annual operating cost of each appliance.

\section{Long-Term Goal:(1)}

The program's long-term goal is to set efficiency standards that lead to substantial increases in the average efficiency of new building equipment.

\section{Market Segment:}

\section{Target Market}

- Market Description: All residential and commercial equipment covered by the appropriate legislation. ${ }^{(2,3)}$

- Size of Market: All residential and commercial equipment in the market.

\section{Methodology}

For FY 2002, the energy savings from equipment standards activities were primarily based on a PNNL developed spreadsheet to support an EPAct screening analysis conducted in late 1999 and early 2000. This spreadsheet was used to estimate the energy savings from various levels of standards for nearly 40 types of equipment covered by EPAct. The spreadsheet results were used to identify products that could achieve significant energy savings beyond the efficiency levels set in the recent ASHRAE 90.1-1999 publication. ${ }^{(4)}$

For FY 2002, the EPAct standards were assumed to continue with the products having the potential for additional energy savings. These products include boilers, three-phase residential-size cooling equipment, packaged terminal air conditioning, packaged terminal heat pump equipment, and large rooftop air-conditioning equipment. Energy-savings' estimates for these products based on the spreadsheet are shown in the next section.

The FY 2002 savings for this program also include an estimate for revised standards for residential gas furnaces. This program was modeled in the NEMS residential model. In the baseline version of the model used by EIA for its Annual Energy Outlook 2000, a wide range of

\section{Lighting and Appliance Standards}

Program Type:

Codes and standards for equipment efficiency

Target Market:

All sectors and all climate zones

End Uses:

All end uses and all fuel types

Unit of Measurement:

Efficiency of specific equipment

Modeling Tool:

NEMS

Spreadsheet

Program Manager:

Carl Adams

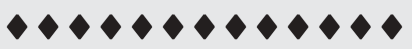

FY 2002 Benefits

Primary Energy Savings (TBtu)

\begin{tabular}{llll}
2002 & 2005 & 2010 & 2020 \\
\hline 0.0 & 4.8 & 70.6 & 269.3
\end{tabular}

Carbon Equivalent Reductions (MMTCE)

\begin{tabular}{llll}
2002 & 2005 & 2010 & 2020 \\
\hline .000 & .089 & 1.176 & 4.685
\end{tabular}

Consumer Cost Savings (million \$)

\begin{tabular}{llll}
2002 & 2005 & 2010 & 2020 \\
\hline 0 & 31 & 522 & 2051
\end{tabular}




\section{Lighting and Appliance Standards}

Equipment, Materials, and Tools Decision Unit

the furnace efficiencies was available: $78 \%$, $80 \%, 84 \%, 88 \%$, and $96 \%$. To estimate the standards program for furnaces, the lowest two efficiency levels were assumed to not meet the revised standard after 2007. In addition, savings related to standards covering distribution transformers were calculated in a spreadsheet based on a 1992 study conducted by Geller and Nadel.(5)

\section{Estimated Savings for Commercial Products:} Based on the spreadsheet EPACT_SA.XLS (essentially identical to the spreadsheet installed on the BTS web site for public comment subsequent to the EPAct screening analysis), the following tables summarize the efficiency assumptions and energy savings results for products that will undergo further analysis by DOE/ BTS. Table 1 summarizes the key assumptions and results for 13 cooling products, and Table 2 does the same for boilers and a high-capacity instantaneous water heater. Cumulative savings, shown in the last column in both tables, are based on the savings from the effective date of the standards through 2030.

\section{Estimated Savings for Distribution Transformers:}

Distribution transformers convert highvoltage electricity from distribution centers to lower-voltage electricity for use at the household level. During this conversion process, a small fraction of heat is lost. Rules are being written to reduce the amount of heat loss during this conversion process.

Savings' estimates for a distribution transformer standard are based on a study conducted by Geller and Nadel. . $^{(5)}$ The study assumed the following:

- Savings of 80 watts per unit

- Annual sales of 1.2 million units

- $20 \%$ sales complying with the new level

- without the standard

- 8,760 annual operating hours per unit

- 13-year life of equipment.

The savings estimate of 80 watts per unit installed is multiplied by the estimated hours of operation and then by the forecasted number of units installed.

\section{Estimated Savings for Residential Gas Furnaces:}

Rules related to the efficiency of residential gas furnaces are being written with the anticipated adoption date of 2008.

Savings for residential gas furnaces are estimated using NEMS and the following assumptions:

- Proposed residential gas furnace efficiency of $82 \%$ annual fuel utilization efficiency

\begin{tabular}{|c|c|c|c|c|c|c|c|c|}
\hline \multicolumn{7}{|c|}{ Table 1. Key Assumptions and Results for Cooling Products } \\
\hline & \multicolumn{3}{|c|}{$\begin{array}{c}\text { Efficiency } \\
\text { (SEER and EER) }\end{array}$} & \multicolumn{3}{|c|}{$\begin{array}{c}\text { Energy Savings by Year } \\
\text { (TBtu) }\end{array}$} \\
\hline Equipment Category & $\begin{array}{c}\text { EPAct } \\
\mathbf{9 2}\end{array}$ & $\begin{array}{c}\text { New } \\
\text { Std }\end{array}$ & $\begin{array}{c}\text { Eff. } \\
\text { Date }\end{array}$ & $\mathbf{2 0 1 0}$ & $\mathbf{2 0 2 0}$ & $\mathbf{2 0 3 0}$ & Cum. \\
\hline 3-Phase Single Package, Air Source Air Conditioning, $<65 \mathrm{kBtu} / \mathrm{h}$ & 9.7 & 12 & 2005 & 4.6 & 21.0 & 26.5 & 396.0 \\
\hline 3-Phase Single Package, Air Source Heat Pump, $<65 \mathrm{kBtu} / \mathrm{h}$ & 9.7 & 12 & 2005 & 1.2 & 3.1 & 3.4 & 60.2 \\
\hline 3-Phase Split, Air Source Air Conditioning, <65 kBtu/h & 9.7 & 11 & 2005 & 0.9 & 4.1 & 5.2 & 78.1 \\
\hline 3-Phase Split, Air Source Heat Pump, <65 kBtu/h & 9.7 & 12 & 2005 & 9.1 & 24.0 & 26.5 & 463.0 \\
\hline Central, Water Source Heat Pump, $>17$ and $<65 \mathrm{kBtu} / \mathrm{h}$ & 9.3 & 12.5 & 2008 & 1.5 & 7.1 & 11.1 & 146.9 \\
\hline Central, Air Source Air Conditioning, >=65 and <135 kBtu/h & 8.9 & 11 & 2008 & 5.5 & 25.0 & 31.6 & 471.6 \\
\hline Central, Air Source Air Conditioning, >=135 and <240 kBtu/h & 8.5 & 11 & 2008 & 5.4 & 24.6 & 31.0 & 463.1 \\
\hline Packaged Terminal Air Conditioning, 7-10 kBtu/h & 8.6 & 10.8 & 2008 & 0.4 & 1.8 & 2.2 & 33.3 \\
\hline Packaged Terminal Air Conditioning, 10-13 kBtu/h & 8.1 & 10.2 & 2008 & 0.6 & 2.6 & 3.3 & 49.5 \\
\hline
\end{tabular}




\section{Lighting and Appliance Standards}

Equipment, Materials, and Tools Decision Unit

Table 2. Key Assumptions and Results for Boilers and High-Capacity Instantaneous Water Heater

\begin{tabular}{|l|c|c|c|c|c|c|c|}
\hline \multicolumn{1}{|c|}{} & \multicolumn{2}{|c|}{ Efficiency (SEER and EER) } & \multicolumn{3}{c|}{$\begin{array}{c}\text { Energy Savings by Year } \\
\text { (TBtu) }\end{array}$} \\
\hline Equipment Category & EPAct 92 & New Std & Eff. Date & $\mathbf{2 0 1 0}$ & $\mathbf{2 0 2 0}$ & $\mathbf{2 0 3 0}$ & Cum. \\
\hline Pkg'd Boilers, Gas, 400 kBtu/h, Hot Water & $75 \%$ & $78 \%$ & 2008 & 0.2 & 0.9 & 1.7 & 19.7 \\
\hline Pkg'd Boilers, Gas, 800 kBtu/h, Hot Water & $75 \%$ & $78 \%$ & 2008 & 0.4 & 2.0 & 3.7 & 43.0 \\
\hline Pkg'd Boilers, Gas, 1500 kBtu/h, Hot Water & $75 \%$ & $78 \%$ & 2008 & 0.1 & 0.7 & 1.2 & 14.2 \\
\hline Pkg'd Boilers, Gas, 3000 kBtu/h, Hot Water & $75 \%$ & $80 \%$ & 2008 & 0.2 & 0.7 & 1.3 & 15.2 \\
\hline Pkg'd Boilers, Gas, 400 kBtu/h, Steam & $72 \%$ & $76 \%$ & 2008 & 0.1 & 0.6 & 1.1 & 12.6 \\
\hline Pkg'd Boilers, Gas, 800 kBtu/h, Steam & $72 \%$ & $76 \%$ & 2008 & 0.4 & 1.6 & 3.0 & 34.5 \\
\hline Pkg'd Boilers, Gas, 1500 kBtu/h, Steam & $72 \%$ & $79 \%$ & 2008 & 0.3 & 1.2 & 2.3 & 26.7 \\
\hline Pkg'd Boilers, Gas, 3000 kBtu/h, Steam & $72 \%$ & $80 \%$ & 2008 & 0.2 & 0.9 & 1.7 & 19.2 \\
\hline Instantaneous Water Heaters, 1000 kBtu/h & $80 \%$ & $83 \%$ & 2008 & 1.0 & 4.4 & 5.6 & 83.3 \\
\hline
\end{tabular}

- Introduction date of 2008

- Cost of $\$ 1400$.

\section{Non-Energy Benefits: (1)}

Reduced $\mathrm{CO}_{2}$ and $\mathrm{SO}_{x}$ emissions, reduced water consumption from plumbing equipment, increased life of equipment operating at cooler temperatures, and reduced first costs that transform new technologies into commodities.

\section{Program Strategy (\% of budget): (1)}

- Research and Development - 0\%

- Market Transformation - 0\%

- Codes and Standards - 100\%.

\section{Sources:}

(1) FY 2002 Budget Request - Data Bucket Report for the Lighting and Appliance Standards Program (internal BTS document).

(2) National Appliance Energy Conservation Act of 1987, Public Law 100-12.

(3) Energy Policy Act of 1992, Public Law 102-486.

(4) ASHRAE 90.1-1999, “Energy Standard for Buildings Except Low-Rise Residential Buildings."

(5) Geller, H. and S. Nadel. 1992. "Consensus National Efficiency Standards for Lamps, Motors, Showerheds and Faucets, and Commercial HVAC Equipment." In American Council for an Energy Efficient E conomy Proceeedings, p. 6.71-6.82. 


\section{Appendix A Baseline Assumptions}




\section{Appendix A \\ Baseline Scenario and Inputs for FY 2002 GPRA Metrics}

To obtain the GPRA metrics for FY 2002, the following baseline scenario and inputs were used. This information is common to all programs analyzed within BESET.

\section{Building Stock}

Building stock estimates are used to estimate the total energy savings at the national level for each program. Residential and commercial new and existing building stock totals for all years through 2020 were provided by EIS's Annual Energy Outlook 2000. The stock estimates have been developed for each market segment (e.g., building type, building vintage, and region) based on the following assumptions.

- Residential Single-Family and Multifamily Housing

- $60 \%$ of the existing building stock is in the north.

- $\quad 40 \%$ of the existing building stock is in the south.

- New stock is divided evenly across regions.

- Residential Manufactured Housing

- $\quad 48 \%$ of the existing building stock is in the north.

- $52 \%$ of the existing building stock is in the south.

- $\quad 45 \%$ of the new building stock is in the north.

- $55 \%$ of the new building stock is in the south.

- New stock is divided evenly across regions.

- Commercial Buildings

- $59 \%$ of the existing building stock is in the north.

- $\quad 41 \%$ of the existing building stock is in the south.

- $55 \%$ of the new building stock is in the north.

- $45 \%$ of the new building stock is in the south.

By using the assumptions listed above, the building stock numbers are segmented by building vintage and region. The base year is 2002, and all construction beginning with 2002 is considered "new."

The building stock was disaggregated into "north" and "south" regions by using the EIA climate zones published in the Residential Energy Consumption Survey and the Commercial Buildings Energy Consumption Survey. Climate zones 1 through 3 (i.e., zones with $>4,000$ heating-degree days) were designated as the "north" region, and zones 4 and 5 (i.e., zones with <4,000 heatingdegree days) were defined as the "south" regions (see Figure 1). Using this method, approximate percentages of north and south existing units and new construction were estimated.

\section{Existing Equipment Market Shares}

Equipment market shares were broken out by market segment and are estimated from Residential Energy Consumption Survey, the Commercial Buildings Energy Consumption Survey, and original PNNL efforts by Dave Belzer. 


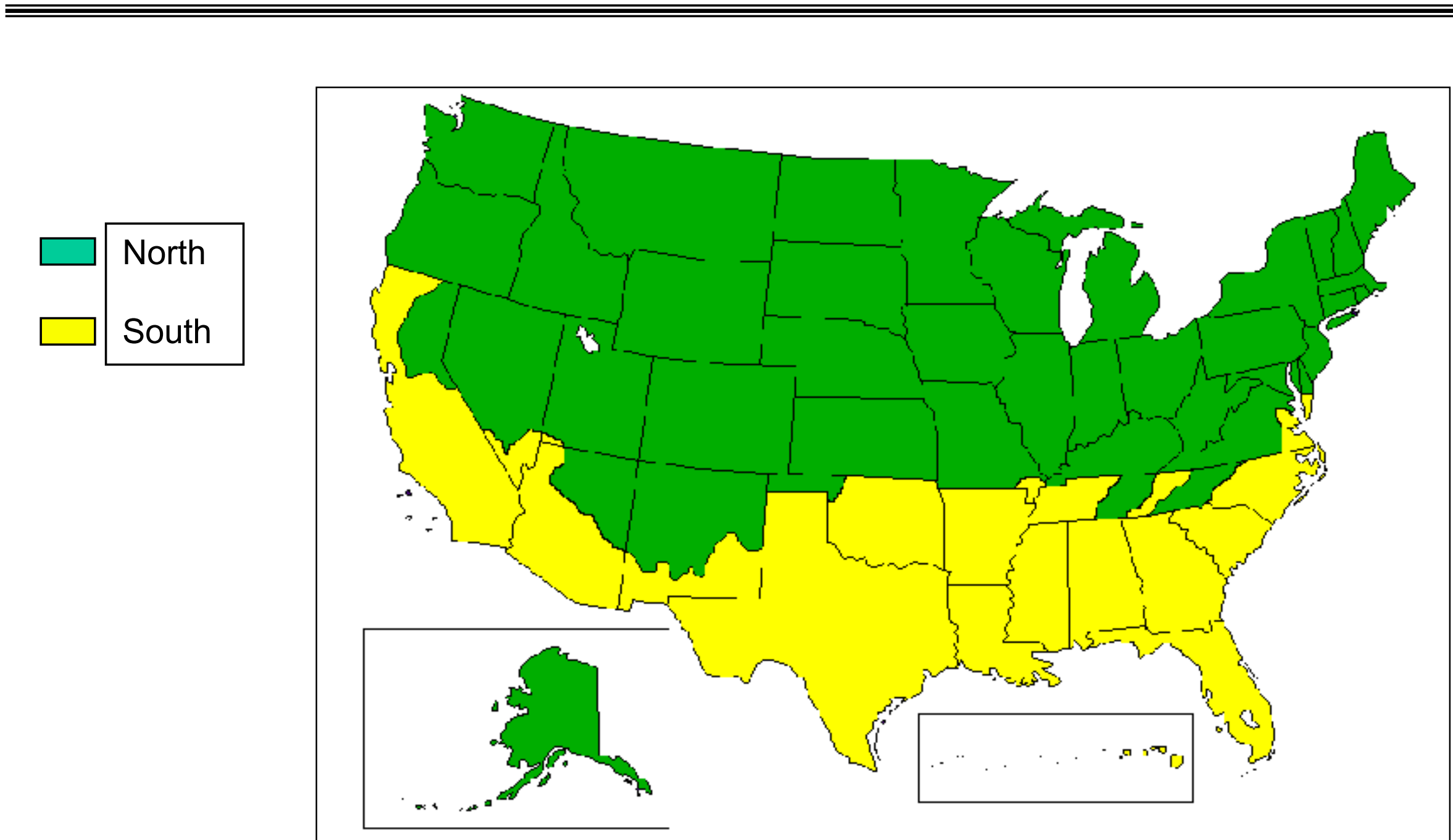

Figure 4. Regions for BTS GPRA Metrics 


\section{Existing Equipment Efficiencies}

The efficiency of equipment stock was developed from EIA's 1995 Annual Energy Outlook and input from Program Managers. Where applicable, the assumed stock efficiency increased to meet equipment standards.

\section{Equipment Life}

Equipment replacement factors are used in calculating the number of units representing the potential target market for programs targeting specific pieces of equipment. BTS technologies are assumed to compete only with "new" units. For new buildings, all units are considered new; therefore, the replacement factor for equipment in new buildings is 1.0.

For existing buildings, only units scheduled to be replaced are considered to be eligible for the BTS technology. In other words, the BTS technology is assumed not to replace a piece of equipment unless it was going to be replaced anyway. The replacement factor for existing buildings for a given year is based on the percentage of the equipment that is expected to turn over in that period (e.g., the factor for 2000 represents the percentage turnover from 1998 to 2000; the factor for 2005 represents the turnover percentage from 2001 to 2005, etc.). The replacement factors are based on the specific equipment's life expectancy. Baseline factors are taken from Appliance Magazine, NEMS, and the BTS Core Data Book.

\section{Sources}

Annual Energy Outlook, 1995, Energy Information Administration, Washington, D.C.

Annual Energy Outlook, 2000, Energy Information Administration, Washington, D.C.

BTS Core Databook, internal BTS document, U.S. Department of Energy.

Appliance Magazine. 1998. "Life Expectancy/Replacement Picture," 55(9):71. 


\section{Appendix B GPRA Data Cell}




\section{GPRA Data Call Fiscal Year 2002}

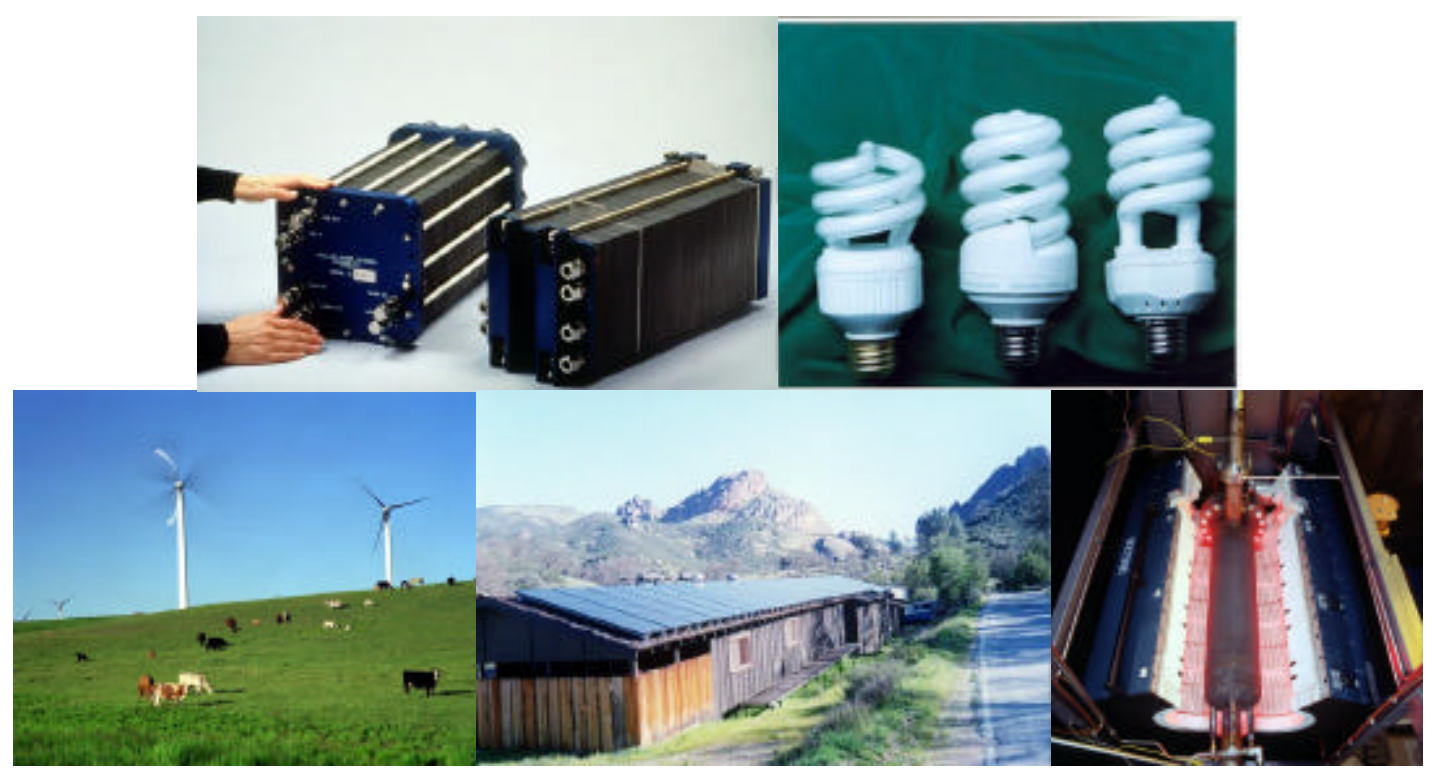

\section{July 13, 2000}

Form available on GPRAWeb at http://analysis.nrel.gov/gpraweb 


\section{APPENDIX B}

\section{Calculation Methodologies and AEO2000 Baseline Assumptions}

There are a variety of methods and assumptions that may be used to calculate the benefits of EERE programs. However, certain methodologies and assumptions may be applied to all of EERE's programs. This appendix provides methodologies and baseline assumptions for calculating energy, financial and environmental metrics requested in the GPRA2002 Data Call. Baseline assumptions are drawn from the Energy Information Administration's Annual Energy Outlook 2000 (AEO2000) and its supporting documentation. 


\section{Calculation Methodologies}

Converting from Direct to Primary Energy Displaced

The process for converting projections of direct energy displaced into a single total primary energy displaced metric involves four steps. These steps are displayed in the diagram below.

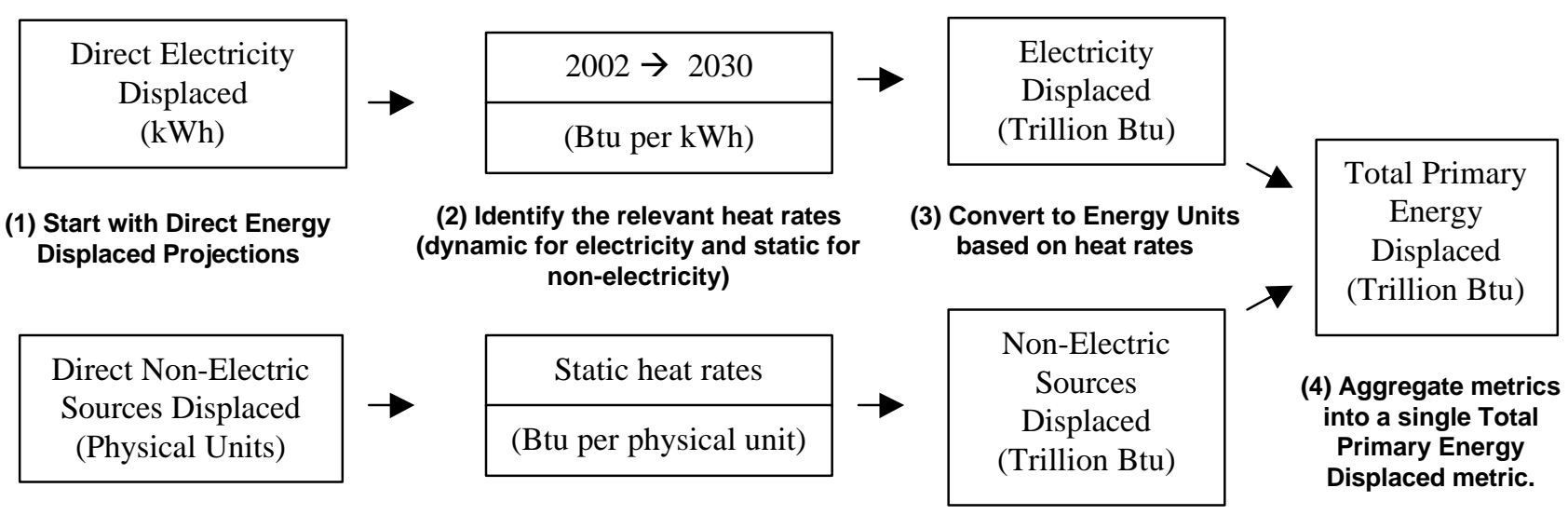

(1) The first step in the conversion process is to identify the electric and non-electric displaced energy projections. The direct electricity displaced projections will be expressed in kilowatthours; the direct non-electric projections will be expressed in barrels of oil, cubic feet of natural gas, and short tons of coal.

(2) The next step involves the conversion from direct units into heat content units using the heat rate of each direct fuel source.

\section{Electricity Heat Rates}

Electricity heat rates for GPRA2002 were derived by comparing the AEO2000 reference case against a side case in which electricity demand was reduced. The first step was to determine the marginal fuel mix based on the differences in $\mathrm{kWh}$ of electricity generated. The results, shown in the table below, indicate that EERE technologies are projected to displace electricity generated from fossil fuels. 


\section{Projected Marginal Fuel Generation Mix}

(based on marginal $\mathrm{kWh}$ generated)

\begin{tabular}{|l|r|r|r|r|r|r|r|r|r|r|}
\hline Fuel Mix & 2002 & 2003 & 2004 & 2005 & 2006 & 2010 & 2015 & 2020 & 2025 & 2030 \\
\hline Coal & $33.9 \%$ & $30.2 \%$ & $27.8 \%$ & $21.5 \%$ & $25.1 \%$ & $16.7 \%$ & $17.1 \%$ & $26.3 \%$ & $32.9 \%$ & $32.9 \%$ \\
\hline Natural Gas & $48.1 \%$ & $52.0 \%$ & $55.1 \%$ & $56.4 \%$ & $56.9 \%$ & $75.7 \%$ & $71.8 \%$ & $65.5 \%$ & $60.1 \%$ & $60.1 \%$ \\
\hline Oil & $18.0 \%$ & $17.8 \%$ & $17.0 \%$ & $22.0 \%$ & $18.0 \%$ & $7.6 \%$ & $11.1 \%$ & $8.2 \%$ & $7.0 \%$ & $7.0 \%$ \\
\hline
\end{tabular}

The second step was to calculate the marginal electricity heat rates for each fuel source based on a comparison of the two cases. The results are shown in the table below.

\section{Projected Marginal Electricity Heat Rates by Fuel Source}

\begin{tabular}{|l|r|r|r|r|r|r|r|r|r|r|}
\hline $\begin{array}{l}\text { Projected Electricity Heat } \\
\text { Rates }\end{array}$ & 2002 & 2003 & 2004 & 2005 & 2006 & 2010 & 2015 & 2020 & 2025 & 2030 \\
\hline Coal (Btu per kWh) & 11489 & 11108 & 11271 & 11530 & 11287 & 10212 & 10388 & 8801 & 8801 & 8801 \\
\hline Natural Gas (Btu per kWh) & 10989 & 10967 & 10182 & 9557 & 9432 & 7724 & 7413 & 7031 & 7031 & 7031 \\
\hline Oil (Btu per kWh) & 10363 & 10510 & 10702 & 10732 & 10408 & 10501 & 10590 & 10298 & 10298 & 10298 \\
\hline
\end{tabular}

To derive the dynamic GPRA2002 electricity heat rates, the percentage of the marginal mix associated with each fuel source was multiplied by the expected electricity heat rate for the same source. This yielded the intermediate apportioned heat content associated with each generation source. Then, for each forecast year, the apportioned heat contents were summed to arrive at a final GPRA2002 heat rate. For example, in the year 2020, electricity generated from coal is expected to account for 26.3 percent of the marginal mix, electricity generated from natural gas 65.5 percent, and oil 8.2 percent. The expected electricity heat rates in 2020 for coal, natural gas and oil are 8,801 and 7,031 and 10,298 Btu/kWh, respectively. Therefore, the GPRA2002 heat rate for 2020 is $(26.3 \%)(8,801)+(65.5 \%)(7,031)+(8.2 \%)(10,298)=7,765 \mathrm{Btu} / \mathrm{kWh}$.

\section{GPRA2002 Electricity Heat Rates}

\begin{tabular}{|l|r|r|r|r|r|r|r|r|r|r|}
\hline GPRA2002 Heat Rate & 2002 & 2003 & 2004 & 2005 & 2006 & 2010 & 2015 & 2020 & 2025 & 2030 \\
\hline Electricity (Btu per kWh) & 11045 & 10928 & 10574 & 10241 & 10074 & 8350 & 8276 & 7765 & 7839 & 7839 \\
\hline
\end{tabular}




\section{Non-Electric Heat Rates}

The heat rates used for conversion of non-electric sources are much more straightforward. The table below contains the appropriate conversion factors for these sources that are based on heat rate estimates provided in AEO2000 Table H1. Simply find the matching direct energy displaced source with the appropriate heat rate from the table below.

\section{GPRA2002 Non-Electricity Heat Rates}

\begin{tabular}{|l|l|l|r|}
\hline Coal & Coal Production & million Btu per short ton & 21.296 \\
\cline { 2 - 4 } & Coal Consumption & million Btu per short ton & 20.835 \\
\cline { 2 - 4 } & Coke Plants & million Btu per short ton & 26.800 \\
\cline { 2 - 4 } & Industrial & million Btu per short ton & 22.172 \\
\cline { 2 - 4 } & Residential and Commercial & million Btu per short ton & 22.494 \\
\cline { 2 - 4 } & Electric Utilities & million Btu per short ton & 20.548 \\
\hline \multirow{6}{*}{ Oil } & Crude Oil Production & million Btu per barrel & 5.800 \\
\hline \multirow{6}{*}{} & Oil Products Consumption & million Btu per barrel & 5.358 \\
\cline { 2 - 4 } & Motor Gasoline & million Btu per barrel & 5.213 \\
\cline { 2 - 4 } & Jet Fuel (Kerosene) & million Btu per barrel & 5.670 \\
\cline { 2 - 4 } & Distillate Fuel Oil & million Btu per barrel & 5.825 \\
\cline { 2 - 4 } & Residual Fuel Oil & million Btu per barrel & 6.287 \\
\cline { 2 - 4 } & Liquefied Petroleum Gas & million Btu per barrel & 3.625 \\
\cline { 2 - 4 } & Kerosene & million Btu per barrel & 5.670 \\
\cline { 2 - 4 } & Petrochemical Feedstocks & million Btu per barrel & 5.630 \\
\cline { 2 - 4 } & Unfinished Oils & million Btu per barrel & 5.800 \\
\hline Natural & Gas & \multicolumn{3}{|c}{} \\
\hline \multirow{3}{*}{} & Natural Gas Production & Btu per cubic foot & 1,028 \\
\cline { 2 - 4 } & Natural Gas Consumption & Btu per cubic foot & 1,028 \\
\cline { 2 - 4 } & Non-electric Utilities & Btu per cubic foot & 1,029 \\
\cline { 2 - 4 } & Electric Utilities & Btu per cubic foot & 1,022 \\
\hline
\end{tabular}

Source: AEO2000, Table H1.

(3) The third step involves multiplying the above heat rates by the direct energy displaced projections.

(4) The final step is to sum the energy displaced estimates (not expressed in heat content units) for each forecast year. 


\section{Converting from Direct to Primary Energy - An Example}

To better understand the mechanics of the energy conversion process, consider the following example. The direct energy displaced projections for a hypothetical Planning Unit EE are displayed in the table below. Assume Planning Unit EE is a demand-side technological development program which displaces electricity and natural gas in the commercial buildings sector.

Step 1 consists of simply identifying the direct energy displaced estimates for each forecast year.

\begin{tabular}{|l|r|r|r|r|r|r|r|r|r|r|}
\cline { 2 - 9 } Step (1) & 2002 & 2003 & 2004 & 2005 & 2006 & 2010 & 2015 & 2020 & 2025 & 2030 \\
\hline $\begin{array}{l}\text { Direct Electricity Displaced } \\
\text { (billion kWhs) }\end{array}$ & 0.00 & 0.50 & 1.20 & 2.10 & 3.20 & 11.00 & 25.00 & 41.00 & 61.00 & 90.00 \\
\hline $\begin{array}{l}\text { Direct Natural Gas Displaced } \\
\text { (billion cubic feet) }\end{array}$ & 1.00 & 2.00 & 3.50 & 5.50 & 8.20 & 31.00 & 66.00 & 102.00 & 150.00 & 200.00 \\
\hline
\end{tabular}

In step 2, the relevant heat rates are identified. A static conversion factor is used for the nonelectric projections while a dynamic heat rate is used for electricity.

\begin{tabular}{|l|r|r|r|r|r|r|r|r|r|r|}
\cline { 2 - 9 } Step (2) & 2002 & 2003 & 2004 & 2005 & 2006 & 2010 & 2015 & 2020 & 2025 & 2030 \\
\hline $\begin{array}{l}\text { Electricity } \\
\text { (Btu per kWh) }\end{array}$ & 11045 & 10928 & 10574 & 10241 & 10074 & 8350 & 8276 & 7765 & 7839 & 7839 \\
\hline $\begin{array}{l}\text { Natural Gas Consumption } \\
\text { (Btu per cubic foot) }\end{array}$ & 1028 & 1028 & 1028 & 1028 & 1028 & 1028 & 1028 & 1028 & 1028 & 1028 \\
\hline
\end{tabular}

In step 3, all direct energy displaced estimates are converted from physical units to heat content units by multiplying by the appropriate heat rates.

\begin{tabular}{|l|r|r|r|r|r|r|r|r|r|r|}
\cline { 2 - 10 } Step (3) & 2002 & 2003 & 2004 & 2005 & 2006 & 2010 & 2015 & 2020 & 2025 & 2030 \\
\hline Electricity (trillion Btu) & 0.00 & 5.46 & 12.69 & 21.51 & 32.24 & 91.85 & 206.89 & 318.37 & 478.18 & 705.52 \\
\hline Natural Gas (trillion Btu) & 1.03 & 2.06 & 3.60 & 5.65 & 8.43 & 31.87 & 67.85 & 104.86 & 154.20 & 205.60 \\
\hline
\end{tabular}

After all of the metrics have been converted to heat content units, the last step involves summing the metrics in each forecast year.

\begin{tabular}{|l|r|r|r|r|r|r|r|r|r|r|}
\cline { 2 - 10 } Step (4) & 2002 & 2003 & 2004 & 2005 & 2006 & 2010 & 2015 & 2020 & 2025 & 2030 \\
\hline $\begin{array}{l}\text { Total Primary Energy } \\
\text { Displaced (trillion Btu) }\end{array}$ & 1.03 & 7.52 & 16.29 & 27.16 & 40.66 & 123.72 & 274.74 & 423.23 & 632.38 & 911.12 \\
\hline
\end{tabular}




\section{Calculating Energy Cost Savings}

The methodology for calculating energy cost savings differs slightly for electricity and nonelectricity energy sources. For non-electricity energy sources, sector energy prices are applied to the projections of primary energy displaced by energy source to obtain energy cost savings by energy source. For electricity, the amount of direct electricity displaced in $\mathrm{kWh}$ is converted to site electricity in trillion btu and then multiplied by the sector electricity price. Electricity and non-electricity cost savings estimates are then summed to arrive at total energy cost savings. The GPRA2002 Data Call uses energy prices in Table 20 of the Assumptions to the AEO2000 (found later in Appendix B).

\section{Calculating Energy Cost Savings - An Example}

To better understand how to calculate energy cost savings, consider the following example. The process starts with the estimates of direct energy displaced.

\begin{tabular}{|l|r|r|r|r|r|r|r|r|r|r|}
\cline { 2 - 9 } Step (1) & 2002 & 2003 & 2004 & 2005 & 2006 & 2010 & 2015 & 2020 & 2025 & 2030 \\
\hline $\begin{array}{l}\text { Direct Electricity Displaced } \\
\text { (billion kWhs) }\end{array}$ & 0.00 & 0.50 & 1.20 & 2.10 & 3.20 & 11.00 & 25.00 & 41.00 & 61.00 & 90.00 \\
\hline $\begin{array}{l}\text { Direct Natural Gas Displaced } \\
\text { (billion cubic feet) }\end{array}$ & 1.00 & 2.00 & 3.50 & 5.50 & 8.20 & 31.00 & 66.00 & 102.00 & 150.00 & 200.00 \\
\hline
\end{tabular}

Heat rates are applied to the estimates. Note that an electricity consumption heat rate is used.

\begin{tabular}{|c|c|c|c|c|c|c|c|c|c|c|}
\hline Step (2) & 2002 & 2003 & 2004 & 2005 & 2006 & 2010 & 2015 & 2020 & 2025 & 2030 \\
\hline $\begin{array}{l}\text { Electricity Consumption } \\
\text { (Btu per kWh) }\end{array}$ & 3412 & 3412 & 3412 & 3412 & 3412 & 3412 & 3412 & 3412 & 3412 & 3412 \\
\hline $\begin{array}{l}\text { Natural Gas Consumption } \\
\text { (Btu per cubic foot) }\end{array}$ & 1028 & 1028 & 1028 & 1028 & 1028 & 1028 & 1028 & 1028 & 1028 & 8 \\
\hline
\end{tabular}

This results in the heat content for each energy source.

\begin{tabular}{|l|r|r|r|r|r|r|r|r|r|r|}
\cline { 2 - 10 } Step (3) & 2002 & 2003 & 2004 & 2005 & 2006 & 2010 & 2015 & 2020 & 2025 & 2030 \\
\hline Site Electricity (trillion Btu) & 0.00 & 1.71 & 4.09 & 7.17 & 10.92 & 37.53 & 85.30 & 139.89 & 208.13 & 307.08 \\
\hline Natural Gas (trillion Btu) & 1.03 & 2.06 & 3.60 & 5.65 & 8.43 & 31.87 & 67.85 & 104.86 & 154.20 & 205.60 \\
\hline
\end{tabular}

Appropriate energy prices are applied (commercial buildings sector prices are used here).

\begin{tabular}{|l|r|r|r|r|r|r|r|r|r|r|}
\cline { 2 - 9 } Step (4) & 2002 & 2003 & 2004 & 2005 & 2006 & 2010 & 2015 & 2020 & 2025 & 2030 \\
\hline Electricity (\$ per million Btu) & 20.13 & 19.91 & 19.69 & 19.31 & 19.26 & 18.65 & 18.37 & 18.17 & 17.44 & 16.73 \\
\hline $\begin{array}{l}\text { Natural Gas (\$ per million } \\
\text { Btu) }\end{array}$ & 5.42 & 5.43 & 5.45 & 5.48 & 5.52 & 5.53 & 5.48 & 5.50 & 5.55 & 5.60 \\
\hline
\end{tabular}


Resulting in energy cost savings projections for each fuel.

\begin{tabular}{|c|c|c|c|c|c|c|c|c|c|c|}
\hline Step (5) & 2002 & 2003 & 2004 & 2005 & 2006 & 2010 & 2015 & 2020 & 2025 & 2030 \\
\hline Electricity ( $\$$ billions) & 0.00 & 0.03 & 0.08 & 0.14 & 0.21 & 0.70 & 1.57 & 2.54 & 3.63 & 5.14 \\
\hline Natural Gas (\$ billions) & 0.01 & 0.01 & 0.02 & 0.03 & 0.05 & 0.18 & 0.37 & 0.58 & 0.86 & 1.15 \\
\hline
\end{tabular}

Individual fuel savings estimates are summed to arrive at a final metric of energy cost savings (components may not sum to totals due to rounding).

\begin{tabular}{|l|r|r|r|r|r|r|r|r|r|r|}
\cline { 2 - 9 } Step (6) & 2002 & 2003 & 2004 & 2005 & 2006 & 2010 & 2015 & 2020 & 2025 & 2030 \\
\hline $\begin{array}{l}\text { Total Energy Cost Savings } \\
\text { (\$ billions) }\end{array}$ & 0.01 & 0.05 & 0.10 & 0.17 & 0.26 & 0.88 & 1.94 & 3.12 & 4.48 & 6.29 \\
\hline
\end{tabular}




\section{Calculating Carbon Equivalent Emissions Displaced}

The methodology for calculating the level of carbon equivalent emissions displaced continues from the conversion of direct to primary energy displaced. Emission factors for carbon are applied to the projections of primary energy displaced by energy source to obtain carbon equivalent emissions displaced by energy source. These estimates are then summed to arrive at a final metric of carbon equivalent emissions displaced.

The GPRA2002 Data Call uses carbon emission factors found in Table 2 of the Assumptions to the AEO2000. These emission factors are based on the carbon content of the fuel and the fraction of the fuel consumed in combustion. The emission factors are based on 1998 data.

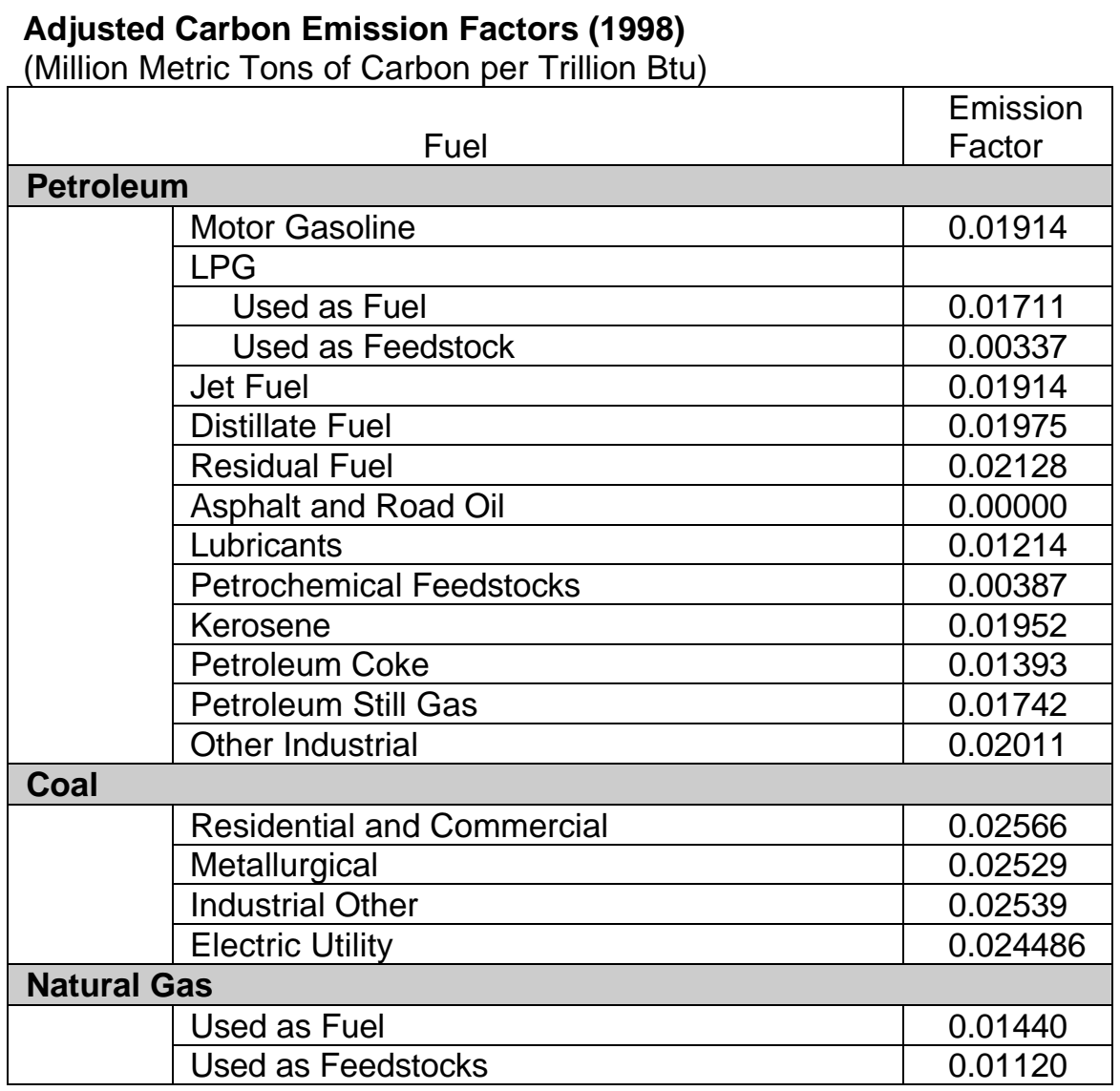

Like the electricity heat rate, the carbon emission factor for electricity changes over the forecast period with the changing projections of the marginal fuel mix. The petroleum mix for the utility sector is $95 \%$ residual fuel and $5 \%$ distillate fuel.

Electricity Carbon Emission Factor (million metric tons of carbon per trillion Btu)

\begin{tabular}{|l|r|r|r|r|r|r|r|r|r|r|}
\hline Carbon Coefficient & 2002 & 2003 & 2004 & 2005 & 2006 & 2010 & 2015 & 2020 & 2025 & 2030 \\
\hline Electricity (MMTCE per trillion Btu) & 0.01910 & 0.01866 & 0.01856 & 0.01842 & 0.01850 & 0.01711 & 0.01754 & 0.01815 & 0.01875 & 0.01875 \\
\hline
\end{tabular}




\section{Calculating Carbon Equivalent Emissions Displaced - An Example}

To better understand how to calculate displacement of carbon equivalent emissions, consider the following example, which continues from Step 3 of the direct-to-primary energy example.

\begin{tabular}{|l|r|r|r|r|r|r|r|r|r|r|}
\cline { 2 - 10 } Step (3) & 2002 & 2003 & 2004 & 2005 & 2006 & 2010 & 2015 & 2020 & 2025 & 2030 \\
\hline Electricity (trillion Btu) & 0.00 & 5.46 & 12.69 & 21.51 & 32.24 & 91.85 & 206.89 & 318.37 & 478.18 & 705.52 \\
\hline Natural Gas (trillion Btu) & 1.03 & 2.06 & 3.60 & 5.65 & 8.43 & 31.87 & 67.85 & 104.86 & 154.20 & 205.60 \\
\hline
\end{tabular}

Instead of summing these metrics to arrive at a final total primary energy displaced metric, the appropriate carbon emissions coefficients are applied.

\begin{tabular}{|l|r|r|r|r|r|r|r|r|r|r|}
\cline { 2 - 9 } Step (4) & 2002 & 2003 & 2004 & 2005 & 2006 & 2010 & 2015 & 2020 & 2025 & 2030 \\
\hline $\begin{array}{l}\text { Electricity } \\
\text { (MMTCE per trillion Btu) }\end{array}$ & 0.01910 & 0.01866 & 0.01856 & 0.01842 & 0.01850 & 0.01711 & 0.01754 & 0.01815 & 0.01875 & 0.01875 \\
\hline $\begin{array}{l}\text { Natural Gas } \\
\text { (MMTCE per trillion Btu) }\end{array}$ & 0.01440 & 0.01440 & 0.01440 & 0.01440 & 0.01440 & 0.01440 & 0.01440 & 0.01440 & 0.01440 & 0.01440 \\
\hline
\end{tabular}

The resultant emissions displaced projections are listed in the table below.

\begin{tabular}{|l|r|r|r|r|r|r|r|r|r|r|}
\cline { 2 - 10 } \multicolumn{1}{c|}{ Step (5) } & 2002 & 2003 & 2004 & 2005 & 2006 & 2010 & 2015 & 2020 & 2025 & 2030 \\
\hline Electricity (MMTCE) & 0.00 & 0.10 & 0.24 & 0.40 & 0.60 & 1.57 & 3.63 & 5.78 & 8.97 & 13.23 \\
\hline Natural Gas (MMTCE) & 0.01 & 0.03 & 0.05 & 0.08 & 0.12 & 0.46 & 0.98 & 1.51 & 2.22 & 2.96 \\
\hline
\end{tabular}

The final step is to sum these individual estimates to arrive at a final metric of carbon equivalent emissions displaced as illustrated below (components may not sum to totals due to rounding).

\begin{tabular}{|l|r|r|r|r|r|r|r|r|r|r|}
\cline { 2 - 9 } Step (6) & 2002 & 2003 & 2004 & 2005 & 2006 & 2010 & 2015 & 2020 & 2025 & 2030 \\
\hline $\begin{array}{l}\text { Carbon Equivalent Emissions } \\
\text { Displaced (MMTons) }\end{array}$ & 0.01 & 0.13 & 0.29 & 0.48 & 0.72 & 2.03 & 4.61 & 7.29 & 11.19 & 16.19 \\
\hline
\end{tabular}




\section{Calculating Criteria Pollutants Displaced}

Calculating the amount of criteria pollutants displaced is similar to calculating the displacement of carbon equivalent emissions. Emission factors are applied to primary energy displaced by energy source to obtain criteria pollutant displacement levels by energy source. These estimates as then summed to obtain total criteria pollutant displaced levels.

The Environmental Protection Agency catalogues emission factors for numerous technologies. For the GPRA Data Call more generic emission factors have been calculated from aggregate emission and energy consumption data provided by EPA for 1997. These are provided in the tables below. Emission factors for specific technologies may be obtained from EPA's Compilation of Air Pollutant Emission Factors (AP-42) available on the world wide web at http://www.epa.gov/ttn/chief/ap42etc.html

Emission Factors of Criteria Pollutants

(MMTons of emissions per trillion Btu)

\begin{tabular}{|l|c|c|c|c|c|}
\hline Fuel & NOx & SO2 & VOCs & CO & PM10 \\
\hline Coal & 0.000254 & 0.000568 & 0.000001 & 0.000011 & 0.000012 \\
\hline Natural Gas & 0.000106 & 0.000000 & 0.000003 & 0.000029 & 0.000000 \\
\hline Oil & 0.000140 & 0.000527 & 0.000004 & 0.000013 & 0.000007 \\
\hline
\end{tabular}

Like the electricity carbon emission factor, the electricity criteria pollutant emission factors are dynamic, changing over time with the changing fuel mix.

Electricity Emission Factors of Criteria Pollutants

(MMTons of emissions per trillion Btu)

\begin{tabular}{|l|r|r|r|r|r|r|r|r|r|r|}
\hline Criteria Coefficients & 2002 & 2003 & 2004 & 2005 & 2006 & 2010 & 2015 & 2020 & 2025 & 2030 \\
\hline NOx (MMTons per trillion Btu) & 0.000164 & 0.000157 & 0.000156 & 0.000150 & 0.000154 & 0.000140 & 0.000143 & 0.000154 & 0.000164 & 0.000164 \\
\hline SO2 (MMTons per trillion Btu) & 0.000289 & 0.000265 & 0.000260 & 0.000260 & 0.000258 & 0.000166 & 0.000197 & 0.000227 & 0.000258 & 0.000258 \\
\hline VOCs (MMTons per trillion Btu) & 0.000003 & 0.000003 & 0.000003 & 0.000003 & 0.000003 & 0.000003 & 0.000003 & 0.000003 & 0.000002 & 0.000002 \\
\hline CO (MMTons per trillion Btu) & 0.000020 & 0.000021 & 0.000021 & 0.000021 & 0.000021 & 0.000024 & 0.000023 & 0.000022 & 0.000021 & 0.000021 \\
\hline PM10 (MMTons per trillion Btu) & 0.000005 & 0.000005 & 0.000005 & 0.000005 & 0.000005 & 0.000003 & 0.000004 & 0.000004 & 0.000005 & 0.000005 \\
\hline
\end{tabular}




\section{Calculating Criteria Pollutant Emissions Displaced - An Example}

To better understand the calculations behind criteria pollutants displaced, consider the following example for calculating emissions of NOx displaced. Similar steps would be taken for calculating SO2, VOCs, CO and PM10. Steps 1-3 of the energy conversion process for Planning Unit EE yielded the following energy displacement estimates by fuel source.

\begin{tabular}{|l|r|r|r|r|r|r|r|r|r|r|}
\cline { 2 - 10 } Step (3) & 2002 & 2003 & 2004 & 2005 & 2006 & 2010 & 2015 & 2020 & 2025 & 2030 \\
\hline Electricity (trillion Btu) & 0.00 & 5.46 & 12.69 & 21.51 & 32.24 & 91.85 & 206.89 & 318.37 & 478.18 & 705.52 \\
\hline Natural Gas (trillion Btu) & 1.03 & 2.06 & 3.60 & 5.65 & 8.43 & 31.87 & 67.85 & 104.86 & 154.20 & 205.60 \\
\hline
\end{tabular}

Instead of summing these metrics to arrive at a total primary energy displaced metric, the appropriate emission factors are applied.

\begin{tabular}{|l|r|r|r|r|r|r|r|r|r|r|}
\cline { 2 - 9 } Step (4) & 2002 & 2003 & 2004 & 2005 & 2006 & 2010 & 2015 & 2020 & 2025 & 2030 \\
\hline $\begin{array}{l}\text { Electricity (MMTon } \\
\text { of NOx per trillion } \\
\text { Btu) }\end{array}$ & 0.000164 & 0.000157 & 0.000156 & 0.000150 & 0.000154 & 0.000140 & 0.000143 & 0.000154 & 0.000164 & 0.000164 \\
\hline $\begin{array}{l}\text { Natural Gas } \\
\text { (MMTons of NOx } \\
\text { per trillion Btu) }\end{array}$ & 0.000106 & 0.000106 & 0.000106 & 0.000106 & 0.000106 & 0.000106 & 0.000106 & 0.000106 & 0.000106 & 0.000106 \\
\hline
\end{tabular}

The resultant emissions displaced for NOx are listed in the table below. Similar calculations would be performed for SO2, VOCs, CO and PM10.

\begin{tabular}{|l|r|r|r|r|r|r|r|r|r|r|}
\cline { 2 - 10 } Step (5) & 2002 & 2003 & 2004 & 2005 & 2006 & 2010 & 2015 & 2020 & 2025 & 2030 \\
\hline Electricity (MMTons NOx) & 0.000 & 0.001 & 0.002 & 0.003 & 0.005 & 0.013 & 0.030 & 0.049 & 0.078 & 0.116 \\
\hline Natural Gas (MMTons NOx) & 0.000 & 0.000 & 0.000 & 0.001 & 0.001 & 0.003 & 0.007 & 0.011 & 0.016 & 0.022 \\
\hline
\end{tabular}

The final step is to sum these individual estimates to arrive at a final metric of NOx emissions displaced as illustrated below.

\begin{tabular}{|l|r|r|r|r|r|r|r|r|r|r|}
\cline { 2 - 9 } Step (6) & 2002 & 2003 & 2004 & 2005 & 2006 & 2010 & 2015 & 2020 & 2025 & 2030 \\
\hline NOx Displaced (MMTons) & 0.000 & 0.001 & 0.002 & 0.004 & 0.006 & 0.016 & 0.037 & 0.060 & 0.095 & 0.138 \\
\hline
\end{tabular}




\section{Energy Information Administration Annual Energy Outlook 2000 Baseline Assumption Tables*}

\section{CROSSCUTTING}

Table 20. Energy Prices by Sector and Source for the United States

\section{BUILDINGS}

Table 21. Residential Sector Supplement Table

Table 22. Commercial Sector Supplement Table

\section{INDUSTRY}

Table 23. Industrial Sector Macroeconomic Indicators

Table 24. Refining Industry Energy Consumption

Table 25. Food Industry Energy Consumption

Table 26. Paper Industry Energy Consumption

Table 27. Bulk Chemical Industry Energy Consumption

Table 28. Glass Industry Energy Consumption

Table 29. Cement Industry Energy Consumption

Table 30. Iron and Steel Industries Energy Consumption

Table 31. Aluminum Industry Energy Consumption

Table 32. Other Industrial Sector Energy Consumption

\section{TRANSPORTATION}

Table 33. Transportation Sector Energy Use by Mode and Type (Trillion Btu)

Table 34. Transportation Sector Energy Use by Fuel Type Within a Mode

Table 35. Light-Duty Vehicle Energy Consumption by Technology Type and Fuel Type (Trillion Btu)

Table 45. Light-Duty Vehicle Sales by Technology Type (Thousands)

Table 46. Light-Duty Vehicle Stock by Technology Type (Millions)

Table 47. Light-Duty Vehicle MPG by Technology Type (MPG Gasoline Equivalents)

Table 49. Light-Duty Vehicle VMT by Technology Type

Table 50. Summary of New Light-Duty Vehicle Size Class Attributes

Table 51. Transportation Fleet Car and Truck Fuel Consumption by Type and Technology

Table 52. Transportation Fleet Car and Truck Sales by Type and Technology (Thousands)

Table 53. Transportation Fleet Car and Truck Stock by Type and Technology (Thousands)

Table 54. Transportation Fleet Car and Truck VMT by Type and Technology

Table 57. New Light-Duty Vehicle Fuel Economy

Table 58. New Light-Duty Vehicle Prices

Table 59. New Light-Duty Vehicle Range

\section{ELECTRICITY \& RENEWABLES}

Table 73. Electric Power Projections for EMM Region

Table 76. Renewable Resources Consumption/Displacement by Source for Electricity

Table 17. Renewable Energy Generating Capability and Generation ${ }^{\star *}$

* Tables in the AEO2000 contain projections to 2020. These projections have been extended to 2030 using the average growth rate from 1998-2020.

** Table 17 is from AEO2000 Model Output

Please contact John Mortensen at NREL (john_mortensen@nrel.gov) if you would like copies of the above tables in spreadsheet format. All AEO99 supplemental tables may be found on the EIA website at http://www.eia.doe.gov/oiaf/aeo/supplement/index.html 
Table 20. Energy Prices by Sector and Source

(1998 Dollars per Million Btu, Unless Otherwise Noted)

United States Average

\begin{tabular}{|c|c|c|c|c|c|c|c|c|c|c|}
\hline & 2002 & 2003 & 2004 & 2005 & 2006 & 2010 & 2015 & 2020 & 2025 & 2030 \\
\hline Residential & 13.07 & 13.07 & 13.08 & 13.03 & 13.08 & 13.09 & 13.08 & 13.10 & 13.05 & 13.01 \\
\hline Primary Energy 1/ & 7.13 & 7.12 & 7.13 & 7.15 & 7.16 & 7.11 & 6.99 & 6.92 & 6.96 & 7.00 \\
\hline Petroleum Products $2 /$ & 9.35 & 9.41 & 9.46 & 9.48 & 9.54 & 9.73 & 9.88 & 10.04 & 10.73 & 11.47 \\
\hline Distillate Fuel & 7.45 & 7.51 & 7.53 & 7.55 & 7.59 & 7.74 & 7.82 & 7.88 & 8.35 & 8.84 \\
\hline Liquefied Petroleum Gas & 13.02 & 13.02 & 13.10 & 13.06 & 13.09 & 13.21 & 13.37 & 13.62 & 14.48 & 15.39 \\
\hline Natural Gas & 6.60 & 6.59 & 6.60 & 6.62 & 6.64 & 6.57 & 6.43 & 6.36 & 6.31 & 6.26 \\
\hline Electricity & 22.35 & 22.25 & 22.17 & 21.90 & 21.92 & 21.67 & 21.50 & 21.33 & 20.85 & 20.38 \\
\hline Commercial & 12.60 & 12.53 & 12.46 & 12.32 & 12.34 & 12.14 & 12.04 & 12.00 & 11.75 & 11.52 \\
\hline Primary Energy $1 /$ & 5.42 & 5.43 & 5.46 & 5.49 & 5.52 & 5.54 & 5.51 & 5.53 & 5.64 & 5.76 \\
\hline Petroleum Products 2/ & 6.04 & 6.08 & 6.11 & 6.12 & 6.15 & 6.27 & 6.36 & 6.49 & 7.04 & 7.63 \\
\hline Distillate Fuel & 5.29 & 5.35 & 5.36 & 5.38 & 5.42 & 5.56 & 5.63 & 5.73 & 6.24 & 6.81 \\
\hline Residual Fuel & 3.66 & 3.67 & 3.69 & 3.70 & 3.71 & 3.74 & 3.79 & 3.87 & 4.28 & 4.73 \\
\hline Natural Gas 3/ & 5.42 & 5.43 & 5.45 & 5.48 & 5.52 & 5.53 & 5.48 & 5.50 & 5.55 & 5.60 \\
\hline Electricity & 20.13 & 19.91 & 19.69 & 19.31 & 19.26 & 18.65 & 18.37 & 18.17 & 17.44 & 16.73 \\
\hline Industrial 4/ & 5.39 & 5.38 & 5.39 & 5.38 & 5.41 & 5.48 & 5.55 & 5.65 & 5.84 & 6.04 \\
\hline Primary Energy & 4.11 & 4.13 & 4.16 & 4.18 & 4.21 & 4.32 & 4.42 & 4.55 & 4.85 & 5.18 \\
\hline Petroleum Products 2/ & 5.78 & 5.79 & 5.81 & 5.79 & 5.80 & 5.88 & 5.97 & 6.11 & 6.52 & 6.96 \\
\hline Distillate Fuel & 5.39 & 5.45 & 5.47 & 5.49 & 5.53 & 5.66 & 5.71 & 5.89 & 6.42 & 7.00 \\
\hline Liquefied Petroleum Gas & 7.82 & 7.79 & 7.85 & 7.79 & 7.80 & 7.87 & 8.00 & 8.25 & 8.54 & 8.83 \\
\hline Residual Fuel & 3.14 & 3.15 & 3.16 & 3.17 & 3.19 & 3.23 & 3.30 & 3.38 & 3.62 & 3.88 \\
\hline Natural Gas 5/ & 2.91 & 2.95 & 3.00 & 3.08 & 3.15 & 3.28 & 3.38 & 3.50 & 3.73 & 3.97 \\
\hline Metallurgical Coal & 1.71 & 1.69 & 1.68 & 1.66 & 1.65 & 1.60 & 1.56 & 1.50 & 1.45 & 1.41 \\
\hline Steam Coal & 1.36 & 1.35 & 1.34 & 1.32 & 1.31 & 1.26 & 1.21 & 1.16 & 1.11 & 1.05 \\
\hline Electricity & 12.46 & 12.29 & 12.14 & 11.92 & 11.92 & 11.66 & 11.43 & 11.27 & 10.89 & 10.53 \\
\hline Transportation & 8.97 & 9.00 & 9.03 & 9.08 & 9.06 & 9.13 & 9.11 & 9.04 & 9.42 & 9.82 \\
\hline Primary Energy & 8.95 & 8.98 & 9.01 & 9.06 & 9.04 & 9.11 & 9.09 & 9.02 & 9.40 & 9.80 \\
\hline Petroleum Products 2/ & 8.95 & 8.98 & 9.02 & 9.06 & 9.04 & 9.11 & 9.08 & 9.01 & 9.39 & 9.79 \\
\hline Distillate Fuel 6/ & 8.86 & 8.88 & 8.88 & 8.90 & 8.92 & 9.01 & 9.02 & 8.97 & 9.34 & 9.72 \\
\hline Jet Fuel 7/ & 5.23 & 5.27 & 5.32 & 5.39 & 5.46 & 5.74 & 5.89 & 5.91 & 6.44 & 7.02 \\
\hline Motor Gasoline 8/ & 10.16 & 10.21 & 10.26 & 10.33 & 10.29 & 10.35 & 10.35 & 10.30 & 10.75 & 11.22 \\
\hline Residual Fuel & 3.08 & 3.09 & 3.11 & 3.13 & 3.15 & 3.21 & 3.30 & 3.39 & 3.73 & 4.10 \\
\hline Liquid Petroleum Gas 9/ & 13.52 & 13.52 & 13.56 & 13.52 & 13.51 & 13.48 & 13.47 & 13.50 & 14.14 & 14.82 \\
\hline Natural Gas 10/ & 6.23 & 6.28 & 6.39 & 6.54 & 6.71 & 7.22 & 7.45 & 7.49 & 7.92 & 8.39 \\
\hline Ethanol (E85) 11/ & 16.96 & 17.42 & 17.47 & 17.54 & 17.49 & 17.66 & 17.74 & 17.79 & 18.68 & 19.62 \\
\hline Methanol (M85) 12/ & 12.20 & 13.65 & 13.67 & 14.01 & 14.01 & 14.32 & 14.38 & 14.42 & 16.05 & 17.87 \\
\hline Electricity & 15.36 & 15.15 & 14.92 & 14.62 & 14.52 & 14.15 & 13.68 & 13.38 & 12.77 & 12.18 \\
\hline Average End-Use Energy & 8.77 & 8.77 & 8.77 & 8.76 & 8.77 & 8.81 & 8.81 & 8.81 & 8.98 & 9.16 \\
\hline Primary Energy & 8.42 & 8.42 & 8.43 & 8.43 & 8.43 & 8.49 & 8.49 & 8.49 & 8.71 & 8.93 \\
\hline Electricity & 18.49 & 18.31 & 18.16 & 17.85 & 17.85 & 17.50 & 17.24 & 17.06 & 16.54 & 16.03 \\
\hline \multicolumn{11}{|l|}{ Electric Generators 13/ } \\
\hline Fossil Fuel Average & 1.45 & 1.43 & 1.43 & 1.44 & 1.47 & 1.55 & 1.64 & 1.67 & 1.71 & 1.76 \\
\hline Petroleum Products & 3.17 & 3.21 & 3.24 & 3.23 & 3.21 & 3.28 & 3.40 & 3.54 & 3.93 & 4.37 \\
\hline Distillate Fuel & 4.89 & 4.93 & 4.96 & 4.98 & 5.03 & 5.12 & 5.10 & 5.23 & 5.85 & 6.54 \\
\hline Residual Fuel & 3.06 & 3.09 & 3.12 & 3.11 & 3.10 & 3.13 & 3.19 & 3.30 & 3.63 & 3.99 \\
\hline Natural Gas & 2.62 & 2.65 & 2.72 & 2.79 & 2.88 & 3.08 & 3.21 & 3.33 & 3.61 & 3.91 \\
\hline Steam Coal & 1.16 & 1.14 & 1.12 & 1.11 & 1.10 & 1.07 & 1.03 & 0.98 & 0.93 & 0.88 \\
\hline \multicolumn{11}{|l|}{ Average Price to All Users 14/ } \\
\hline Petroleum Products 2/ & 8.11 & 8.14 & 8.19 & 8.22 & 8.21 & 8.32 & 8.35 & 8.35 & 8.80 & 9.27 \\
\hline Distillate Fuel & 7.99 & 8.03 & 8.04 & 8.06 & 8.09 & 8.19 & 8.22 & 8.22 & 8.64 & 9.08 \\
\hline Jet Fuel & 5.23 & 5.27 & 5.32 & 5.39 & 5.46 & 5.74 & 5.89 & 5.91 & 6.44 & 7.02 \\
\hline Liquefied Petroleum Gas & 8.86 & 8.84 & 8.91 & 8.86 & 8.88 & 8.93 & 9.02 & 9.22 & 9.59 & 9.98 \\
\hline Motor Gasoline 8/ & 10.16 & 10.21 & 10.26 & 10.33 & 10.29 & 10.35 & 10.35 & 10.30 & 10.75 & 11.22 \\
\hline Residual Fuel & 3.11 & 3.13 & 3.16 & 3.16 & 3.17 & 3.23 & 3.31 & 3.40 & 3.73 & 4.10 \\
\hline Natural Gas & 4.17 & 4.17 & 4.21 & 4.23 & 4.27 & 4.29 & 4.26 & 4.31 & 4.40 & 4.50 \\
\hline Coal & 1.18 & 1.15 & 1.14 & 1.13 & 1.12 & 1.09 & 1.04 & 0.99 & 0.94 & 0.89 \\
\hline Ethanol (E85) 11/ & 16.96 & 17.42 & 17.47 & 17.54 & 17.49 & 17.66 & 17.74 & 17.79 & 18.68 & 19.62 \\
\hline Methanol (M85) 12/ & 12.20 & 13.65 & 13.67 & 14.01 & 14.01 & 14.32 & 14.38 & 14.42 & 16.05 & 17.87 \\
\hline Electricity & 18.49 & 18.31 & 18.16 & 17.85 & 17.85 & 17.50 & 17.24 & 17.06 & 16.54 & 16.03 \\
\hline
\end{tabular}


Table 20. Energy Prices by Sector and Source

(1998 Dollars per Million Btu, Unless Otherwise Noted)

United States Average

\begin{tabular}{|c|c|c|c|c|c|c|c|c|c|c|}
\hline & 2002 & 2003 & 2004 & 2005 & 2006 & 2010 & 2015 & 2020 & 2025 & 2030 \\
\hline \multicolumn{11}{|l|}{$\begin{array}{l}\text { Non-Renewable Energy Expentures } \\
\text { by Sector (billion } 1998 \text { dollars) }\end{array}$} \\
\hline Residential & 139.62 & 140.76 & 142.55 & 142.85 & 144.61 & 150.04 & 155.58 & 161.86 & 169.81 & 178.15 \\
\hline Commercial & 100.15 & 100.53 & 101.02 & 101.07 & 102.27 & 105.14 & 108.63 & 109.62 & 112.75 & 115.96 \\
\hline Industrial & 112.64 & 114.83 & 116.87 & 118.54 & 120.66 & 126.14 & 134.52 & 142.83 & 154.45 & 167.02 \\
\hline Transportation & 243.85 & 249.41 & 255.95 & 262.48 & 267.19 & 288.11 & 309.47 & 326.66 & 370.30 & 419.78 \\
\hline Total Non-Renewable Expend & 596.26 & 605.53 & 616.38 & 624.94 & 634.74 & 669.44 & 708.19 & 740.97 & 804.02 & 872.45 \\
\hline Total Expenditures & 596.56 & 605.91 & 616.86 & 625.50 & 635.40 & 670.44 & 709.50 & 742.38 & 805.89 & 874.83 \\
\hline
\end{tabular}

$1 /$ Weighted average price includes fuels below as well as coal.

2/ This quantity is the weighted average for all petroleum products, not just those listed below.

3/ Excludes independent power producers.

4/ Includes cogenerators.

5/ Excludes uses for lease and plant fuel.

6/ Low sulfur diesel fuel. Price includes Federal and State taxes while excluding county and local taxes.

7/ Kerosene-type jet fuel. Price includes Federal and State taxes while excluding county and local taxes.

8/ Sales weighted-average price for all grades. Includes Federal and State taxes and assumes county and

local taxes of 2 cents per gallon.

9/ Includes Federal and State taxes while excluding county and local taxes.

10/ Compressed natural gas used as a vehicle fuel. Price includes estimated motor vehicle fuel taxes.

11/ E85 is 85 percent ethanol (renewable) and 15 percent motor gasoline (nonrenewable).

$12 /$ M85 is 85 percent methanol and 15 percent motor gasoline.

13 / Includes all electric power generators except cogenerators, which produce electricity and other useful thermal energy. Includes small power producers and exempt wholesale generators.

14 / Weighted averages of end-use fuel prices are derived from the prices shown in each sector and the corresponding sectoral consumption.

Btu = British thermal unit.

Note: Totals may not equal sum of components due to independent rounding.

The historical data used were the most current available as of July 31, 1999. At that time, most regional data for 1998 were not available. The numbers presented for 1998 are estimates and may differ from official EIA data reports. Also, please see EIA data publications and the Short-Term Energy Outlook for the latest estimates for 1999.

Sources: 1998 prices for gasoline, distillate, and jet fuel are based on prices in various issues of Energy Information Administration (EIA), Petroleum Marketing Monthly, DOE/EIA-0380 (98/03-99/04) (Washington, DC, 1998-99). 1998 prices for all other petroleum products are derived from the EIA,State Energy Price and Expenditure Report 1995, DOE/EIA-0376(95) (Washington, DC, August 1998). 1997 and 1998 industrial gas delivered prices are based on EIA, Manufacturing Energy Consumption Survey 1994. 1998 residential and commercial natural gas delivered prices: EIA Natural Gas Monthly, DOE/EIA-0130(99/06) (Washington, DC, June 1999). 1998 coal prices based on EIA, Quarterly Coal Report , DOE/EIA-0121(99/1Q) (Washington, DC, August 1999), and EIA, AEO 2000 National Energy Modeling System run AEO2K.D100199A. 1998 electricity prices for commercial, industrial, and transportation: EIA, AEO2000 National Energy Modeling System run AEO2K.D100199A. Projections: EIA, AEO2000 National Energy Modeling System run AEO2K.D100199A. 
Table 21. Residential Sector Supplement Table

$\begin{array}{llllllllll}2002 & 2003 & 2004 & 2005 & 2006 & 2010 & 2015 & 2020 & 2025 & 2030\end{array}$

Equipment Stock (million units)

Main Space Heaters

Electric Heat Pumps

Electric Other

Natural Gas Heat Pumps

Natural Gas Other

Distillate

Liquid Petroleum Gas

Kerosene

Wood Stoves

Geothermal Heat Pumps

Total

Space Cooling (million units)

Electric Heat Pumps

Natural Gas Heat Pumps

Geothermal Heat Pumps

Central Air Conditioners

Room Air Conditioners

Total

Water Heaters (million units)

10.47

10.88
20.77

11.02

11.15

0.63

0.14

20.88

20.99

57.63
9.25

$58.45 \quad 59.27$

21.50

60.20

$9.21 \quad 9.16$

9.11

$\begin{array}{ll}9.06 & 8.84\end{array}$

5.02

0.92

5.12

5.15

5.17

0.89

0.88

$2.16 \quad 2.1$

2.16

2.15

2.14

0.48
106.54

0.51
107.73

108.94

110.17

11.38

5.23

0.85

2.12

0.92

$10.47 \quad 10.67$

$0.10 \quad 0.12$

$0.48 \quad 0.51$

44.02

37.15

92.23

37.18

11.02

$$
\begin{array}{r}
11.15 \\
0.19
\end{array}
$$

116.03

$12.32 \quad 12.98$

$22.17 \quad 22.81$

13.91

23.49

14.90

$139-3.00$

$\begin{array}{llll}68.60 & 72.26 & 77.09 & 82.25\end{array}$

$\begin{array}{llll}8.57 & 8.27 & 8.03 & 7.79\end{array}$

$\begin{array}{llll}5.22 & 5.17 & 5.27 & 5.38\end{array}$

$\begin{array}{llll}0.81 & 0.77 & 0.73 & 0.70\end{array}$

$\begin{array}{llll}2.11 & 2.12 & 2.10 & 2.09\end{array}$

$\begin{array}{lrrr}1.22 & 1.50 & 2.05 & 2.81\end{array}$

$121.45 \quad 126.51 \quad 132.96$

139.74

0.17

0.60

46.89

$1.15 \quad 11.65$

12.32

$\begin{array}{lll}0.67 & 0.92 & 1.22\end{array}$

$47.85-51.50 \quad 55.70$

$37.31 \quad 37.52$

$\begin{array}{rr}37.80 & 38.06 \\ 107.47 & 112.71\end{array}$

95.94

$97.16 \quad 101.87$

$13.91 \quad 14.90$

$\begin{array}{ll}1.39 & 3.00\end{array}$

$2.05 \quad 2.81$

$65.13 \quad 71.25$

$38.29 \quad 38.52$

$119.50 \quad 126.69$

Electric

Natural Gas

Distillate

Liquid Petroleum Gas

Solar Thermal

Total

Cooking Equipment (million units) 1/

Electric

Natural Gas

Liquid Petroeum Gas

Total

Clothes Dryers (million units)

Electric

Natural Gas

Total

$\begin{array}{rrr}41.69 & 42.10 & 42.5 \\ 56.45 & 57.18 & 57 . \\ 5.06 & 5.04 & 5 . \\ 3.68 & 3.73 & 3.7 \\ 0.35 & 0.35 & 0.3 \\ 107.22 & 108.40 & 109.6\end{array}$

Other Appliances (million units)

Refrigerators

Freezers

66.08

$\begin{array}{lll}66.08 & 66.81 \quad 67.54\end{array}$

35.90

4.52

106.49

36.32
4.55
107.68

36.76

$$
4.58
$$

108.89

42.90

58.77

4.99

3.82

0.35

110.83

$43.27 \quad 44.79$

$59.59 \quad 62.74$

$4.97 \quad 4.85$

$3.86 \quad 3.95$

0.34

112.04

0.34

116.67

46.71

66.36

4.69

3.98

0.33
122.07

122.07

48.48

69.78

4.53

3.99

0.32

127.11

68.27

37.25

4.60

68.99

37.73

71.82

75.04

41.80

4.56

78.27

43.68

4.50

126.45

$111.33 \quad 115.97$

121.4

$61.71 \quad 62.82 \quad 63.94$

$\begin{array}{lll}17.43 & 17.83 & 18 .\end{array}$

$79.14 \quad 80.65$

65.05

18.65

66.15

85.

82.17

83.70

85.20

20.64

90.90

74.93

103.55

121.

33.

122.7

33.56

124.01

33.5

125.29

33.51

126.54

33.51

131.33

33.47

136.89

33.73

142.07

34.36

$148.63 \quad 155.49$

Stock Average Equipment Efficiency

Main Space Heaters

Electric Heat Pumps (HSPF)

Natural Gas Heat Pumps (HSPF)

Geothermal Heat Pumps (COP)

Natural Gas Furnace (AFUE)

Distillate Furnace (AFUE)

Space Cooling

Electric Heat Pumps (SEER)

Natural Gas Heat Pumps (SEER)

Geothermal Heat Pumps (EER)

Cent. Air Conditioners (SEER)

Room Air Conditioners (EER)

Water Heaters

Electric (EF)

Natural Gas (EF)

Distillate (EF)

Liquid Petroleum Gas (EF)

$\begin{array}{rrrrrrrrrr}7.19 & 7.22 & 7.23 & 7.24 & 7.25 & 7.24 & 7.30 & 7.43 & 7.54 & 7.66 \\ 14.00 & 14.00 & 14.00 & 14.00 & 14.00 & 14.00 & 14.00 & 14.00 & 14.00 & 14.00 \\ 3.40 & 3.40 & 3.40 & 3.40 & 3.40 & 3.40 & 3.44 & 3.61 & 3.66 & 3.71 \\ 0.77 & 0.78 & 0.78 & 0.79 & 0.80 & 0.82 & 0.83 & 0.84 & 0.86 & 0.89 \\ 0.80 & 0.80 & 0.80 & 0.81 & 0.81 & 0.81 & 0.82 & 0.82 & 0.83 & 0.84 \\ & & & & & & & & & \\ 10.78 & 10.85 & 10.90 & 10.96 & 11.00 & 11.08 & 11.19 & 11.41 & 11.69 & 11.98 \\ 15.60 & 15.60 & 15.60 & 15.60 & 15.60 & 15.60 & 15.60 & 15.60 & 15.60 & 15.60 \\ 13.50 & 13.50 & 13.50 & 14.68 & 15.33 & 17.68 & 19.48 & 17.28 & 18.28 & 19.33 \\ 10.54 & 10.61 & 10.66 & 10.75 & 10.81 & 10.98 & 11.16 & 11.37 & 11.68 & 12.00 \\ 8.92 & 9.03 & 9.12 & 9.21 & 9.29 & 9.52 & 9.73 & 9.80 & 10.12 & 10.45 \\ & & & & & & & & & \\ 0.87 & 0.87 & 0.87 & 0.88 & 0.88 & 0.88 & 0.88 & 0.89 & 0.89 & 0.89 \\ 0.55 & 0.55 & 0.55 & 0.55 & 0.56 & 0.56 & 0.57 & 0.57 & 0.58 & 0.58 \\ 0.54 & 0.54 & 0.54 & 0.54 & 0.54 & 0.53 & 0.53 & 0.53 & 0.53 & 0.53 \\ 0.55 & 0.56 & 0.56 & 0.56 & 0.56 & 0.57 & 0.58 & 0.59 & 0.60 & 0.62\end{array}$


Table 21. Residential Sector Supplement Table

\begin{tabular}{|c|c|c|c|c|c|c|c|c|c|c|}
\hline & 2002 & 2003 & 2004 & 2005 & 2006 & 2010 & 2015 & 2020 & 2025 & 2030 \\
\hline \multicolumn{11}{|c|}{ Other Appliances (kilowatthours per year) } \\
\hline Refrigerators & 822.70 & 790.08 & 759.92 & 732.00 & 706.30 & 618.99 & 548.87 & 514.40 & 448.75 & 391.48 \\
\hline \multicolumn{11}{|c|}{$\begin{array}{l}\text { Building Shell Efficiency Index } \\
\text { Space Heating }\end{array}$} \\
\hline Pre-1998 Homes & 0.93 & 0.93 & 0.92 & 0.92 & 0.91 & 0.90 & 0.88 & 0.87 & 0.85 & 0.83 \\
\hline All Homes & 0.92 & 0.92 & 0.91 & 0.91 & 0.91 & 0.89 & 0.87 & 0.86 & 0.84 & 0.82 \\
\hline \multicolumn{11}{|l|}{ Space Cooling } \\
\hline Pre-1998 Homes & 0.94 & 0.93 & 0.93 & 0.93 & 0.92 & 0.91 & 0.89 & 0.88 & 0.86 & 0.85 \\
\hline New Construction & 0.86 & 0.86 & 0.86 & 0.86 & 0.86 & 0.85 & 0.82 & 0.80 & 0.78 & 0.77 \\
\hline All Homes & 0.93 & 0.92 & 0.92 & 0.92 & 0.91 & 0.90 & 0.88 & 0.87 & 0.85 & 0.83 \\
\hline
\end{tabular}

1/ Does not include microwave ovens or outdoor grills.

HSPF = Heating Seasonal Performance Factor: The total heating output of a heat pump in Btu during its normal annual usage

period for heating divided by total electric input in watt-hours during the same period.

$\mathrm{COP}=$ Coefficient of Performance: Energy efficiency rating measure determined, under specific testing conditions, by dividing the energy output by the energy input.

AFUE = Annual Fuel Utilization Efficiency: Efficiency rating based on average usage, including on and off cycling, as set out in the standardized Department of Energy test procedures.

SEER = Seasonal Energy Efficiency Ratio: The total cooling of a central unitary air conditioner or a unitary heat pump in Btu during its normal annual usage period for cooling divided by the total electric energy input in watt-hours during the same period.

EER = Energy Efficiency Ratio: A ratio calculated by dividing the cooling capacity in Btu per hour by the power input in watts at any given set of rating conditions, expressed in Btu per hour per watt.

$\mathrm{EF}=$ Efficiency Factor: Efficiency (measured in Btu out / Btu in) of water heaters under certain test conditions specified by the Department of Energy.

$\mathrm{kWh} / \mathrm{y}=$ Kilowatt hours per year to run the appliance under certain test conditions as specified by the Department of Energy.

$\mathrm{Btu}=$ British thermal unit.

$\mathrm{N} / \mathrm{A}=$ Not applicable.

Note: Totals may not equal sum of components due to independent rounding. The historical data used for the projections were the most available as of July 31, 1999. The numbers presented for 1998 are estimates and may differ from official EIA data reports. Also. please see EIA data publications and the Short-Term Energy Outlook for the latest estimates for 1999.

Source: EIA, AEO2000 National Energy Modeling System run AEO2K.D100199A. 
Table 22. Commercial Sector Supplement Table

$\begin{array}{llllllllll}2002 & 2003 & 2004 & 2005 & 2006 & 2010 & 2015 & 2020 & 2025 & 2030\end{array}$

Commercial Building Delivered

Energy Consumption (quadrillion Btu) 1/

Assembly

Education

Food Sales

Food Service

Health Care

Lodging

Office - Large

Office - Small

Mercantile/Service

Warehouse

Other

Total

$\begin{array}{llllllllll}0.53 & 0.53 & 0.53 & 0.54 & 0.54 & 0.55 & 0.56 & 0.56 & 0.57 & 0.58 \\ 0.71 & 0.72 & 0.72 & 0.73 & 0.73 & 0.76 & 0.79 & 0.79 & 0.83 & 0.86 \\ 0.15 & 0.15 & 0.15 & 0.16 & 0.16 & 0.16 & 0.17 & 0.17 & 0.18 & 0.19 \\ 0.39 & 0.39 & 0.40 & 0.40 & 0.41 & 0.42 & 0.44 & 0.45 & 0.47 & 0.49 \\ 0.55 & 0.56 & 0.57 & 0.58 & 0.59 & 0.62 & 0.66 & 0.69 & 0.73 & 0.78 \\ 0.55 & 0.56 & 0.56 & 0.57 & 0.58 & 0.61 & 0.64 & 0.66 & 0.69 & 0.73 \\ 0.69 & 0.70 & 0.71 & 0.72 & 0.72 & 0.76 & 0.79 & 0.81 & 0.84 & 0.88 \\ 0.54 & 0.55 & 0.55 & 0.56 & 0.56 & 0.59 & 0.62 & 0.62 & 0.65 & 0.69 \\ 1.13 & 1.13 & 1.14 & 1.15 & 1.16 & 1.20 & 1.24 & 1.24 & 1.29 & 1.35 \\ 0.39 & 0.40 & 0.40 & 0.41 & 0.42 & 0.44 & 0.46 & 0.47 & 0.50 & 0.53 \\ 0.50 & 0.51 & 0.52 & 0.53 & 0.54 & 0.58 & 0.63 & 0.66 & 0.72 & 0.79 \\ 6.15 & 6.20 & 6.27 & 6.34 & 6.41 & 6.70 & 7.00 & 7.11 & 7.47 & 7.85\end{array}$

Commercial Building Floorspace

(billion square feet)

Assembly

Education

Food Sales

Food Service

Health Care

Lodging

Office - Large

Office - Small

Mercantile/Service

Warehouse

Other

Total

$\begin{array}{rrr}7.15 & 7.19 & 7.24 \\ 8.62 & 8.74 & 8.86 \\ 0.71 & 0.72 & 0.73 \\ 1.47 & 1.48 & 1.50 \\ 1.85 & 1.88 & 1.91 \\ 4.15 & 4.20 & 4.26 \\ 6.04 & 6.08 & 6.11 \\ 5.73 & 5.77 & 5.81 \\ 13.98 & 14.09 & 14.23 \\ 9.62 & 9.75 & 9.87 \\ 5.60 & 5.72 & 5.82 \\ 64.93 & 65.62 & 66.34\end{array}$

7.29

7.29

8.99
0.74

0.74

$\begin{array}{ll}1.94 & 1.96\end{array}$

4.33

6.15

5.85

14.38

10.01

5.93

7.3
9.1
0.7
1.5
1.9
4.39
6.20
5.9
14.54
10.15
6.04
67.89

\subsection{9}

9.62

0.78

1.58

2.04

4.62

6.42

6.13

15.14

10.63

6.42

$\begin{array}{llll}67.11 & 67.89 & 70.87 & 73.32\end{array}$

$\begin{array}{rrrr}7.62 & 7.64 & 7.82 & 8.00 \\ 10.08 & 10.24 & 10.80 & 11.39 \\ 0.81 & 0.82 & 0.85 & 0.89 \\ 1.63 & 1.63 & 1.68 & 1.74 \\ 2.13 & 2.18 & 2.30 & 2.42 \\ 4.84 & 4.92 & 5.21 & 5.52 \\ 6.57 & 6.53 & 6.70 & 6.87 \\ 6.29 & 6.27 & 6.46 & 6.65 \\ 15.66 & 15.78 & 16.40 & 17.05 \\ 10.92 & 10.84 & 11.32 & 11.82 \\ 6.78 & 6.98 & 7.52 & 8.10 \\ 73.32 & 73.81 & 77.01 & 80.35\end{array}$

Stock Avgerage Equipmet Efficiency 2/

Space Heating
Electricity
Natural Gas
Distillate
Space Cooling
Electricity
Natural Gas
Water Heating
Electricity
Natural Gas
Distillate
Ventilation (cfm per Btu) $3 /$
Electricity
Cooking
Electricity
Natural Gas
Lighting Efficacy $4 /$
(efficacy in lumens per watt)
Electricity
Refrigeration
Electricity

\begin{tabular}{|c|c|c|c|c|c|c|c|c|c|}
\hline 1.10 & 1.11 & 1.11 & 1.12 & 1.12 & 1.13 & 1.13 & 1.13 & 1.14 & 1.16 \\
\hline 0.76 & 0.76 & 0.76 & 0.77 & 0.77 & 0.78 & 0.79 & 0.80 & 0.81 & 0.82 \\
\hline 0.76 & 0.76 & 0.76 & 0.76 & 0.76 & 0.77 & 0.77 & 0.77 & 0.78 & 0.79 \\
\hline 2.65 & 2.68 & 2.72 & 2.76 & 2.80 & 2.93 & 3.06 & 3.16 & 3.34 & 3.53 \\
\hline 0.95 & 0.96 & 0.97 & 0.99 & 1.01 & 1.07 & 1.12 & 1.16 & 1.23 & 1.31 \\
\hline 0.95 & 0.95 & 0.95 & 0.96 & 0.96 & 0.96 & 0.97 & 0.97 & 0.98 & 0.99 \\
\hline 0.76 & 0.76 & 0.77 & 0.77 & 0.78 & 0.79 & 0.80 & 0.80 & 0.82 & 0.84 \\
\hline 0.75 & 0.76 & 0.76 & 0.76 & 0.76 & 0.77 & 0.77 & 0.77 & 0.78 & 0.79 \\
\hline 0.41 & 0.41 & 0.41 & 0.41 & 0.41 & 0.43 & 0.44 & 0.45 & 0.47 & 0.48 \\
\hline 0.53 & 0.53 & 0.53 & 0.53 & 0.53 & 0.53 & 0.53 & 0.53 & 0.53 & 0.54 \\
\hline 0.50 & 0.50 & 0.50 & 0.50 & 0.50 & 0.50 & 0.50 & 0.50 & 0.50 & 0.50 \\
\hline 51.91 & 52.68 & 53.40 & 53.97 & 54.54 & 56.28 & 57.68 & 59.53 & 62.21 & 65.02 \\
\hline 1.32 & 1.33 & 1.33 & 1.33 & 1.34 & 1.35 & 1.36 & 1.36 & 1.37 & 1.39 \\
\hline
\end{tabular}

1/ Excludes commercial sector energy consumption (from uses such as street lights) that is not attributable to buildings. 2/ Unless noted otherwise, the efficiency measures are in the terms of Btu of energy output divided by Btu of energy input.

$3 /$ The efficiency measure for ventilation is in terms of cubic feet per minute (cfm) of ventilation air delivered divided by Btu of energy input.

4/ A measurement of the ratio of light produced by a light source to the electrical power used to produce that quality of light, expressed in lumens per watt. 


\section{Table 22. Commercial Sector Supplement Table}

Quad. = Quadrillion.

Btu = British thermal unit.

Avg. = Average.

Equip. = Equipment.

Cfm $=$ Cubic feet per minute.

$\mathrm{PC}=$ Personal computer.

Note: Totals may not equal sum of components due to independent rounding. The historical data used for the projections were the most available as of July 31, 1999. The numbers presented for 1998 are estimates and may differ from official EIA data reports. Also. please see EIA data publications and the Short-Term Energy Outlook for the latest estimates for 1999.

Source: EIA, AEO2000 National Energy Modeling System run AEO2K.D100199A. 
Table 23. Industrial Sector Macroeconomic Indicators

\begin{tabular}{|c|c|c|c|c|c|c|c|c|c|c|}
\hline & 2002 & 2003 & 2004 & 2005 & 2006 & 2010 & 2015 & 2020 & 2025 & 2030 \\
\hline GDP (billion 1992 dollars) & 8377.2 & 8595.9 & 8823.8 & 9056.3 & 9250.8 & 10054.3 & 11147.2 & 12178.6 & 13575.82 & 15133.34 \\
\hline Non-Agricultural Employment (million) & 131.2 & 132.6 & 133.9 & 135.3 & 136.5 & 140.1 & 144.6 & 147.8 & 153.24 & 158.86 \\
\hline \multicolumn{11}{|l|}{$\begin{array}{l}\text { Value of Gross Output } \\
\text { (billion } 1987 \text { dollars) }\end{array}$} \\
\hline \multicolumn{11}{|l|}{ Nonmanufacturing Sector } \\
\hline Agricultural & 270.8 & 273.8 & 277.3 & 280.6 & 283.3 & 294.6 & 312.6 & 329.7 & 348.51 & 368.36 \\
\hline Mining & 135.8 & 137.5 & 138.8 & 140.6 & 142.3 & 148.1 & 156.6 & 161.9 & 168.14 & 174.60 \\
\hline Construction & 473.3 & 483.0 & 496.9 & 510.8 & 520.3 & 546.4 & 597.7 & 638.9 & 695.54 & 757.24 \\
\hline \multicolumn{11}{|l|}{ Manufacturing Sector } \\
\hline Food and Kindred Products & 429.9 & 433.6 & 437.7 & 442.6 & 446.7 & 462.3 & 488.9 & 516.2 & 544.05 & 573.34 \\
\hline Tobacco Products & 27.2 & 27.1 & 26.9 & 26.7 & 26.3 & 25.0 & 23.8 & 22.3 & 21.16 & 20.07 \\
\hline \multicolumn{11}{|l|}{ Apparel and Other Textile } \\
\hline Products & 78.6 & 78.4 & 77.9 & 77.4 & 75.8 & 72.4 & 68.4 & 67.0 & 63.28 & 59.78 \\
\hline Lumber and Wood Products & 84.5 & 86.2 & 87.3 & 88.6 & 89.3 & 90.8 & 94.6 & 96.7 & 101.21 & 105.93 \\
\hline Furniture and Fixtures & 51.0 & 52.2 & 52.9 & 53.5 & 53.2 & 54.7 & 59.4 & 63.1 & 67.61 & 72.47 \\
\hline Paper and Allied Products & 136.7 & 139.1 & 141.2 & 143.4 & 145.1 & 150.9 & 158.8 & 165.6 & 175.65 & 186.35 \\
\hline Printing and Publishing & 145.6 & 147.2 & 148.8 & 150.4 & 151.4 & 155.3 & 162.1 & 168.2 & 174.56 & 181.12 \\
\hline Chemical and Allied Products & 306.9 & 314.9 & 320.7 & 326.5 & 331.1 & 352.7 & 382.4 & 412.3 & 447.22 & 485.09 \\
\hline Bulk Chemicals & 160.1 & 163.6 & 165.9 & 168.1 & 170.1 & 178.5 & 189.1 & 197.8 & 208.92 & 220.65 \\
\hline \multicolumn{11}{|l|}{ Other Chemicals and } \\
\hline Allied Products & 146.8 & 151.2 & 154.8 & 158.3 & 161.0 & 174.3 & 193.3 & 214.5 & 239.19 & 266.74 \\
\hline Petroleum and Coal Products & 163.3 & 164.4 & 167.1 & 169.7 & 172.0 & 176.9 & 180.1 & 183.1 & 189.85 & 196.80 \\
\hline \multicolumn{11}{|l|}{ Other Petroleum and } \\
\hline Coal Products & 16.5 & 16.7 & 16.9 & 17.2 & 17.3 & 17.9 & 18.8 & 19.5 & 20.50 & 21.54 \\
\hline \multicolumn{11}{|l|}{ Rubber and Miscellaneous } \\
\hline Plastic Products & 147.3 & 153.8 & 159.4 & 165.1 & 169.7 & 189.2 & 215.3 & 237.9 & 271.52 & 309.94 \\
\hline Leather and Leather Products & 5.3 & 5.1 & 4.7 & 4.3 & 3.9 & 3.0 & 2.1 & 1.5 & 1.04 & 0.74 \\
\hline \multicolumn{11}{|l|}{ Other Stone, Clay, and } \\
\hline Glass Products & 49.8 & 50.5 & 51.4 & 52.2 & 52.6 & 53.2 & 54.9 & 55.7 & 57.85 & 60.05 \\
\hline \multicolumn{10}{|l|}{ Blast Furnace and Basic } & 181.80 \\
\hline Steel Products & 69.2 & 70.9 & 72.3 & 73.4 & 73.2 & 74.5 & 76.1 & 77.0 & 79.23 & 81.49 \\
\hline Aluminum & 30.8 & 30.9 & 31.3 & 31.5 & 31.6 & 32.0 & 32.8 & 33.3 & 34.11 & 34.91 \\
\hline Other Primary Metal Products & 53.8 & 55.0 & 55.8 & 56.6 & 56.8 & 58.4 & 60.3 & 60.7 & 63.03 & 65.44 \\
\hline $\begin{array}{l}\text { Fabricated Metal Products } \\
\text { Industrial Machinery and }\end{array}$ & 198.8 & 205.7 & 209.4 & 213.7 & 215.9 & 223.7 & 236.1 & 243.3 & 258.43 & 274.49 \\
\hline \multicolumn{10}{|l|}{ Electronic and Other Electric } & 804.75 \\
\hline Equipment & 494.8 & 529.4 & 559.3 & 588.7 & 620.8 & 741.2 & 892.4 & 1027.5 & 1281.35 & 1597.89 \\
\hline Transportation Equipment & 422.3 & 443.3 & 452.7 & 465.9 & 473.3 & 522.6 & 588.0 & 636.6 & 697.83 & 764.94 \\
\hline $\begin{array}{l}\text { Instruments \& Related Products } \\
\text { Miscellaneous Manufacturing }\end{array}$ & 142.9 & 147.3 & 151.1 & 154.8 & 159.0 & 177.1 & 199.5 & 214.4 & 240.57 & 269.94 \\
\hline Industries & 45.5 & 45.9 & 46.6 & 47.2 & 47.3 & 48.7 & 53.2 & 54.9 & 57.96 & 61.18 \\
\hline Total Industrial Gross Output & 4426.0 & 4554.6 & 4659.5 & 4769.9 & 4857.3 & 5216.4 & 5730.1 & 6170.9 & 6762.14 & 7410.00 \\
\hline $\begin{array}{l}\text { GDP = Gross domestic product. } \\
\text { Note: Totals may not equal sum of c } \\
\text { available as of July } 31,1999 \text {. The num } \\
\text { see EIA data publications and the Shor } \\
\text { Sources: } 1998 \text { : Standard \& Poors DR }\end{array}$ & $\begin{array}{l}\text { due } t \\
\text { nted fo } \\
\text { rgy Ou } \\
\mathrm{T} 25\end{array}$ & $\begin{array}{l}\text { depenc } \\
998 \text { are } \\
\text { ok for t } \\
\text { 9. Proj }\end{array}$ & $\begin{array}{l}\text { roundi } \\
\text { mates } \\
\text { test es } \\
\text { ns: En }\end{array}$ & $\begin{array}{l}\text { The h } \\
\text { d may } \\
\text { ates fo } \\
\text { Inforn }\end{array}$ & $\begin{array}{l}\text { ical dat } \\
\text { r from o } \\
99 . \\
\text { on Adm }\end{array}$ & $\begin{array}{l}\text { sed for } \\
\text { ial EIA C }\end{array}$ & $\begin{array}{l}\text { he project } \\
\text { ata report }\end{array}$ & ins were & most & \\
\hline
\end{tabular}


Table 24. Refining Industry Energy Consumption

\begin{tabular}{|c|c|c|c|c|c|c|c|c|c|c|}
\hline & 2002 & 2003 & 2004 & 2005 & 2006 & 2010 & 2015 & 2020 & 2025 & 2030 \\
\hline Industry Output (billion 1987 dollars ) & 146.78 & 147.63 & 150.14 & 152.56 & 154.62 & 159.01 & 161.25 & 163.63 & 169.36 & 175.29 \\
\hline \multicolumn{11}{|l|}{ Energy Consumption (trillion Btu) } \\
\hline Residual Oil & 12.0 & 12.0 & 12.0 & 11.9 & 25.9 & 40.6 & 41.6 & 43.0 & 46.30 & 49.82 \\
\hline Distillate Oil & 0.0 & 0.0 & 0.0 & 0.0 & 0.0 & 0.0 & 0.0 & 0.0 & 0.0 & 0.0 \\
\hline Liquefied Petroleum Gas & 6.2 & 0.0 & 0.0 & 0.0 & 0.0 & 15.7 & 6.9 & 6.9 & 5.87 & 4.99 \\
\hline Still Gas & 1603.4 & 1602.3 & 1572.4 & 1554.1 & 1548.3 & 1487.4 & 1471.4 & 1463.8 & 1471.32 & 1478.91 \\
\hline Other Petroleum 2/ & 33.9 & 32.7 & 32.4 & 31.6 & 31.1 & 15.2 & 26.0 & 24.6 & 23.09 & 21.64 \\
\hline Petroleum Subtotal & 2277.3 & 2259.7 & 2286.7 & 2310.9 & 2340.6 & 2377.4 & 2387.3 & 2377.1 & 2444.37 & 2513.50 \\
\hline Natural Gas & 906.2 & 920.8 & 930.5 & 942.2 & 954.8 & 971.3 & 960.0 & 950.2 & 961.39 & 972.69 \\
\hline Steam Coal & 0.0 & 0.0 & 0.0 & 0.0 & 0.0 & 0.0 & 0.0 & 0.0 & 0.0 & 0.0 \\
\hline Purchased Electricity & 128.1 & 129.0 & 128.1 & 128.2 & 131.4 & 128.9 & 123.2 & 117.4 & 118.81 & 120.28 \\
\hline Total & 3311.6 & 3309.5 & 3345.3 & 3381.4 & 3426.8 & 3477.6 & 3470.4 & 3444.7 & 3523.84 & 3604.76 \\
\hline Residual Oil & 0.08 & 0.08 & 0.08 & 0.08 & 0.17 & 0.26 & 0.26 & 0.26 & 0.27 & 0.28 \\
\hline Distillate Oil & 0.00 & 0.00 & 0.00 & 0.00 & 0.00 & 0.00 & 0.00 & 0.00 & 0.00 & 0.00 \\
\hline Liquefied Petroleum Gas & 0.04 & 0.00 & 0.00 & 0.00 & 0.00 & 0.10 & 0.04 & 0.04 & 0.03 & 0.03 \\
\hline Petroleum Coke & 4.24 & 4.15 & 4.46 & 4.68 & 4.76 & 5.15 & 5.22 & 5.13 & 5.37 & 5.62 \\
\hline Still Gas & 10.92 & 10.85 & 10.47 & 10.19 & 10.01 & 9.35 & 9.13 & 8.95 & 8.69 & 8.44 \\
\hline Other Petroleum 2/ & 0.23 & 0.22 & 0.22 & 0.21 & 0.20 & 0.10 & 0.16 & 0.15 & 0.14 & 0.12 \\
\hline Petroleum Subtotal & 15.52 & 15.31 & 15.23 & 15.15 & 15.14 & 14.95 & 14.80 & 14.53 & 14.43 & 14.34 \\
\hline Natural Gas & 6.17 & 6.24 & 6.20 & 6.18 & 6.18 & 6.11 & 5.95 & 5.81 & 5.68 & 5.55 \\
\hline Steam Coal & 0.00 & 0.00 & 0.00 & 0.00 & 0.00 & 0.00 & 0.00 & 0.00 & 0.00 & 0.00 \\
\hline Purchased Electricity & 0.87 & 0.87 & 0.85 & 0.84 & 0.85 & 0.81 & 0.76 & 0.72 & 0.70 & 0.69 \\
\hline Total & 22.56 & 22.42 & 22.28 & 22.16 & 22.16 & 21.87 & 21.52 & 21.05 & 20.81 & 20.56 \\
\hline Carbon Emissions (billion kilograms) & 57.3 & 57.3 & 57.7 & 58.1 & 59.0 & 59.3 & 59.0 & 58.4 & 59.60 & 60.84 \\
\hline
\end{tabular}

1/ Fuel consumption includes consumption for cogeneration.

2/ Includes lubricants and miscellaneous petroleum products.

Btu $=$ British thermal unit.

N/A = Not applicable.

Note: Totals may not equal sum of components due to independent rounding. The historical data used for the projections were the most available as of July 31, 1999. The numbers presented for 1998 are estimates and may differ from official EIA data reports. Also. please see EIA data publications and the Short-Term Energy Outlook for the latest estimates for 1999.

Source: Energy Information Administration, AEO2000 National Energy Modeling System run AEO2K.D100199A. 
Table 25. Food Industry Energy Consumption

\begin{tabular}{|c|c|c|c|c|c|c|c|c|c|c|}
\hline & 2002 & 2003 & 2004 & 2005 & 2006 & 2010 & 2015 & 2020 & 2025 & 2030 \\
\hline Industry Output (billion 1987 dollars) & 429.94 & 433.59 & 437.69 & 442.61 & 446.68 & 462.30 & 488.87 & 516.25 & 544.05 & 573.34 \\
\hline \multicolumn{11}{|l|}{ Energy Consumption (trillion Btu) } \\
\hline Residual Oil & 26.2 & 26.4 & 26.7 & 27.1 & 27.5 & 28.2 & 29.5 & 30.9 & 32.04 & 33.18 \\
\hline Distillate Oil & 19.4 & 19.6 & 19.9 & 20.2 & 20.4 & 20.9 & 21.8 & 22.8 & 23.51 & 24.23 \\
\hline Liquefied Petroleum Gas & 5.2 & 5.2 & 5.4 & 5.5 & 5.6 & 5.7 & 5.9 & 6.2 & 6.36 & 6.54 \\
\hline Petroleum Subtotal & 145.5 & 147.4 & 149.6 & 152.5 & 155.0 & 161.6 & 172.3 & 184.2 & 194.64 & 205.68 \\
\hline Natural Gas & 682.0 & 684.3 & 686.4 & 689.3 & 691.2 & 704.1 & 739.3 & 778.7 & 810.09 & 842.72 \\
\hline Steam Coal & 158.6 & 158.9 & 159.3 & 159.8 & 160.2 & 161.3 & 162.6 & 164.4 & 166.17 & 167.95 \\
\hline Renewables & 13.1 & 13.2 & 13.3 & 13.5 & 13.6 & 14.1 & 15.0 & 15.9 & 16.88 & 17.88 \\
\hline Purchased Electricity & 220.2 & 222.1 & 224.2 & 227.1 & 229.1 & 236.4 & 249.3 & 263.8 & 277.84 & 292.67 \\
\hline Total & 1219.3 & 1225.8 & 1232.9 & 1242.1 & 1249.2 & 1277.5 & 1338.5 & 1407.0 & 1464.97 & 1525.31 \\
\hline \multicolumn{11}{|l|}{$\begin{array}{l}\text { Energy Consumption per Unit of Output } \\
\text { (thousand Btu per } 1987 \text { dollar of output) }\end{array}$} \\
\hline Residual Oil & 0.06 & 0.06 & 0.06 & 0.06 & 0.06 & 0.06 & 0.06 & 0.06 & 0.06 & 0.06 \\
\hline Distillate Oil & 0.05 & 0.05 & 0.05 & 0.05 & 0.05 & 0.05 & 0.04 & 0.04 & 0.04 & 0.04 \\
\hline Liquefied Petroleum Gas & 0.01 & 0.01 & 0.01 & 0.01 & 0.01 & 0.01 & 0.01 & 0.01 & 0.01 & 0.01 \\
\hline Other Petroleum 2/ & 0.22 & 0.22 & 0.22 & 0.23 & 0.23 & 0.23 & 0.24 & 0.24 & 0.24 & 0.25 \\
\hline Petroleum Subtotal & 0.34 & 0.34 & 0.34 & 0.34 & 0.35 & 0.35 & 0.35 & 0.36 & 0.36 & 0.36 \\
\hline Natural Gas & 1.59 & 1.58 & 1.57 & 1.56 & 1.55 & 1.52 & 1.51 & 1.51 & 1.49 & 1.47 \\
\hline Steam Coal & 0.37 & 0.37 & 0.36 & 0.36 & 0.36 & 0.35 & 0.33 & 0.32 & 0.31 & 0.29 \\
\hline Renewables & 0.03 & 0.03 & 0.03 & 0.03 & 0.03 & 0.03 & 0.03 & 0.03 & 0.03 & 0.03 \\
\hline Purchased Electricity & 0.51 & 0.51 & 0.51 & 0.51 & 0.51 & 0.51 & 0.51 & 0.51 & 0.51 & 0.51 \\
\hline Total & 2.84 & 2.83 & 2.82 & 2.81 & 2.80 & 2.76 & 2.74 & 2.73 & 2.69 & 2.66 \\
\hline Carbon Emissions (billion kilograms) & 28.1 & 28.4 & 28.6 & 28.8 & 29.0 & 29.6 & 31.0 & 32.6 & 34.05 & 35.60 \\
\hline
\end{tabular}

1/ Fuel consumption includes consumption for cogeneration.

2/ Includes petroleum coke, lubricants, and miscellaneous petroleum products.

$\mathrm{Btu}=$ British thermal unit.

$\mathrm{N} / \mathrm{A}=$ Not applicable.

Note: Totals may not equal sum of components due to independent rounding. The historical data used for the projections were the most available as of July 31, 1999. The numbers presented for 1998 are estimates and may differ from official EIA data reports. Also. please see EIA data publications and the Short-Term Energy Outlook for the latest estimates for 1999.

Source: Energy Information Administration, AEO2000 National Energy Modeling System run AEO2K.D100199A. 
Table 26. Paper Industry Energy Consumption

\begin{tabular}{|c|c|c|c|c|c|c|c|c|c|c|}
\hline & 2002 & 2003 & 2004 & 2005 & 2006 & 2010 & 2015 & 2020 & 2025 & 2030 \\
\hline Industry Output (billion 1987 dollar) & 136.66 & 139.09 & 141.24 & 143.41 & 145.05 & 150.89 & 158.78 & 165.56 & 175.65 & 186.35 \\
\hline \multicolumn{11}{|l|}{ Energy Consumption (trillion Btu) } \\
\hline Residual Oil & 153.3 & 154.6 & 156.0 & 157.8 & 158.9 & 158.7 & 160.9 & 166.7 & 168.39 & 170.14 \\
\hline Distillate Oil & 11.7 & 11.8 & 12.0 & 12.1 & 12.2 & 12.3 & 12.5 & 13.0 & 13.20 & 13.41 \\
\hline Liquefied Petroleum Gas & 3.6 & 3.6 & 3.7 & 3.8 & 3.9 & 3.9 & 4.0 & 4.1 & 4.18 & 4.28 \\
\hline Petroleum Subtotal & 168.6 & 170.1 & 171.7 & 173.7 & 175.0 & 174.9 & 177.4 & 183.7 & 185.77 & 187.83 \\
\hline Natural Gas & 670.8 & 674.8 & 676.0 & 676.7 & 674.3 & 665.3 & 671.6 & 693.1 & 703.77 & 714.62 \\
\hline Steam Coal & 298.3 & 296.3 & 294.3 & 292.4 & 290.5 & 282.9 & 277.2 & 276.6 & 270.33 & 264.21 \\
\hline Renewables & 1458.5 & 1482.7 & 1504.6 & 1526.8 & 1543.6 & 1604.2 & 1684.8 & 1753.4 & 1853.39 & 1959.12 \\
\hline Purchased Electricity & 265.6 & 268.8 & 271.7 & 274.9 & 277.0 & 284.1 & 295.6 & 308.5 & 322.92 & 338.03 \\
\hline Total & 2861.8 & 2892.6 & 2918.3 & 2944.5 & 2960.4 & 3011.4 & 3106.5 & 3215.3 & 3330.23 & 3449.29 \\
\hline \multicolumn{11}{|l|}{$\begin{array}{l}\text { Energy Consumption per Unit of Output } \\
\text { (thousand Btu per } 1987 \text { dollar of output) }\end{array}$} \\
\hline Residual Oil & 1.12 & 1.11 & 1.10 & 1.10 & 1.10 & 1.05 & 1.01 & 1.01 & 0.96 & 0.91 \\
\hline Distillate Oil & 0.09 & 0.09 & 0.08 & 0.08 & 0.08 & 0.08 & 0.08 & 0.08 & 0.08 & 0.07 \\
\hline Liquefied Petroleum Gas & 0.03 & 0.03 & 0.03 & 0.03 & 0.03 & 0.03 & 0.03 & 0.02 & 0.02 & 0.02 \\
\hline Other Petroleum 2/ & 0.00 & 0.00 & 0.00 & 0.00 & 0.00 & 0.00 & 0.00 & 0.00 & 0.00 & 0.00 \\
\hline Petroleum Subtotal & 1.23 & 1.22 & 1.22 & 1.21 & 1.21 & 1.16 & 1.12 & 1.11 & 1.06 & 1.01 \\
\hline Natural Gas & 4.91 & 4.85 & 4.79 & 4.72 & 4.65 & 4.41 & 4.23 & 4.19 & 4.01 & 3.83 \\
\hline Steam Coal & 2.18 & 2.13 & 2.08 & 2.04 & 2.00 & 1.87 & 1.75 & 1.67 & 1.54 & 1.42 \\
\hline Renewables & 10.67 & 10.66 & 10.65 & 10.65 & 10.64 & 10.63 & 10.61 & 10.59 & 10.55 & 10.51 \\
\hline Purchased Electricity & 1.94 & 1.93 & 1.92 & 1.92 & 1.91 & 1.88 & 1.86 & 1.86 & 1.84 & 1.81 \\
\hline Total & 20.94 & 20.80 & 20.66 & 20.53 & 20.41 & 19.96 & 19.56 & 19.42 & 18.96 & 18.51 \\
\hline Carbon Emissions (billion kilograms) & 34.5 & 34.8 & 34.9 & 35.1 & 35.1 & 34.9 & 35.6 & 36.6 & 37.41 & 38.21 \\
\hline
\end{tabular}

1/ Fuel consumption includes consumption for cogeneration.

2/ Includes petroleum coke, lubricants, and miscellaneous petroleum products.

$\mathrm{Btu}=$ British thermal unit.

$\mathrm{N} / \mathrm{A}=$ Not applicable.

Note: Totals may not equal sum of components due to independent rounding. The historical data used for the projections were the most available as of July 31, 1999. The numbers presented for 1998 are estimates and may differ from official EIA data reports. Also. please see EIA data publications and the Short-Term Energy Outlook for the latest estimates for 1999.

Source: Energy Information Administration, AEO99 National Energy Modeling System run AEO2000.D100198A. 
Table 27. Bulk Chemical Industry Energy Consumption

\begin{tabular}{|c|c|c|c|c|c|c|c|c|c|c|}
\hline & 2002 & 2003 & 2004 & 2005 & 2006 & 2010 & 2015 & 2020 & 2025 & 2030 \\
\hline Industry Output (billion1987 dollars) & 160.07 & 163.61 & 165.88 & 168.14 & 170.09 & 178.46 & 189.06 & 197.83 & 208.92 & 220.65 \\
\hline \multicolumn{11}{|l|}{ Energy Consumption (trillion Btu) } \\
\hline \multicolumn{11}{|l|}{ Heat and Power } \\
\hline Residual Oil & 51.2 & 52.3 & 53.2 & 54.3 & 55.3 & 58.2 & 61.6 & 64.6 & 67.50 & 70.52 \\
\hline Distillate Oil & 5.8 & 5.9 & 6.0 & 6.1 & 6.2 & 6.4 & 6.7 & 6.9 & 7.01 & 7.11 \\
\hline Other Petroleum 2/ & 470.8 & 481.3 & 489.9 & 500.3 & 510.0 & 538.6 & 573.6 & 606.9 & 640.79 & 676.58 \\
\hline Petroleum Subtotal & 529.5 & 541.2 & 550.9 & 562.5 & 573.4 & 605.2 & 644.0 & 680.6 & 717.53 & 756.46 \\
\hline Natural Gas & 1833.4 & 1865.0 & 1879.0 & 1889.9 & 1897.5 & 1947.8 & 2027.6 & 2103.9 & 2181.42 & 2261.79 \\
\hline Steam Coal & 208.3 & 208.4 & 208.6 & 208.8 & 209.1 & 209.8 & 210.4 & 211.2 & 212.18 & 213.14 \\
\hline Purchased Electricity & 492.2 & 506.0 & 515.5 & 525.8 & 534.0 & 566.7 & 609.2 & 647.5 & 694.91 & 745.75 \\
\hline Total Heat and Power & 3063.4 & 3120.6 & 3154.0 & 3187.0 & 3214.0 & 3329.5 & 3491.2 & 3643.3 & 3803.31 & 3970.38 \\
\hline \multicolumn{11}{|l|}{ Feedstock } \\
\hline Liquefied Petroleum Gas & 1663.8 & 1697.8 & 1718.9 & 1740.1 & 1758.3 & 1836.9 & 1937.1 & 2019.2 & 2121.31 & 2228.60 \\
\hline Natural Gas & 732.8 & 747.8 & 757.1 & 766.4 & 774.4 & 809.0 & 853.2 & 889.3 & 934.31 & 981.57 \\
\hline Total Feedstocks & 3741.0 & 3817.3 & 3864.8 & 3912.5 & 3953.4 & 4130.1 & 4355.4 & 4540.0 & 4769.65 & 5010.88 \\
\hline Total & 6804.4 & 6937.9 & 7018.8 & 7099.6 & 7167.4 & 7459.6 & 7846.5 & 8183.3 & 8572.73 & 8980.69 \\
\hline \multicolumn{11}{|c|}{$\begin{array}{l}\text { Consumption per Unit of Output } \\
\text { (thousand Btu per } 1987 \text { dollar of output) } \\
\text { Heat and Power }\end{array}$} \\
\hline Residual Oil & 0.3 & 0.3 & 0.3 & 0.3 & 0.3 & 0.3 & 0.3 & 0.3 & 0.32 & 0.32 \\
\hline Distillate Oil & 0.0 & 0.0 & 0.0 & 0.0 & 0.0 & 0.0 & 0.0 & 0.0 & 0.03 & 0.03 \\
\hline Liquefied Petroleum Gas & 0.0 & 0.0 & 0.0 & 0.0 & 0.0 & 0.0 & 0.0 & 0.0 & 0.01 & 0.01 \\
\hline Other Petroleum & 2.9 & 2.9 & 3.0 & 3.0 & 3.0 & 3.0 & 3.0 & 3.1 & 3.07 & 3.07 \\
\hline Petroleum Subtotal & 3.3 & 3.3 & 3.3 & 3.3 & 3.4 & 3.4 & 3.4 & 3.4 & 3.43 & 3.43 \\
\hline Natural Gas 2/ & 11.5 & 11.4 & 11.3 & 11.2 & 11.2 & 10.9 & 10.7 & 10.6 & 10.44 & 10.25 \\
\hline Steam Coal & 1.3 & 1.3 & 1.3 & 1.2 & 1.2 & 1.2 & 1.1 & 1.1 & 1.02 & 0.97 \\
\hline Purchased Electricity & 3.1 & 3.1 & 3.1 & 3.1 & 3.1 & 3.2 & 3.2 & 3.3 & 3.33 & 3.38 \\
\hline Total Heat and Power & 19.1 & 19.1 & 19.0 & 19.0 & 18.9 & 18.7 & 18.5 & 18.4 & 18.20 & 17.99 \\
\hline \multicolumn{11}{|l|}{ Feedstock } \\
\hline Total Feedstocks & 23.4 & 23.3 & 23.3 & 23.3 & 23.2 & 23.1 & 23.0 & 22.9 & 22.83 & 22.71 \\
\hline Total & 42.5 & 42.4 & 42.3 & 42.2 & 42.1 & 41.8 & 41.5 & 41.4 & 41.03 & 40.70 \\
\hline Carbon Emissions (billion kilograms) & 86.8 & 88.7 & 89.9 & 91.0 & 92.0 & 95.5 & 100.9 & 105.5 & 111.11 & 116.96 \\
\hline
\end{tabular}

1/ Fuel consumption includes consumption for cogeneration.

2 / Includes petroleum coke, lubricants, and miscellaneous petroleum products.

Btu = British thermal unit.

$\mathrm{N} / \mathrm{A}=$ Not applicable.

Note: Totals may not equal sum of components due to independent rounding. The historical data used for the projections were the most available as of July 31, 1999. The numbers presented for 1998 are estimates and may differ from official EIA data reports. Also. please see EIA data publications and the Short-Term Energy Outlook for the latest estimates for 1999.

Source: Energy Information Administration, AEO2000 National Energy Modeling System run AEO2K.D100199A. 
Table 28. Glass Industry Energy Consumption

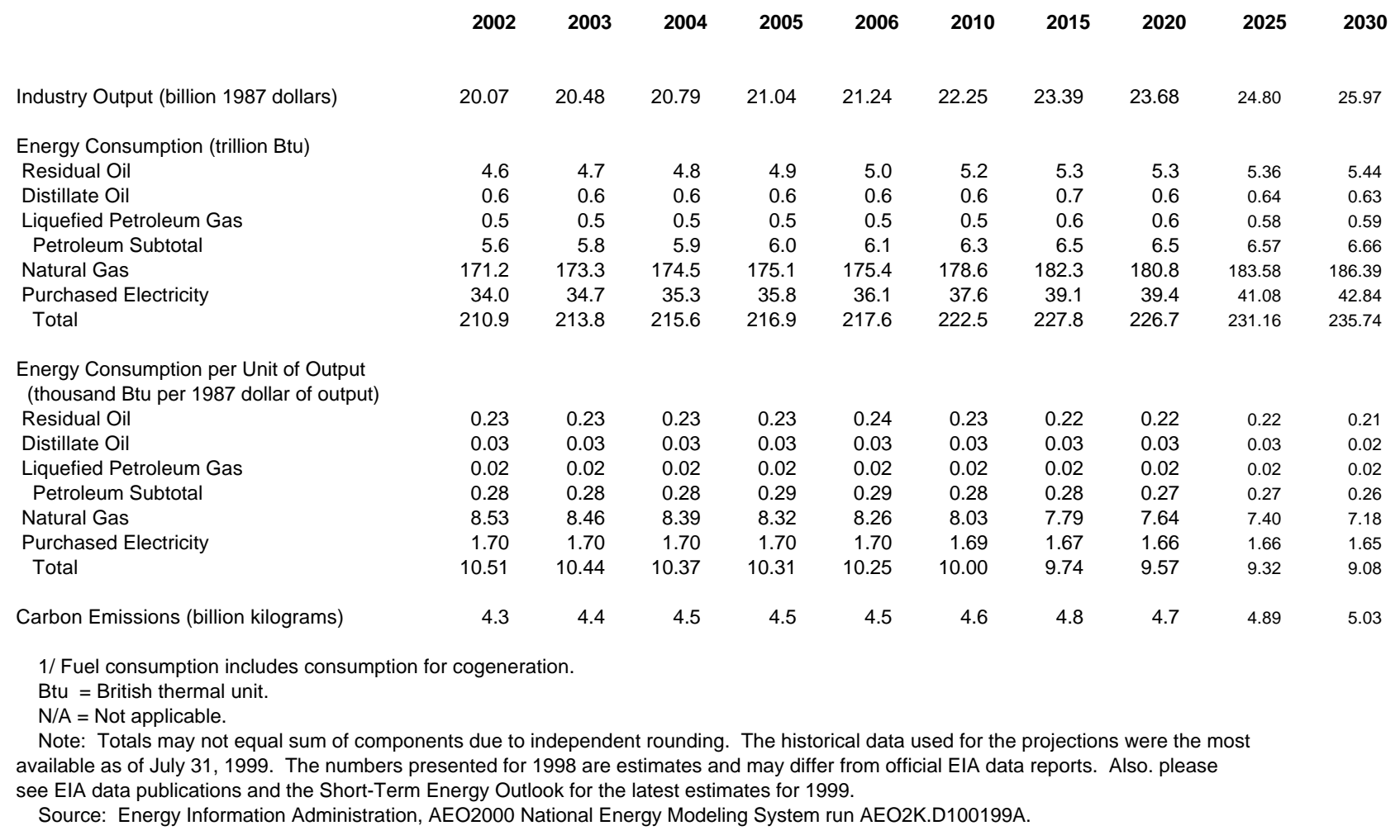


Table 29. Cement Industry Energy Consumption

\begin{tabular}{|c|c|c|c|c|c|c|c|c|c|c|}
\hline & 2002 & 2003 & 2004 & 2005 & 2006 & 2010 & 2015 & 2020 & 2025 & 2030 \\
\hline Industry Output (billion 1987 dollars) & 5.08 & 5.14 & 5.21 & 5.29 & 5.32 & 5.41 & 5.57 & 5.71 & 5.89 & 6.08 \\
\hline \multicolumn{11}{|l|}{ Energy Consumption (trillion Btu) } \\
\hline Residual Oil & 1.2 & 1.2 & 1.2 & 1.2 & 1.2 & 1.1 & 1.1 & 1.0 & 0.93 & 0.85 \\
\hline Distillate Oil & 2.6 & 2.6 & 2.6 & 2.6 & 2.5 & 2.4 & 2.3 & 2.2 & 1.96 & 1.75 \\
\hline Other Petroleum 2/ & 73.7 & 74.2 & 74.6 & 75.3 & 75.2 & 74.6 & 74.6 & 74.9 & 75.14 & 75.39 \\
\hline Natural Gas & 24.8 & 24.5 & 23.9 & 23.3 & 22.7 & 21.0 & 19.9 & 18.9 & 17.35 & 15.96 \\
\hline Steam Coal & 263.6 & 265.1 & 267.0 & 269.6 & 269.8 & 267.6 & 266.9 & 268.4 & 269.85 & 271.32 \\
\hline Purchased Electricity & 48.6 & 49.1 & 49.7 & 50.4 & 50.5 & 50.8 & 51.7 & 52.5 & 53.63 & 54.81 \\
\hline Total & 414.5 & 416.6 & 419.0 & 422.4 & 421.9 & 417.5 & 416.5 & 417.8 & 418.27 & 418.74 \\
\hline \multicolumn{11}{|c|}{$\begin{array}{l}\text { Energy Consumption per Unit of Output } \\
\text { (thousand Btu per } 1987 \text { dollar of output) }\end{array}$} \\
\hline Residual Oil & 0.24 & 0.24 & 0.23 & 0.23 & 0.22 & 0.21 & 0.19 & 0.18 & 0.16 & 0.14 \\
\hline Other Petroleum 2/ & 14.53 & 14.43 & 14.32 & 14.22 & 14.13 & 13.81 & 13.39 & 13.12 & 12.75 & 12.39 \\
\hline Petroleum Subtotal & 15.28 & 15.17 & 15.05 & 14.93 & 14.83 & 14.45 & 14.00 & 13.68 & 13.22 & 12.78 \\
\hline Natural Gas & 4.89 & 4.76 & 4.59 & 4.41 & 4.26 & 3.89 & 3.58 & 3.31 & 2.95 & 2.62 \\
\hline Steam Coal & 51.92 & 51.57 & 51.26 & 50.94 & 50.68 & 49.50 & 47.90 & 47.03 & 45.80 & 44.59 \\
\hline Purchased Electricity & 9.57 & 9.55 & 9.53 & 9.52 & 9.50 & 9.40 & 9.28 & 9.20 & 9.10 & 9.01 \\
\hline Total & 81.66 & 81.05 & 80.43 & 79.80 & 79.27 & 77.24 & 74.76 & 73.22 & 70.99 & 68.82 \\
\hline Carbon Emissions (billion kilograms) & 11.1 & 11.2 & 11.3 & 11.4 & 11.4 & 11.3 & 11.3 & 11.3 & 11.40 & 11.48 \\
\hline
\end{tabular}

1/ Fuel consumption includes consumption for cogeneration.

2/ Includes petroleum coke, lubricants, and miscellaneous petroleum products.

Btu $=$ British thermal unit.

$\mathrm{N} / \mathrm{A}=$ Not applicable.

Note: Totals may not equal sum of components due to independent rounding. The historical data used for the projections were the most available as of July 31, 1999. The numbers presented for 1998 are estimates and may differ from official EIA data reports. Also. please see EIA data publications and the Short-Term Energy Outlook for the latest estimates for 1999.

Source: Energy Information Administration, AEO2000 National Energy Modeling System run AEO2K.D100199A. 
Table 30. Iron and Steel Industries Energy Consumption

\begin{tabular}{|c|c|c|c|c|c|c|c|c|c|c|}
\hline & 2002 & 2003 & 2004 & 2005 & 2006 & 2010 & 2015 & 2020 & 2025 & 2030 \\
\hline Industry Output (billion 1987 dollars) & 69.16 & 70.94 & 72.34 & 73.39 & 73.22 & 74.54 & 76.10 & 77.03 & 79.23 & 81.49 \\
\hline \multicolumn{11}{|l|}{ Energy Consumption (trillion Btu) } \\
\hline Residual Oil & 41.5 & 42.4 & 43.1 & 43.8 & 43.6 & 42.7 & 41.5 & 41.0 & 40.14 & 39.31 \\
\hline Other Petroleum 2/ & 48.8 & 50.2 & 51.2 & 51.8 & 51.0 & 49.4 & 47.3 & 45.3 & 43.81 & 42.33 \\
\hline Petroleum Subtotal & 90.2 & 92.6 & 94.4 & 95.6 & 94.6 & 92.0 & 88.9 & 86.3 & 83.94 & 81.62 \\
\hline Metallurgical Coal & 741.3 & 728.3 & 715.6 & 703.1 & 690.8 & 643.6 & 589.0 & 540.4 & 495.02 & 453.44 \\
\hline Net Coke Imports & 124.0 & 141.3 & 156.4 & 169.2 & 174.0 & 205.3 & 241.7 & 273.2 & 351.81 & 452.99 \\
\hline Steam Coal & 86.2 & 87.1 & 88.2 & 89.3 & 89.4 & 90.4 & 91.3 & 92.6 & 94.85 & 97.14 \\
\hline Coal Subtotal & 951.5 & 956.8 & 960.2 & 961.6 & 954.2 & 939.3 & 921.9 & 906.3 & 892.72 & 879.40 \\
\hline Purchased Electricity & 165.8 & 171.4 & 176.1 & 180.1 & 179.9 & 184.7 & 190.2 & 195.0 & 203.56 & 212.46 \\
\hline Total & 1696.8 & 1715.4 & 1728.5 & 1735.7 & 1722.4 & 1705.3 & 1688.9 & 1674.4 & 1663.61 & 1652.91 \\
\hline \multicolumn{11}{|l|}{$\begin{array}{l}\text { Energy Consumption per Unit of Output } \\
\text { (thousand Btu per } 1987 \text { dollar of output) }\end{array}$} \\
\hline Residual Oil & 0.60 & 0.60 & 0.60 & 0.60 & 0.60 & 0.57 & 0.55 & 0.53 & 0.51 & 0.48 \\
\hline Other Petroleum 2/ & 0.71 & 0.71 & 0.71 & 0.71 & 0.70 & 0.66 & 0.62 & 0.59 & 0.55 & 0.52 \\
\hline Petroleum Subtotal & 1.30 & 1.30 & 1.30 & 1.30 & 1.29 & 1.23 & 1.17 & 1.12 & 1.06 & 1.00 \\
\hline Natural Gas & 7.07 & 6.97 & 6.88 & 6.79 & 6.74 & 6.56 & 6.41 & 6.32 & 6.12 & 5.93 \\
\hline Metallurgical Coal & 10.72 & 10.27 & 9.89 & 9.58 & 9.44 & 8.63 & 7.74 & 7.02 & 6.25 & 5.56 \\
\hline Net Coke Imports & 1.79 & 1.99 & 2.16 & 2.31 & 2.38 & 2.75 & 3.18 & 3.55 & 4.44 & 5.56 \\
\hline Steam Coal & 1.25 & 1.23 & 1.22 & 1.22 & 1.22 & 1.21 & 1.20 & 1.20 & 1.20 & 1.19 \\
\hline Coal Subtotal & 13.76 & 13.49 & 13.27 & 13.10 & 13.03 & 12.60 & 12.11 & 11.76 & 11.27 & 10.79 \\
\hline Purchased Electricity & 2.40 & 2.42 & 2.43 & 2.45 & 2.46 & 2.48 & 2.50 & 2.53 & 2.57 & 2.61 \\
\hline Total & 24.53 & 24.18 & 23.89 & 23.65 & 23.52 & 22.88 & 22.19 & 21.74 & 21.00 & 20.28 \\
\hline Carbon Emissions (billion kilograms) & 41.5 & 42.1 & 42.6 & 42.8 & 42.5 & 42.1 & 41.9 & 41.7 & 41.69 & 41.69 \\
\hline
\end{tabular}

1/ Fuel consumption includes consumption for cogeneration.

2/ Includes petroleum coke, lubricants, and miscellaneous petroleum products.

$\mathrm{Btu}=$ British thermal unit.

$\mathrm{N} / \mathrm{A}=$ Not applicable.

Note: Totals may not equal sum of components due to independent rounding. The historical data used for the projections were the most available as of July 31, 1999. The numbers presented for 1998 are estimates and may differ from official EIA data reports. Also. please see EIA data publications and the Short-Term Energy Outlook for the latest estimates for 1999.

Source: Energy Information Administration, AEO2000 National Energy Modeling System run AEO2K.D100199A. 
Table 31. Aluminum Industry Energy Consumption

\begin{tabular}{|c|c|c|c|c|c|c|c|c|c|c|}
\hline & 2002 & 2003 & 2004 & 2005 & 2006 & 2010 & 2015 & 2020 & 2025 & 2030 \\
\hline Industry Output (billion 1987 dollars) & 30.78 & 30.92 & 31.26 & 31.55 & 31.64 & 32.00 & 32.82 & 33.34 & 34.11 & 34.91 \\
\hline \multicolumn{11}{|l|}{ Energy Consumption (trillion Btu) } \\
\hline Distillate Oil & 0.1 & 0.1 & 0.1 & 0.1 & 0.1 & 0.1 & 0.1 & 0.1 & 0.14 & 0.14 \\
\hline Liquefied Petroleum Gas & 0.0 & 0.0 & 0.0 & 0.0 & 0.0 & 0.0 & 0.0 & 0.0 & 0.01 & 0.01 \\
\hline Petroleum Coke & 14.2 & 14.2 & 14.2 & 14.3 & 14.3 & 14.2 & 14.3 & 14.4 & 14.48 & 14.53 \\
\hline Petroleun Subtotal & 45.2 & 45.2 & 45.5 & 45.7 & 45.6 & 45.4 & 45.6 & 45.8 & 45.96 & 46.11 \\
\hline Natural Gas & 82.3 & 82.3 & 82.6 & 82.9 & 82.7 & 81.9 & 82.3 & 82.6 & 82.68 & 82.72 \\
\hline Purchased Electricity & 217.1 & 217.5 & 219.4 & 220.8 & 220.8 & 221.2 & 224.6 & 226.8 & 229.40 & 232.02 \\
\hline Total & 344.7 & 345.0 & 347.5 & 349.3 & 349.1 & 348.5 & 352.5 & 355.3 & 358.01 & 360.80 \\
\hline \multicolumn{11}{|c|}{$\begin{array}{l}\text { Energy Consumption per Unit of Output } \\
\text { (thousand Btu per } 1987 \text { dollar of output) }\end{array}$} \\
\hline Distillate Oil & 0.00 & 0.00 & 0.00 & 0.00 & 0.00 & 0.00 & 0.00 & 0.00 & 0.00 & 0.00 \\
\hline Petroleum Coke & 0.46 & 0.46 & 0.46 & 0.45 & 0.45 & 0.44 & 0.44 & 0.43 & 0.42 & 0.42 \\
\hline Other Petroleum & 1.00 & 1.00 & 1.00 & 0.99 & 0.99 & 0.97 & 0.95 & 0.94 & 0.92 & 0.90 \\
\hline Petroleun Subtotal & 1.47 & 1.46 & 1.46 & 1.45 & 1.44 & 1.42 & 1.39 & 1.37 & 1.35 & 1.32 \\
\hline Natural Gas & 2.67 & 2.66 & 2.64 & 2.63 & 2.61 & 2.56 & 2.51 & 2.48 & 2.42 & 2.37 \\
\hline Purchased Electricity & 7.05 & 7.04 & 7.02 & 7.00 & 6.98 & 6.91 & 6.84 & 6.80 & 6.72 & 6.65 \\
\hline Total & 11.20 & 11.16 & 11.11 & 11.07 & 11.03 & 10.89 & 10.74 & 10.66 & 10.49 & 10.34 \\
\hline Carbon Emissions (billion kilograms) & 13.2 & 13.3 & 13.4 & 13.5 & 13.5 & 13.3 & 13.5 & 13.6 & 13.80 & 14.01 \\
\hline
\end{tabular}

1/ Fuel consumption includes consumption for cogeneration.

$\mathrm{Btu}=$ British thermal unit.

$\mathrm{N} / \mathrm{A}=$ Not applicable.

Note: Totals may not equal sum of components due to independent rounding. The historical data used for the projections were the most available as of July 31, 1999. The numbers presented for 1998 are estimates and may differ from official EIA data reports. Also. please see EIA data publications and the Short-Term Energy Outlook for the latest estimates for 1999.

Source: Energy Information Administration, AEO2000 National Energy Modeling System run AEO2K.D100199A. 
Table 32. Other Industrial Sector Energy Consumption (Trillion Btu)

\begin{tabular}{|c|c|c|c|c|c|c|c|c|c|c|}
\hline & 2002 & 2003 & 2004 & 2005 & 2006 & 2010 & 2015 & 2020 & 2025 & 2030 \\
\hline \multicolumn{11}{|l|}{ Agriculture } \\
\hline Distillate Oil & 594.2 & 601.3 & 609.6 & 617.5 & 624.1 & 652.4 & 695.8 & 736.3 & 782.34 & 831.21 \\
\hline Liquid Petroleum Gas & 82.0 & 83.0 & 84.1 & 85.2 & 86.1 & 90.1 & 96.1 & 101.7 & 108.02 & 114.77 \\
\hline Motor Gasoline & 97.3 & 98.5 & 99.9 & 101.2 & 102.3 & 106.9 & 114.0 & 120.7 & 128.20 & 136.21 \\
\hline Other Petroleum & 17.3 & 17.5 & 17.8 & 18.0 & 18.2 & 19.0 & 20.3 & 21.4 & 22.77 & 24.19 \\
\hline Petroleum Subtotal & 790.8 & 800.3 & 811.4 & 821.9 & 830.7 & 868.3 & 926.2 & 980.1 & 1041.32 & 1106.38 \\
\hline Natural Gas & 51.5 & 52.1 & 52.9 & 53.6 & 54.1 & 56.6 & 60.4 & 64.0 & 68.04 & 72.34 \\
\hline Steam Coal & 0.5 & 0.5 & 0.5 & 0.5 & 0.5 & 0.5 & 0.5 & 0.5 & 0.53 & 0.55 \\
\hline Renewables & 20.5 & 20.7 & 21.0 & 21.3 & 21.6 & 22.6 & 24.1 & 25.5 & 27.14 & 28.88 \\
\hline Purchased Electricity & 141.7 & 143.4 & 145.4 & 147.3 & 148.8 & 155.5 & 165.9 & 175.5 & 186.44 & 198.06 \\
\hline Total & 1005.0 & 1017.1 & 1031.1 & 1044.6 & 1055.7 & 1103.5 & 1177.1 & 1245.6 & 1323.48 & 1406.20 \\
\hline Industry Output (billion 1987 dollars) & 270.80 & 273.83 & 277.27 & 280.58 & 283.30 & 294.55 & 312.61 & 329.73 & 348.51 & 368.36 \\
\hline Energy Consumption per Unit of & & & & & & & & & & \\
\hline Output (thousand Btu per 1987 dollar of outp। & 3.71 & 3.71 & 3.72 & 3.72 & 3.73 & 3.75 & 3.77 & 3.78 & 3.80 & 3.82 \\
\hline Carbon Emissions (billion kilograms) & 23.4 & 23.7 & 24.1 & 24.4 & 24.6 & 25.6 & 27.4 & 28.9 & 30.78 & 32.76 \\
\hline \multicolumn{11}{|l|}{ Construction } \\
\hline Distillate Oil & 205.7 & 209.7 & 215.5 & 221.2 & 225.1 & 235.7 & 256.9 & 273.8 & 296.89 & 321.89 \\
\hline Motor Gasoline & 126.5 & 129.0 & 132.5 & 136.0 & 138.4 & 145.0 & 158.0 & 168.4 & 182.61 & 197.99 \\
\hline Asphalt and Road Oil & 1403.3 & 1429.8 & 1468.5 & 1507.0 & 1533.8 & 1607.9 & 1753.3 & 1873.3 & 2030.58 & 2201.02 \\
\hline Petroleum Subtotal & 1735.5 & 1768.6 & 1816.5 & 1864.2 & 1897.3 & 1988.6 & 2168.2 & 2315.6 & 2510.08 & 2720.90 \\
\hline Natural Gas & 205.3 & 209.2 & 215.0 & 220.7 & 224.6 & 235.2 & 256.3 & 273.2 & 296.19 & 321.13 \\
\hline Steam Coal & 154.4 & 157.4 & 161.7 & 166.0 & 169.0 & 176.9 & 192.8 & 205.5 & 222.84 & 241.61 \\
\hline Purchased Electricity & 133.5 & 136.1 & 139.9 & 143.6 & 146.1 & 153.0 & 166.7 & 177.7 & 192.66 & 208.87 \\
\hline Total & 2228.7 & 2271.3 & 2333.0 & 2394.5 & 2436.9 & 2553.7 & 2784.1 & 2972.0 & 3221.77 & 3492.51 \\
\hline Industry Output (billion 1987 dollars) & 473.27 & 483.01 & 496.95 & 510.78 & 520.31 & 546.37 & 597.73 & 638.86 & 695.54 & 757.24 \\
\hline Energy Consumption per Unit of & & & & & & & & & & \\
\hline Output (thousand Btu per 1987 dollar of outp। & 4.71 & 4.70 & 4.69 & 4.69 & 4.68 & 4.67 & 4.66 & 4.65 & 4.63 & 4.61 \\
\hline Carbon Emissions (billion kilograms) & 20.2 & 20.7 & 21.3 & 21.8 & 22.2 & 23.1 & 25.2 & 26.8 & 29.17 & 31.68 \\
\hline \multicolumn{11}{|l|}{ Mining } \\
\hline Residual Oil & 25.8 & 26.2 & 26.5 & 26.8 & 27.0 & 27.7 & 28.6 & 29.3 & 30.27 & 31.29 \\
\hline Distillate Oil & 177.4 & 180.4 & 182.8 & 184.7 & 186.2 & 190.5 & 197.2 & 201.9 & 208.70 & 215.74 \\
\hline asoline & 14.0 & 14.1 & 14.2 & 14.3 & 14.5 & 15.1 & 16.0 & 16.6 & 17.15 & 17.74 \\
\hline Other Petroleum & 7.5 & 7.5 & 7.5 & 7.6 & 7.8 & 8.2 & 8.8 & 9.2 & 9.49 & 9.83 \\
\hline Petroleum Subtotal & 224.6 & 228.2 & 231.0 & 233.5 & 235.5 & 241.5 & 250.6 & 256.9 & 265.61 & 274.61 \\
\hline Natural Gas & 340.4 & 342.0 & 343.0 & 347.4 & 352.6 & 372.2 & 399.6 & 414.8 & 429.13 & 443.93 \\
\hline Lease and Plant Fuel & 1253.40 & 1267.77 & 1275.82 & 1298.77 & 1332.72 & 1466.72 & 1613.93 & 1712.70 & 1831.36 & 1958.24 \\
\hline Steam Coal & 96.9 & 98.7 & 100.0 & 101.0 & 101.6 & 103.1 & 105.1 & 106.1 & 109.27 & 112.53 \\
\hline Rene & 1.1 & 1.1 & 1.1 & 1.1 & 1.1 & 1.2 & 1.3 & 1.3 & 1.35 & 1.40 \\
\hline Purchased Electricity & 293.2 & 297.5 & 300.8 & 304.5 & 307.6 & 317.9 & 332.7 & 341.5 & 353.54 & 365.99 \\
\hline Total & 2209.6 & 2235.1 & 2251.6 & 2286.2 & 2331.1 & 2502.6 & 2703.2 & 2833.4 & 2988.08 & 3151.26 \\
\hline Industry Output (billion 1987 dollars) & 135.81 & 137.50 & 138.83 & 140.57 & 142.29 & 148.13 & 156.59 & 161.91 & 168.14 & 174.60 \\
\hline Energy Consumption pe & & & & & & & & & & \\
\hline Output (thousand Btu per 1987 dollar of outp। & 16.27 & 16.26 & 16.22 & 16.26 & 16.38 & 16.89 & 17.26 & 17.50 & 17.77 & 18.05 \\
\hline Carbon Emissions (billion kilograms) & 27.0 & 27.4 & 27.7 & 28.0 & 28.3 & 29.0 & 30.4 & 31.2 & 32.39 & 33.61 \\
\hline \multicolumn{11}{|l|}{ Metal-Based Durables Co } \\
\hline Residual Oil & 33.0 & 34.9 & 36.4 & 38.1 & 39.7 & 45.6 & 52.8 & 58.2 & 67.50 & 78.32 \\
\hline Distillate Oil & 22.1 & 23.4 & 24.4 & 25.5 & 26.6 & 30.2 & 34.7 & 38.4 & 43.72 & 49.83 \\
\hline Liquid & 4.2 & 4.5 & 4.7 & 4.9 & 5.2 & 5.8 & 6.7 & 7.3 & 8.30 & 9.40 \\
\hline Other Petroleum & 0.0 & 0.0 & 0.0 & 0.0 & 0.0 & 0.0 & 0.0 & 0.0 & 0.0 & 0.0 \\
\hline Petroleum Subtotal & 59.4 & 62.8 & 65.4 & 68.6 & 71.4 & 81.6 & 94.2 & 103.8 & 119.48 & 137.47 \\
\hline Natural Gas & 859.3 & 899.2 & 925.8 & 954.5 & 979.3 & 1087.8 & 1232.2 & 1348.5 & 1526.34 & 1727.62 \\
\hline Steam Coal & 83.3 & 83.4 & 83.4 & 83.5 & 83.6 & 83.9 & 84.3 & 84.6 & 85.01 & 85.38 \\
\hline Renewables & 1.0 & 1.0 & 1.1 & 1.1 & 1.1 & 1.2 & 1.4 & 1.5 & 1.69 & 1.90 \\
\hline Purchased Electricity & 667.4 & 698.9 & 721.2 & 746.0 & 766.5 & 852.8 & 965.6 & 1061.2 & 1205.78 & 1370.07 \\
\hline Total & 1670.4 & 1745.4 & 1796.9 & 1853.7 & 1902.0 & 2107.3 & 2377.5 & 2599.7 & 2933.97 & 3311.22 \\
\hline $\begin{array}{l}\text { Industry Output (billion } 1987 \text { dollars) } \\
\text { Energy Consumption per Unit of }\end{array}$ & 1637.83 & 1720.99 & 1779.92 & 184 & 1900.41 & 2140.73 & 2460.26 & 2732.99 & 3149.87 & 3630.34 \\
\hline Output (thousand Btu per 1987 dollar & 1.02 & 1.01 & 1.01 & 1.01 & 1.00 & 0.98 & 0.97 & 0.95 & 0.93 & 0.91 \\
\hline
\end{tabular}


Table 32. Other Industrial Sector Energy Consumption (Trillion Btu)

\begin{tabular}{|c|c|c|c|c|c|c|c|c|c|c|}
\hline & 2002 & 2003 & 2004 & 2005 & 2006 & 2010 & 2015 & 2020 & 2025 & 2030 \\
\hline Carbon Emissions (billion kilograms) & 50.1 & 52.6 & 54.3 & 56.0 & 57.4 & 63.0 & 71.2 & 77.9 & 88.37 & 100.29 \\
\hline \multicolumn{11}{|l|}{ Other Manufacturing Consumption } \\
\hline Residual Oil & 44.3 & 45.2 & 46.1 & 47.1 & 47.9 & 50.1 & 52.9 & 55.3 & 57.50 & 59.76 \\
\hline Distillate Oil & 51.0 & 52.3 & 53.7 & 55.2 & 56.3 & 59.0 & 63.2 & 66.4 & 68.66 & 71.04 \\
\hline Liquid Petroleum Gas & 16.3 & 16.7 & 17.1 & 17.7 & 18.2 & 19.2 & 20.6 & 21.7 & 23.12 & 24.60 \\
\hline Petroleum Subtotal & 111.6 & 114.2 & 116.9 & 120.0 & 122.5 & 128.3 & 136.7 & 143.4 & 149.24 & 155.32 \\
\hline Steam Coal & 157.6 & 159.2 & 160.3 & 161.3 & 161.7 & 164.0 & 168.0 & 171.0 & 174.92 & 178.89 \\
\hline Renewables & 318.7 & 325.3 & 330.4 & 335.5 & 338.2 & 352.4 & 376.5 & 397.6 & 422.69 & 449.32 \\
\hline Purchased Electricity & 779.5 & 794.9 & 807.3 & 820.3 & 826.7 & 858.4 & 911.9 & 959.5 & 1015.93 & 1075.64 \\
\hline Total & 3105.6 & 3162.9 & 3206.8 & 3249.3 & 3270.2 & 3383.3 & 3580.9 & 3750.7 & 3947.98 & 4155.64 \\
\hline Industry Output (billion 1987 dollars) & 909.72 & 927.81 & 941.95 & 955.82 & 963.16 & 1001.73 & 1067.03 & 1124.40 & 1191.51 & 1262.63 \\
\hline $\begin{array}{l}\text { Energy Consumption per Unit of Output } \\
\text { (thousand Btu per } 1987 \text { dollar of output) }\end{array}$ & 3.41 & 3.41 & 3.40 & 3.40 & 3.40 & 3.38 & 3.36 & 3.34 & 3.31 & 3.29 \\
\hline
\end{tabular}

Note: Totals may not equal sum of components due to independent rounding. The historical data used for the projections were the most available as of July 31, 1999. The numbers presented for 1998 are estimates and may differ from official EIA data reports. Also. please see EIA data publications and the Short-Term Energy Outlook for the latest estimates for 1999.

Source: Energy Information Administration, AEO2000 National Energy Modeling System run AEO2K.D100199A. 
Table 33. Transportation Sector Energy Use by Mode and Type (Trillion Btu)

$\begin{array}{llllllllll}2002 & 2003 & 2004 & 2005 & 2006 & 2010 & 2015 & 2020 & 2025 & 2030\end{array}$

Energy Use by Mode

Highway

Light-Duty Vehicles

Automobiles

Light Trucks

Motorcycles

Commercial Light Trucks 1/

Buses

Transit

Intercity

School

Freight Trucks 2/

Medium (1000-26000 pounds)

Large ( $>26000$ pounds)

Non-Highway

Air $3 /$

General Aviation

Domestic Air Carriers

International Air Carriers

Freight Carriers

Water 4/

Freight

Domestic Shipping

International Shipping

Recreational Boats

Freight

Passenger

Intercity

Transit

Commuter

Lubricants

Pipeline Fuel Natural Gas

Military Use

Aviation

Residual Fuel Use

Distillate Fuel Use

Total

$\begin{array}{rrrrrrrrrr}16010.2 & 16278.9 & 16640.7 & 16966.2 & 17302.8 & 18536.6 & 19867.1 & 21027.1 & 22830.29 & 24788.06 \\ 7706.6 & 7615.2 & 7573.3 & 7516.1 & 7473.4 & 7336.1 & 7275.9 & 7393.9 & 7273.50 & 7155.00 \\ 8282.4 & 8641.2 & 9045.1 & 9428.6 & 9811.7 & 11181.0 & 12570.1 & 13611.3 & 16006.87 & 18824.02 \\ 22.1 & 21.9 & 21.8 & 21.6 & 21.5 & 21.1 & 20.9 & 21.2 & 20.88 & 20.54 \\ 642.3 & 652.3 & 662.8 & 673.1 & 681.6 & 714.0 & 757.4 & 793.2 & 841.13 & 891.93 \\ 153.2 & 153.5 & 154.1 & 154.4 & 154.7 & 155.1 & 153.9 & 152.0 & 152.15 & 152.26 \\ 73.8 & 73.9 & 74.2 & 74.4 & 74.5 & 74.7 & 74.1 & 73.2 & 73.27 & 73.33 \\ 20.0 & 20.1 & 20.2 & 20.2 & 20.2 & 20.3 & 20.1 & 19.9 & 19.91 & 19.92 \\ 59.4 & 59.5 & 59.7 & 59.9 & 60.0 & 60.1 & 59.7 & 58.9 & 58.97 & 59.01 \\ 4414.2 & 4493.8 & 4562.5 & 4627.5 & 4668.0 & 4789.9 & 4939.7 & 5025.9 & 5252.36 & 5489.03 \\ 810.1 & 808.4 & 803.5 & 800.5 & 799.2 & 806.8 & 834.9 & 866.4 & 868.71 & 870.98 \\ 360.0 & 3685.4 & 3759.0 & 3827.0 & 3868.8 & 3983.1 & 4104.8 & 4159.4 & 4389.14 & 4631.53\end{array}$

$\begin{array}{rrrrrrrrrr}3604.0 & 3685.4 & 3759.0 & 3827.0 & 3868.8 & 3983.1 & 4104.8 & 4159.4 & 4389.14 & 4631.53\end{array}$

$\begin{array}{rrrrrrrrrr}3520.1 & 3662.6 & 3812.9 & 3946.9 & 4100.9 & 4656.6 & 5386.1 & 6124.8 & 7155.06 & 8358.65 \\ 200.1 & 206.5 & 213.3 & 219.3 & 226.3 & 251.4 & 284.4 & 317.9 & 361.33 & 410.69 \\ 1929.4 & 2000.1 & 2052.4 & 2101.4 & 2143.5 & 2311.4 & 2533.8 & 2762.2 & 3060.05 & 3389.97 \\ 855.5 & 876.2 & 919.5 & 943.2 & 996.9 & 1125.9 & 1294.3 & 1466.4 & 1719.05 & 2015.19 \\ 535.1 & 579.7 & 627.7 & 682.9 & 734.2 & 967.9 & 1273.5 & 1578.2 & 2131.97 & 2880.01 \\ 1247.2 & 1274.4 & 1304.4 & 1336.5 & 1366.5 & 1490.9 & 1646.2 & 1796.5 & 1983.78 & 2190.55 \\ 989.2 & 1014.4 & 1042.1 & 1072.1 & 1100.0 & 1216.3 & 1361.4 & 1501.6 & 1682.45 & 1885.05 \\ 278.5 & 279.0 & 278.8 & 279.3 & 279.1 & 277.1 & 276.3 & 270.8 & 267.94 & 265.10 \\ 710.7 & 735.4 & 763.2 & 792.8 & 820.9 & 939.2 & 1085.1 & 1230.8 & 1434.87 & 1672.77 \\ 258.1 & 260.0 & 262.3 & 264.4 & 266.5 & 274.6 & 284.9 & 294.9 & 305.95 & 317.40 \\ 581.3 & 585.0 & 591.2 & 595.0 & 601.0 & 609.2 & 623.7 & 636.8 & 656.09 & 676.02 \\ 471.4 & 473.1 & 477.2 & 479.1 & 483.2 & 483.5 & 488.2 & 491.0 & 499.24 & 507.64 \\ 109.9 & 112.0 & 114.0 & 115.9 & 117.8 & 125.7 & 135.6 & 145.8 & 158.11 & 171.48 \\ 20.9 & 21.2 & 21.6 & 22.0 & 22.3 & 23.8 & 25.7 & 27.7 & 30.00 & 32.55 \\ 47.9 & 48.8 & 49.7 & 50.5 & 51.3 & 54.8 & 59.1 & 63.5 & 68.86 & 74.67 \\ 41.2 & 41.9 & 42.7 & 43.4 & 44.1 & 47.1 & 50.8 & 54.6 & 59.24 & 64.27 \\ 273.1 & 275.0 & 278.2 & 282.9 & 287.0 & 297.7 & 313.7 & 325.9 & 343.50 & 362.03 \\ 745.8 & 751.9 & 754.4 & 767.8 & 788.9 & 866.4 & 948.1 & 987.9 & 1051.32 & 1118.77 \\ & & & & & & & & & \\ 521.6 & 518.3 & 516.7 & 520.0 & 525.4 & 542.2 & 548.9 & 556.9 & 565.33 & 573.89 \\ 454.7 & 451.8 & 450.4 & 453.3 & 458.0 & 472.7 & 478.5 & 485.5 & 492.65 & 499.95 \\ 8.1 & 8.0 & 8.0 & 8.1 & 8.2 & 8.4 & 8.5 & 8.6 & 8.86 & 9.08 \\ 58.8 & 58.4 & 58.3 & 58.6 & 59.2 & 61.1 & 61.9 & 62.8 & 63.82 & 64.86\end{array}$

Energy Use by Type

Motor Gasoline

Distillate (diesel)

Jet Fuel (kerosene \& naptha)

Residual Oil

Aviation Gasoline

Liquid Petroleum Gas

Lubricants

Oil Subtota

Methanol

Ethanol

Electricity

Compressed Natural Gas

Liquid Hydrogen

Pipeline Fuel Natural Gas

Total Consumption

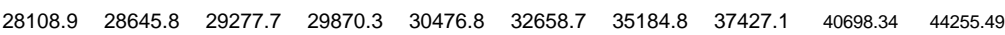

$\begin{array}{rrrrrrrrrr}16817.6 & 17043.8 & 17369.0 & 17654.3 & 17958.5 & 19059.5 & 20208.7 & 21231.9 & 22776.22 & 24432.89 \\ 5273.7 & 5364.5 & 5448.6 & 5530.2 & 5582.6 & 5757.3 & 6023.0 & 6224.0 & 6557.70 & 6909.34 \\ 3766.4 & 3899.2 & 4041.0 & 4171.5 & 4322.9 & 4866.9 & 5567.4 & 6277.8 & 7237.59 & 8344.10 \\ 725.7 & 747.8 & 772.5 & 799.0 & 824.1 & 929.2 & 1059.0 & 1187.3 & 1361.54 & 1561.33 \\ 42.4 & 42.3 & 42.3 & 42.3 & 42.2 & 42.1 & 42.1 & 42.1 & 41.92 & 41.76 \\ 68.5 & 74.8 & 80.8 & 86.3 & 91.1 & 106.9 & 123.0 & 132.8 & 169.79 & 217.07 \\ 273.1 & 275.0 & 278.2 & 282.9 & 287.0 & 297.7 & 313.7 & 325.9 & 343.50 & 362.03 \\ 26967.3 & 27447.5 & 28032.5 & 28566.5 & 29108.4 & 31059.6 & 33336.9 & 35421.8 & 38379.96 & 41585.22 \\ 40.1 & 50.7 & 55.1 & 63.3 & 72.1 & 101.0 & 132.0 & 152.0 & 296.26 & 577.62 \\ 17.4 & 22.0 & 27.2 & 32.4 & 37.7 & 57.1 & 73.7 & 79.4 & 169.05 & 360.00 \\ 74.2 & 81.7 & 89.0 & 95.7 & 101.8 & 124.0 & 149.5 & 168.1 & 206.68 & 254.12 \\ 98.1 & 119.2 & 139.6 & 158.1 & 174.2 & 230.4 & 289.5 & 327.6 & 604.42 & 1115.08 \\ 0.0 & 0.0 & 0.0 & 0.0 & 0.0 & 0.0 & 0.0 & 0.0 & 0.0 & 0.0 \\ 745.8 & 751.9 & 754.4 & 767.8 & 788.9 & 866.4 & 948.1 & 987.9 & 1051.32 & 1118.77 \\ & & & & & & & & & \\ 27942.9 & 28473.0 & 29097.8 & 29683.9 & 30283.1 & 32438.4 & 34929.7 & 37136.8 & 40362.86 & 43869.22\end{array}$

1/ Commercial light trucks from 8,500 to 10,000 pounds.

2/ Does not include commercial bus and military use.

$3 /$ Does not include military jet fuel use.

4/ Does not include military residual oil.

Btu $=$ British thermal unit.

Note: Totals may not equal sum of components due to independent rounding. The historical data used for the projections were the most

available as of July 31, 1999. The numbers presented for 1998 are estimates and may differ from official ElA data reports. Also. please

see EIA data publications and the Short-Term Energy Outlook for the latest estimates for 1999.

Sources: 1998 values derived using: Energy Infornation Administration (EIA), Short-Term Energy Outlook, September 1999,

Online. http:/www.eia.doe.gov/pub/forecasting/steo/oldsteos/sep99.html (October 12, 1999); EIA, Fuel Oil and Kerosene Sales

1997, DOE/EIA-0535(97) (Washington, D.C., August 1998); EIA, State Energy Data Report 1996, DOE/EIA-0214(96)

(Washington, DC, Febuary 1999); Oak Ridge National Laboratory, Transportation Energy Book: 17 and 18 (September 1998);

Department of Defense, Defense Fuel Supply Center; and EIA, AEO2000 National Energy Modeling System run

AEO2K.D100199A. Projections: EIA, AEO2000 National Energy Modeling System run AEO2K.D100199A. 
Table 34. Transportation Sector Energy Use by Fuel Type Within a Mode

(Trillion Btu per Year)

\begin{tabular}{|c|c|c|c|c|c|c|c|c|c|c|}
\hline & 2002 & 2003 & 2004 & 2005 & 2006 & 2010 & 2015 & 2020 & 2025 & 2030 \\
\hline \multicolumn{11}{|l|}{ Light-Duty Vehicle } \\
\hline Motor Gasoline & 15646.60 & 15877.02 & 16203.42 & 16488.80 & 16793.74 & 17890.77 & 19016.85 & 20013.15 & 21578.62 & 23266.55 \\
\hline Methanol & 40.09 & 50.67 & 55.12 & 63.29 & 72.07 & 100.96 & 131.99 & 151.95 & 296.26 & 577.62 \\
\hline Ethanol & 17.44 & 21.98 & 27.15 & 32.42 & 37.73 & 57.10 & 73.67 & 79.38 & 169.05 & 360.00 \\
\hline Compressed Natural Gas & 94.36 & 114.28 & 133.15 & 149.69 & 163.39 & 206.87 & 249.62 & 277.50 & 506.31 & 923.76 \\
\hline Liquid Petroleum Gas & 49.69 & 56.03 & 62.13 & 67.49 & 71.98 & 86.44 & 100.63 & 109.31 & 153.63 & 215.93 \\
\hline Electricity & 1.77 & 7.97 & 13.91 & 19.35 & 24.18 & 41.13 & 60.19 & 72.04 & 228.90 & 727.24 \\
\hline Liquid Hydrogen & 0.00 & 0.00 & 0.00 & 0.00 & 0.00 & 0.00 & 0.00 & 0.00 & 0.00 & 0.00 \\
\hline Distillate (diesel) & 160.20 & 150.93 & 145.78 & 145.12 & 139.70 & 153.39 & 234.17 & 323.81 & 354.58 & 388.27 \\
\hline Total & 16010.15 & 16278.89 & 16640.66 & 16966.16 & 17302.79 & 18536.65 & 19867.11 & 21027.15 & 22830.29 & 24788.06 \\
\hline Commercial Light Trucks Gasoline 1/ & 642.33 & 652.28 & 662.80 & 673.12 & 681.61 & 714.04 & 757.35 & 793.22 & 841.13 & 891.93 \\
\hline \multicolumn{11}{|l|}{ Freight Trucks 2/ } \\
\hline Motor Gasoline & 263.25 & 247.16 & 233.14 & 220.54 & 209.23 & 172.69 & 142.30 & 123.32 & 97.30 & 76.77 \\
\hline Distillate (diesel) & 4128.42 & 4223.02 & 4304.24 & 4379.73 & 4428.92 & 4573.18 & 4735.09 & 4828.95 & 5109.37 & 5406.08 \\
\hline Compressed Natural Gas & 3.71 & 4.89 & 6.46 & 8.45 & 10.83 & 23.58 & 39.93 & 50.12 & 99.54 & 197.70 \\
\hline Liquid Petroleum Gas & 18.79 & 18.77 & 18.66 & 18.80 & 19.08 & 20.45 & 22.33 & 23.49 & 24.20 & 24.93 \\
\hline Total & 4414.16 & 4493.84 & 4562.49 & 4627.51 & 4668.05 & 4789.90 & 4939.66 & 5025.89 & 5252.36 & 5489.03 \\
\hline \multicolumn{11}{|l|}{ Freight Rail 3/ } \\
\hline Distillate (diesel) & 471.36 & 473.06 & 477.25 & 479.10 & 483.22 & 483.54 & 488.17 & 490.98 & 499.24 & 507.64 \\
\hline Total & 471.36 & 473.06 & 477.25 & 479.10 & 483.22 & 483.54 & 488.17 & 490.98 & 499.24 & 507.64 \\
\hline \multicolumn{11}{|l|}{ Domestic Shipping } \\
\hline Distillate (diesel) & 194.15 & 194.54 & 194.39 & 194.69 & 194.58 & 193.18 & 192.64 & 188.81 & 186.36 & 183.94 \\
\hline Residual Oil & 84.32 & 84.49 & 84.43 & 84.56 & 84.51 & 83.90 & 83.67 & 82.00 & 81.59 & 81.18 \\
\hline Motor Gasoline & 0.00 & 0.00 & 0.00 & 0.00 & 0.00 & 0.00 & 0.00 & 0.00 & 0.00 & 0.00 \\
\hline Total & 278.47 & 279.03 & 278.82 & 279.25 & 279.09 & 277.09 & 276.30 & 270.82 & 267.94 & 265.10 \\
\hline \multicolumn{11}{|l|}{ International Shipping } \\
\hline Distillate (diesel) & 77.47 & 80.16 & 83.19 & 86.42 & 89.48 & 102.37 & 118.27 & 134.16 & 156.40 & 182.32 \\
\hline Residual Oil & 633.23 & 655.26 & 680.05 & 706.41 & 731.46 & 836.85 & 966.78 & 1096.65 & 1278.48 & 1490.45 \\
\hline Total & 710.70 & 735.42 & 763.25 & 792.83 & 820.94 & 939.23 & 1085.05 & 1230.81 & 1434.87 & 1672.77 \\
\hline \multicolumn{11}{|l|}{ Air Transportation } \\
\hline Jet Fuel & 3311.73 & 3447.43 & 3590.64 & 3718.25 & 3864.95 & 4394.21 & 5088.89 & 5792.36 & 6777.57 & 7930.35 \\
\hline Aviation Gasoline & 42.41 & 42.35 & 42.30 & 42.26 & 42.23 & 42.14 & 42.10 & 42.08 & 41.92 & 41.76 \\
\hline Total & 3354.14 & 3489.78 & 3632.94 & 3760.51 & 3907.17 & 4436.35 & 5130.99 & 5834.43 & 6815.33 & 7961.14 \\
\hline \multicolumn{11}{|l|}{ Miscellaneous Transportation } \\
\hline \multicolumn{11}{|l|}{ Military Use } \\
\hline Jet Fuel & 454.65 & 451.78 & 450.38 & 453.27 & 458.00 & 472.66 & 478.53 & 485.46 & 492.65 & 499.95 \\
\hline Residual Fuel & 8.10 & 8.05 & 8.02 & 8.08 & 8.16 & 8.42 & 8.53 & 8.65 & 8.86 & 9.08 \\
\hline Distillate & 58.81 & 58.44 & 58.25 & 58.63 & 59.24 & 61.14 & 61.89 & 62.79 & 63.82 & 64.86 \\
\hline Total & 521.56 & 518.27 & 516.66 & 519.97 & 525.40 & 542.22 & 548.95 & 556.90 & 565.33 & 573.89 \\
\hline \multicolumn{11}{|l|}{ Bus Transportation } \\
\hline Transit Bus (motor gasoline) & 4.07 & 4.08 & 4.09 & 4.10 & 4.11 & 4.12 & 4.09 & 4.04 & 4.03 & 4.03 \\
\hline Transit Bus (diesel) & 69.70 & 69.87 & 70.11 & 70.27 & 70.41 & 70.59 & 70.05 & 69.18 & 69.24 & 69.30 \\
\hline Intercity Bus (diesel) & 20.04 & 20.09 & 20.16 & 20.20 & 20.24 & 20.29 & 20.14 & 19.89 & 19.91 & 19.92 \\
\hline School Bus (motor gasoline) & 3.27 & 3.28 & 3.29 & 3.30 & 3.31 & 3.31 & 3.29 & 3.25 & 3.24 & 3.24 \\
\hline School Bus (diesel) & 56.10 & 56.23 & 56.42 & 56.55 & 56.66 & 56.81 & 56.38 & 55.68 & 55.73 & 55.77 \\
\hline Total & 153.18 & 153.54 & 154.07 & 154.42 & 154.73 & 155.12 & 153.94 & 152.04 & 152.15 & 152.26 \\
\hline \multicolumn{11}{|l|}{ Rail Transportation } \\
\hline Intercity Rail (electicity) & 8.25 & 8.40 & 8.55 & 8.70 & 8.84 & 9.43 & 10.18 & 10.94 & 11.87 & 12.87 \\
\hline Intercity Rail (diesel) & 12.60 & 12.83 & 13.06 & 13.28 & 13.50 & 14.41 & 15.54 & 16.71 & 18.14 & 19.68 \\
\hline Transit Rail (electricity) & 47.89 & 48.78 & 49.65 & 50.48 & 51.31 & 54.75 & 59.06 & 63.51 & 68.86 & 74.67 \\
\hline Commuter Rail (electricity) & 16.29 & 16.60 & 16.89 & 17.18 & 17.46 & 18.63 & 20.10 & 21.61 & 23.43 & 25.40 \\
\hline Commuter Rail (diesel) & 24.88 & 25.34 & 25.80 & 26.23 & 26.66 & 28.45 & 30.69 & 33.00 & 35.81 & 38.87 \\
\hline Total & 109.92 & 111.95 & 113.96 & 115.87 & 117.77 & 125.67 & 135.57 & 145.77 & 158.11 & 171.48 \\
\hline Recreation Boats & 258.05 & 259.99 & 262.30 & 264.42 & 266.48 & 274.55 & 284.85 & 294.90 & 305.95 & 317.40 \\
\hline Lubricants & 273.10 & 275.02 & 278.17 & 282.92 & 286.96 & 297.68 & 313.67 & 325.91 & 343.50 & 362.03 \\
\hline Pipeline Fuel Natural Gas & 745.82 & 751.92 & 754.40 & 767.84 & 788.86 & 866.37 & 948.13 & 987.94 & 1051.32 & 1118.77 \\
\hline
\end{tabular}


Table 34. Transportation Sector Energy Use by Fuel Type Within a Mode (Trillion Btu per Year)

$\begin{array}{lrrrrrrrrrr} & \mathbf{2 0 0 2} & \mathbf{2 0 0 3} & \mathbf{2 0 0 4} & \mathbf{2 0 0 5} & \mathbf{2 0 0 6} & \mathbf{2 0 1 0} & \mathbf{2 0 1 5} & \mathbf{2 0 2 0} & \mathbf{2 0 2 5} & \mathbf{2 0 3 0} \\ & & & & & & & & & & \\ \text { Total Miscellaneous } & 2061.64 & 2070.69 & 2079.57 & 2105.45 & 2140.18 & 2261.61 & 2385.11 & 2463.47 & 2572.59 & 2686.54 \\ \text { Total Consumption } & 27942.95 & 28472.98 & 29097.76 & 29683.93 & 30283.06 & 32438.40 & 34929.74 & 37136.76 & 40362.87 & 43869.23\end{array}$

$1 /$ Commercial trucks from 8,500 to 10,000 pounds.

2/ Does not include military distillate. Does not include commercial buses.

3 / Does not include passenger rail.

$\mathrm{Btu}=$ British thermal unit.

$\mathrm{N} / \mathrm{A}=$ Not applicable.

Note: Totals may not equal sum of components due to independent rounding. The historical data used for the projections were the most available as of July 31,1999 . The numbers presented for 1998 are estimates and may differ from official EIA data reports. Also. please see EIA data publications and the Short-Term Energy Outlook for the latest estimates for 1999.

Sources: 1998 compressed natural gas volumes: Energy Information Administration (EIA), AEO2000 National Energy Modeling System run AEO2K.D10019KA. Other 1998 values derived using: EIA, Short-Term Energy Outlook, September 1999,

Online. http:/www.eia.doe.gov/pub/forecasting/steo/oldsteos/sep99.html (October 12, 1999); EIA, Fuel Oil and Kerosene Sales

1997, DOE/EIA-0535(97) (Washington, D.C., August 1998); EIA, State Energy Data Report 1996, DOE/EIA-0214(96)

(Washington, DC, Febuary 1999); Oak Ridge National Laboratory, Transportation Energy Book: 17 and 18 (September 1998);

Department of Defense, Defense Fuel Supply Center; and EIA, AEO2000 National Energy Modeling System run

AEO2K.D100199A. Projections: EIA, AEO2000 National Energy Modeling System run AEO2K.D100199A. 
Table 35. Light-Duty Vehicle Energy Consumption by Technology Type and Fuel Type (Trillion Btu)

\begin{tabular}{|c|c|c|c|c|c|c|c|c|c|c|}
\hline & 2002 & 2003 & 2004 & 2005 & 2006 & 2010 & 2015 & 2020 & 2025 & 2030 \\
\hline \multicolumn{11}{|c|}{ Light-Duty Consumption by Technology Type } \\
\hline Gasoline ICE Vehicles & 15539.39 & 15742.56 & 16035.33 & 16291.53 & 16568.42 & 17579.31 & 18673.73 & 19697.96 & 21171.39 & 22755.04 \\
\hline TDI Diesel ICE & 160.20 & 150.93 & 145.78 & 145.12 & 139.70 & 153.39 & 234.17 & 323.81 & 354.58 & 388.27 \\
\hline \multicolumn{11}{|l|}{ Alternative-Fuel Vehicles } \\
\hline \multicolumn{11}{|l|}{ Alcohol Fuel Technology } \\
\hline Methanol-Flex Fuel ICE & 101.97 & 131.00 & 158.99 & 185.93 & 212.14 & 292.21 & 335.99 & 339.76 & 676.76 & 1348.05 \\
\hline Methanol ICE & 0.26 & 0.42 & 0.66 & 1.03 & 1.60 & 7.85 & 26.32 & 45.80 & 252.18 & 1388.51 \\
\hline Ethanol-Flex Fuel ICE & 63.42 & 80.47 & 99.20 & 118.12 & 137.07 & 200.24 & 234.81 & 231.46 & 468.34 & 947.65 \\
\hline Ethanol Ice & 0.12 & 0.20 & 0.32 & 0.52 & 0.81 & 3.65 & 11.28 & 18.03 & 96.20 & 513.29 \\
\hline Total Alcohol & 165.77 & 212.09 & 259.18 & 305.60 & 351.61 & 503.94 & 608.40 & 635.05 & 1303.47 & 2675.44 \\
\hline \multicolumn{11}{|l|}{ Natural Gas Technology } \\
\hline CNG ICE & 91.82 & 111.11 & 129.33 & 145.26 & 158.41 & 200.34 & 242.75 & 271.53 & 495.66 & 904.79 \\
\hline CNG Bi-fuel & 5.05 & 6.31 & 7.61 & 8.82 & 9.93 & 13.01 & 13.70 & 11.92 & 21.29 & 38.02 \\
\hline LPG ICE & 48.66 & 54.77 & 60.61 & 65.73 & 70.01 & 83.96 & 98.21 & 107.43 & 150.69 & 211.38 \\
\hline LPG Bi-fuel & 3.31 & 4.06 & 4.84 & 5.56 & 6.21 & 7.81 & 7.59 & 5.97 & 9.84 & 16.23 \\
\hline Total Natural Gas Technology & 148.84 & 176.26 & 202.40 & 225.37 & 244.55 & 305.13 & 362.24 & 396.85 & 650.71 & 1066.95 \\
\hline \multicolumn{11}{|l|}{ Electric Technology } \\
\hline Electric Vehicle & 1.77 & 7.97 & 13.91 & 19.35 & 24.18 & 41.13 & 60.19 & 72.04 & 228.90 & 727.24 \\
\hline Electric-Diesel Hybrid & 0.00 & 0.00 & 0.00 & 0.00 & 0.00 & 0.01 & 0.02 & 0.02 & 0.02 & 0.02 \\
\hline Total Electricity & 1.77 & 7.97 & 13.91 & 19.35 & 24.18 & 41.14 & 60.21 & 72.07 & 228.99 & 727.59 \\
\hline \multicolumn{11}{|l|}{ Fuel Cell Technology } \\
\hline Fuel Cell Gasoline & 0.00 & 0.00 & 0.00 & 0.00 & 0.00 & 0.00 & 0.00 & 0.00 & 0.00 & 0.00 \\
\hline Fuel Cell Methanol & 0.00 & 0.00 & 0.00 & 0.00 & 0.00 & 0.00 & 0.00 & 0.00 & 0.00 & 0.00 \\
\hline Fuel Cell Hydrogen & 0.00 & 0.00 & 0.00 & 0.00 & 0.00 & 0.00 & 0.00 & 0.00 & 0.00 & 0.00 \\
\hline Total Fuel Cell & 0.00 & 0.00 & 0.00 & 0.00 & 0.00 & 0.00 & 0.00 & 0.00 & 0.00 & 0.00 \\
\hline \multicolumn{11}{|c|}{ Light-Duty Consumption by Fuel Type 1/ } \\
\hline Motor Gasoline & 15646.60 & 15877.02 & 16203.42 & 16488.80 & 16793.74 & 17890.77 & 19016.85 & 20013.15 & 21578.62 & 23266.55 \\
\hline Distillate (diesel) & 160.20 & 150.93 & 145.78 & 145.12 & 139.70 & 153.39 & 234.17 & 323.81 & 354.58 & 388.27 \\
\hline Methanol & 40.09 & 50.67 & 55.12 & 63.29 & 72.07 & 100.96 & 131.99 & 151.95 & 296.26 & 577.62 \\
\hline Ethanol & 17.44 & 21.98 & 27.15 & 32.42 & 37.73 & 57.10 & 73.67 & 79.38 & 169.05 & 360.00 \\
\hline Compressed Natural Gas & 94.36 & 114.28 & 133.15 & 149.69 & 163.39 & 206.87 & 249.62 & 277.50 & 506.31 & 923.76 \\
\hline Liquid Petroleum Gas & 49.69 & 56.03 & 62.13 & 67.49 & 71.98 & 86.44 & 100.63 & 109.31 & 153.63 & 215.93 \\
\hline Electricity & 1.77 & 7.97 & 13.91 & 19.35 & 24.18 & 41.13 & 60.19 & 72.04 & 228.90 & 727.24 \\
\hline Liquid Hydrogen & 0.00 & 0.00 & 0.00 & 0.00 & 0.00 & 0.00 & 0.00 & 0.00 & 0.00 & 0.00 \\
\hline
\end{tabular}

1 / Includes personal vehicles and fleet vehicles. Includes both cars and trucks.

TDI = Turbo Direct Injection.

Btu $=$ British thermal unit.

$\mathrm{CNG}=$ Compressed natural gas.

$\mathrm{LPG}=$ Liquid petroleum gas.

ICE = Internal combustion engine.

$\mathrm{N} / \mathrm{A}=$ Not applicable.

Note: Totals may not equal sum of components due to independent rounding. The historical data used for the projections were the most available as of July 31, 1999. The numbers presented for 1998 are estimates and may differ from official EIA data reports. Also. please see EIA data publications and the Short-Term Energy Outlook for the latest estimates for 1999.

Source: Energy Information Administration, AEO2000 National Energy Modeling System run AEO2K.D100199A. 
Table 45. Light-Duty Vehicle Sales by Technology Type (Thousands) United States Total

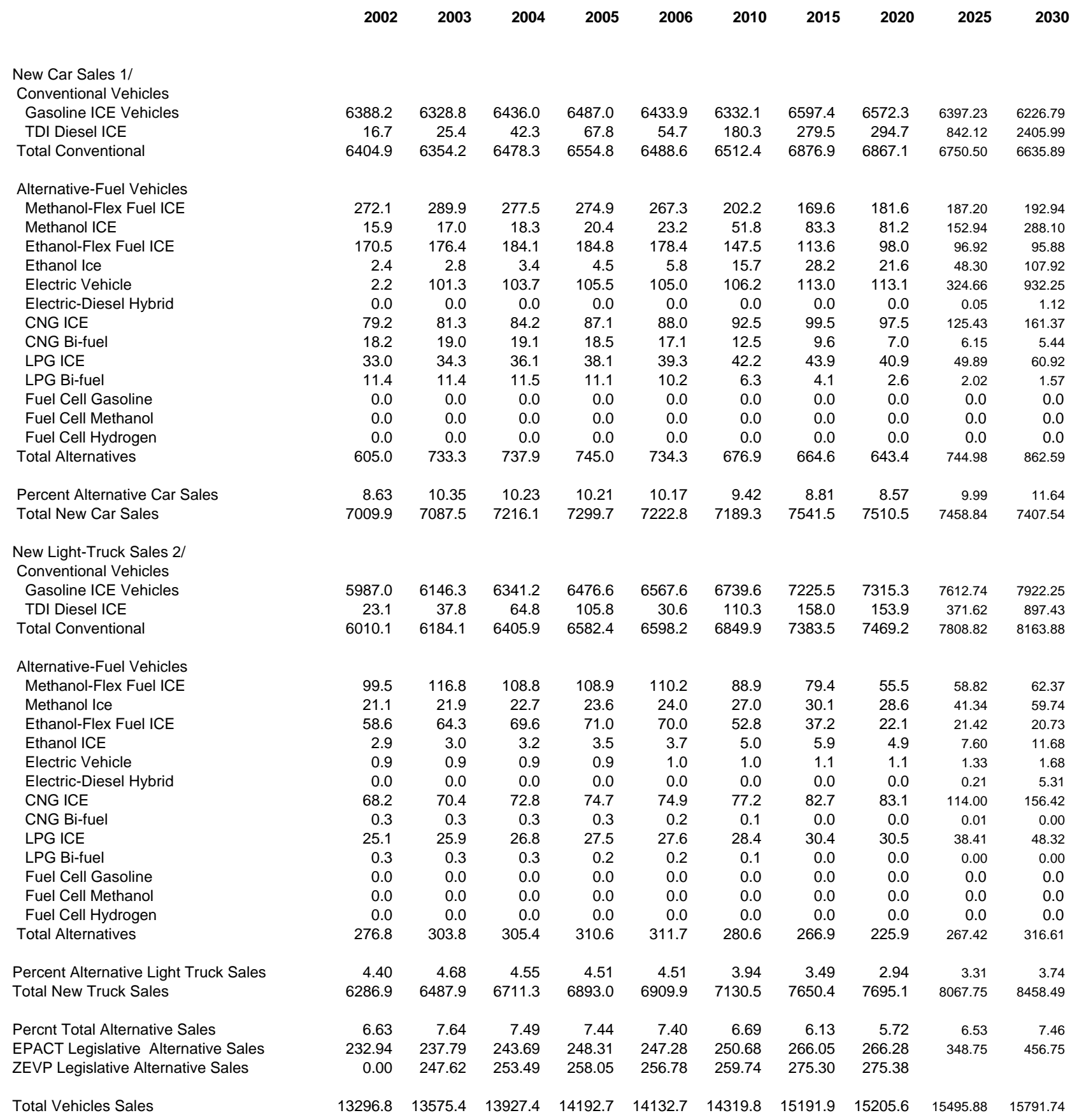

1 / Includes personal and fleet light-duty cars.

2/ Includes personal and fleet light-duty trucks.

TDI = Turbo Direct Injection

$\mathrm{CNG}=$ Compressed natural gas.

$\mathrm{LPG}=$ Liquid petroleum gas

ICE = Internal combustion engine.

EPACT $=$ Energy Policy Act of 1992.

ZEVP = Zero emission vehicles from the low emission vehicle program.

$\mathrm{N} / \mathrm{A}=$ Not applicable.

Note: Totals may not equal sum of components due to independent rounding. The historical data used for the projections were the most 
Table 45. Light-Duty Vehicle Sales by Technology Type (Thousands) United States Total

available as of July 31, 1999. The numbers presented for 1998 are estimates and may differ from official EIA data reports. Also. please see EIA data publications and the Short-Term Energy Outlook for the latest estimates for 1999.

Sources: 1998 derived using: California Air Resources Board (CARB), "Proposed Regulations for Low-Emission Vehicles and Clean Fuels, Staff Report"; CARB, "Proposed Amendments to California Exhaust and Evaporative Emission Standards and Test Procedures for Passenger, Light-Duty Trucks and Medium-Duty Vehicle - LEVII and Proposed Amendments to California Motor Vehicle Certification: Assembly-Line and

In-Use Test Requirements - CAP 2000," (El Monte, CA, September 1998);US Department of Energy, Argonne National Labortory, National Alternative-Fuel Survey, Model Version 28, July 21, 1998; Energy Information Administration (EIA), Describing Current and Potential Markets Alternative-Fuel Vehicles, DOE/EIA-0604(96)

(Washington, DC, March 1996); EIA, Alternatives to Traditional Transportation Fuels 1996, DOE/EIA-0585(96)

(Washington, DC, December 1997); and EIA, AEO2000 National Energy Modeling System run AEO2K.D100199A.

Projections: EIA, AEO2000 National Energy Modeling System run AEO2K.D100199A. 
Table 46. Light-Duty Vehicle Stock by Technology Type (Millions)

$\begin{array}{llllllllll}2002 & 2003 & 2004 & 2005 & 2006 & 2010 & 2015 & 2020 & 2025 & 2030\end{array}$

Light-Duty Car Stock 1

Conventional Vehicles

Gasoline ICE Vehicles

TDI Diesel ICE

Total Conventional

Alternative-Fuel Vehicles

Alcohol Fuel Technology

Methanol-Flex Fuel ICE

Methanol ICE

Ethanol-Flex Fuel ICE

Ethanol Ice

Natural Gas Technology

CNG ICE

CNG Bi-fuel

LPG ICE

LPG Bi-fuel

Electric Technology

Electric Vehicle

Electric-Diesel Hybrid

Fuel Cell Technology

Fuel Cell Gasoline

Fuel Cell Methanol

Fuel Cell Hydrogen

Total Alternatives

Total Car Stock

Light-Duty Truck Stock 1/

Conventional Vehicles

Gasoline ICE Vehicles

TDI Diesel ICE

Total Conventional

Alternative-Fuel Vehicles

Alcohol Fuel Technology

Methanol-Flex Fuel ICE

Methanol ICE

Ethanol-Flex Fuel ICE

Ethanol Ice

Natural Gas Technology

CNG ICE

CNG Bi-fuel

LPG ICE

LPG Bi-fuel

Electric Technology

Electric Vehicle

Electric-Diesel Hybrid

Fuel Cell Technology

Fuel Cell Gasoline

Fuel Cell Methanol

Fuel Cell Hydrogen

Total Alternatives

Total Truck Stock

Total Vehicle Stock

$\begin{array}{rrrrrrrrrr}112.33 & 109.84 & 107.58 & 105.51 & 103.55 & 96.88 & 92.36 & 91.06 & 85.43 & 80.14 \\ 0.51 & 0.44 & 0.41 & 0.41 & 0.41 & 0.80 & 1.87 & 2.95 & 3.65 & 4.52 \\ 112.84 & 110.28 & 107.99 & 105.92 & 103.96 & 97.68 & 94.23 & 94.01 & 88.64 & 83.58\end{array}$

$\begin{array}{rrrrrrrrrr}1.14 & 1.42 & 1.69 & 1.95 & 2.19 & 2.84 & 3.04 & 2.95 & 5.47 & 10.15 \\ 0.00 & 0.01 & 0.01 & 0.02 & 0.02 & 0.11 & 0.38 & 0.66 & 3.58 & 19.39 \\ 0.72 & 0.89 & 1.07 & 1.25 & 1.42 & 1.93 & 2.12 & 1.98 & 3.72 & 6.97 \\ 0.00 & 0.00 & 0.00 & 0.01 & 0.01 & 0.05 & 0.15 & 0.24 & 1.27 & 6.69 \\ & & & & & & & & & \\ 0.34 & 0.42 & 0.49 & 0.57 & 0.65 & 0.93 & 1.18 & 1.31 & 2.53 & 4.88 \\ 0.08 & 0.09 & 0.11 & 0.13 & 0.14 & 0.18 & 0.19 & 0.16 & 0.28 & 0.48 \\ 0.17 & 0.20 & 0.23 & 0.27 & 0.30 & 0.41 & 0.52 & 0.57 & 0.92 & 1.48 \\ 0.05 & 0.06 & 0.07 & 0.08 & 0.09 & 0.11 & 0.10 & 0.08 & 0.13 & 0.20 \\ & & & & & & & & & \\ 0.01 & 0.11 & 0.21 & 0.32 & 0.42 & 0.81 & 1.22 & 1.47 & 5.90 & 23.67 \\ 0.00 & 0.00 & 0.00 & 0.00 & 0.00 & 0.00 & 0.00 & 0.00 & 0.00 & 0.00 \\ & & & & & & & & & \\ 0.00 & 0.00 & 0.00 & 0.00 & 0.00 & 0.00 & 0.00 & 0.00 & 0.00 & 0.00 \\ 0.00 & 0.00 & 0.00 & 0.00 & 0.00 & 0.00 & 0.00 & 0.00 & 0.00 & 0.00 \\ 0.00 & 0.00 & 0.00 & 0.00 & 0.00 & 0.00 & 0.00 & 0.00 & 0.00 & 0.00 \\ 2.51 & 3.21 & 3.90 & 4.59 & 5.24 & 7.38 & 8.91 & 9.42 & 18.44 & 36.10 \\ & & & & & & & & & \\ 115.35 & 113.49 & 111.89 & 110.51 & 109.20 & 105.07 & 103.15 & 103.44 & 99.58 & 95.86\end{array}$

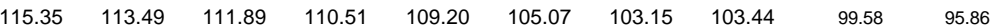

$1 /$ Includes personal and fleet vehicles.

TDI = Turbo Direct Injection.

ICE = Internal combustion engine.

$\mathrm{N} / \mathrm{A}=$ Not applicable

Note: Totals may not equal sum of components due to independent rounding. The historical data used for the projections were the most available as of July 31,1999 . The numbers presented for 1998 are estimates and may differ from official EIA data reports. Also. please

see EIA data publications and the Short-Term Energy Outlook for the latest estimates for 1999.

Sources: 1998 derived using: Energy Information Administration (EIA), Household Vehicles Energy Consumption

1994, DOE/EIA-0464(94) (Washington, D.C., August 1997); ElA, Describing Current and Potential Markets for

Alternative-Fuel Vehicles, DOE/EIA-0604(96) (Washington, DC, March 1996); EIA, Alternatives to Traditional

Transportation Fuels 1996, DOE/EIA-0585(96) (Washington, DC, December 1997); Federal Highway Administration, Highway

Statistics 1997, (Washington DC, November 1998); R.L. Polk and Company, Transportation Energy Data Book: Edition 18,

"Automobiles in Operation and Vehicle Travel by Age in 1996" and "Trucking Operation and Vehicle Travel by Age in

1995", US Department of Energy, ORNL-6941, (Oak Ridge, TN., September 1998); and EIA, AEO2000 National Energy Modeling

System run AEO2K.D100199A. Projections: EIA, AEO2000 National Energy Modeling System run AEO2K.D100199A. 
Table 47. Light-Duty Vehicle MPG by Technology Type (MPG Gasoline Equivalents)

$\begin{array}{llllllllll}2002 & 2003 & 2004 & 2005 & 2006 & 2010 & 2015 & 2020 & 2025 & 2030\end{array}$

Automobiles 1

Conventional Vehicles

Gasoline ICE Vehicles

TDI Diesel ICE

Alternative-Fuel Vehicles

Alcohol Fuel Technology

Methanol-Flex Fuel ICE

Methanol ICE

Ethanol-Flex Fuel ICE

Ethanol Ice

Natural Gas Technology

CNG ICE

CNG Bi-fuel

LPG ICE

LPG Bi-fuel

Electric Technology

Electric Vehicle

Electric-Diesel Hybrid

Fuel Cell Technology

Fuel Cell Gasoline

Fuel Cell Methanol

Fuel Cell Hydrogen

Average New Car MPG

$\begin{array}{llllllllll}29.00 & 29.77 & 29.75 & 29.84 & 30.05 & 30.94 & 31.17 & 31.09 & 31.82 & 32.56 \\ 39.31 & 39.84 & 39.76 & 39.87 & 39.84 & 40.70 & 40.84 & 40.53 & 41.05 & 41.57\end{array}$

Light-Duty Trucks 1/

Conventional Vehicles

Gasoline ICE Vehicles

TDI Diesel ICE

$\begin{array}{llll}31.03 & 31.75 & 31.69 & 31.77 \\ 30.70 & 31.51 & 31.59 & 31.89\end{array}$

$\begin{array}{lllllllll}31.51 & 31.59 & 31.89 & 32.33 & 33.92 & 34.16 & 33.93 & 34.91 & 35.92\end{array}$

$\begin{array}{llllllllll}30.74 & 31.47 & 31.41 & 31.49 & 31.67 & 32.26 & 32.41 & 32.19 & 32.76 & 33.33\end{array}$

$\begin{array}{llllllllll}29.95 & 30.89 & 31.14 & 31.53 & 31.97 & 33.25 & 33.37 & 33.19 & 34.23 & 35.29\end{array}$

$\begin{array}{llllllllll}30.28 & 30.77 & 30.71 & 30.84 & 31.03 & 31.89 & 32.45 & 32.36 & 32.99 & 33.64\end{array}$

$\begin{array}{llllllllll}27.90 & 28.47 & 28.41 & 28.54 & 28.73 & 29.57 & 29.96 & 29.95 & 30.60 & 31.26\end{array}$

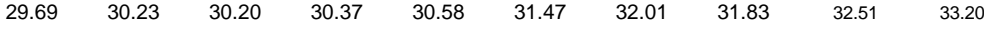

$28.27-28.84-28.77-28.88$

$\begin{array}{llllllllll}32.52 & 30.95 & 33.62 & 37.14 & 41.63 & 46.86 & 46.17 & 45.71 & 49.06 & 52.66\end{array}$

$\begin{array}{llllllllll}32.52 & 30.95 & 33.62 & 37.14 & 41.63 & 46.86 & 46.17 & 45.71 & 49.06 & 52.66 \\ 47.58 & 47.28 & 46.64 & 46.38 & 46.35 & 47.56 & 48.58 & 49.29 & 49.66 & 50.04\end{array}$

$\begin{array}{llllllllll}0.00 & 0.00 & 0.00 & 42.82 & 42.56 & 41.69 & 40.67 & 39.63 & 38.61 & 37.63\end{array}$

$\begin{array}{llllllllll}0.00 & 0.00 & 0.00 & 45.65 & 45.36 & 44.31 & 43.13 & 42.07 & 40.93 & 39.83\end{array}$

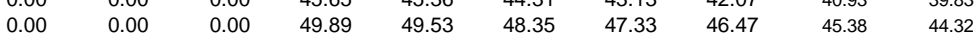

$\begin{array}{llllllllll}29.15 & 29.94 & 29.96 & 30.12 & 30.36 & 31.40 & 31.71 & 31.63 & 32.47 & 33.34\end{array}$

Alternative-Fuel Vehicles

Alcohol Fuel Technology

Methanol-Flex Fuel ICE

Methanol ICE

Ethanol-Flex Fuel ICE

Ethanol Ice

Natural Gas Technology

CNG ICE

CNG Bi-fuel

LPG ICE

LPG Bi-fuel

Electric Technology

Electric Vehicle

Electric-Diesel Hybrid

Fuel Cell Technology

Fuel Cell Gasoline

Fuel Cell Methanol

Fuel Cell Hydrogen

Average New Truck MPG

Fleet Average Stock Car MPG 2/

Fleet Average Stock Truck MPG 2

Fleet Aver. Stock Vehicle MPG 2/

$20.77-21.01 \quad 20.94$

23.25

23.77

$\begin{array}{ll} & \end{array}$

$\begin{array}{llllllllll}21.36 & 21.66 & 21.66 & 21.70 & 21.83 & 22.18 & 22.70 & 23.02 & 23.56 & 24.12 \\ 20.94 & 21.64 & \end{array}$

$\begin{array}{llllllllll}21.34 & 21.65 & 21.60 & 21.64 & 21.77 & 22.06 & 22.55 & 22.92 & 23.45 & 23.99\end{array}$

$\begin{array}{llllllllll}19.53 & 19.86 & 19.89 & 20.11 & 20.47 & 21.55 & 22.42 & 22.74 & 23.72 & 24.75\end{array}$

$\begin{array}{llllllllll}20.19 & 20.46 & 20.42 & 20.55 & 20.79 & 21.23 & 21.90 & 22.56 & 23.29 & 24.05 \\ 21.21 & 21.41 & 21.34 & 21.39 & 21.54 & 21.91 & 22.29 & 22.89 & 23.35 & 23.83\end{array}$

$\begin{array}{lllllll}21.21 & 21.41 & 21.34 & 21.39 & 21.54 & 21.91 & 22.29\end{array}$

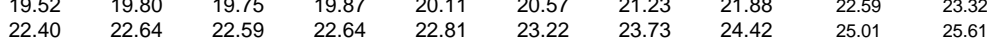

$\begin{array}{llllllllll}22.98 & 25.15 & 27.32 & 30.11 & 33.68 & 37.48 & 36.25 & 35.42 & 38.85 & 42.62\end{array}$

$\begin{array}{llllllllll}35.57 & 35.78 & 35.53 & 35.53 & 35.78 & 36.45 & 36.97 & 37.36 & 38.06 & 38.77\end{array}$

$\begin{array}{rrrrrrrrrr}0.00 & 0.00 & 0.00 & 0.00 & 0.00 & 0.00 & 34.54 & 33.76 & 32.99 & 32.24 \\ 0.00 & 0.00 & 0.00 & 45.57 & 45.15 & 43.74 & 42.34 & 41.40 & 40.09 & 38.83 \\ 0.00 & 0.00 & 0.00 & 0.00 & 0.00 & 0.00 & 0.00 & 0.00 & 0.00 & 0.00\end{array}$

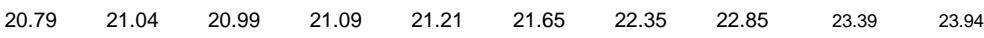

$\begin{array}{llllllllll}24.16 & 24.42 & 24.56 & 24.73 & 24.87 & 25.47 & 26.16 & 26.52 & 27.25 & 27.99 \\ 16.81 & 16.89 & 16.89 & 16.92 & 16.92 & 17.00 & 17.15 & 17.37 & 17.50 & 17.62\end{array}$

$\begin{array}{llllllllll}16.81 & 16.89 & 16.89 & 16.92 & 16.92 & 17.00 & 17.15 & 17.37 & 17.50 & 17.62\end{array}$

$\begin{array}{llllllllll}20.51 & 20.56 & 20.52 & 20.51 & 20.47 & 20.43 & 20.49 & 20.60 & 20.59 & 20.58\end{array}$

1/ Fuel efficiencies are EPA rated. Includes personal and fleet vehicles.

2/ Stock values are on road efficiencies. Includes personal vehicles, fleet vehicles, and freight light trucks.

TDI = Turbo Direct Injection.

$\mathrm{CNG}=$ Compressed natural gas

$\mathrm{LNG}=$ Liquid natural gas

$M P G=$ Miles per Gallon.

ICE = Internal combustion engine.

$\mathrm{N} / \mathrm{A}=$ Not applicable.

Note: The historical data used for the projections were the most available as of July 31, 1999. The numbers presented for 1998

are estimates and may differ from official EIA data reports. Also. please see EIA data publications and the Short-Term Energy

Outlook for the latest estimates for 1999

Sources: 1998 derived using: Energy and Environmental Analysis Inc., Update to the Fuel Economy Model, prepared for

Energy Information Administration (EIA) (Washington, DC, June 1998); National Highway Traffic and Safety Administration,

Mid-Model Year Fuel Economy Reports from Auto Manufacturers, 1998; Federal Highway Administration, Highway Statistics 1997,

(November 1998); United States Department of Commerce, Bureau of the Census, Truck Inventory and Use Survey, TC92-T-52

(Washington, DC, May 1995);and EIA, AEO2000 National Energy Modeling System run AEO2K.D100199A. Projections: EIA, AEO2000

National Energy Modeling System run AEO2K.D100199A. 
Table 49. Light-Duty Vehicle VMT by Technology Type

(Billion Miles, Unless Otherwise Noted)

Conventional Vehicles 1/

Gasoline ICE Vehicles

TDI Diesel ICE

$\begin{array}{rrrrrrrrrr}2002 & 2003 & 2004 & 2005 & 2006 & 2010 & 2015 & 2020 & 2025 & 2030 \\ & & & & & & & & & \\ 2543.6 & 2583.1 & 2625.0 & 2663.8 & 2703.5 & 2856.2 & 3032.2 & 3208.5 & 3443.29 & 3695.23 \\ 27.2 & 25.7 & 25.0 & 25.2 & 24.6 & 30.1 & 51.1 & 73.6 & 85.23 & 98.68\end{array}$

Alternative-Fuel Vehicles

Alcohol Fuel Technology

Methanol-Flex Fuel ICE

Methanol ICE

Ethanol-Flex Fuel ICE

Ethanol Ice

Natural Gas Technology

CNG ICE

CNG Bi-fuel

LPG ICE

LPG Bi-fuel

Electric Technology

Electric Vehicle

Electric-Diesel Hybrid

Fuel Cell Technology

Fuel Cell Gasoline

Fuel Cell Methanol

Fuel Cell Hydrogen

VMT Equation Components

Total VMT (billion miles)

VMT/Driving Population (thousand miles)

Driving Population (million)

Price Effects

Motor Gasoline Price (1987 dollars/million Btı

Fleet Miles per Gallon

Real Cost of Driving per Mile (1987 cents)

Point Price Elasticity

$\begin{array}{rrr}21.0 & 27.0 & 32.7 \\ 0.1 & 0.1 & \\ 12.0 & 15.2 & 18.8 \\ 0.0 & 0.0 & \\ & & \\ 14.9 & 18.2 & 21.2 \\ 0.9 & 1.2 & \\ 7.7 & 8.8 & \\ 0.6 & 0.8 \\ & \\ 0.4 & 1.7 \\ 0.0 & 0.0 \\ & & \\ 0.0 & 0.0 \\ 0.0 & 0.0 \\ 0.0 & 0.0 & \\ & & \end{array}$

Income Effects

Disposable Income (billion 1987 dollars)

Point Income Elasticity

\section{5}

11.7

217.0

2681.9

11.8

219.2

2738.1

12.0

221.4

7.49
20.61
4.546
-0.040

$7.52 \quad 7.56$

$20.65 \quad 20.59$

$4.553 \quad 4.591$

$-0.040 \quad-0.040$$$
\begin{array}{r}
4932 \\
0.4
\end{array}
$$

$\begin{array}{lll}932.6 & 5049.2 & 5190.5\end{array}$

$\begin{array}{lll}0.766 & 0.774 & 0.780 \\ 0.257 & 0.257 & 0.256\end{array}$

$\begin{array}{rrr}2791.5 & 2844.1 \\ 12.1 & 12.2\end{array}$

$223.7 \quad 226.0$

3048.3

12.6

235.2

3282.4
13.0

245.6

3497.6

13.5

255.3

14.06

267.27

7.62
20.57
4.630
-0.040

$\begin{array}{rr}7.62 & 7.63 \\ 20.53 & 20.48\end{array}$

$4.643 \quad 4.663$

7.63

20.52
4.650

7.60

20.63

4.604

$-0.035$

7.93

20.59

4.81

$-0.04$

$\begin{array}{lll}5323.0 & 5453.2 \quad 5986.5\end{array}$

$-0.037$

0.463

0.466

0.481

6716.6

7485.5

8426.97

0.54

9486.88

Demographic Driving Population Effect

Percentage Female Driving Population

Point Demographic Elasticity

0.257

0.785

0.256

0.789
0.255

0.796

0.796

0.240

0.796

0.232

$0.82 \quad 0.84$

$1 /$ Includes personal and fleet vehicles. Includes both cars and light trucks.

$\mathrm{TDI}=$ Turbo Direct Injection.

$\mathrm{CNG}=$ Compressed natural gas.

$\mathrm{LNG}=$ Liquid natural gas .

VMT $=$ Vehicle miles traveled.

$\mathrm{ICE}=$ Internal combustion engine.

$\mathrm{Btu}=$ British thermal unit.

$\mathrm{N} / \mathrm{A}=$ Not applicable.

Note: The historical data used for the projections were the most available as of July 31, 1999. The numbers presented for 1998 are estimates and may differ from official EIA data reports. Also. please see EIA data publications and the Short-Term Energy

Outlook for the latest estimates for 1999.

Sources: 1998 derived using: Federal Highway Administration, Highway Statistics 1996, (November 1997);

Oak Ridge National Laboratory, Transportation Energy Data Book: 18,(September 1998); United States Department

of Commerce, Bureau of the Census, Truck Inventory and Use Survey, TC92-T-52 (Washington, DC, May 1995); and

Energy Information Administration (EIA), AEO2000 National Energy Modeling System run AEO2K.D100199A.

Projections: EIA, AEO2000 National Energy Modeling System run AEO2K.D100199A. 
Table 50. Summary of New Light-Duty Vehicle Size Class Attributes

$\begin{array}{llllllllll}2002 & 2003 & 2004 & 2005 & 2006 & 2010 & 2015 & 2020 & 2025 & 2030\end{array}$

Personal Vehicles

New Fuel Efficiency EPA Rated

Conventional Cars (MPG)

Minicompact

Subcompact

$\begin{array}{llllll}32.624 & 33.261 & 33.255 & 33.302 & 33.461 & 34.073\end{array}$

Compact

Mid-size

Large

Two Seater

Average New Car

Average New Car On-Road MPG

$\begin{array}{lll}27.925 & 28.537 & 28.521 \\ 25.304 & 26.033 & 26.031\end{array}$

$\begin{array}{lll}25.304 & 26.033 & 26.031 \\ 25.557 & 26.179 & 26.175\end{array}$

$29.578 \quad 30.410 \quad 30.386$

$25.246 \quad 26.026 \quad 25.974$

$32.526 \quad 32.719 \quad 33.543$

$28.633 \quad 28.855 \quad 29.743$

$26.167 \quad 26.402 \quad 27.506$

$26.324 \quad 26.560 \quad 27.303$

$30.478 \quad 30.683 \quad 31.557$

$26.053 \quad 26.195 \quad 26.806$

$29.687 \quad 29.806$

$33.985 \quad 33.658$

$33.622 \quad 33.389$

$29.995 \quad 29.969$

$28.111 \quad 28.290$

$27.437 \quad 27.387$

$31.745 \quad 31.625$

Conventional Light Trucks

Small Pickup

Large Pickup

Small Van

Large Van

Small Utility

Large Utility

Average New Light Truck

Average New LT On-Road MPG

$24.162 \quad 24.323 \quad 24.225$

$\begin{array}{lll}18.482 & 18.597 & 18.505 \\ 25.174 & 25.478 & 25.450\end{array}$

$\begin{array}{lll}25.174 & 25.478 & 25.450 \\ 19.188 & 19.512 & 19.492\end{array}$

$21.760 \quad 22.056 \quad 22.006$

$14.791 \quad 14.989 \quad 14.998$

$20.866 \quad 21.087 \quad 21.014$

$24.142 \quad 24.169 \quad 24.223$

$26.767 \quad 26.500$

$30.72 \quad 31.66$

$34.09 \quad 34.53$

$34.04 \quad 34.71$

$30.66 \quad 31.36$

$29.19 \quad 30.12$

$\begin{array}{ll}29.19 & 30.12 \\ 32.00 & 28.64\end{array}$

$32.35 \quad 33.09$

Degradation Factors 1/

Cars

Light Trucks

$16.841 \quad 17.065 \quad 16.985$

$\begin{array}{lll}18.575 & 18.740 & 19.131\end{array}$

$25.489 \quad 25.632 \quad 25.712$

$\begin{array}{lll}19.660 & 19.942 \quad 20.603\end{array}$

$\begin{array}{lll}22.032 & 22.183 & 22.559\end{array}$

$\begin{array}{lll}15.127 & 15.337 \quad 15.886\end{array}$

$21.076 \quad 21.212 \quad 21.556$

$24.680 \quad 24.994$

$19.882 \quad 20.473$

$26.263 \quad 26.840$

$\begin{array}{ll}21.502 & 22.259\end{array}$

$23.196 \quad 23.567$

$16.511 \quad 16.980$

$22.197 \quad 22.659$

$26.94 \quad 27.38$

$\begin{array}{lll}0.854 & 0.856 & 0.855\end{array}$

(7).034.

$17.683 \quad 17.932$

$25.28 \quad 25.57$

$20.95 \quad 21.43$

$27.40 \quad 27.98$

$23.24 \quad 24.27$

$24.17 \quad 24.80$

$16.94 \quad 16.90$

$\begin{array}{ll}16.94 & 16.90 \\ 23.08 & 23.50\end{array}$

$18.15 \quad 18.36$

$0.807 \quad 0.809$

0.855
0.808

$\begin{array}{lll}0.855 & 0.854 & 0.849\end{array}$

$0.843 \quad 0.838$

0.797

0.791

$\begin{array}{ll}0.83 & 0.83 \\ 0.79 & 0.78\end{array}$

New Fuel Efficiency by

Size Class 2/

Alternative-Fuel Cars

Minicompact

Subcompact

Compact

Midsize

Large

2-Seater

Average New Alternative Cars

Alternative-Fuel Light Trucks

Small Pickup

Large Pickup

Small Van

Large Van

Small Utility

Large Utility

Average New Alt. Light Trucks

Fleet Vehicles

New Fuel Efficiency EPA Rated

Cars

Light Trucks

Average On Road MPG

Cars

Light Trucks

$\begin{array}{rrrrrrrrrr}0.00 & 0.00 & 0.00 & 0.00 & 0.00 & 0.00 & 0.00 & 0.00 & 0.00 & 0.00 \\ 36.874 & 37.540 & 37.479 & 37.510 & 37.672 & 38.506 & 38.614 & 38.214 & 38.71 & 39.22 \\ 30.725 & 31.551 & 31.482 & 31.533 & 31.718 & 32.576 & 32.689 & 32.384 & 32.97 & 33.56 \\ 29.118 & 29.738 & 29.697 & 29.822 & 30.064 & 31.001 & 31.396 & 31.287 & 32.01 & 32.75 \\ 27.224 & 27.976 & 27.989 & 28.152 & 28.418 & 29.710 & 30.747 & 30.953 & 32.05 & 33.19 \\ 30.195 & 30.872 & 33.434 & 36.774 & 40.999 & 45.906 & 45.658 & 45.251 & 50.08 & 55.41 \\ 25.689 & 26.279 & 26.680 & 27.299 & 28.145 & 29.616 & 29.851 & 29.682 & 30.87 & 32.10 \\ & & & & & & & & & \\ 25.019 & 25.252 & 25.153 & 25.084 & 25.145 & 25.436 & 26.093 & 26.299 & 26.73 & 27.17 \\ 18.237 & 18.354 & 18.257 & 18.333 & 18.508 & 18.986 & 19.857 & 20.461 & 21.04 & 21.63 \\ 22.720 & 23.025 & 22.956 & 22.952 & 23.084 & 23.554 & 24.321 & 24.590 & 25.18 & 25.78 \\ 18.455 & 18.770 & 18.749 & 18.920 & 19.205 & 19.936 & 20.947 & 21.712 & 22.75 & 23.83 \\ 21.229 & 21.528 & 21.455 & 21.467 & 21.601 & 22.015 & 22.670 & 22.976 & 23.55 & 24.15 \\ 16.568 & 16.791 & 16.791 & 16.936 & 17.171 & 17.778 & 18.478 & 18.999 & 19.75 & 20.54 \\ 20.371 & 20.620 & 20.560 & 20.615 & 20.786 & 21.284 & 22.061 & 22.506 & 23.16 & 23.83 \\ & & & & & & & & & \\ 27.584 & 28.230 & 28.217 & 28.338 & 28.563 & 29.506 & 29.860 & 29.873 & 30.64 & 31.43 \\ 20.513 & 20.785 & 20.742 & 20.844 & 21.058 & 21.527 & 22.289 & 22.901 & 23.63 & 24.39 \\ & & & & & & & & & \end{array}$

New Vehicle Sales Shares (percent)

Conventional Cars

Minicompact

Subcompact

Compact

Mid-Size

Large

Two Seater

Conventional Light Trucks

Small Pickup

Large Pickup

Small Van

$\begin{array}{llllllllll}0.004 & 0.004 & 0.004 & 0.004 & 0.004 & 0.004 & 0.005 & 0.005 & 0.00 & 0.00 \\ 0.167 & 0.165 & 0.163 & 0.162 & 0.161 & 0.156 & 0.151 & 0.146 & 0.14 & 0.14 \\ 0.389 & 0.389 & 0.391 & 0.393 & 0.393 & 0.394 & 0.394 & 0.394 & 0.40 & 0.41 \\ 0.314 & 0.313 & 0.312 & 0.311 & 0.311 & 0.311 & 0.311 & 0.311 & 0.30 & 0.30 \\ 0.119 & 0.120 & 0.121 & 0.122 & 0.123 & 0.127 & 0.133 & 0.137 & 0.14 & 0.14 \\ 0.008 & 0.008 & 0.008 & 0.008 & 0.008 & 0.008 & 0.008 & 0.008 & 0.01 & 0.01 \\ & & & & & & & & & \\ 0.154 & 0.153 & 0.149 & 0.147 & 0.147 & 0.145 & 0.142 & 0.138 & 0.13 & 0.12 \\ 0.200 & 0.198 & 0.194 & 0.193 & 0.192 & 0.188 & 0.184 & 0.178 & 0.17 & 0.17 \\ 0.210 & 0.210 & 0.207 & 0.209 & 0.209 & 0.210 & 0.209 & 0.206 & 0.21 & 0.21\end{array}$


Table 50. Summary of New Light-Duty Vehicle Size Class Attributes

\begin{tabular}{|c|c|c|c|c|c|c|c|c|c|c|}
\hline & 2002 & 2003 & 2004 & 2005 & 2006 & 2010 & 2015 & 2020 & 2025 & 2030 \\
\hline Large Van & 0.019 & 0.018 & 0.017 & 0.017 & 0.017 & 0.017 & 0.017 & 0.016 & 0.02 & 0.01 \\
\hline Small Utility & 0.317 & 0.319 & 0.327 & 0.328 & 0.329 & 0.333 & 0.340 & 0.350 & 0.36 & 0.37 \\
\hline Large Utility & 0.101 & 0.102 & 0.105 & 0.105 & 0.105 & 0.107 & 0.109 & 0.112 & 0.12 & 0.12 \\
\hline \multicolumn{11}{|c|}{ New Vehicle Average Horse Power } \\
\hline \multicolumn{11}{|l|}{ Conventional Cars } \\
\hline Minicompact & 206.056 & 207.351 & 211.521 & 215.644 & 219.400 & 231.121 & 243.312 & 255.316 & 271.47 & 288.65 \\
\hline Compact & 140.472 & 144.726 & 146.887 & 151.607 & 156.268 & 173.584 & 192.668 & 208.428 & 217.04 & 226.01 \\
\hline Mid-Size & 176.824 & 180.355 & 183.453 & 188.465 & 193.349 & 211.404 & 230.111 & 245.959 & 259.78 & 274.38 \\
\hline Large & 225.279 & 230.245 & 234.015 & 238.919 & 243.624 & 261.823 & 281.950 & 297.506 & 322.87 & 350.39 \\
\hline Two Seater & 246.318 & 250.873 & 255.189 & 261.279 & 267.059 & 287.515 & 307.994 & 326.396 & 378.62 & 439.19 \\
\hline Average New Car & 163.193 & 167.327 & 170.013 & 174.912 & 179.774 & 197.947 & 217.548 & 233.808 & 248.35 & 263.79 \\
\hline \multicolumn{11}{|l|}{ Conventional Light Trucks } \\
\hline Small Pickup & 157.396 & 163.849 & 165.631 & 174.437 & 183.413 & 206.671 & 230.727 & 249.470 & 270.33 & 292.93 \\
\hline Small Van & 184.347 & 190.285 & 194.075 & 203.460 & 212.986 & 238.774 & 268.210 & 290.847 & 314.93 & 341.01 \\
\hline Large Van & 232.691 & 236.779 & 240.111 & 246.349 & 252.342 & 271.767 & 292.681 & 308.119 & 335.62 & 365.58 \\
\hline Small Utility & 194.736 & 200.905 & 205.104 & 213.682 & 222.272 & 245.719 & 269.981 & 289.693 & 313.19 & 338.60 \\
\hline Large Utility & 211.182 & 216.941 & 221.368 & 229.625 & 237.687 & 260.920 & 284.573 & 303.541 & 324.59 & 347.09 \\
\hline Average New Light Truck & 198.484 & 204.532 & 208.260 & 216.986 & 225.715 & 249.993 & 275.324 & 295.230 & 320.40 & 347.72 \\
\hline
\end{tabular}

1/ Conversion factor used to convert Environmental Protection Agency rated to "on road" miles per gallon.

2/ Environmental Protection Agency rated miles per gallon.

$\mathrm{MPG}=$ Milers per gallon.

$E P A=$ Environmental Protection Agency.

$\mathrm{N} / \mathrm{A}=$ Not applicable.

Note: The historical data used for the projections were the most available as of July 31, 1999. The numbers presented for 1998 are estimates and may differ from official EIA data reports. Also. please see EIA data publications and the Short-Term Energy Outlook for the latest estimates for 1999.

Sources: 1998 derived using: Energy and Environmental Analysis Inc., Updates to the Fuel Economy Model, prepared for Energy Information Administarion (EIA) (Washington, DC, June 1998); National Highway Traffic and Safety Administration, Mid-Year Fuel Economy Reports from Auto Manufacturers, 1998; Federal Highway Administration, Highway Statistics 1997, (November 1998); Oak Ridge National Laboratory, "Fleet Vehicles in the United States: Composition, Operating

Characteristics, and Fueling Practices," prepared for the U.S. Department of Energy, Office of Transportation Technologies, and Office of Policy (March 1992); and EIA, AEO2000 National Energy Modeling System run AEO2K.D100199A. Projections: EIA, AEO99 National Energy Modeling System run AEO2K.D100199A. 
Table 51. Transportation Fleet Car and Truck Fuel Consumption by Type and Technology (Trillion Btu)

\begin{tabular}{|c|c|c|c|c|c|c|c|c|c|c|}
\hline & 2002 & 2003 & 2004 & 2005 & 2006 & 2010 & 2015 & 2020 & 2025 & 2030 \\
\hline \multicolumn{11}{|l|}{ Cars 1/ } \\
\hline Gasoline Conventional & 930.99 & 879.17 & 861.28 & 854.13 & 852.49 & 825.40 & 833.85 & 849.12 & 800.63 & 754.92 \\
\hline Distillate & 0.00 & 0.00 & 0.00 & 0.00 & 0.00 & 0.00 & 0.00 & 0.00 & 0.00 & 0.00 \\
\hline \multicolumn{11}{|l|}{ Methanol } \\
\hline Flex & 0.00 & 0.00 & 0.00 & 0.00 & 0.00 & 0.00 & 0.00 & 0.00 & 0.00 & 0.00 \\
\hline \multicolumn{11}{|l|}{ Ethanol } \\
\hline Flex & 0.00 & 0.00 & 0.00 & 0.00 & 0.00 & 0.00 & 0.00 & 0.00 & 0.00 & 0.00 \\
\hline Neat & 0.19 & 0.22 & 0.25 & 0.27 & 0.27 & 0.26 & 0.26 & 0.27 & 0.42 & 0.65 \\
\hline CNG & 37.89 & 44.68 & 49.45 & 51.86 & 52.27 & 51.39 & 51.04 & 52.33 & 81.08 & 125.62 \\
\hline CNG Bi-fuel & 0.00 & 0.00 & 0.00 & 0.00 & 0.00 & 0.00 & 0.00 & 0.00 & 0.00 & 0.00 \\
\hline LPG & 15.98 & 18.29 & 19.94 & 20.78 & 20.95 & 20.57 & 20.45 & 20.96 & 28.51 & 38.77 \\
\hline LPG Bi-fuel & 0.00 & 0.00 & 0.00 & 0.00 & 0.00 & 0.00 & 0.00 & 0.00 & 0.00 & 0.00 \\
\hline Electric & 1.06 & 1.24 & 1.33 & 1.34 & 1.29 & 0.96 & 0.94 & 0.98 & 1.37 & 1.93 \\
\hline Fuel Cell Gasoline & 0.00 & 0.00 & 0.00 & 0.00 & 0.00 & 0.00 & 0.00 & 0.00 & 0.00 & 0.00 \\
\hline Fuel Cell Methanol & 0.00 & 0.00 & 0.00 & 0.00 & 0.00 & 0.00 & 0.00 & 0.00 & 0.00 & 0.00 \\
\hline Fuel Cell Hydrogen & 0.00 & 0.00 & 0.00 & 0.00 & 0.00 & 0.00 & 0.00 & 0.00 & 0.00 & 0.00 \\
\hline Total Fleet Cars & 987.73 & 945.51 & 934.38 & 930.62 & 929.51 & 900.77 & 908.73 & 925.89 & 887.88 & 851.43 \\
\hline \multicolumn{11}{|l|}{ Light Trucks 1/ } \\
\hline Gasoline Conventional & 1671.40 & 1648.07 & 1637.24 & 1653.30 & 1673.73 & 1718.31 & 1759.42 & 1771.87 & 1808.87 & 1846.65 \\
\hline Distillate & 0.00 & 0.00 & 0.00 & 0.00 & 0.00 & 0.00 & 0.00 & 0.00 & 0.00 & 0.00 \\
\hline \multicolumn{11}{|l|}{ Methanol } \\
\hline Flex & 0.00 & 0.00 & 0.00 & 0.00 & 0.00 & 0.00 & 0.00 & 0.00 & 0.00 & 0.00 \\
\hline Neat & 3.69 & 4.52 & 5.29 & 5.91 & 6.26 & 6.45 & 6.56 & 6.62 & 11.10 & 18.60 \\
\hline \multicolumn{11}{|l|}{ Ethanol } \\
\hline Flex & 0.00 & 0.00 & 0.00 & 0.00 & 0.00 & 0.00 & 0.00 & 0.00 & 0.00 & 0.00 \\
\hline Neat & 0.51 & 0.63 & 0.74 & 0.83 & 0.88 & 0.90 & 0.92 & 0.93 & 1.56 & 2.63 \\
\hline CNG & 49.16 & 59.28 & 68.43 & 75.47 & 79.44 & 81.87 & 83.91 & 85.14 & 140.70 & 232.53 \\
\hline CNG Bi-fuel & 0.00 & 0.00 & 0.00 & 0.00 & 0.00 & 0.00 & 0.00 & 0.00 & 0.00 & 0.00 \\
\hline Electric & 0.58 & 0.66 & 0.70 & 0.71 & 0.68 & 0.54 & 0.57 & 0.61 & 0.85 & 1.20 \\
\hline Electric-Diesel Hybrid & 0.00 & 0.00 & 0.00 & 0.00 & 0.00 & 0.00 & 0.00 & 0.00 & 0.00 & 0.00 \\
\hline \multicolumn{11}{|l|}{ Fuel Cell } \\
\hline Fuel Cell Gasoline & 0.00 & 0.00 & 0.00 & 0.00 & 0.00 & 0.00 & 0.00 & 0.00 & 0.00 & 0.00 \\
\hline Fuel Cell Methanol & 0.00 & 0.00 & 0.00 & 0.00 & 0.00 & 0.00 & 0.00 & 0.00 & 0.00 & 0.00 \\
\hline Fuel Cell Hydrogen & 0.00 & 0.00 & 0.00 & 0.00 & 0.00 & 0.00 & 0.00 & 0.00 & 0.00 & 0.00 \\
\hline Total Fleet Light Trucks & 1745.32 & 1736.15 & 1738.10 & 1764.05 & 1790.04 & 1837.95 & 1881.97 & 1896.15 & 1961.03 & 2028.14 \\
\hline Total Fleet Vehicles & 2733.04 & 2681.66 & 2672.48 & 2694.67 & 2719.55 & 2738.72 & 2790.70 & 2822.04 & 2838.99 & 2856.04 \\
\hline Commercial Light Trucks 2/ & 642.33 & 652.28 & 662.80 & 673.12 & 681.61 & 714.04 & 757.35 & 793.22 & 841.13 & 891.93 \\
\hline
\end{tabular}

$1 /$ Includes all fleets of 10 or more.

2/ Commercial trucks from 8,500 to 10,000 pounds.

ICE = Internal combustion engine.

$\mathrm{CNG}=$ Compressed natural gas.

$\mathrm{LPG}=$ Liquid petroleum gas.

$\mathrm{N} / \mathrm{A}=$ Not Applicable.

Note: Totals may not equal sum of components due to independent rounding. The historical data used for the projections were the most available as of July 31, 1999. The numbers presented for 1998 are estimates and may differ from official EIA data reports. Also. please see EIA data publications and the Short-Term Energy Outlook for the latest estimates for 1999.

Sources: 1998 derived using: Oak Ridge National Laboratory, "Fleet Vehicles in the United States: Composition, Operating Characteristics, and Fueling Practices," prepared for the Department of Energy, Office of Transportation

Technologies, and Office of Policy, Planning, and Analysis, March 1992; Bobit Publishing Company, Fleet Fact Book, Redondo Beach, California, various issues; United States Department of Commerce, Bureau of the Census, "Trucks Inventory and Use Survey," TC92-T-52, (Washington, DC, May 1995); Federal Highway Administration,

Highway Statistics 1997 (November 1998); Decision Analysis Corporation of Virginia, NEMS Transportation Sector Model:

Development of the Light Commercial Truck Model, Final Report, Subtask 19-2, prepared for the Energy Information Administration (EIA) (April 23, 1997); and EIA AEO2000 National Energy Modeling System run AEO2K.D100199A.

Projections: EIA, AEO2000 National Energy Modeling System run AEO2K.D100199A. 
Table 52. Transportation Fleet Car and Truck Sales by Type and Technology (Thousands)

$\begin{array}{llllllllll}2002 & 2003 & 2004 & 2005 & 2006 & 2010 & 2015 & 2020 & 2025 & 2030\end{array}$

Cars 1/

Gasoline Conventional
Distillate
Methanol
Flex
Neat
Ethanol
Flex
Neat
CNG
CNG Bi-fuel
LPG
LPG Bi-fuel
Electric
Electric-Diesel Hybrid
Fuel Cell
Fuel Cell Gasoline
Fuel Cell Methanol
Fuel Cell Hydrogen
Total Fleet Cars

Light Trucks 1/

Gasoline Conventional
Distillate
Methanol
Flex
Neat
Ethanol
Flex
Neat
CNG
CNG Bi-fuel
LPG
LPG Bi-fuel
Electric
Electric-Diesel Hybrid
Fuel Cell
Fuel Cell Gasoline
Fuel Cell Methanol
Fuel Cell Hydrogen
Total Fleet Light Trucks

Total Fleet Vehicles

Commercial Light Trucks 2/

$\begin{array}{rrrrrrrrrr}1612.82 & 1630.48 & 1657.07 & 1676.42 & 1659.29 & 1653.99 & 1737.18 & 1730.56 & 1697.47 & 1665.00 \\ 0.00 & 0.00 & 0.00 & 0.00 & 0.00 & 0.00 & 0.00 & 0.00 & 0.00 & 0.00 \\ & & & & & & & & & \\ 0.00 & 0.00 & 0.00 & 0.00 & 0.00 & 0.00 & 0.00 & 0.00 & 0.00 & 0.00 \\ 14.37 & 14.52 & 14.76 & 14.93 & 14.78 & 14.73 & 15.47 & 15.42 & 20.22 & 26.52 \\ & & & & & & & & & \\ 0.00 & 0.00 & 0.00 & 0.00 & 0.00 & 0.00 & 0.00 & 0.00 & 0.00 & 0.00 \\ 1.68 & 1.70 & 1.73 & 1.75 & 1.73 & 1.72 & 1.81 & 1.80 & 2.43 & 3.27 \\ 76.79 & 77.63 & 78.89 & 79.81 & 79.00 & 78.75 & 82.71 & 82.39 & 102.45 & 127.39 \\ 0.00 & 0.00 & 0.00 & 0.00 & 0.00 & 0.00 & 0.00 & 0.00 & 0.00 & 0.00 \\ 31.10 & 31.44 & 31.96 & 32.33 & 32.00 & 31.90 & 33.50 & 33.37 & 39.15 & 45.93 \\ 0.00 & 0.00 & 0.00 & 0.00 & 0.00 & 0.00 & 0.00 & 0.00 & 0.00 & 0.00 \\ 2.19 & 2.22 & 2.25 & 2.28 & 2.26 & 2.25 & 2.36 & 2.35 & 2.80 & 3.34 \\ 0.00 & 0.00 & 0.00 & 0.00 & 0.00 & 0.00 & 0.00 & 0.00 & 0.00 & 0.00 \\ & & & & & & & & 0.00 & \\ 0.00 & 0.00 & 0.00 & 0.00 & 0.00 & 0.00 & 0.00 & 0.00 & 0.00 & 0.00 \\ 0.00 & 0.00 & 0.00 & 0.00 & 0.00 & 0.00 & 0.00 & 0.00 & 0.00 & 0.00 \\ 0.00 & 0.00 & 0.00 & 0.00 & 0.00 & 0.00 & 0.00 & 0.00 & 0.00 & 0.00 \\ 1738.95 & 1757.99 & 1786.66 & 1807.52 & 1789.05 & 1783.34 & 1873.03 & 1865.90 & 1849.81 & 1833.85\end{array}$

\begin{tabular}{|c|c|c|c|c|c|c|c|c|c|}
\hline $\begin{array}{r}1713.55 \\
0.00\end{array}$ & $\begin{array}{r}1767.44 \\
0.00\end{array}$ & $\begin{array}{r}1827.18 \\
0.00\end{array}$ & $\begin{array}{r}1875.56 \\
0.00\end{array}$ & $\begin{array}{r}1879.46 \\
0.00\end{array}$ & $\begin{array}{r}1937.37 \\
0.00\end{array}$ & $\begin{array}{r}2076.96 \\
0.00\end{array}$ & $\begin{array}{r}2088.09 \\
0.00\end{array}$ & $\begin{array}{r}2160.08 \\
0.00\end{array}$ & $\begin{array}{r}2234.55 \\
0.00\end{array}$ \\
\hline 0.00 & 0.00 & 0.00 & 0.00 & 0.00 & 0.00 & 0.00 & 0.00 & 0.00 & 0.00 \\
\hline 20.90 & 21.56 & 22.29 & 22.88 & 22.93 & 23.63 & 25.33 & 25.47 & 35.90 & 50.61 \\
\hline 0.00 & 0.00 & 0.00 & 0.00 & 0.00 & 0.00 & 0.00 & 0.00 & 0.00 & 0.00 \\
\hline 2.80 & 2.89 & 2.99 & 3.07 & 3.07 & 3.17 & 3.40 & 3.41 & 4.85 & 6.89 \\
\hline 68.15 & 70.30 & 72.67 & 74.60 & 74.75 & 77.06 & 82.61 & 83.05 & 113.96 & 156.37 \\
\hline 0.00 & 0.00 & 0.00 & 0.00 & 0.00 & 0.00 & 0.00 & 0.00 & 0.00 & 0.00 \\
\hline 25.04 & 25.83 & 26.70 & 27.41 & 27.46 & 28.31 & 30.35 & 30.51 & 38.38 & 48.27 \\
\hline 0.00 & 0.00 & 0.00 & 0.00 & 0.00 & 0.00 & 0.00 & 0.00 & 0.00 & 0.00 \\
\hline 0.87 & 0.89 & 0.92 & 0.95 & 0.95 & 0.98 & 1.05 & 1.06 & 1.33 & 1.68 \\
\hline 0.00 & 0.00 & 0.00 & 0.00 & 0.00 & 0.00 & 0.00 & 0.00 & 0.00 & 0.00 \\
\hline 0.00 & 0.00 & 0.00 & 0.00 & 0.00 & 0.00 & 0.00 & 0.00 & 0.00 & 0.00 \\
\hline 0.00 & 0.00 & 0.00 & 0.00 & 0.00 & 0.00 & 0.00 & 0.00 & 0.00 & 0.00 \\
\hline 0.00 & 0.00 & 0.00 & 0.00 & 0.00 & 0.00 & 0.00 & 0.00 & 0.00 & 0.00 \\
\hline 1831.31 & 1888.90 & 1952.75 & 2004.45 & 2008.62 & 2070.52 & 2219.69 & 2231.59 & 2332.41 & 2437.79 \\
\hline 3570.26 & 3646.90 & 3739.41 & 3811.97 & 3797.67 & 3853.86 & 4092.73 & 4097.49 & 4174.37 & 4252.71 \\
\hline 918.94 & 949.50 & 983.30 & 1010.75 & 1013.89 & 1049.26 & 1128.76 & 1135.92 & 1191.81 & 1250 \\
\hline
\end{tabular}

$1 /$ Includes all fleets of 10 or more.

2/ Commercial trucks from 8,500 to 10,000 pounds.

ICE = Internal combustion engine.

$\mathrm{CNG}=$ Compressed natural gas.

$L N G=$ Liquid petroleum gas.

$\mathrm{N} / \mathrm{A}=$ Not Applicable.

Note: Totals may not equal sum of components due to independent rounding. The historical data used for the projections were the most available as of July 31, 1999. The numbers presented for 1998 are estimates and may differ from official EIA data reports. Also. please see EIA data publications and the Short-Term Energy Outlook for the latest estimates for 1999.

Sources: 1998 derived using: Oak Ridge National Laboratory, "Fleet Vehicles in the United States: Composition,

Operating Characteristics, and Fueling Practices," prepared for the Department of Energy, Office of Transportation

Technologies, and Office of Policy, Planning, and Analysis, March 1992; Bobit Publishing Company, Fleet Fact Book, Redondo

Beach, California, various issues; United States Department of Commerce, Bureau of the Census, "Truck Inventory and Use

Survey," TC92-T-52, (Washington, DC, May 1995); Federal Highway Administration, Highway Statistics 1997

(November 1998); Decision Analysis Corporation of Virginia, NEMS Tramsportation Sector Model:Development of the Light

Commercial Truck Model, Final Report, Subtask 19-2, prepared for the Energy Information Administration (EIA)

(April 23, 1997); Energy Information Administration (EIA), Describing Current and Potential Markets for

Alternative-Fuel Vehicles, DOE/EIA-0604(96) (Washington, DC, March 1996); EIA, Alternatives to Traditional Transportation

Fuels 1996, DOE/EIA-0585(96) (Washington, DC, December 1997); and EIA, AEO2000 National Energy Modeling System run

AEO2K.D100199A. Projections: EIA, AEO2000 National Energy Modeling System run AEO2K.D100199A. 
Table 53. Transportation Fleet Car and Truck Stock by Type and Technology (Thousands)

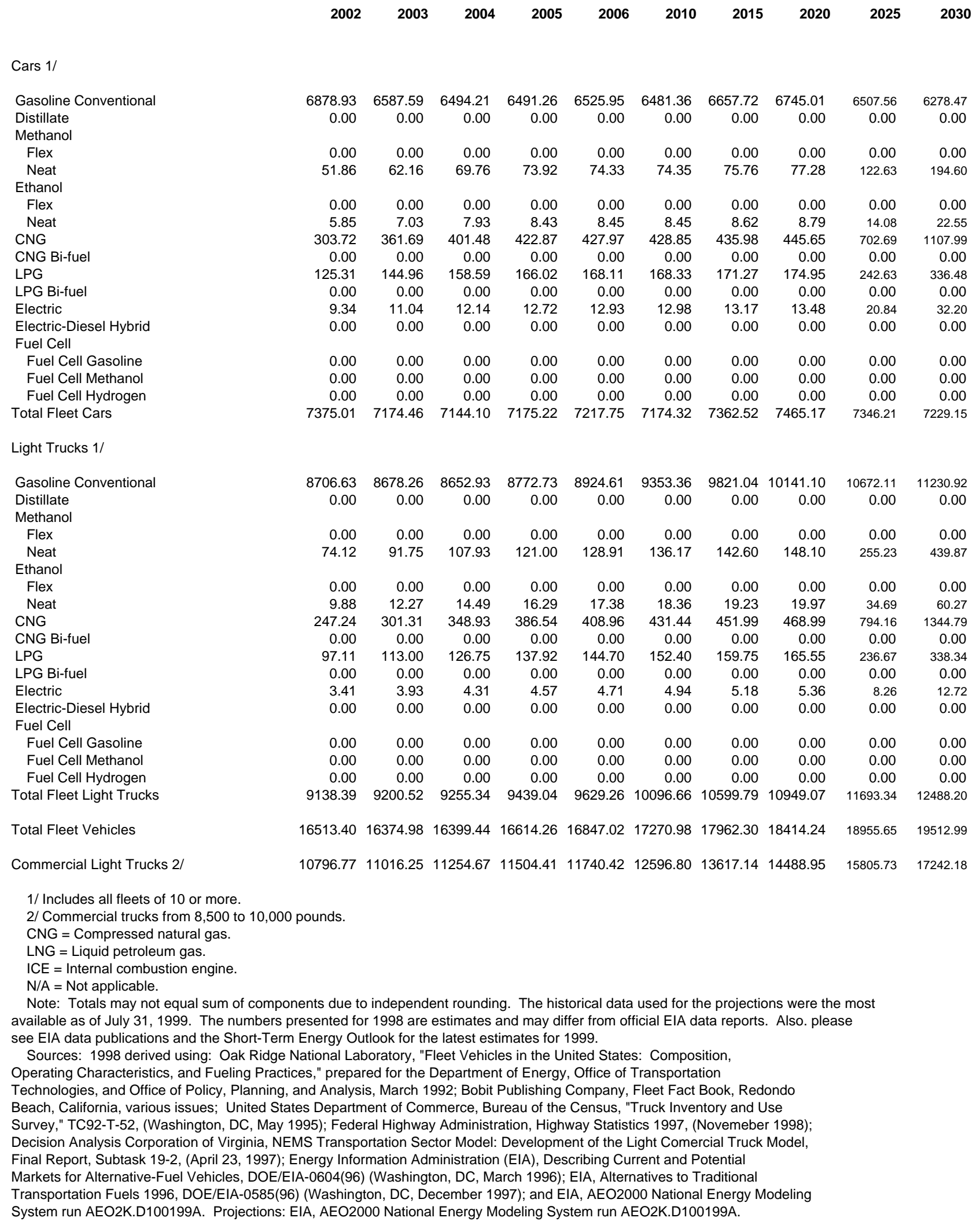


Table 54. Transportation Fleet Car and Truck VMT by Type and Technology (Billion Miles)

$\begin{array}{llllllllll}2002 & 2003 & 2004 & 2005 & 2006 & 2010 & 2015 & 2020 & 2025 & 2030\end{array}$

Cars 1/

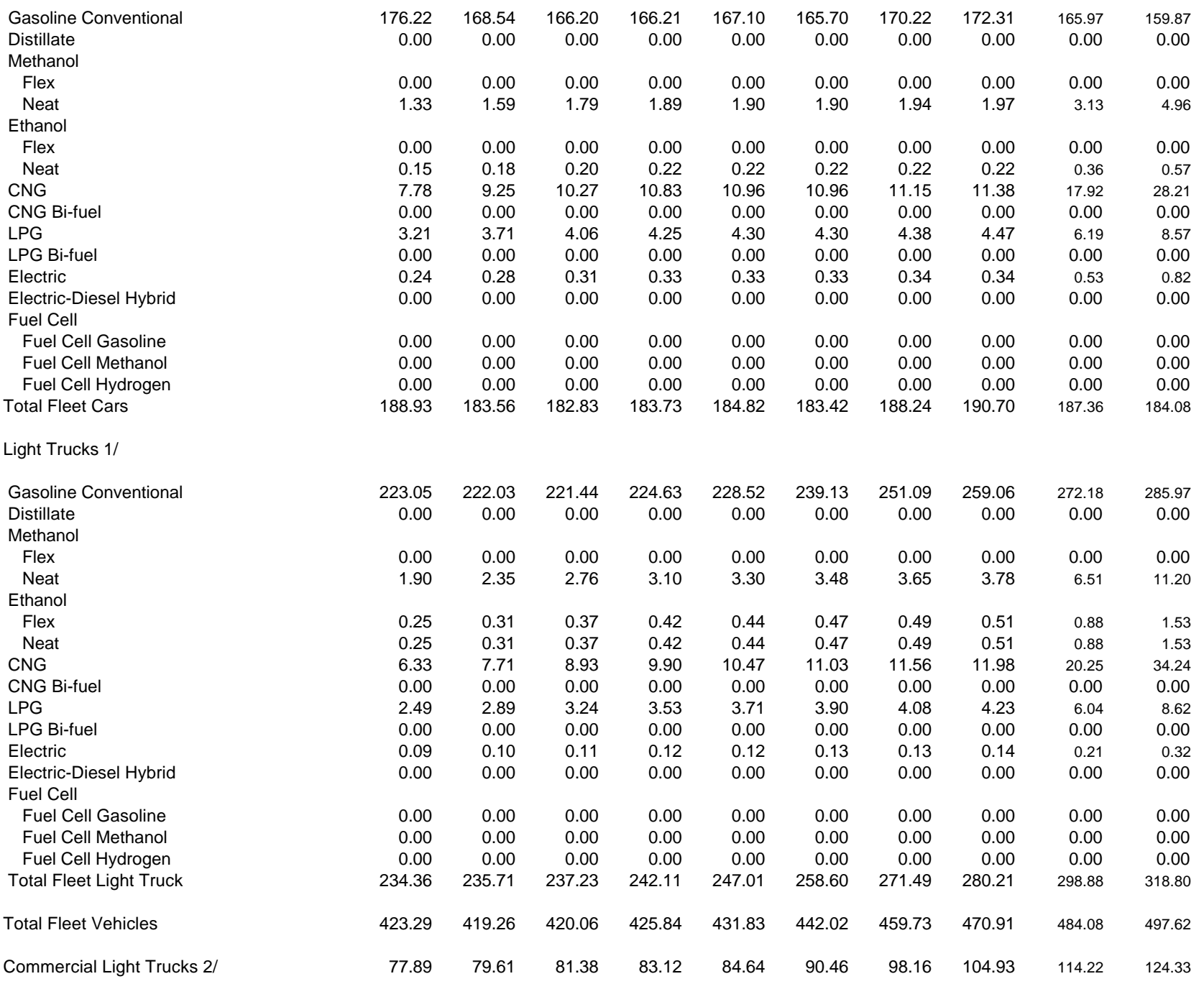

$1 /$ Includes all fleets of 10 or more.

2/ Commercial trucks from 8,500 to 10,000 pounds.

$\mathrm{CNG}=$ Compressed natural gas

LNG = Liquid petroleum gas

ICE = Internal combustion engine.

$\mathrm{N} / \mathrm{A}=$ Not applicable.

Note: Totals may not equal sum of components due to independent rounding. The historical data used for the projections were the most available as of July 31, 1999. The numbers presented for 1998 are estimates and may differ from official EIA data reports. Also. please see EIA data publications and the Short-Term Energy Outlook for the latest estimates for 1999.

Sources: 1998 derived using: Oak Ridge National Laboratory, "Fleet Vehicles in the

United States: Composition, Operating Characteristics, and Fueling Practices," prepared for the Department of Energy, Office

of Transportation Technologies, and Office of Policy, Planning, and Analysis, March 1992; Bobit Publishing Company, Fleet Fact

Book, Redondo Beach, California, various issues; Federal Highway Administration, Highway Statistics 1997, (Novemeber 1998);

Decision Analysis Corporation of Virginia, NEMS Transportation Sector Model: Development of the Light Comercial Truck Model,

Final Report, Subtask 19-2, (April 23, 1997); and Energy Information Administration (EIA), AEO2000 National Energy Modeling

System run AEO2K.D100199A. Projections: EIA, AEO2000 National Energy Modeling System run AEO2K.D100199A. 
Table 57. New Light-Duty Vehicle Fuel Economy (Miles per Gallon)

\begin{tabular}{|c|c|c|c|c|c|c|c|c|c|c|}
\hline & 2002 & 2003 & 2004 & 2005 & 2006 & 2010 & 2015 & 2020 & 2025 & 2030 \\
\hline \multicolumn{11}{|l|}{ Gasoline } \\
\hline Minincompact Cars & 27.00 & 27.75 & 27.75 & 28.02 & 28.36 & 29.37 & 29.69 & 29.81 & 30.72 & 31.66 \\
\hline Subcompact Cars & 32.62 & 33.26 & 33.25 & 33.30 & 33.46 & 34.07 & 33.99 & 33.66 & 34.09 & 34.53 \\
\hline Compact Cars & 31.61 & 32.50 & 32.46 & 32.53 & 32.72 & 33.54 & 33.62 & 33.39 & 34.04 & 34.71 \\
\hline Midsize Cars & 27.92 & 28.54 & 28.52 & 28.63 & 28.85 & 29.74 & 29.99 & 29.97 & 30.66 & 31.36 \\
\hline Large Cars & 25.30 & 26.03 & 26.03 & 26.17 & 26.40 & 27.51 & 28.11 & 28.29 & 29.19 & 30.12 \\
\hline 2-Seater Cars & 25.56 & 26.18 & 26.17 & 26.32 & 26.56 & 27.30 & 27.44 & 27.39 & 28.00 & 28.64 \\
\hline Small Pickup & 24.16 & 24.32 & 24.22 & 24.14 & 24.17 & 24.22 & 24.68 & 24.99 & 25.28 & 25.57 \\
\hline Large Pickup & 18.48 & 18.60 & 18.51 & 18.57 & 18.74 & 19.13 & 19.88 & 20.47 & 20.95 & 21.43 \\
\hline Small Van & 25.17 & 25.48 & 25.45 & 25.49 & 25.63 & 25.71 & 26.26 & 26.84 & 27.40 & 27.98 \\
\hline Large Van & 19.19 & 19.51 & 19.49 & 19.66 & 19.94 & 20.60 & 21.50 & 22.26 & 23.24 & 24.27 \\
\hline Small Utility & 21.76 & 22.06 & 22.01 & 22.03 & 22.18 & 22.56 & 23.20 & 23.57 & 24.17 & 24.80 \\
\hline Large Utility & 14.79 & 14.99 & 15.00 & 15.13 & 15.34 & 15.89 & 16.51 & 16.98 & 16.94 & 16.90 \\
\hline \multicolumn{11}{|c|}{ Turbo Direct Injection Diesel } \\
\hline Minincompact Cars & 0.00 & 0.00 & 0.00 & 0.00 & 0.00 & 0.00 & 0.00 & 0.00 & 0.00 & 0.00 \\
\hline Subcompact Cars & 0.00 & 0.00 & 0.00 & 0.00 & 0.00 & 0.00 & 0.00 & 0.00 & 0.00 & 0.00 \\
\hline Compact Cars & 40.67 & 41.20 & 41.11 & 41.17 & 41.34 & 42.05 & 41.94 & 41.44 & 41.81 & 42.19 \\
\hline Midsize Cars & 38.56 & 39.01 & 38.92 & 39.06 & 39.30 & 40.25 & 40.42 & 40.16 & 40.75 & 41.36 \\
\hline Large Cars & 36.05 & 36.85 & 36.83 & 37.00 & 37.26 & 38.48 & 39.28 & 39.50 & 40.51 & 41.53 \\
\hline 2-Seater Cars & 0.00 & 0.00 & 0.00 & 0.00 & 0.00 & 0.00 & 0.00 & 0.00 & 0.00 & 0.00 \\
\hline Small Pickup & 33.23 & 33.48 & 33.36 & 33.28 & 33.34 & 33.40 & 33.72 & 33.83 & 34.13 & 34.43 \\
\hline Large Pickup & 24.18 & 24.28 & 24.16 & 24.26 & 24.47 & 24.79 & 25.65 & 26.32 & 26.87 & 27.44 \\
\hline Small Van & 30.13 & 30.47 & 30.38 & 30.37 & 30.52 & 30.76 & 31.28 & 31.50 & 31.99 & 32.49 \\
\hline Large Van & 24.43 & 24.80 & 24.79 & 25.01 & 25.35 & 25.96 & 26.93 & 27.77 & 28.85 & 29.98 \\
\hline Small Utility & 28.13 & 28.48 & 28.39 & 28.41 & 28.58 & 28.92 & 29.52 & 29.83 & 30.43 & 31.05 \\
\hline Large Utility & 21.92 & 22.19 & 22.18 & 22.38 & 22.68 & 23.21 & 24.00 & 24.60 & 25.44 & 26.31 \\
\hline \multicolumn{11}{|l|}{ Methanol } \\
\hline Minincompact Cars & 0.00 & 0.00 & 0.00 & 0.00 & 0.00 & 0.00 & 0.00 & 0.00 & 0.00 & 0.00 \\
\hline Subcompact Cars & 39.15 & 39.74 & 39.68 & 39.71 & 39.85 & 40.52 & 40.39 & 39.94 & 40.31 & 40.67 \\
\hline Compact Cars & 32.63 & 33.42 & 33.34 & 33.38 & 33.55 & 34.22 & 34.17 & 33.85 & 34.32 & 34.80 \\
\hline Midsize Cars & 30.95 & 31.56 & 31.52 & 31.63 & 31.87 & 32.72 & 32.86 & 32.74 & 33.37 & 34.01 \\
\hline Large Cars & 28.95 & 29.77 & 29.77 & 29.91 & 30.15 & 31.33 & 32.01 & 32.17 & 33.12 & 34.09 \\
\hline 2-Seater Cars & 32.13 & 33.05 & 33.15 & 33.53 & 33.99 & 35.47 & 36.18 & 36.53 & 37.94 & 39.40 \\
\hline Small Pickup & 26.60 & 26.84 & 26.74 & 26.66 & 26.71 & 26.87 & 27.32 & 27.49 & 27.83 & 28.17 \\
\hline Large Pickup & 19.38 & 19.49 & 19.39 & 19.47 & 19.64 & 20.01 & 20.78 & 21.38 & 21.89 & 22.42 \\
\hline Small Van & 24.14 & 24.45 & 24.37 & 24.36 & 24.48 & 24.80 & 25.38 & 25.62 & 26.11 & 26.61 \\
\hline Large Van & 19.60 & 19.92 & 19.90 & 20.07 & 20.36 & 20.96 & 21.86 & 22.61 & 23.58 & 24.58 \\
\hline Small Utility & 0.00 & 0.00 & 0.00 & 0.00 & 0.00 & 0.00 & 0.00 & 0.00 & 0.00 & 0.00 \\
\hline Large Utility & 0.00 & 0.00 & 0.00 & 0.00 & 0.00 & 0.00 & 0.00 & 0.00 & 0.00 & 0.00 \\
\hline \multicolumn{11}{|l|}{ Methanol Flex } \\
\hline Minincompact Cars & 0.00 & 0.00 & 0.00 & 0.00 & 0.00 & 0.00 & 0.00 & 0.00 & 0.00 & 0.00 \\
\hline Subcompact Cars & 37.00 & 37.66 & 37.59 & 37.61 & 37.76 & 38.42 & 38.30 & 37.89 & 38.28 & 38.68 \\
\hline Compact Cars & 30.85 & 31.67 & 31.60 & 31.64 & 31.81 & 32.47 & 32.43 & 32.12 & 32.60 & 33.09 \\
\hline Midsize Cars & 29.26 & 29.89 & 29.84 & 29.96 & 30.18 & 31.01 & 31.17 & 31.08 & 31.71 & 32.36 \\
\hline Large Cars & 27.41 & 28.18 & 28.19 & 28.31 & 28.55 & 29.70 & 30.35 & 30.52 & 31.45 & 32.41 \\
\hline 2-Seater Cars & 30.37 & 31.31 & 31.40 & 31.76 & 32.21 & 33.62 & 34.33 & 34.66 & 36.04 & 37.46 \\
\hline Small Pickup & 25.13 & 25.35 & 25.25 & 25.18 & 25.23 & 25.42 & 25.89 & 26.06 & 26.40 & 26.75 \\
\hline Large Pickup & 18.31 & 18.42 & 18.32 & 18.39 & 18.56 & 18.94 & 19.68 & 20.26 & 20.76 & 21.28 \\
\hline Small Van & 22.81 & 23.11 & 23.03 & 23.02 & 23.14 & 23.47 & 24.07 & 24.30 & 24.79 & 25.29 \\
\hline Large Van & 18.52 & 18.83 & 18.81 & 18.97 & 19.25 & 19.87 & 20.73 & 21.46 & 22.40 & 23.38 \\
\hline Small Utility & 21.30 & 21.60 & 21.53 & 21.54 & 21.68 & 22.08 & 22.73 & 23.03 & 23.60 & 24.19 \\
\hline Large Utility & 16.62 & 16.84 & 16.84 & 16.99 & 17.23 & 17.83 & 18.53 & 19.05 & 19.80 & 20.59 \\
\hline \multicolumn{11}{|l|}{ Ethanol } \\
\hline Minincompact Cars & 0.00 & 0.00 & 0.00 & 0.00 & 0.00 & 0.00 & 0.00 & 0.00 & 0.00 & 0.00 \\
\hline Subcompact Cars & 37.73 & 38.36 & 38.30 & 38.32 & 38.46 & 39.12 & 39.01 & 38.59 & 38.97 & 39.36 \\
\hline Compact Cars & 31.44 & 32.26 & 32.19 & 32.22 & 32.39 & 33.06 & 33.02 & 32.70 & 33.18 & 33.67 \\
\hline Midsize Cars & 29.83 & 30.45 & 30.41 & 30.52 & 30.75 & 31.58 & 31.74 & 31.64 & 32.27 & 32.91 \\
\hline Large Cars & 27.93 & 28.71 & 28.72 & 28.85 & 29.08 & 30.25 & 30.90 & 31.08 & 32.01 & 32.97 \\
\hline 2-Seater Cars & 30.96 & 31.89 & 31.98 & 32.35 & 32.80 & 34.23 & 34.95 & 35.29 & 36.67 & 38.11 \\
\hline Small Pickup & 25.62 & 25.85 & 25.75 & 25.68 & 25.73 & 25.91 & 26.37 & 26.54 & 26.88 & 27.23 \\
\hline Large Pickup & 18.67 & 18.78 & 18.68 & 18.75 & 18.92 & 19.30 & 20.05 & 20.63 & 21.14 & 21.66 \\
\hline
\end{tabular}


Table 57. New Light-Duty Vehicle Fuel Economy (Miles per Gallon)

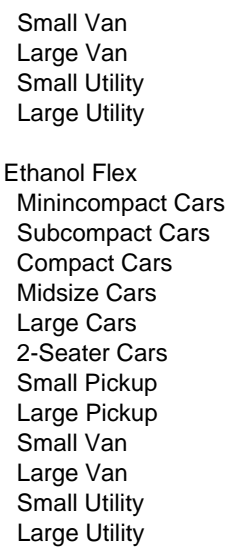

$\begin{array}{rrrrrrrrrr}\mathbf{2 0 0 2} & \mathbf{2 0 0 3} & \mathbf{2 0 0 4} & \mathbf{2 0 0 5} & \mathbf{2 0 0 6} & \mathbf{2 0 1 0} & \mathbf{2 0 1 5} & \mathbf{2 0 2 0} & \mathbf{2 0 2 5} & \mathbf{2 0 3 0} \\ 23.25 & 23.56 & 23.48 & 23.47 & 23.59 & 23.91 & 24.51 & 24.74 & 25.23 & 25.74 \\ 18.88 & 19.20 & 19.18 & 19.34 & 19.62 & 20.23 & 21.11 & 21.84 & 22.79 & 23.78 \\ 0.00 & 0.00 & 0.00 & 0.00 & 0.00 & 0.00 & 0.00 & 0.00 & 0.00 & 0.00 \\ 0.00 & 0.00 & 0.00 & 0.00 & 0.00 & 0.00 & 0.00 & 0.00 & 0.00 & 0.00 \\ & & & & & & & & & \\ 0.00 & 0.00 & 0.00 & 0.00 & 0.00 & 0.00 & 0.00 & 0.00 & 0.00 & 0.00 \\ 36.65 & 37.31 & 37.25 & 37.27 & 37.41 & 38.07 & 37.96 & 37.55 & 37.95 & 38.34 \\ 30.55 & 31.38 & 31.31 & 31.35 & 31.52 & 32.18 & 32.14 & 31.83 & 32.32 & 32.81 \\ 28.98 & 29.61 & 29.57 & 29.68 & 29.90 & 30.73 & 30.89 & 30.80 & 31.43 & 32.08 \\ 27.15 & 27.92 & 27.92 & 28.05 & 28.28 & 29.43 & 30.07 & 30.25 & 31.17 & 32.13 \\ 30.08 & 31.02 & 31.11 & 31.47 & 31.91 & 33.31 & 34.03 & 34.35 & 35.72 & 37.14 \\ 24.88 & 25.11 & 25.01 & 24.94 & 24.99 & 25.18 & 25.65 & 25.82 & 26.16 & 26.51 \\ 18.13 & 18.24 & 18.15 & 18.22 & 18.38 & 18.76 & 19.50 & 20.07 & 20.57 & 21.09 \\ 22.59 & 22.88 & 22.81 & 22.80 & 22.91 & 23.25 & 23.85 & 24.08 & 24.57 & 25.08 \\ 18.34 & 18.65 & 18.63 & 18.79 & 19.06 & 19.69 & 20.54 & 21.26 & 22.20 & 23.18 \\ 21.09 & 21.39 & 21.32 & 21.34 & 21.47 & 21.88 & 22.52 & 22.82 & 23.40 & 23.98 \\ 16.46 & 16.68 & 16.68 & 16.83 & 17.06 & 17.67 & 18.36 & 18.88 & 19.63 & 20.41\end{array}$

\begin{tabular}{|c|c|c|c|c|c|c|c|c|c|}
\hline 0.00 & 0.00 & 0.00 & 0.00 & 0.00 & 0.00 & 0.00 & 0.00 & 0.00 & 0.00 \\
\hline 0.00 & 0.00 & 0.00 & 0.00 & 0.00 & 0.00 & 0.00 & 0.00 & 0.00 & 0.00 \\
\hline 32.28 & 32.86 & 32.75 & 32.82 & 32.94 & 33.61 & 33.83 & 33.45 & 33.87 & 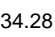 \\
\hline 30.69 & 31.10 & 31.02 & 31.15 & 31.33 & 32.18 & 32.62 & 32.46 & 33.04 & 33.6 \\
\hline 28.81 & 29.47 & 29.45 & 29.59 & 29.78 & 30.73 & 31.86 & 31.97 & 32.88 & \\
\hline 32.07 & 32.97 & 33.06 & 33.45 & 33.91 & 35.37 & 36.08 & 36.42 & 37.81 & 9 \\
\hline 26.46 & 26.68 & 26.55 & 26.47 & 26.52 & 26.53 & 26.75 & 27.10 & 27.37 & 27. \\
\hline 19.35 & 19.45 & 19.34 & 19.42 & 19.58 & 19.89 & 20.50 & 21.09 & 21.54 & 22. \\
\hline 24.06 & 24.36 & 24.27 & 24.25 & 24.37 & 24.56 & 24.94 & 25.33 & 25.76 & 26. \\
\hline 19.57 & 19.89 & 19.86 & 20.03 & 20.32 & 20.85 & 21.58 & 22.32 & 23.21 & \\
\hline 0.00 & 0.00 & 0.00 & 0.00 & 0.00 & 0.00 & 0.00 & 0.00 & 0.00 & 0.0 \\
\hline 0.00 & 0.00 & 0.00 & 0.00 & 0.00 & 0.00 & 0.00 & 0.00 & 0.00 & 0.0 \\
\hline
\end{tabular}

$\begin{array}{rrrrrrrrrr}0.00 & 0.00 & 0.00 & 0.00 & 0.00 & 0.00 & 0.00 & 0.00 & 0.00 & 0.00 \\ 0.00 & 0.00 & 0.00 & 0.00 & 0.00 & 0.00 & 0.00 & 0.00 & 0.00 & 0.00 \\ 29.94 & 30.56 & 30.46 & 30.51 & 30.64 & 31.28 & 31.51 & 31.17 & 31.60 & 32.04 \\ 28.47 & 28.90 & 28.84 & 28.96 & 29.14 & 29.94 & 30.38 & 30.25 & 30.83 & 31.43 \\ 26.78 & 27.38 & 27.36 & 27.49 & 27.68 & 28.61 & 29.64 & 29.77 & 30.65 & 31.56 \\ 29.73 & 30.64 & 30.73 & 31.08 & 31.52 & 32.89 & 33.60 & 33.92 & 35.26 & 36.65 \\ 24.52 & 24.73 & 24.61 & 24.54 & 24.58 & 24.63 & 24.89 & 25.23 & 25.50 & 25.78 \\ 17.93 & 18.03 & 17.93 & 18.00 & 18.15 & 18.47 & 19.06 & 19.63 & 20.06 & 20.50 \\ 22.31 & 22.59 & 22.51 & 22.49 & 22.60 & 22.81 & 23.22 & 23.59 & 24.02 & 24.46 \\ 18.15 & 18.44 & 18.42 & 18.57 & 18.84 & 19.40 & 20.10 & 20.80 & 21.66 & 22.55 \\ 0.00 & 0.00 & 0.00 & 0.00 & 0.00 & 0.00 & 0.00 & 0.00 & 0.00 & 0.00 \\ 0.00 & 0.00 & 0.00 & 0.00 & 0.00 & 0.00 & 0.00 & 0.00 & 0.00 & 0.00\end{array}$

$\begin{array}{rrrrrrrrrr}0.00 & 0.00 & 0.00 & 0.00 & 0.00 & 0.00 & 0.00 & 0.00 & 0.00 & 0.00 \\ 37.33 & 37.77 & 37.68 & 37.73 & 37.83 & 38.48 & 38.69 & 38.21 & 38.54 & 38.88 \\ 31.20 & 31.83 & 31.73 & 31.79 & 31.91 & 32.60 & 32.85 & 32.49 & 32.93 & 33.39 \\ 29.62 & 30.06 & 29.99 & 30.12 & 30.30 & 31.15 & 31.61 & 31.47 & 32.08 & 32.69 \\ 27.81 & 28.47 & 28.45 & 28.58 & 28.78 & 29.73 & 30.83 & 30.96 & 31.88 & 32.82 \\ 30.94 & 31.87 & 31.96 & 32.33 & 32.78 & 34.21 & 34.92 & 35.26 & 36.63 & 38.06 \\ 25.51 & 25.74 & 25.63 & 25.55 & 25.61 & 25.66 & 25.92 & 26.28 & 26.58 & 26.88 \\ 18.64 & 18.75 & 18.65 & 18.72 & 18.89 & 19.22 & 19.83 & 20.42 & 20.88 & 21.35 \\ 23.20 & 23.50 & 23.42 & 23.41 & 23.53 & 23.75 & 24.16 & 24.55 & 25.00 & 25.46 \\ 18.87 & 19.18 & 19.15 & 19.32 & 19.60 & 20.16 & 20.89 & 21.62 & 22.51 & 23.44 \\ 0.00 & 0.00 & 0.00 & 0.00 & 0.00 & 0.00 & 0.00 & 0.00 & 0.00 & 0.00 \\ 0.00 & 0.00 & 0.00 & 0.00 & 0.00 & 0.00 & 0.00 & 0.00 & 0.00 & 0.00\end{array}$

\begin{tabular}{|c|c|c|c|c|c|c|c|c|c|}
\hline 0.00 & 0.00 & 0.00 & 0.00 & 0.00 & 0.00 & 0.00 & 0.00 & 0.00 & 0.00 \\
\hline 0.00 & 0.00 & 0.00 & 0.00 & 0.00 & 0.00 & 0.00 & 0.00 & 0.00 & 0.00 \\
\hline 30.03 & 30.69 & 30.59 & 30.65 & 30.77 & 31.45 & 31.71 & 31.35 & 31.81 & 32.2 \\
\hline
\end{tabular}


Table 57. New Light-Duty Vehicle Fuel Economy (Miles per Gallon)

Midsize Cars
Large Cars
2-Seater Cars
Small Pickup
Large Pickup
Small Van
Large Van
Small Utility
Large Utility
Electric
Minincompact Cars
Subcompact Cars
Compact Cars
Midsize Cars
Large Cars
2-Seater Cars
Small Pickup
Large Pickup
Small Van
Large Van
Small Utility
Large Utility
Diesel-Electric Hybrid
Minincompact Cars
Subcompact Cars
Compact Cars
Midsize Cars
Large Cars
2-Seater Cars
Small Pickup
Large Pickup
Small Van
Large Van
Small Utility
Large Utility

Fuel Cell Methanol Minincompact Cars

Subcompact Cars

Compact Cars

Midsize Cars

Large Cars

2-Seater Cars

Small Pickup

Large Pickup

Small Van

Large Van

Small Utility

Large Utility

Fuel Cell Hydrogen

Minincompact Cars

Subcompact Cars

Compact Cars

Midsize Cars

Large Cars

2-Seater Cars

Small Pickup

Large Pickup

Small Van

Large Van

Small Utility

Large Utility

\begin{tabular}{|c|c|c|c|c|c|c|c|c|c|}
\hline 2002 & 2003 & 2004 & 2005 & 2006 & 2010 & 2015 & 2020 & 2025 & 2030 \\
\hline 28.52 & 28.99 & 28.92 & 29.05 & 29.23 & 30.06 & 30.51 & 30.39 & 31.00 & 31.62 \\
\hline 26.80 & 27.44 & 27.41 & 27.54 & 27.74 & 28.68 & 29.74 & 29.88 & 30.78 & 31.71 \\
\hline 29.78 & 30.71 & 30.80 & 31.15 & 31.59 & 32.97 & 33.69 & 34.02 & 35.37 & 36.78 \\
\hline 24.56 & 24.79 & 24.68 & 24.61 & 24.66 & 24.74 & 25.01 & 25.37 & 25.68 & 25.99 \\
\hline 17.94 & 18.05 & 17.95 & 18.02 & 18.18 & 18.51 & 19.12 & 19.70 & 20.15 & 20.62 \\
\hline 22.33 & 22.63 & 22.55 & 22.54 & 22.65 & 22.89 & 23.31 & 23.70 & 24.15 & 24.62 \\
\hline 18.16 & 18.46 & 18.44 & 18.60 & 18.86 & 19.44 & 20.15 & 20.87 & 21.75 & 22.66 \\
\hline 0.00 & 0.00 & 0.00 & 0.00 & 0.00 & 0.00 & 0.00 & 0.00 & 0.00 & 0.00 \\
\hline 0.00 & 0.00 & 0.00 & 0.00 & 0.00 & 0.00 & 0.00 & 0.00 & 0.00 & 0.00 \\
\hline 0.00 & 0.00 & 0.00 & 0.00 & 0.00 & 0.00 & 0.00 & 0.00 & 0.00 & 0.00 \\
\hline 34.87 & 37.92 & 41.17 & 45.50 & 51.02 & 57.38 & 56.44 & 55.75 & 61.57 & 68.00 \\
\hline 30.47 & 33.09 & 35.98 & 39.78 & 44.63 & 50.44 & 49.84 & 49.34 & 54.72 & 60.68 \\
\hline 0.00 & 0.00 & 0.00 & 0.00 & 0.00 & 0.00 & 0.00 & 0.00 & 0.00 & 0.00 \\
\hline 0.00 & 0.00 & 0.00 & 0.00 & 0.00 & 0.00 & 0.00 & 0.00 & 0.00 & 0.00 \\
\hline 28.43 & 30.86 & 33.53 & 37.03 & 41.51 & 46.73 & 46.05 & 45.59 & 50.40 & 55.73 \\
\hline 26.65 & 28.99 & 31.45 & 34.64 & 38.71 & 43.01 & 41.63 & 40.70 & 44.45 & 48.54 \\
\hline 0.00 & 0.00 & 0.00 & 0.00 & 0.00 & 0.00 & 0.00 & 0.00 & 0.00 & 0.00 \\
\hline 22.98 & 25.15 & 27.32 & 30.11 & 33.68 & 37.48 & 36.25 & 35.42 & 38.85 & 42.62 \\
\hline 0.00 & 0.00 & 0.00 & 0.00 & 0.00 & 0.00 & 0.00 & 0.00 & 0.00 & 0.00 \\
\hline 0.00 & 0.00 & 0.00 & 0.00 & 0.00 & 0.00 & 0.00 & 0.00 & 0.00 & 0.00 \\
\hline 0.00 & 0.00 & 0.00 & 0.00 & 0.00 & 0.00 & 0.00 & 0.00 & 0.00 & 0.00 \\
\hline 0.00 & 0.00 & 0.00 & 0.00 & 0.00 & 0.00 & 0.00 & 0.00 & 0.00 & 0.00 \\
\hline 61.55 & 61.91 & 61.07 & 60.53 & 60.28 & 60.97 & 61.37 & 61.55 & 61.49 & 61.43 \\
\hline 51.14 & 51.53 & 50.80 & 50.38 & 50.21 & 50.91 & 51.36 & 51.60 & 51.68 & 51.76 \\
\hline 48.03 & 48.35 & 47.72 & 47.45 & 47.41 & 48.56 & 49.48 & 50.05 & 50.50 & 50.96 \\
\hline 44.46 & 44.94 & 44.41 & 44.23 & 44.30 & 45.90 & 47.33 & 48.41 & 49.33 & 50.27 \\
\hline 46.61 & 46.99 & 46.52 & 46.49 & 46.70 & 48.85 & 50.92 & 52.45 & 53.85 & 55.29 \\
\hline 0.00 & 0.00 & 0.00 & 0.00 & 0.00 & 0.00 & 0.00 & 0.00 & 0.00 & 0.00 \\
\hline 0.00 & 0.00 & 0.00 & 0.00 & 0.00 & 0.00 & 0.00 & 0.00 & 0.00 & 0.00 \\
\hline 38.03 & 38.61 & 38.28 & 38.18 & 38.33 & 38.68 & 38.80 & 38.90 & 39.33 & 39.78 \\
\hline 0.00 & 0.00 & 0.00 & 0.00 & 0.00 & 0.00 & 0.00 & 0.00 & 0.00 & 0.00 \\
\hline 35.61 & 36.19 & 35.93 & 35.91 & 36.15 & 36.77 & 37.21 & 37.50 & 38.23 & 38.97 \\
\hline 28.75 & 29.20 & 29.01 & 29.05 & 29.28 & 29.91 & 30.54 & 30.96 & 31.75 & 32.56 \\
\hline
\end{tabular}

$\begin{array}{rrrrrrrrrr}0.00 & 0.00 & 0.00 & 0.00 & 0.00 & 0.00 & 0.00 & 0.00 & 0.00 & 0.00 \\ 0.00 & 0.00 & 0.00 & 0.00 & 0.00 & 0.00 & 0.00 & 0.00 & 0.00 & 0.00 \\ 53.73 & 53.42 & 52.71 & 52.34 & 52.06 & 51.30 & 50.69 & 50.18 & 49.11 & 48.06 \\ 46.74 & 46.66 & 46.07 & 45.75 & 45.51 & 44.90 & 44.57 & 44.21 & 43.39 & 42.59 \\ 42.04 & 41.70 & 41.22 & 40.97 & 40.78 & 40.10 & 39.55 & 39.26 & 38.41 & 37.58 \\ 50.14 & 49.82 & 49.12 & 48.72 & 48.42 & 47.53 & 46.83 & 46.37 & 45.24 & 44.13 \\ 47.00 & 46.80 & 46.08 & 45.57 & 45.15 & 43.74 & 42.34 & 41.40 & 39.89 & 38.44 \\ 0.00 & 0.00 & 0.00 & 0.00 & 0.00 & 0.00 & 0.00 & 0.00 & 0.00 & 0.00 \\ 40.53 & 40.59 & 40.03 & 39.62 & 39.28 & 38.12 & 36.86 & 36.03 & 34.87 & 33.75 \\ 0.00 & 0.00 & 0.00 & 0.00 & 0.00 & 0.00 & 0.00 & 0.00 & 0.00 & 0.00 \\ 0.00 & 0.00 & 0.00 & 0.00 & 0.00 & 0.00 & 0.00 & 0.00 & 0.00 & 0.00 \\ 0.00 & 0.00 & 0.00 & 0.00 & 0.00 & 0.00 & 0.00 & 0.00 & 0.00 & 0.00 \\ & & & & & & & & & \\ & & & & & & & & & \\ 0.00 & 0.00 & 0.00 & 0.00 & 0.00 & 0.00 & 0.00 & 0.00 & 0.00 & 0.00 \\ 0.00 & 0.00 & 0.00 & 0.00 & 0.00 & 0.00 & 0.00 & 0.00 & 0.00 & 0.00 \\ 58.92 & 58.57 & 57.80 & 57.39 & 57.08 & 56.25 & 55.58 & 55.02 & 53.85 & 52.69 \\ 51.25 & 51.16 & 50.51 & 50.16 & 49.90 & 49.23 & 48.87 & 48.48 & 47.58 & 46.70 \\ 46.10 & 45.72 & 45.19 & 44.92 & 44.71 & 43.97 & 43.36 & 43.05 & 42.12 & 41.20 \\ 54.98 & 54.62 & 53.86 & 53.43 & 53.09 & 52.11 & 51.35 & 50.84 & 49.60 & 48.39 \\ 0.00 & 0.00 & 0.00 & 0.00 & 0.00 & 0.00 & 0.00 & 0.00 & 0.00 & 0.00 \\ 0.00 & 0.00 & 0.00 & 0.00 & 0.00 & 0.00 & 0.00 & 0.00 & 0.00 & 0.00 \\ 44.44 & 44.51 & 43.89 & 43.44 & 43.07 & 41.79 & 40.42 & 39.50 & 38.23 & 37.01 \\ 0.00 & 0.00 & 0.00 & 0.00 & 0.00 & 0.00 & 0.00 & 0.00 & 0.00 & 0.00 \\ 0.00 & 0.00 & 0.00 & 0.00 & 0.00 & 0.00 & 0.00 & 0.00 & 0.00 & 0.00 \\ 0.00 & 0.00 & 0.00 & 0.00 & 0.00 & 0.00 & 0.00 & 0.00 & 0.00 & 0.00\end{array}$


Table 57. New Light-Duty Vehicle Fuel Economy (Miles per Gallon)

\begin{tabular}{|c|c|c|c|c|c|c|c|c|c|c|}
\hline & 2002 & 2003 & 2004 & 2005 & 2006 & 2010 & 2015 & 2020 & 2025 & 2030 \\
\hline \multicolumn{11}{|l|}{ Fuel Cell Gasoline } \\
\hline Minincompact Cars & 0.00 & 0.00 & 0.00 & 0.00 & 0.00 & 0.00 & 0.00 & 0.00 & 0.00 & 0.00 \\
\hline Subcompact Cars & 0.00 & 0.00 & 0.00 & 0.00 & 0.00 & 0.00 & 0.00 & 0.00 & 0.00 & 0.00 \\
\hline Compact Cars & 50.35 & 50.05 & 49.39 & 49.04 & 48.78 & 48.07 & 47.50 & 47.02 & 46.01 & 45.03 \\
\hline Midsize Cars & 43.80 & 43.72 & 43.17 & 42.87 & 42.65 & 42.07 & 41.76 & 41.43 & 40.66 & 39.91 \\
\hline Large Cars & 39.40 & 39.07 & 38.62 & 38.39 & 38.21 & 37.57 & 37.06 & 36.79 & 35.99 & 35.21 \\
\hline 2-Seater Cars & 46.98 & 46.68 & 46.03 & 45.66 & 45.37 & 44.54 & 43.88 & 43.45 & 42.39 & 41.35 \\
\hline Large Pickup & 0.00 & 0.00 & 0.00 & 0.00 & 0.00 & 0.00 & 0.00 & 0.00 & 0.00 & 0.00 \\
\hline Small Van & 37.98 & 38.04 & 37.50 & 37.12 & 36.81 & 35.72 & 34.54 & 33.76 & 32.67 & 31.63 \\
\hline Large Van & 0.00 & 0.00 & 0.00 & 0.00 & 0.00 & 0.00 & 0.00 & 0.00 & 0.00 & 0.00 \\
\hline Small Utility & 0.00 & 0.00 & 0.00 & 0.00 & 0.00 & 0.00 & 0.00 & 0.00 & 0.00 & 0.00 \\
\hline Large Utility & 0.00 & 0.00 & 0.00 & 0.00 & 0.00 & 0.00 & 0.00 & 0.00 & 0.00 & 0.00 \\
\hline
\end{tabular}

$\mathrm{N} / \mathrm{A}=$ Not applicable

Note: The historical data used for the projections were the most available as of July 31, 1999. The numbers presented for 1998 are estimates and may differ from official EIA data reports. Also. please see EIA data publications and the Short-Term Energy Outlook for the latest estimates for 1999.

Sources: 1997 derived using: Energy and Environmental Analysis Inc., Updates to the Fuels Economy Model, prepared for Energy Information Administration (EIA)

(Washington, DC, June 1998); National Highway Traffic and Safety Administration,

Mid-Model Year Fuel Economy Reports for for Auto Manufacturers, 1998; and EIA,

AEO2000 National Energy Modeling System run AEO2K.D100199A. Projection: EIA,

AEO2000 National Energy Modeling System run AEO2K.D100199A. 
Table 58. New Light-Duty Vehicle Prices (Thousands 1990 Dollars)

\begin{tabular}{|c|c|c|c|c|c|c|c|c|c|c|}
\hline & 2002 & 2003 & 2004 & 2005 & 2006 & 2010 & 2015 & 2020 & 2025 & 2030 \\
\hline \multicolumn{11}{|l|}{ Gasoline } \\
\hline Minincompact Cars & 28.4 & 28.5 & 28.7 & 28.7 & 28.7 & 28.7 & 29.0 & 29.2 & 29.49 & 29.77 \\
\hline Subcompact Cars & 13.5 & 13.6 & 13.8 & 13.9 & 13.9 & 14.0 & 14.3 & 14.6 & 14.96 & 15.35 \\
\hline Compact Cars & 16.9 & 17.0 & 17.3 & 17.3 & 17.3 & 17.5 & 17.7 & 18.0 & 18.39 & 18.77 \\
\hline Midsize Cars & 19.2 & 19.2 & 19.5 & 19.5 & 19.6 & 19.6 & 19.8 & 20.0 & 20.33 & 20.66 \\
\hline Large Cars & 22.8 & 22.9 & 23.2 & 23.2 & 23.2 & 23.2 & 23.2 & 23.4 & 23.68 & 23.94 \\
\hline 2-Seater Cars & 21.1 & 21.1 & 21.4 & 21.4 & 21.5 & 21.5 & 21.7 & 22.0 & 22.33 & 22.65 \\
\hline Small Pickup & 13.4 & 13.4 & 13.7 & 13.7 & 13.7 & 13.7 & 13.9 & 14.2 & 14.41 & 14.67 \\
\hline Large Pickup & 16.3 & 16.3 & 16.6 & 16.6 & 16.6 & 16.5 & 16.5 & 16.7 & 16.79 & 16.92 \\
\hline Small Van & 19.1 & 19.2 & 19.5 & 19.5 & 19.5 & 19.5 & 19.6 & 19.9 & 20.16 & 20.45 \\
\hline Large Van & 16.7 & 16.8 & 17.1 & 17.0 & 17.0 & 16.9 & 16.8 & 17.0 & 17.15 & 17.28 \\
\hline Small Utility & 20.2 & 20.3 & 20.6 & 20.5 & 20.5 & 20.5 & 20.6 & 20.9 & 21.12 & 21.36 \\
\hline Large Utility & 19.0 & 19.0 & 19.2 & 19.2 & 19.2 & 19.2 & 19.2 & 19.4 & 19.50 & 19.65 \\
\hline \multicolumn{11}{|c|}{ Turbo Direct Injection Diesel } \\
\hline Minincompact Cars & 0.0 & 0.0 & 0.0 & 0.0 & 0.0 & 0.0 & 0.0 & 0.0 & 0.0 & 0.0 \\
\hline Subcompact Cars & 0.0 & 0.0 & 0.0 & 0.0 & 0.0 & 0.0 & 0.0 & 0.0 & 0.0 & 0.0 \\
\hline Compact Cars & 17.0 & 17.8 & 18.1 & 18.1 & 18.1 & 18.3 & 18.5 & 18.8 & 19.35 & 19.91 \\
\hline Midsize Cars & 20.2 & 20.1 & 20.2 & 20.1 & 20.2 & 20.0 & 20.2 & 20.4 & 20.57 & 20.73 \\
\hline Large Cars & 23.6 & 23.7 & 24.0 & 24.0 & 24.0 & 24.0 & 24.0 & 24.2 & 24.48 & 24.74 \\
\hline 2-Seater Cars & 0.0 & 0.0 & 0.0 & 0.0 & 0.0 & 0.0 & 0.0 & 0.0 & 0.0 & 0.0 \\
\hline Small Pickup & 15.0 & 15.0 & 15.1 & 15.0 & 15.2 & 15.1 & 15.2 & 15.5 & 15.73 & 15.95 \\
\hline Large Pickup & 18.8 & 18.7 & 18.8 & 18.6 & 19.1 & 19.0 & 18.9 & 19.1 & 19.22 & 19.34 \\
\hline Small Van & 21.0 & 21.0 & 21.1 & 21.0 & 21.2 & 21.2 & 21.4 & 21.7 & 21.93 & 22.20 \\
\hline Large Van & 19.1 & 19.2 & 19.5 & 19.4 & 19.4 & 19.3 & 19.2 & 19.3 & 19.44 & 19.55 \\
\hline Small Utility & 22.3 & 22.2 & 22.3 & 22.1 & 22.3 & 22.0 & 22.2 & 22.4 & 22.48 & 22.56 \\
\hline Large Utility & 24.7 & 24.6 & 24.7 & 24.5 & 25.0 & 24.9 & 24.9 & 25.1 & 25.22 & 25.37 \\
\hline \multicolumn{11}{|l|}{ Methanol } \\
\hline Minincompact Cars & 0.0 & 0.0 & 0.0 & 0.0 & 0.0 & 0.0 & 0.0 & 0.0 & 0.0 & 0.0 \\
\hline Subcompact Cars & 13.9 & 13.9 & 14.2 & 14.2 & 14.3 & 14.4 & 14.7 & 15.0 & 15.33 & 15.72 \\
\hline Compact Cars & 17.4 & 17.5 & 17.8 & 17.8 & 17.9 & 17.6 & 18.1 & 18.4 & 18.72 & 19.07 \\
\hline Midsize Cars & 20.1 & 20.2 & 20.5 & 20.5 & 20.5 & 20.3 & 20.1 & 20.4 & 20.63 & 20.82 \\
\hline Large Cars & 23.2 & 23.3 & 23.6 & 23.6 & 23.6 & 23.6 & 23.6 & 23.8 & 24.05 & 24.31 \\
\hline 2-Seater Cars & 21.5 & 21.5 & 21.8 & 21.8 & 21.8 & 21.9 & 22.1 & 22.4 & 22.70 & 23.02 \\
\hline Small Pickup & 14.9 & 14.9 & 15.2 & 15.1 & 15.1 & 15.2 & 15.4 & 15.7 & 15.93 & 16.21 \\
\hline Large Pickup & 18.2 & 18.3 & 18.5 & 18.5 & 18.5 & 18.4 & 18.4 & 18.6 & 18.73 & 18.87 \\
\hline Small Van & 20.9 & 20.9 & 21.2 & 21.1 & 21.1 & 21.2 & 21.3 & 21.6 & 21.91 & 22.20 \\
\hline Large Van & 18.6 & 18.6 & 18.9 & 18.9 & 18.8 & 18.7 & 18.7 & 18.8 & 18.96 & 19.08 \\
\hline Small Utility & 0.0 & 0.0 & 0.0 & 0.0 & 0.0 & 0.0 & 0.0 & 0.0 & 0.0 & 0.0 \\
\hline Large Utility & 0.0 & 0.0 & 0.0 & 0.0 & 0.0 & 0.0 & 0.0 & 0.0 & 0.0 & 0.0 \\
\hline \multicolumn{11}{|l|}{ Methanol Flex } \\
\hline Minincompact Cars & 0.0 & 0.0 & 0.0 & 0.0 & 0.0 & 0.0 & 0.0 & 0.0 & 0.0 & 0.0 \\
\hline Subcompact Cars & 13.9 & 14.0 & 14.2 & 14.3 & 14.3 & 14.4 & 14.7 & 15.0 & 15.37 & 15.76 \\
\hline Compact Cars & 17.3 & 17.4 & 17.7 & 17.7 & 17.8 & 17.9 & 18.1 & 18.4 & 18.79 & 19.18 \\
\hline Midsize Cars & 19.6 & 19.7 & 19.9 & 20.0 & 20.0 & 20.0 & 20.2 & 20.1 & 20.34 & 20.58 \\
\hline Large Cars & 23.2 & 23.3 & 23.6 & 23.6 & 23.6 & 23.6 & 23.6 & 23.8 & 24.09 & 24.35 \\
\hline 2-Seater Cars & 21.5 & 21.6 & 21.8 & 21.8 & 21.9 & 21.9 & 22.1 & 22.4 & 22.74 & 23.06 \\
\hline Small Pickup & 14.5 & 14.5 & 14.8 & 14.8 & 14.8 & 15.0 & 15.5 & 15.8 & 16.11 & 16.43 \\
\hline Large Pickup & 18.2 & 18.2 & 18.5 & 18.5 & 18.5 & 18.6 & 18.6 & 18.8 & 18.92 & 19.06 \\
\hline Small Van & 21.0 & 21.0 & 21.3 & 21.3 & 21.3 & 21.3 & 21.5 & 21.8 & 22.06 & 22.35 \\
\hline Large Van & 18.7 & 18.8 & 19.1 & 19.0 & 19.0 & 18.9 & 18.8 & 19.0 & 19.15 & 19.28 \\
\hline Small Utility & 21.3 & 21.3 & 21.6 & 21.6 & 21.5 & 21.6 & 21.7 & 22.2 & 22.41 & 22.62 \\
\hline Large Utility & 24.3 & 24.3 & 24.6 & 24.6 & 24.6 & 24.6 & 24.5 & 24.8 & 24.94 & 25.11 \\
\hline \multicolumn{11}{|l|}{ Ethanol } \\
\hline Minincompact Cars & 0.0 & 0.0 & 0.0 & 0.0 & 0.0 & 0.0 & 0.0 & 0.0 & 0.0 & 0.0 \\
\hline Subcompact Cars & 13.9 & 13.9 & 14.2 & 14.2 & 14.3 & 14.4 & 14.7 & 15.0 & 15.33 & 15.72 \\
\hline Compact Cars & 17.4 & 17.5 & 17.8 & 17.8 & 17.9 & 18.0 & 18.1 & 18.6 & 18.95 & 19.35 \\
\hline Midsize Cars & 20.1 & 20.2 & 20.5 & 20.5 & 20.5 & 20.6 & 20.6 & 20.9 & 21.26 & 21.58 \\
\hline Large Cars & 23.2 & 23.3 & 23.6 & 23.6 & 23.6 & 23.6 & 23.6 & 23.8 & 24.05 & 24.31 \\
\hline 2-Seater Cars & 21.5 & 21.5 & 21.8 & 21.8 & 21.8 & 21.9 & 22.1 & 22.4 & 22.70 & 23.02 \\
\hline Small Pickup & 14.9 & 14.9 & 15.2 & 15.1 & 15.1 & 15.2 & 15.4 & 15.7 & 15.93 & 16.21 \\
\hline Large Pickup & 18.2 & 18.3 & 18.5 & 18.5 & 18.5 & 18.4 & 18.4 & 18.6 & 18.74 & 18.87 \\
\hline
\end{tabular}


Table 58. New Light-Duty Vehicle Prices (Thousands 1990 Dollars)

Small Van
Large Van
Small Utility
Large Utility
Ethanol Flex
Minincompact Cars
Subcompact Cars
Compact Cars
Midsize Cars
Large Cars
2-Seater Cars
Small Pickup
Large Pickup
Small Van
Large Van
Small Utility
Large Utility

Compressed Natural Gas (CNG) Minincompact Cars

Subcompact Cars

Compact Cars

Midsize Cars

Large Cars

2-Seater Cars

Small Pickup

Large Pickup

Small Van

Large Van

Small Utility

Large Utility

CNG Bi-Fuel

Minincompact Cars

Subcompact Cars

Compact Cars

Midsize Cars

Large Cars

2-Seater Cars

Small Pickup

Large Pickup

Small Van

Large Van

Small Utility

Large Utility

Liquefied Petroleum Gas (LPG)

Minincompact Cars

Subcompact Cars

Compact Cars

Midsize Cars

Large Cars

2-Seater Cars

Small Pickup

Large Pickup

Small Van

Large Van

Small Utility

Large Utility

$\begin{array}{rrrrrrrrrr}\mathbf{2 0 0 2} & \mathbf{2 0 0 3} & \mathbf{2 0 0 4} & \mathbf{2 0 0 5} & \mathbf{2 0 0 6} & \mathbf{2 0 1 0} & \mathbf{2 0 1 5} & \mathbf{2 0 2 0} & \mathbf{2 0 2 5} & \mathbf{2 0 3 0} \\ & & & & & & & & & \\ 20.9 & 20.9 & 21.2 & 21.2 & 21.1 & 21.2 & 21.3 & 21.6 & 21.92 & 22.21 \\ 18.6 & 18.6 & 18.9 & 18.9 & 18.8 & 18.7 & 18.7 & 18.8 & 18.96 & 19.09 \\ 0.0 & 0.0 & 0.0 & 0.0 & 0.0 & 0.0 & 0.0 & 0.0 & 0.0 & 0.0 \\ 0.0 & 0.0 & 0.0 & 0.0 & 0.0 & 0.0 & 0.0 & 0.0 & 0.0 & 0.0\end{array}$

$\begin{array}{rrrrrrrrrr}0.0 & 0.0 & 0.0 & 0.0 & 0.0 & 0.0 & 0.0 & 0.0 & 0.0 & 0.0 \\ 13.9 & 14.0 & 14.2 & 14.3 & 14.3 & 14.4 & 14.7 & 15.0 & 15.37 & 15.76 \\ 17.3 & 17.4 & 17.7 & 17.7 & 17.8 & 17.9 & 18.1 & 18.4 & 18.79 & 19.18 \\ 19.6 & 19.7 & 19.9 & 20.0 & 20.0 & 19.7 & 20.0 & 20.4 & 20.75 & 21.13 \\ 23.2 & 23.3 & 23.6 & 23.6 & 23.6 & 23.6 & 23.6 & 23.8 & 24.09 & 24.35 \\ 21.5 & 21.6 & 21.8 & 21.8 & 21.9 & 21.9 & 22.1 & 22.4 & 22.74 & 23.06 \\ 14.6 & 14.6 & 14.9 & 14.8 & 14.9 & 15.1 & 15.5 & 15.8 & 16.09 & 16.38 \\ 18.3 & 18.3 & 18.6 & 18.6 & 18.6 & 18.6 & 18.6 & 18.8 & 18.92 & 19.06 \\ 21.0 & 21.0 & 21.3 & 21.3 & 21.3 & 21.3 & 21.5 & 21.8 & 22.06 & 22.35 \\ 18.7 & 18.8 & 19.1 & 19.0 & 19.0 & 18.9 & 18.8 & 19.0 & 19.15 & 19.28 \\ 21.6 & 21.6 & 21.8 & 21.8 & 21.8 & 21.8 & 22.1 & 22.6 & 22.86 & 23.09 \\ 24.3 & 24.3 & 24.6 & 24.6 & 24.6 & 24.6 & 24.5 & 24.8 & 24.94 & 25.12\end{array}$

$\begin{array}{rrrrrrrrrr}0.0 & 0.0 & 0.0 & 0.0 & 0.0 & 0.0 & 0.0 & 0.0 & 0.0 & 0.0 \\ 0.0 & 0.0 & 0.0 & 0.0 & 0.0 & 0.0 & 0.0 & 0.0 & 0.0 & 0.0 \\ 20.7 & 20.8 & 21.1 & 21.1 & 21.1 & 21.2 & 21.5 & 21.8 & 22.18 & 22.56 \\ 23.5 & 23.6 & 23.9 & 23.9 & 23.9 & 23.9 & 24.1 & 24.3 & 24.63 & 24.94 \\ 24.8 & 24.9 & 25.2 & 25.2 & 25.2 & 24.9 & 24.6 & 24.8 & 24.91 & 25.02 \\ 21.3 & 21.4 & 21.7 & 21.6 & 21.7 & 21.6 & 23.4 & 23.7 & 24.43 & 25.18 \\ 18.3 & 18.3 & 18.6 & 18.6 & 18.6 & 18.6 & 18.7 & 19.0 & 19.26 & 19.52 \\ 21.8 & 21.8 & 22.1 & 22.0 & 22.0 & 21.9 & 21.8 & 22.0 & 22.12 & 22.23 \\ 24.3 & 24.3 & 24.6 & 24.5 & 24.5 & 24.5 & 24.6 & 24.9 & 25.21 & 25.47 \\ 22.1 & 22.1 & 22.4 & 22.4 & 22.4 & 22.2 & 22.1 & 22.2 & 22.34 & 22.43 \\ 0.0 & 0.0 & 0.0 & 0.0 & 0.0 & 0.0 & 0.0 & 0.0 & 0.0 & 0.0 \\ 0.0 & 0.0 & 0.0 & 0.0 & 0.0 & 0.0 & 0.0 & 0.0 & 0.0 & 0.0\end{array}$

$\begin{array}{rrrrrrrrrr}0.0 & 0.0 & 0.0 & 0.0 & 0.0 & 0.0 & 0.0 & 0.0 & 0.0 & 0.0 \\ 0.0 & 0.0 & 0.0 & 0.0 & 0.0 & 0.0 & 0.0 & 0.0 & 0.0 & 0.0 \\ 21.7 & 21.8 & 22.1 & 22.1 & 22.1 & 22.2 & 22.5 & 22.8 & 23.18 & 23.56 \\ 24.5 & 24.6 & 24.9 & 24.9 & 24.9 & 24.9 & 25.1 & 25.3 & 25.63 & 25.94 \\ 25.8 & 25.9 & 26.2 & 26.2 & 26.2 & 25.9 & 25.6 & 25.8 & 25.91 & 26.02 \\ 22.3 & 22.4 & 22.7 & 22.6 & 22.7 & 22.6 & 24.4 & 24.7 & 25.43 & 26.17 \\ 19.3 & 19.3 & 19.6 & 19.6 & 19.6 & 19.6 & 19.7 & 20.0 & 20.26 & 20.52 \\ 22.8 & 22.8 & 23.1 & 23.0 & 23.0 & 22.9 & 22.8 & 23.0 & 23.12 & 23.23 \\ 25.3 & 25.3 & 25.6 & 25.5 & 25.5 & 25.5 & 25.6 & 25.9 & 26.21 & 26.47 \\ 23.1 & 23.1 & 23.4 & 23.4 & 23.4 & 23.2 & 23.1 & 23.2 & 23.34 & 23.43 \\ 0.0 & 0.0 & 0.0 & 0.0 & 0.0 & 0.0 & 0.0 & 0.0 & 0.0 & 0.0 \\ 0.0 & 0.0 & 0.0 & 0.0 & 0.0 & 0.0 & 0.0 & 0.0 & 0.0 & 0.0\end{array}$

$\begin{array}{rrrrrrrrrr}0.0 & 0.0 & 0.0 & 0.0 & 0.0 & 0.0 & 0.0 & 0.0 & 0.0 & 0.0 \\ 15.6 & 15.7 & 15.9 & 16.0 & 16.0 & 16.2 & 16.4 & 16.7 & 17.13 & 17.54 \\ 19.6 & 19.6 & 19.9 & 19.9 & 20.0 & 20.1 & 20.4 & 20.7 & 21.09 & 21.49 \\ 23.0 & 23.0 & 23.3 & 23.3 & 23.4 & 23.4 & 23.6 & 23.9 & 24.19 & 24.52 \\ 24.3 & 24.4 & 24.7 & 24.7 & 24.7 & 24.7 & 24.7 & 24.9 & 25.12 & 25.37 \\ 22.0 & 22.1 & 22.3 & 22.4 & 22.4 & 22.4 & 22.7 & 22.9 & 23.25 & 23.57 \\ 17.8 & 17.8 & 18.0 & 18.0 & 18.0 & 18.1 & 18.2 & 18.5 & 18.82 & 19.09 \\ 21.9 & 21.9 & 22.2 & 22.2 & 22.1 & 22.1 & 22.0 & 22.2 & 22.34 & 22.48 \\ 23.7 & 23.8 & 24.1 & 24.0 & 24.0 & 24.0 & 24.2 & 24.5 & 24.78 & 25.07 \\ 22.2 & 22.2 & 22.5 & 22.5 & 22.5 & 22.4 & 22.3 & 22.4 & 22.57 & 22.69 \\ 0.0 & 0.0 & 0.0 & 0.0 & 0.0 & 0.0 & 0.0 & 0.0 & 0.0 & 0.0 \\ 0.0 & 0.0 & 0.0 & 0.0 & 0.0 & 0.0 & 0.0 & 0.0 & 0.0 & 0.0 \\ & & & & & & & & & \\ & & & & & & & & & \\ 0.0 & 0.0 & 0.0 & 0.0 & 0.0 & 0.0 & 0.0 & 0.0 & 0.0 & 0.0 \\ 0.0 & 0.0 & 0.0 & 0.0 & 0.0 & 0.0 & 0.0 & 0.0 & 0.0 & 0.0 \\ 20.6 & 20.6 & 20.9 & 20.9 & 21.0 & 21.1 & 21.4 & 21.7 & 22.09 & 22.48\end{array}$

LPG Bi-Fuel

Minincompact Cars

Subcompact Cars

Compact Cars 
Table 58. New Light-Duty Vehicle Prices (Thousands 1990 Dollars)

Midsize Cars
Large Cars
2-Seater Cars
Small Pickup
Large Pickup
Small Van
Large Van
Small Utility
Large Utility
Electric
Minincompact Cars
Subcompact Cars
Compact Cars
Midsize Cars
Large Cars
2-Seater Cars
Small Pickup
Large Pickup
Small Van
Large Van
Small Utility
Large Utility
Diesel-Electric Hybrid
Minincompact Cars
Subcompact Cars
Compact Cars
Midsize Cars
Large Cars
2-Seater Cars
Small Pickup
Large Pickup
Small Van
Large Van
Small Utility
Large Utility

\begin{tabular}{|c|c|c|c|c|c|c|c|c|c|}
\hline 2002 & 2003 & 2004 & 2005 & 2006 & 2010 & 2015 & 2020 & 2025 & 2030 \\
\hline 24.0 & 24.0 & 24.3 & 24.3 & 24.4 & 24.4 & 24.6 & 24.9 & 25.19 & 25.52 \\
\hline 25.3 & 25.4 & 25.7 & 25.7 & 25.7 & 25.7 & 25.7 & 25.9 & 26.12 & 26.37 \\
\hline 23.0 & 23.1 & 23.3 & 23.4 & 23.4 & 23.4 & 23.7 & 23.9 & 24.25 & 24.57 \\
\hline 18.8 & 18.8 & 19.0 & 19.0 & 19.0 & 19.1 & 19.2 & 19.5 & 19.82 & 20.09 \\
\hline 22.9 & 22.9 & 23.2 & 23.2 & 23.1 & 23.1 & 23.0 & 23.2 & 23.34 & 23.48 \\
\hline 24.7 & 24.8 & 25.1 & 25.0 & 25.0 & 25.0 & 25.2 & 25.5 & 25.78 & 26.07 \\
\hline 23.2 & 23.2 & 23.5 & 23.5 & 23.5 & 23.4 & 23.3 & 23.4 & 23.57 & 23.69 \\
\hline 0.0 & 0.0 & 0.0 & 0.0 & 0.0 & 0.0 & 0.0 & 0.0 & 0.0 & 0.0 \\
\hline 0.0 & 0.0 & 0.0 & 0.0 & 0.0 & 0.0 & 0.0 & 0.0 & 0.0 & 0.0 \\
\hline 0.0 & 0.0 & 0.0 & 0.0 & 0.0 & 0.0 & 0.0 & 0.0 & 0.0 & 0.0 \\
\hline 27.8 & 28.2 & 28.9 & 29.2 & 29.5 & 29.1 & 28.2 & 28.5 & 28.58 & 28.68 \\
\hline 32.4 & 32.8 & 33.6 & 33.9 & 34.3 & 33.7 & 32.7 & 33.0 & 33.04 & 33.10 \\
\hline 0.0 & 0.0 & 0.0 & 0.0 & 0.0 & 0.0 & 0.0 & 0.0 & 0.0 & 0.0 \\
\hline 0.0 & 0.0 & 0.0 & 0.0 & 0.0 & 0.0 & 0.0 & 0.0 & 0.0 & 0.0 \\
\hline 33.4 & 23.8 & 24.6 & 25.0 & 25.4 & 24.8 & 23.8 & 24.0 & 22.25 & 20.60 \\
\hline 31.1 & 31.5 & 32.3 & 32.8 & 33.2 & 32.7 & 31.8 & 32.1 & 32.29 & 32.46 \\
\hline 0.0 & 0.0 & 0.0 & 0.0 & 0.0 & 0.0 & 0.0 & 0.0 & 0.0 & 0.0 \\
\hline 37.9 & 38.4 & 39.2 & 39.7 & 40.1 & 39.6 & 38.4 & 38.9 & 38.96 & 39.07 \\
\hline 0.0 & 0.0 & 0.0 & 0.0 & 0.0 & 0.0 & 0.0 & 0.0 & 0.0 & 0.0 \\
\hline 0.0 & 0.0 & 0.0 & 0.0 & 0.0 & 0.0 & 0.0 & 0.0 & 0.0 & 0.0 \\
\hline 0.0 & 0.0 & 0.0 & 0.0 & 0.0 & 0.0 & 0.0 & 0.0 & 0.0 & 0.0 \\
\hline 0.0 & 0.0 & 0.0 & 0.0 & 0.0 & 0.0 & 0.0 & 0.0 & 0.0 & 0.0 \\
\hline 39.9 & 25.3 & 25.4 & 25.3 & 25.3 & 25.1 & 25.1 & 25.4 & 23.00 & 20.81 \\
\hline 46.8 & 29.7 & 29.9 & 29.8 & 29.7 & 29.4 & 29.3 & 29.7 & 26.80 & 24.21 \\
\hline 52.4 & 32.9 & 33.0 & 32.9 & 32.7 & 32.3 & 32.1 & 32.4 & 29.07 & 26.09 \\
\hline 56.7 & 34.8 & 34.9 & 34.7 & 34.6 & 33.9 & 33.6 & 33.9 & 30.15 & 26.84 \\
\hline 49.1 & 30.6 & 30.7 & 30.6 & 30.4 & 29.9 & 29.6 & 29.9 & 26.76 & 23.95 \\
\hline 0.0 & 0.0 & 0.0 & 0.0 & 0.0 & 0.0 & 0.0 & 0.0 & 0.0 & 0.0 \\
\hline 0.0 & 0.0 & 0.0 & 0.0 & 0.0 & 0.0 & 0.0 & 0.0 & 0.0 & 0.0 \\
\hline 57.2 & 34.5 & 34.6 & 34.4 & 34.2 & 33.6 & 33.3 & 33.6 & 29.82 & 26.46 \\
\hline 0.0 & 0.0 & 0.0 & 0.0 & 0.0 & 0.0 & 0.0 & 0.0 & 0.0 & 0.0 \\
\hline 59.7 & 36.2 & 36.3 & 36.1 & 35.9 & 35.3 & 34.9 & 35.2 & 31.20 & 27.69 \\
\hline 67.9 & 39.2 & 39.3 & 39.0 & 38.8 & 37.9 & 37.3 & 37.6 & 32.87 & 28.75 \\
\hline
\end{tabular}

Fuel Cell Methanol

Minincompact Cars

Subcompact Cars

Compact Cars

Midsize Cars

Large Cars

2-Seater Cars

Small Pickup

Large Pickup

Small Van

Large Van

Small Utility

Large Utility

$\begin{array}{rrrrrrrrrr}0.0 & 0.0 & 0.0 & 0.0 & 0.0 & 0.0 & 0.0 & 0.0 & 0.0 & 0.0 \\ 0.0 & 0.0 & 0.0 & 0.0 & 0.0 & 0.0 & 0.0 & 0.0 & 0.0 & 0.0 \\ 0.0 & 0.0 & 0.0 & 74.8 & 68.2 & 49.6 & 37.7 & 32.3 & 24.43 & 18.48 \\ 0.0 & 0.0 & 0.0 & 84.2 & 76.7 & 55.4 & 41.8 & 35.5 & 26.66 & 20.01 \\ 0.0 & 0.0 & 0.0 & 92.0 & 83.5 & 59.8 & 44.7 & 37.6 & 27.95 & 20.77 \\ 0.0 & 0.0 & 0.0 & 78.9 & 71.9 & 52.0 & 39.2 & 33.2 & 24.94 & 18.72 \\ 0.0 & 0.0 & 0.0 & 79.7 & 72.4 & 51.3 & 37.7 & 31.2 & 22.81 & 16.70 \\ 0.0 & 0.0 & 0.0 & 0.0 & 0.0 & 0.0 & 0.0 & 0.0 & 0.0 & 0.0 \\ 0.0 & 0.0 & 0.0 & 93.6 & 85.0 & 60.9 & 45.2 & 37.7 & 27.90 & 20.63 \\ 0.0 & 0.0 & 0.0 & 0.0 & 0.0 & 0.0 & 0.0 & 0.0 & 0.0 & 0.0 \\ 0.0 & 0.0 & 0.0 & 0.0 & 0.0 & 0.0 & 0.0 & 0.0 & 0.0 & 0.0 \\ 0.0 & 0.0 & 0.0 & 0.0 & 0.0 & 0.0 & 0.0 & 0.0 & 0.0 & 0.0 \\ & & & & & & & & & \\ 0.0 & 0.0 & 0.0 & 0.0 & 0.0 & 0.0 & 0.0 & 0.0 & 0.0 & 0.0 \\ 0.0 & 0.0 & 0.0 & 0.0 & 0.0 & 0.0 & 0.0 & 0.0 & 0.0 & 0.0 \\ 0.0 & 0.0 & 0.0 & 65.4 & 60.8 & 47.9 & 39.7 & 36.0 & 29.53 & 24.23 \\ 0.0 & 0.0 & 0.0 & 72.8 & 67.5 & 52.7 & 43.3 & 39.0 & 31.74 & 25.81 \\ 0.0 & 0.0 & 0.0 & 78.6 & 72.7 & 56.2 & 45.7 & 40.9 & 32.94 & 26.53 \\ 0.0 & 0.0 & 0.0 & 68.5 & 63.6 & 49.7 & 40.9 & 36.8 & 29.99 & 24.41 \\ 0.0 & 0.0 & 0.0 & 0.0 & 0.0 & 0.0 & 0.0 & 0.0 & 0.0 & 0.0 \\ 0.0 & 0.0 & 0.0 & 0.0 & 0.0 & 0.0 & 0.0 & 0.0 & 0.0 & 0.0 \\ 0.0 & 0.0 & 0.0 & 79.5 & 73.6 & 56.8 & 46.0 & 40.8 & 32.74 & 26.24 \\ 0.0 & 0.0 & 0.0 & 0.0 & 0.0 & 0.0 & 0.0 & 0.0 & 0.0 & 0.0 \\ 0.0 & 0.0 & 0.0 & 0.0 & 0.0 & 0.0 & 0.0 & 0.0 & 0.0 & 0.0 \\ 0.0 & 0.0 & 0.0 & 0.0 & 0.0 & 0.0 & 0.0 & 0.0 & 0.0 & 0.0\end{array}$

Fuel Cell Hydrogen

Minincompact Cars

Subcompact Cars

Compact Cars

Midsize Cars

Large Cars

2-Seater Cars

Small Pickup

Large Pickup

Small Van

Large Van

Small Utility

Large Utility 
Table 58. New Light-Duty Vehicle Prices

(Thousands 1990 Dollars)

\begin{tabular}{|c|c|c|c|c|c|c|c|c|c|c|}
\hline & 2002 & 2003 & 2004 & 2005 & 2006 & 2010 & 2015 & 2020 & 2025 & 2030 \\
\hline \multicolumn{11}{|l|}{ Fuel Cell Gasoline } \\
\hline Minincompact Cars & 0.0 & 0.0 & 0.0 & 0.0 & 0.0 & 0.0 & 0.0 & 0.0 & 0.0 & 0.0 \\
\hline Subcompact Cars & 0.0 & 0.0 & 0.0 & 0.0 & 0.0 & 0.0 & 0.0 & 0.0 & 0.0 & 0.0 \\
\hline Compact Cars & 0.0 & 0.0 & 0.0 & 82.1 & 74.5 & 53.1 & 39.4 & 33.0 & 24.43 & 18.06 \\
\hline Midsize Cars & 0.0 & 0.0 & 0.0 & 92.6 & 83.9 & 59.3 & 43.6 & 36.4 & 26.68 & 19.56 \\
\hline Large Cars & 0.0 & 0.0 & 0.0 & 101.3 & 91.5 & 64.2 & 46.7 & 38.6 & 28.00 & 20.32 \\
\hline 2-Seater Cars & 0.0 & 0.0 & 0.0 & 86.8 & 78.7 & 55.7 & 40.9 & 34.1 & 24.97 & 18.31 \\
\hline Large Pickup & 0.0 & 0.0 & 0.0 & 0.0 & 0.0 & 0.0 & 0.0 & 0.0 & 0.0 & 0.0 \\
\hline Small Van & 0.0 & 0.0 & 0.0 & 103.2 & 93.4 & 65.5 & 47.4 & 38.8 & 28.02 & 20.24 \\
\hline Large Van & 0.0 & 0.0 & 0.0 & 0.0 & 0.0 & 0.0 & 0.0 & 0.0 & 0.0 & 0.0 \\
\hline Small Utility & 0.0 & 0.0 & 0.0 & 0.0 & 0.0 & 0.0 & 0.0 & 0.0 & 0.0 & 0.0 \\
\hline Large Utility & 0.0 & 0.0 & 0.0 & 0.0 & 0.0 & 0.0 & 0.0 & 0.0 & 0.0 & 0.0 \\
\hline
\end{tabular}

$\mathrm{N} / \mathrm{A}=$ Not applicable

Note: The historical data used for the projections were the most available as of July 31, 1999. The numbers presented for 1998 are estimates and may differ from official EIA data reports. Also. please see EIA data publications and the Short-Term Energy Outlook for the latest estimates for 1999.

Sources: 1998 derived using: Energy and Environmental Analysis Inc., Updates to

the Fuels Economy Model, prepared for Energy Information Administration (EIA)

(Washington, DC, June 1998); and and EIA, AEO2000 National Energy Modeling System run

AEO2K.D100199A. Projection: EIA, AEO2000 National Energy Modeling System run AEO2K.D100199A. 
Table 59. New Light-Duty Vehicle Range (Miles)

\begin{tabular}{|c|c|c|c|c|c|c|c|c|c|c|}
\hline & 2002 & 2003 & 2004 & 2005 & 2006 & 2010 & 2015 & 2020 & 2025 & 2030 \\
\hline \multicolumn{11}{|l|}{ Gasoline } \\
\hline Minincompact Cars & 486 & 500 & 500 & 505 & 511 & 529 & 535 & 537 & 554.41 & 571.98 \\
\hline Subcompact Cars & 476 & 485 & 485 & 486 & 488 & 498 & 497 & 492 & 499.23 & 506.14 \\
\hline Compact Cars & 474 & 487 & 487 & 488 & 491 & 503 & 505 & 501 & 511.18 & 521.37 \\
\hline Midsize Cars & 472 & 482 & 482 & 484 & 487 & 503 & 507 & 507 & 518.49 & 530.48 \\
\hline Large Cars & 515 & 529 & 529 & 532 & 537 & 559 & 572 & 575 & 593.62 & 612.55 \\
\hline Small Pickup & 418 & 421 & 419 & 418 & 418 & 419 & 427 & 432 & 437.29 & 442.29 \\
\hline Large Pickup & 401 & 404 & 402 & 403 & 407 & 415 & 432 & 444 & 455.55 & 467.00 \\
\hline Small Van & 481 & 486 & 486 & 487 & 489 & 491 & 501 & 512 & 523.22 & 534.18 \\
\hline Large Van & 454 & 462 & 462 & 466 & 472 & 488 & 509 & 527 & 550.43 & 574.77 \\
\hline Small Utility & 428 & 434 & 433 & 433 & 436 & 443 & 455 & 464 & 475.40 & 487.47 \\
\hline Large Utility & 416 & 422 & 422 & 425 & 431 & 447 & 464 & 478 & 496.67 & 516.57 \\
\hline \multicolumn{11}{|c|}{ Turbo Direct Injection Diesel } \\
\hline Compact Cars & 615 & 632 & 631 & 632 & 635 & 648 & 648 & 641 & 651.58 & 661.93 \\
\hline Midsize Cars & 641 & 655 & 654 & 657 & 662 & 680 & 683 & 682 & 695.79 & 710.36 \\
\hline Large Cars & 709 & 729 & 729 & 732 & 739 & 769 & 785 & 790 & 814.38 & 839.51 \\
\hline 2-Seater Cars & 0 & 0 & 0 & 0 & 0 & 0 & 0 & 0 & 0 & 0 \\
\hline Small Pickup & 567 & 573 & 571 & 569 & 570 & 574 & 585 & 589 & 597.47 & 605.68 \\
\hline Large Pickup & 546 & 549 & 546 & 549 & 553 & 565 & 587 & 605 & 619.81 & 635.38 \\
\hline Small Van & 605 & 613 & 611 & 611 & 614 & 623 & 639 & 645 & 658.84 & 672.49 \\
\hline Large Van & 613 & 624 & 623 & 629 & 638 & 659 & 687 & 712 & 743.07 & 775.94 \\
\hline Small Utility & 565 & 572 & 571 & 571 & 575 & 586 & 603 & 611 & 626.82 & 642.71 \\
\hline Large Utility & 660 & 669 & 670 & 675 & 685 & 709 & 737 & 758 & 788.61 & 820.21 \\
\hline \multicolumn{11}{|l|}{ Methanol } \\
\hline Minincompact Cars & 0 & 0 & 0 & 0 & 0 & 0 & 0 & 0 & 0 & 0 \\
\hline Subcompact Cars & 299 & 305 & 305 & 305 & 306 & 311 & 310 & 307 & 310.60 & 314.12 \\
\hline Compact Cars & 287 & 295 & 294 & 295 & 296 & 303 & 302 & 299 & 304.07 & 308.90 \\
\hline Midsize Cars & 299 & 306 & 305 & 306 & 309 & 317 & 319 & 318 & 324.70 & 331.50 \\
\hline Large Pickup & 255 & 256 & 255 & 256 & 258 & 264 & 274 & 282 & 289.24 & 296.51 \\
\hline Small Van & 282 & 286 & 285 & 285 & 286 & 291 & 298 & 301 & 307.46 & 313.83 \\
\hline Large Van & 286 & 291 & 291 & 293 & 298 & 307 & 321 & 332 & 346.77 & 362.10 \\
\hline Small Utility & 0 & 0 & 0 & 0 & 0 & 0 & 0 & 0 & 0 & 0 \\
\hline Large Utility & 0 & 0 & 0 & 0 & 0 & 0 & 0 & 0 & 0 & 0 \\
\hline \multicolumn{11}{|l|}{ Methanol Flex } \\
\hline Minincompact Cars & 0 & 0 & 0 & 0 & 0 & 0 & 0 & 0 & 0 & 0 \\
\hline Subcompact Cars & 271 & 276 & 276 & 276 & 277 & 282 & 281 & 278 & 281.02 & 284.21 \\
\hline Compact Cars & 260 & 267 & 266 & 267 & 268 & 274 & 273 & 271 & 275.11 & 279.48 \\
\hline Midsize Cars & 271 & 276 & 276 & 277 & 279 & 287 & 288 & 288 & 293.78 & 299.93 \\
\hline Large Cars & 299 & 308 & 308 & 309 & 312 & 325 & 332 & 334 & 343.85 & 354.46 \\
\hline 2-Seater Cars & 263 & 272 & 273 & 276 & 279 & 292 & 298 & 301 & 313.03 & 325.56 \\
\hline Small Pickup & 240 & 242 & 241 & 240 & 241 & 243 & 247 & 249 & 252.27 & 255.73 \\
\hline Large Pickup & 230 & 232 & 231 & 232 & 234 & 239 & 248 & 255 & 261.70 & 268.27 \\
\hline Small Van & 255 & 259 & 258 & 258 & 259 & 263 & 270 & 273 & 278.18 & 283.94 \\
\hline Large Van & 259 & 263 & 263 & 265 & 269 & 278 & 290 & 300 & 313.74 & 327.62 \\
\hline Small Utility & 238 & 242 & 241 & 241 & 243 & 247 & 255 & 258 & 264.66 & 271.37 \\
\hline Large Utility & 279 & 283 & 283 & 285 & 289 & 300 & 311 & 320 & 332.97 & 346.31 \\
\hline \multicolumn{11}{|l|}{ Ethanol } \\
\hline Minincompact Cars & 0 & 0 & 0 & 0 & 0 & 0 & 0 & 0 & 0 & 0 \\
\hline Subcompact Cars & 361 & 368 & 368 & 368 & 369 & 375 & 374 & 370 & 374.69 & 378.94 \\
\hline Compact Cars & 346 & 356 & 355 & 356 & 358 & 365 & 365 & 361 & 366.81 & 372.64 \\
\hline Midsize Cars & 361 & 369 & 368 & 370 & 372 & 383 & 385 & 384 & 391.71 & 399.91 \\
\hline Large Cars & 399 & 410 & 410 & 412 & 416 & 433 & 442 & 445 & 458.47 & 472.61 \\
\hline 2-Seater Cars & 351 & 362 & 363 & 368 & 373 & 389 & 397 & 401 & 417.37 & 434.08 \\
\hline Small Pickup & 319 & 322 & 321 & 320 & 321 & 323 & 330 & 332 & 336.36 & 340.98 \\
\hline Large Pickup & 307 & 309 & 308 & 309 & 312 & 318 & 331 & 340 & 348.93 & 357.69 \\
\hline
\end{tabular}


Table 59. New Light-Duty Vehicle Range (Miles)

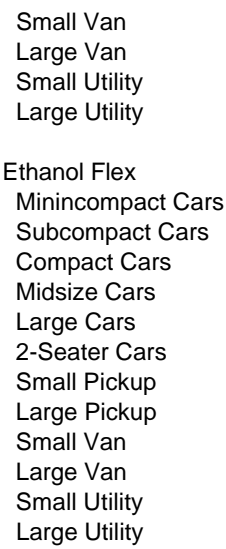

$\begin{array}{rrrrrrrrrr}0 & 0 & 0 & 0 & 0 & 0 & 0 & 0 & 0 & 0 \\ 347 & 353 & 353 & 353 & 354 & 361 & 360 & 356 & 359.90 & 363.98 \\ 333 & 342 & 341 & 342 & 343 & 351 & 350 & 347 & 352.33 & 357.93 \\ 346 & 354 & 354 & 355 & 358 & 368 & 369 & 369 & 376.24 & 384.12 \\ 383 & 394 & 394 & 396 & 399 & 416 & 425 & 427 & 440.37 & 453.96 \\ 337 & 348 & 349 & 353 & 358 & 374 & 382 & 385 & 400.90 & 416.94 \\ 307 & 310 & 309 & 308 & 308 & 311 & 316 & 319 & 323.08 & 327.52 \\ 295 & 297 & 296 & 297 & 299 & 306 & 318 & 327 & 335.16 & 343.58 \\ 327 & 331 & 331 & 330 & 332 & 337 & 346 & 349 & 356.26 & 363.64 \\ 332 & 337 & 337 & 340 & 345 & 356 & 372 & 385 & 401.81 & 419.58 \\ 305 & 310 & 309 & 309 & 311 & 317 & 326 & 331 & 338.95 & 347.54 \\ 357 & 362 & 362 & 365 & 370 & 384 & 399 & 410 & 426.43 & 443.52\end{array}$

$\begin{array}{rrrrrrrrrr}0 & 0 & 0 & 0 & 0 & 0 & 0 & 0 & 0 & 0 \\ 0 & 0 & 0 & 0 & 0 & 0 & 0 & 0 & 0 & 0 \\ 273 & 281 & 280 & 281 & 282 & 288 & 288 & 285 & 289.59 & 294.19 \\ 285 & 291 & 291 & 292 & 294 & 302 & 304 & 303 & 309.24 & 315.72 \\ 315 & 324 & 324 & 325 & 328 & 342 & 349 & 351 & 361.95 & 373.11 \\ 277 & 286 & 287 & 290 & 294 & 307 & 314 & 317 & 329.51 & 342.69 \\ 252 & 254 & 254 & 253 & 253 & 255 & 260 & 262 & 265.54 & 269.19 \\ 243 & 244 & 243 & 244 & 246 & 251 & 261 & 269 & 275.47 & 282.39 \\ 269 & 272 & 272 & 271 & 273 & 277 & 284 & 287 & 292.82 & 298.88 \\ 273 & 277 & 277 & 279 & 283 & 293 & 306 & 316 & 330.26 & 344.86 \\ 0 & 0 & 0 & 0 & 0 & 0 & 0 & 0 & 0 & 0 \\ 0 & 0 & 0 & 0 & 0 & 0 & 0 & 0 & 0 & 0\end{array}$

$\begin{array}{rrrrrrrrrr}0 & 0 & 0 & 0 & 0 & 0 & 0 & 0 & 0 & 0 \\ 0 & 0 & 0 & 0 & 0 & 0 & 0 & 0 & 0 & 0 \\ 228 & 234 & 234 & 234 & 235 & 240 & 240 & 238 & 241.32 & 245.16 \\ 237 & 243 & 242 & 243 & 245 & 252 & 253 & 252 & 257.70 & 263.10 \\ 263 & 270 & 270 & 271 & 274 & 285 & 291 & 293 & 301.62 & 310.93 \\ 231 & 238 & 239 & 242 & 245 & 256 & 261 & 264 & 274.59 & 285.58 \\ 210 & 212 & 211 & 211 & 211 & 213 & 217 & 218 & 221.29 & 224.33 \\ 202 & 203 & 202 & 203 & 205 & 209 & 217 & 224 & 229.56 & 235.33 \\ 224 & 227 & 226 & 226 & 227 & 231 & 237 & 239 & 244.02 & 249.07 \\ 227 & 231 & 231 & 233 & 236 & 244 & 255 & 264 & 275.21 & 287.38 \\ 0 & 0 & 0 & 0 & 0 & 0 & 0 & 0 & 0 & 0 \\ 0 & 0 & 0 & 0 & 0 & 0 & 0 & 0 & 0 & 0\end{array}$

$\begin{array}{rrrrrrrrrr}0 & 0 & 0 & 0 & 0 & 0 & 0 & 0 & 0 & 0 \\ 404 & 411 & 411 & 411 & 413 & 420 & 419 & 414 & 419.07 & 423.82 \\ 387 & 398 & 397 & 398 & 400 & 408 & 408 & 404 & 410.25 & 416.77 \\ 403 & 412 & 412 & 413 & 417 & 428 & 430 & 429 & 438.09 & 447.26 \\ 446 & 459 & 459 & 461 & 465 & 484 & 494 & 497 & 512.76 & 528.58 \\ 393 & 405 & 406 & 411 & 417 & 435 & 445 & 449 & 466.80 & 485.48 \\ 357 & 361 & 359 & 358 & 359 & 362 & 369 & 371 & 376.19 & 381.36 \\ 344 & 346 & 344 & 345 & 348 & 356 & 370 & 381 & 390.25 & 400.05 \\ 381 & 386 & 385 & 385 & 386 & 392 & 402 & 406 & 414.83 & 423.42 \\ 386 & 393 & 392 & 396 & 401 & 415 & 433 & 448 & 467.86 & 488.55 \\ 0 & 0 & 0 & 0 & 0 & 0 & 0 & 0 & 0 & 0 \\ 0 & 0 & 0 & 0 & 0 & 0 & 0 & 0 & 0 & 0\end{array}$

$\begin{array}{rrrrrrrrrr}0 & 0 & 0 & 0 & 0 & 0 & 0 & 0 & 0 & 0 \\ 0 & 0 & 0 & 0 & 0 & 0 & 0 & 0 & 0 & 0 \\ 364 & 374 & 374 & 374 & 376 & 384 & 384 & 380 & 386.12 & 392.25\end{array}$


Table 59. New Light-Duty Vehicle Range (Miles)

Midsize Cars
Large Cars
2-Seater Cars
Small Pickup
Large Pickup
Small Van
Large Van
Small Utility
Large Utility
Electric
Minincompact Cars
Subcompact Cars
Compact Cars
Midsize Cars
Large Cars
2-Seater Cars
Small Pickup
Large Pickup
Small Van
Large Van
Small Utility
Large Utility
Diesel-Electric Hybrid
Minincompact Cars
Subcompact Cars
Compact Cars
Midsize Cars
Large Cars
2-Seater Cars
Small Pickup
Large Pickup
Small Van
Large Van
Small Utility
Large Utility

$\begin{array}{rrrrrrrrrr}2002 & \mathbf{2 0 0 3} & \mathbf{2 0 0 4} & \mathbf{2 0 0 5} & \mathbf{2 0 0 6} & \mathbf{2 0 1 0} & \mathbf{2 0 1 5} & \mathbf{2 0 2 0} & \mathbf{2 0 2 5} & \mathbf{2 0 3 0} \\ 380 & 388 & 388 & 389 & 392 & 403 & 405 & 404 & 412.32 & 420.95 \\ 420 & 432 & 432 & 434 & 438 & 455 & 465 & 468 & 482.60 & 497.49 \\ 370 & 381 & 382 & 387 & 392 & 409 & 418 & 422 & 439.34 & 456.93 \\ 336 & 339 & 338 & 337 & 338 & 340 & 347 & 349 & 354.06 & 358.92 \\ 323 & 325 & 324 & 325 & 328 & 335 & 348 & 358 & 367.29 & 376.52 \\ 358 & 363 & 362 & 362 & 364 & 369 & 379 & 383 & 390.43 & 398.51 \\ 364 & 370 & 369 & 372 & 378 & 390 & 407 & 422 & 440.34 & 459.81 \\ 0 & 0 & 0 & 0 & 0 & 0 & 0 & 0 & 0 & 0 \\ 0 & 0 & 0 & 0 & 0 & 0 & 0 & 0 & 0 & 0\end{array}$

Fuel Cell Methanol Minincompact Cars

Subcompact Cars

Compact Cars

Midsize Cars

Large Cars

2-Seater Cars

Small Pickup

Large Pickup

Small Van

Large Van

Small Utility

Large Utility

$\begin{array}{rr}0 & \\ 80 & 80 \\ 80 & 80 \\ 0 & \\ 0 & 0 \\ 80 & 80 \\ 80 & 80 \\ 0 & \\ 80 & 80 \\ 0 & \\ 0 & \\ 0 & \end{array}$

$\begin{array}{rrrrrrrr}0 & 0 & 0 & 0 & 0 & 0 & 0 & 0 \\ 80 & 80 & 80 & 80 & 80 & 80 & 80 & 80 \\ 80 & 80 & 80 & 80 & 80 & 80 & 80 & 80 \\ 0 & 0 & 0 & 0 & 0 & 0 & 0 & 0 \\ 0 & 0 & 0 & 0 & 0 & 0 & 0 & 0 \\ 80 & 80 & 80 & 80 & 80 & 80 & 80 & 80 \\ 80 & 80 & 80 & 80 & 80 & 80 & 80 & 80 \\ 0 & 0 & 0 & 0 & 0 & 0 & 0 & 0 \\ 80 & 80 & 80 & 80 & 80 & 80 & 80 & 80 \\ 0 & 0 & 0 & 0 & 0 & 0 & 0 & 0 \\ 0 & 0 & 0 & 0 & 0 & 0 & 0 & 0 \\ 0 & 0 & 0 & 0 & 0 & 0 & 0 & 0\end{array}$

$\begin{array}{rrr}0 & 0 & 0 \\ 618 & 629 & 629 \\ 592 & 608 & 608 \\ 617 & 631 & 630 \\ 683 & 702 & 702 \\ 601 & 620 & 622 \\ 0 & 0 & 0 \\ 0 & 0 & 0 \\ 582 & 590 & 589 \\ 0 & 0 & 0 \\ 544 & 551 & 550 \\ 636 & 645 & 645\end{array}$

0
629
608
632
705
629
0
0
588
0
550
650

0
631
612
637
711
637
0
0
591
0
553
659

0
642
624
654
740
665
0
0
600
0
564
683

0
640
624
658
756
680
0
0
615
0
581
710

0
634
618
656
761
686
0
0
622
0
589
730

$\begin{array}{rr}0 & 0 \\ 640.92 & 648.19 \\ 627.44 & 637.41 \\ 670.02 & 684.05 \\ 784.22 & 808.41 \\ 713.93 & 742.50 \\ 0 & 0 \\ 0 & 0 \\ 634.44 & 647.58 \\ 0 & 0 \\ 603.60 & 618.91 \\ 759.40 & 789.83\end{array}$

Fuel Cell Hydrogen

Minincompact Cars

Subcompact Cars

Compact Cars

Midsize Cars

Large Cars

2-Seater Cars

Small Pickup

Large Pickup

Small Van

Large Van

Small Utility

Large Utility

$\begin{array}{rrrr}0 & 0 & 0 & \\ 0 & 0 & 0 & \\ 467 & 468 & 470 & 480 \\ 485 & 486 & 490 & 503 \\ 540 & 542 & 547 & 569 \\ 478 & 484 & 490 & 5 \\ 423 & 421 & 422 & 425 \\ 0 & 0 & 0 & \\ 453 & 452 & 455 & 461 \\ 0 & 0 & 0 & \\ 0 & 0 & 0 & \\ 0 & 0 & 0 & \end{array}$

0
0
480
503
569
512
425
0
461
0
0
0

0
0
480
506
582
523
434
0
473
0
0
0

0
0
475
505
585
528
437
0
478
0
0
0

$\begin{array}{rr}0 & 0 \\ 0 & 0 \\ 482.65 & 490.32 \\ 515.40 & 526.19 \\ 603.25 & 621.86 \\ 549.18 & 571.16 \\ 442.57 & 448.65 \\ 0 & 0 \\ 488.03 & 498.14 \\ 0 & 0 \\ 0 & 0 \\ 0 & 0\end{array}$

$\begin{array}{rrr}0 & 0 & 0 \\ 0 & 0 & 0 \\ 456 & 468 & 467 \\ 475 & 485 & 485 \\ 525 & 540 & 540 \\ 462 & 477 & 478 \\ 0 & 0 & 0 \\ 0 & 0 & 0 \\ 448 & 454 & 453 \\ 0 & 0 & 0 \\ 0 & 0 & 0 \\ 0 & 0 & 0\end{array}$

0
0
480
506
582
523
0
0
473
0
0
0

$\begin{array}{rrr}0 & 0 & 0 \\ 0 & 0 & 0 \\ 475 & 482.65 & 490.32 \\ 505 & 515.40 & 526.19 \\ 585 & 603.25 & 621.86 \\ 528 & 549.18 & 571.16 \\ 0 & 0 & 0 \\ 0 & 0 & 0 \\ 478 & 488.03 & 498.14 \\ 0 & 0 & 0 \\ 0 & 0 & 0 \\ 0 & 0 & 0\end{array}$


Table 59. New Light-Duty Vehicle Range

(Miles)

\begin{tabular}{|c|c|c|c|c|c|c|c|c|c|c|}
\hline & 2002 & 2003 & 2004 & 2005 & 2006 & 2010 & 2015 & 2020 & 2025 & 2030 \\
\hline \multicolumn{11}{|l|}{ Fuel Cell Gasoline } \\
\hline Minincompact Cars & 0 & 0 & 0 & 0 & 0 & 0 & 0 & 0 & 0 & 0 \\
\hline Subcompact Cars & 0 & 0 & 0 & 0 & 0 & 0 & 0 & 0 & 0 & 0 \\
\hline Compact Cars & 456 & 468 & 467 & 468 & 470 & 480 & 480 & 475 & 482.65 & 490.32 \\
\hline Midsize Cars & 475 & 485 & 485 & 486 & 490 & 503 & 506 & 505 & 515.40 & 526.19 \\
\hline Large Cars & 525 & 540 & 540 & 542 & 547 & 569 & 582 & 585 & 603.25 & 621.86 \\
\hline 2-Seater Cars & 462 & 477 & 478 & 484 & 490 & 512 & 523 & 528 & 549.18 & 571.16 \\
\hline Large Pickup & 0 & 0 & 0 & 0 & 0 & 0 & 0 & 0 & 0 & 0 \\
\hline Small Van & 448 & 454 & 453 & 452 & 455 & 461 & 473 & 478 & 488.03 & 498.14 \\
\hline Large Van & 0 & 0 & 0 & 0 & 0 & 0 & 0 & 0 & 0 & 0 \\
\hline Small Utility & 0 & 0 & 0 & 0 & 0 & 0 & 0 & 0 & 0 & 0 \\
\hline Large Utility & 0 & 0 & 0 & 0 & 0 & 0 & 0 & 0 & 0 & 0 \\
\hline
\end{tabular}

$\mathrm{N} / \mathrm{A}=$ Not applicable

Note: The historical data used for the projections were the most available as of July 31, 1999. The numbers presented for 1998 are estimates and may differ from official EIA data reports. Also. please see EIA data publications and the Short-Term Energy Outlook for the latest estimates for 1999.

Sources: 1998 derived using: Energy and Environmental Analysis Inc., Updates to

the Fuels Economy Model, prepared for Energy Information Administration (EIA)

(Washington, DC, June 1998); and and EIA, AEO2000 National Energy Modeling System run

AEO2K.D100199A. Projection: EIA, AEO2000 National Energy Modeling System run AEO2K.D100199A. 
Table 73. Electric Power Projections for EMM Region Unites States Total

\begin{tabular}{|c|c|c|c|c|c|c|c|c|c|c|}
\hline & 2002 & 2003 & 2004 & 2005 & 2006 & 2010 & 2015 & 2020 & 2025 & 2030 \\
\hline \multicolumn{11}{|l|}{$\begin{array}{l}\text { Electricity Generating Capacity } 1 / \\
\text { (gigawatts) }\end{array}$} \\
\hline Coal Steam & 306.36 & 303.52 & 301.66 & 301.62 & 301.76 & 301.66 & 306.80 & 316.95 & 319.69 & 322.45 \\
\hline Other Fossil Steam 2/ & 136.87 & 130.15 & 126.93 & 125.29 & 123.01 & 119.52 & 117.07 & 109.87 & 104.29 & 99.00 \\
\hline Combined Cycle & 31.60 & 35.47 & 46.42 & 55.75 & 64.14 & 93.05 & 124.71 & 154.64 & 247.70 & 396.76 \\
\hline Combustion Turbine/Diesel & 89.01 & 100.17 & 104.16 & 115.01 & 122.29 & 153.48 & 180.44 & 202.29 & 254.90 & 321.19 \\
\hline Nuclear Power & 97.46 & 94.99 & 93.40 & 93.40 & 89.01 & 84.14 & 67.35 & 56.97 & 50.46 & 44.70 \\
\hline Pumped Storage/Other 3/ & 19.93 & 19.98 & 20.02 & 20.02 & 20.02 & 20.02 & 20.02 & 20.02 & 20.05 & 20.09 \\
\hline Fuel Cells & 0.00 & 0.01 & 0.01 & 0.02 & 0.02 & 0.04 & 0.05 & 0.07 & 0.23 & 0.76 \\
\hline Renewable 4/ & 89.96 & 90.27 & 90.70 & 91.13 & 91.74 & 93.84 & 95.33 & 96.67 & 98.96 & 101.31 \\
\hline Total Capability & 771.19 & 774.54 & 783.29 & 802.24 & 811.99 & 865.75 & 911.76 & 957.47 & 1015.17 & 1076.34 \\
\hline \multicolumn{11}{|l|}{ Cumulative Planned Additions 5/ } \\
\hline Coal Steam & 0.08 & 0.08 & 0.08 & 0.08 & 0.08 & 0.08 & 0.08 & 0.08 & & \\
\hline Other Fossil Steam 2/ & 0.00 & 0.00 & 0.00 & 0.00 & 0.00 & 0.00 & 0.00 & 0.00 & & \\
\hline Combined Cycle & 4.69 & 4.69 & 4.69 & 4.69 & 4.69 & 4.69 & 4.69 & 4.69 & & \\
\hline Combustion Turbine/Diesel & 1.47 & 1.47 & 1.47 & 1.47 & 1.47 & 1.47 & 1.47 & 1.47 & & \\
\hline Nuclear Power & 0.00 & 0.00 & 0.00 & 0.00 & 0.00 & 0.00 & 0.00 & 0.00 & & \\
\hline Pumped Storage/Other 3/ & 0.00 & 0.00 & 0.00 & 0.00 & 0.00 & 0.00 & 0.00 & 0.00 & & \\
\hline Fuel Cells & 0.00 & 0.01 & 0.01 & 0.02 & 0.02 & 0.04 & 0.05 & 0.07 & & \\
\hline Renewable 4/ & 1.80 & 2.02 & 2.41 & 2.67 & 3.16 & 4.78 & 5.73 & 5.92 & & \\
\hline Total (planned) & 8.04 & 8.27 & 8.66 & 8.93 & 9.43 & 11.06 & 12.02 & 12.23 & & \\
\hline \multicolumn{11}{|l|}{ Cumulative Unplanned Additions 5/ } \\
\hline Coal Steam & 0.02 & 0.02 & 0.13 & 0.72 & 1.12 & 3.78 & 9.53 & 20.97 & & \\
\hline Other Fossil Steam 2/ & 0.00 & 0.00 & 0.00 & 0.00 & 0.00 & 0.00 & 0.00 & 0.00 & & \\
\hline Combined Cycle & 7.44 & 11.30 & 22.30 & 31.63 & 40.02 & 68.93 & 100.59 & 130.52 & & \\
\hline Combustion Turbine/Diesel & 14.40 & 26.16 & 30.42 & 42.19 & 49.80 & 81.90 & 109.35 & 132.33 & & \\
\hline Nuclear Power & 0.00 & 0.00 & 0.00 & 0.00 & 0.00 & 0.00 & 0.00 & 0.00 & & \\
\hline Pumped Storage/Other 3/ & 0.00 & 0.00 & 0.00 & 0.00 & 0.00 & 0.00 & 0.00 & 0.00 & & \\
\hline Fuel Cells & 0.00 & 0.00 & 0.00 & 0.00 & 0.00 & 0.00 & 0.00 & 0.00 & & \\
\hline Renewable 4/ & 0.82 & 0.90 & 0.97 & 1.07 & 1.15 & 1.77 & 2.60 & 3.75 & & \\
\hline Total (unplanned) & 22.68 & 38.38 & 53.83 & 75.61 & 92.10 & 156.39 & 222.07 & 287.57 & & \\
\hline Cumulative Total Additions & 30.72 & 46.65 & 62.49 & 84.54 & 101.52 & 167.45 & 234.09 & 299.80 & & \\
\hline Cumulative Retirements & 4.62 & 17.84 & 25.63 & 28.88 & 36.25 & 48.41 & 69.03 & 89.03 & & \\
\hline \multicolumn{11}{|l|}{ Cogenerators $6 /$} \\
\hline \multicolumn{11}{|l|}{ Capacity } \\
\hline Coal & 8.98 & 8.98 & 8.98 & 8.98 & 8.98 & 8.98 & 8.97 & 8.97 & 9.01 & 9.05 \\
\hline Petroleum & 1.32 & 1.32 & 1.32 & 1.32 & 1.32 & 1.32 & 1.32 & 1.32 & 1.33 & 1.33 \\
\hline Natural Gas & 35.39 & 35.51 & 35.62 & 35.75 & 35.86 & 36.42 & 37.34 & 38.42 & 40.11 & 41.88 \\
\hline Other Gaseous Fuels & 0.74 & 0.74 & 0.75 & 0.76 & 0.76 & 0.81 & 0.88 & 0.96 & 1.15 & 1.38 \\
\hline Renewables & 8.04 & 8.21 & 8.38 & 8.55 & 8.69 & 9.21 & 9.78 & 10.31 & 11.04 & 11.81 \\
\hline Other & 0.12 & 0.12 & 0.12 & 0.12 & 0.12 & 0.13 & 0.14 & 0.15 & 0.18 & 0.21 \\
\hline Total & 54.59 & 54.88 & 55.16 & 55.47 & 55.73 & 56.86 & 58.44 & 60.14 & 62.71 & 65.38 \\
\hline \multicolumn{11}{|l|}{$\begin{array}{l}\text { Electricity Demand } \\
\text { (billion kilowatthours) }\end{array}$} \\
\hline Residential & 1221.15 & 1239.63 & 1258.95 & 1280.18 & 1298.32 & 1377.86 & 1463.30 & 1547.60 & 1665.67 & 1792.74 \\
\hline Commercial/Other & 1135.66 & 1151.27 & 1167.92 & 1188.04 & 1204.40 & 1276.01 & 1342.59 & 1369.32 & 1457.97 & 1552.35 \\
\hline Industrial & 1079.91 & 1105.43 & 1125.78 & 1147.85 & 1163.39 & 1216.05 & 1301.16 & 1376.39 & 1466.53 & 1562.58 \\
\hline Transportation & 20.33 & 22.52 & 24.64 & 26.58 & 28.33 & 34.64 & 41.34 & 39.41 & 46.87 & 55.74 \\
\hline Total Sales & 3457.04 & 3518.85 & 3577.29 & 3642.65 & 3694.43 & 3904.56 & 4148.39 & 4332.72 & 4635.58 & 4959.60 \\
\hline \multicolumn{11}{|l|}{ Net Energy for Load (billion kwh) 7/ } \\
\hline Gross International Imports & 66.16 & 69.97 & 66.52 & 63.51 & 66.43 & 43.83 & 31.59 & 27.93 & 25.01 & 22.39 \\
\hline Gross International Exports & 15.17 & 20.49 & 20.60 & 20.72 & 20.85 & 18.10 & 12.60 & 7.66 & 6.54 & 5.58 \\
\hline Gross Interregional Electric Imports & 344.15 & 349.16 & 354.91 & 345.25 & 339.87 & 297.96 & 227.27 & 182.35 & 157.90 & 136.73 \\
\hline Gross Interregional Electric Exports & 348.04 & 353.38 & 359.30 & 349.57 & 344.31 & 302.11 & 230.93 & 186.07 & 161.56 & 140.27 \\
\hline Purchases from cogenerators 6 / & 145.72 & 146.71 & 147.73 & 148.82 & 149.85 & 154.24 & 160.68 & 166.71 & 171.67 & 176.78 \\
\hline Util. Generation for Customers & 3488.08 & 3551.68 & 3614.54 & 3680.38 & 3728.97 & 3957.50 & 4206.09 & 4392.48 & 4694.76 & 5017.84 \\
\hline Total Net Energy for Load & 3680.90 & 3743.65 & 3803.80 & 3867.66 & 3919.97 & 4133.33 & 4382.09 & 4575.75 & 4878.69 & 5201.69 \\
\hline
\end{tabular}


Table 73. Electric Power Projections for EMM Region

Unites States Total

\begin{tabular}{|c|c|c|c|c|c|c|c|c|c|c|}
\hline & 2002 & 2003 & 2004 & 2005 & 2006 & 2010 & 2015 & 2020 & 2025 & 2030 \\
\hline \multicolumn{11}{|l|}{$\begin{array}{l}\text { Generation by Fuel Type } \\
\text { (billion kilowatthours) }\end{array}$} \\
\hline Coal & 1973.27 & 2015.32 & 2058.04 & 2076.23 & 2088.90 & 2121.49 & 2200.20 & 2295.73 & 2420.96 & 2553.03 \\
\hline Petroleum & 73.78 & 68.10 & 64.83 & 62.29 & 63.99 & 47.99 & 40.99 & 37.21 & 28.86 & 22.39 \\
\hline Natural Gas & 405.32 & 432.31 & 462.81 & 516.95 & 566.58 & 796.17 & 1085.11 & 1256.23 & 1708.18 & 2322.73 \\
\hline Nuclear & 691.48 & 690.67 & 680.78 & 674.38 & 656.08 & 627.33 & 510.60 & 427.07 & 385.03 & 347.14 \\
\hline Pumped Storage/Other 3/ & -0.92 & -0.92 & -0.92 & -0.92 & -0.92 & -0.92 & -0.92 & -0.92 & -0.76 & -0.63 \\
\hline Renewable 4/ & 359.09 & 360.23 & 363.43 & 366.13 & 369.52 & 381.33 & 386.26 & 393.32 & 401.31 & 409.47 \\
\hline Total Generation & 3502.02 & 3565.71 & 3628.97 & 3695.06 & 3744.15 & 3973.39 & 4222.24 & 4408.63 & 4712.65 & 5037.64 \\
\hline Sales to Customers & 3488.08 & 3551.68 & 3614.54 & 3680.38 & 3728.97 & 3957.50 & 4206.09 & 4392.48 & 4694.76 & 5017.84 \\
\hline Generation for Own Use & 13.95 & 14.03 & 14.43 & 14.68 & 15.18 & 15.88 & 16.15 & 16.15 & 17.96 & 19.98 \\
\hline \multicolumn{11}{|l|}{ Cogenerators } \\
\hline Coal & 51.29 & 51.35 & 51.40 & 51.43 & 51.40 & 51.33 & 51.33 & 51.29 & 51.10 & 50.92 \\
\hline Petroleum & 6.12 & 6.13 & 6.13 & 6.16 & 6.17 & 6.25 & 6.39 & 6.59 & 6.37 & 6.16 \\
\hline Natural Gas & 196.89 & 197.76 & 198.58 & 199.58 & 200.45 & 204.73 & 212.24 & 220.35 & 226.55 & 232.93 \\
\hline Other Gaseous Fuels & 5.76 & 5.82 & 5.84 & 5.93 & 5.97 & 6.24 & 6.80 & 7.32 & 8.88 & 10.78 \\
\hline Renewable & 47.34 & 48.33 & 49.25 & 50.18 & 50.91 & 53.57 & 56.79 & 59.55 & 62.65 & 65.91 \\
\hline Other & 7.92 & 7.93 & 7.93 & 7.95 & 7.95 & 8.00 & 8.08 & 8.17 & 8.28 & 8.40 \\
\hline Total & 315.31 & 317.31 & 319.14 & 321.22 & 322.84 & 330.11 & 341.63 & 353.27 & 363.06 & 373.12 \\
\hline Sales to Utilities & 145.72 & 146.71 & 147.73 & 148.82 & 149.85 & 154.24 & 160.68 & 166.71 & 171.67 & 176.78 \\
\hline Generation for Own Use & 169.59 & 170.60 & 171.41 & 172.40 & 173.00 & 175.87 & 180.95 & 186.56 & 191.40 & 196.36 \\
\hline \multicolumn{11}{|l|}{$\begin{array}{l}\text { End-Use Prices } \\
\text { (1998 cents per kilowatthour) }\end{array}$} \\
\hline Residential & 7.6 & 7.6 & 7.6 & 7.5 & 7.5 & 7.4 & 7.3 & 7.3 & 7.11 & 6.95 \\
\hline Commercial & 6.9 & 6.8 & 6.7 & 6.6 & 6.6 & 6.4 & 6.3 & 6.2 & 5.95 & 5.71 \\
\hline Industrial & 4.3 & 4.2 & 4.1 & 4.1 & 4.1 & 4.0 & 3.9 & 3.8 & 3.72 & 3.59 \\
\hline Transportation & 5.2 & 5.2 & 5.1 & 5.0 & 5.0 & 4.8 & 4.7 & 4.6 & 4.36 & 4.16 \\
\hline All Sectors Average & 6.3 & 6.2 & 6.2 & 6.1 & 6.1 & 6.0 & 5.9 & 5.8 & 5.64 & 5.47 \\
\hline \multicolumn{11}{|l|}{$\begin{array}{l}\text { Price Components } \\
\text { (1998 cents per kilowatthour) }\end{array}$} \\
\hline Capital Component & 3.2 & 3.1 & 3.1 & 3.0 & 3.0 & 2.9 & 2.9 & 2.8 & 2.71 & 2.59 \\
\hline Fuel Component & 1.1 & 1.1 & 1.1 & 1.1 & 1.2 & 1.2 & 1.3 & 1.3 & 1.39 & 1.45 \\
\hline O\&M Component & 1.9 & 1.8 & 1.8 & 1.8 & 1.8 & 1.8 & 1.6 & 1.5 & 1.47 & 1.40 \\
\hline Wholesale Power Cost & 0.1 & 0.1 & 0.1 & 0.1 & 0.1 & 0.1 & 0.1 & 0.1 & 0.09 & 0.08 \\
\hline Total & 6.3 & 6.2 & 6.2 & 6.1 & 6.1 & 6.0 & 5.9 & 5.8 & 5.64 & 5.47 \\
\hline \multicolumn{11}{|c|}{ Fuel Consumption (quadrillion Btu) 8/ } \\
\hline Coal & 20.67 & 21.19 & 21.65 & 21.84 & 21.97 & 22.25 & 22.97 & 23.72 & 25.01 & 26.37 \\
\hline Natural Gas & 4.00 & 4.19 & 4.26 & 4.62 & 4.97 & 6.60 & 8.55 & 9.46 & 11.67 & 14.41 \\
\hline Oil & 0.81 & 0.75 & 0.71 & 0.68 & 0.70 & 0.53 & 0.46 & 0.42 & 0.33 & 0.26 \\
\hline Total & 25.48 & 26.12 & 26.62 & 27.15 & 27.64 & 29.37 & 31.97 & 33.60 & 36.35 & 39.32 \\
\hline \multicolumn{11}{|c|}{ Emissions(million short tons) 9/ } \\
\hline Carbon Dioxide & 2427.04 & 2483.55 & 2532.53 & 2571.59 & 2606.89 & 2714.68 & 2895.78 & 3024.43 & 3239.53 & 3469.93 \\
\hline Sulfur Dioxide & 11.05 & 10.85 & 10.65 & 10.38 & 10.12 & 9.15 & 8.95 & 8.95 & 8.22 & 7.54 \\
\hline Nitrogen Oxide & 5.23 & 5.37 & 5.45 & 5.50 & 5.54 & 5.66 & 5.87 & 5.93 & 5.92 & 5.91 \\
\hline
\end{tabular}

$1 /$ Net summer capability is the steady hourly output that generating equipment is expected to supply to system load (exclusive of auxiliary power), as demonstrated by tests during summer peak demand. Includes electric utilities,

small power producers, and exempt wholesale generators. Nameplate capacity is reported for nonutilities on Form EIA-867, signated by the manufacturer. The nameplate

capacity has been converted to net summer capacity based on historic relationships.

$2 /$ Includes oil-, gas-, and dual-fired capability.

3 / Other includes methane, propane gas, and blast furnace gas, hydrogen, sulfur, batteries, chemicals, fish oil, and spent sulfite liquor.

4/ Includes conventional hydroelectric, geothermal, wood, wood waste, municipal solid waste, other biomass, solar thermal, photovoltaics, and wind power.

5/ Cumulative additions after December 31, 1999.

6/ Cogenerators produce electricity and another form of useful energy (such as steam or heat) through the sequential use of energy.

$7 /$ Generation to meet system load by source.

8/ Includes fuel consumption by electric utilities, small power producers, independent power producers, and exempt wholesale generators. Differs from Electric Generators consumption in Table 2 of the Annual Energy Outlook 2000 and Tables 1 to 10 of the Supplement to the Annual Energy Outlook 2000 due to different definitions of electric generators. 
Table 73. Electric Power Projections for EMM Region Unites States Total

\author{
$2002 \quad 2003 \quad 2004 \quad 2005$ \\ 2006 \\ 2010 \\ 2015 \\ 2020 \\ 2025 \\ 2030 \\ 9/ Estimated emissions from utilities and nonutilities (excluding cogenerators). \\ $\mathrm{O} \& \mathrm{M}=$ Operation and maintenance. \\ $\mathrm{EMM}=$ Electricity market module. \\ Kwh = Kilowatthour. \\ $\mathrm{N} / \mathrm{A}=$ Not applicable \\ Note: Totals may not equal sum of components due to independent rounding. The historical data used for the projections were the most current available as \\ of July 31,1999 \\ The numbers presented for 1998 are estimates and may differ from official EIA data reports. \\ Also, please see EIA data publications and the Short-Term Energy Outlook for the 'latest estimates for 1999. \\ Source: 1998 (except for prices and nonutility data) Energy Information Administration (EIA), Annual Energy Review 1998, DOE/EIA-0384(98) \\ (Washington, DC, July 1999). \\ Other 1998 and projections: EIA, AEO2000 National Energy Modeling System run AEO2K.D100199A
}


Table 76. Renewable Resources Consumption/Displacement by Source for Electricity (Trillion Btu)

\begin{tabular}{|c|c|c|c|c|c|c|c|c|c|c|}
\hline & 2002 & 2003 & 2004 & 2005 & 2006 & 2010 & 2015 & 2020 & 2025 & 2030 \\
\hline \multicolumn{11}{|l|}{ United States } \\
\hline Conventional Hydropower & 3084.42 & 3087.69 & 3089.03 & 3090.33 & 3094.34 & 3089.10 & 3082.99 & 3077.34 & 3037.99 & 2999.15 \\
\hline Geothermal 1/ & 444.67 & 443.78 & 442.88 & 446.43 & 440.04 & 508.83 & 584.46 & 740.15 & 853.78 & 984.86 \\
\hline MSW & 373.87 & 382.94 & 395.29 & 407.64 & 424.37 & 490.13 & 552.74 & 571.41 & 669.57 & 784.60 \\
\hline Biomass 2/ & 108.20 & 108.36 & 124.08 & 135.24 & 147.68 & 181.31 & 162.48 & 167.54 & 210.70 & 264.99 \\
\hline Solar Thermal 3/ & 9.26 & 9.33 & 9.74 & 9.81 & 9.99 & 11.25 & 12.58 & 13.91 & 15.29 & 16.80 \\
\hline Solar Photovoltaic 3/ & 0.59 & 0.96 & 1.33 & 1.81 & 2.31 & 4.70 & 8.87 & 13.41 & 53.34 & 212. \\
\hline Wind & 70.16 & 73.67 & 79.88 & 84.10 & 92.13 & 112.57 & 122.06 & 124.30 & 165.97 & 221.60 \\
\hline
\end{tabular}

$1 /$ Includes hydrothermal resources only (hot water and steam).

2/ Include projections for energy crops beginning in 2010.

3/ Grid connected generation only.

Btu $=$ British Thermal Unit.

MSW = Municipal solid waste.

Notes: Totals may not equal sum of components due to independent rounding. The historical data used for the projections were the most available as of July 31, 1999. At that time, most regional data for 1998 were not available. The numbers presented for 1998 are estimates and may differ from official EIA data reports. Also. please see EIA data publications and the Short-Term Energy Outlook for the latest estimates for 1999.

Source: Energy Information Administration, AEO2000 National Energy Modeling System run AEO2K.D100199A. 
Table 17. Renewable Energy Generating Capability and Generation

(Gigawatts, Unless Otherwise Noted)

\begin{tabular}{|c|c|c|c|c|c|c|c|c|c|c|c|}
\hline & 2001 & 2002 & 2003 & 2004 & 2005 & 2006 & 2010 & 2015 & 2020 & 2025 & 2030 \\
\hline \multicolumn{12}{|c|}{$\begin{array}{l}\text { Electricity Generators (excludes cogenerators) 1/ } \\
\text { Net Summer Capability }\end{array}$} \\
\hline Conventional Hydropower & 77.79 & 77.94 & 78.06 & 78.13 & 78.21 & 78.35 & 78.33 & 78.33 & 78.33 & 78.47 & 78.61 \\
\hline Geothermal 2/ & 3.11 & 3.05 & 2.97 & 2.88 & 2.89 & 2.79 & 2.98 & 3.11 & 3.75 & 3.98 & 4.22 \\
\hline Municipal Solid Waste 3/ & 3.27 & 3.40 & 3.48 & 3.59 & 3.70 & 3.86 & 4.47 & 5.00 & 5.17 & 6.10 & 7.20 \\
\hline Wood and Other Biomass 4/ & 1.87 & 1.94 & 1.96 & 1.99 & 2.01 & 2.05 & 2.41 & 2.71 & 2.93 & 3.29 & 3.70 \\
\hline Solar Thermal & 0.33 & 0.33 & 0.34 & 0.35 & 0.35 & 0.36 & 0.40 & 0.44 & 0.48 & 0.52 & 0.56 \\
\hline Solar Photovoltaic & 0.02 & 0.02 & 0.04 & 0.05 & 0.07 & 0.09 & 0.19 & 0.35 & 0.52 & 1.22 & 2.84 \\
\hline Wind & 2.90 & 3.27 & 3.43 & 3.71 & 3.89 & 4.24 & 5.07 & 5.40 & 5.49 & 6.91 & 8.70 \\
\hline Total & 89.29 & 89.96 & 90.27 & 90.70 & 91.13 & 91.74 & 93.84 & 95.33 & 96.67 & 98.96 & 101.31 \\
\hline \multicolumn{12}{|l|}{ Generation (billion kilowatthours) } \\
\hline Conventional Hydropower & 299.79 & 300.04 & 300.36 & 300.49 & 300.62 & 301.01 & 300.50 & 299.90 & 299.35 & 295.52 & 291.75 \\
\hline Geothermal 2/ & 15.65 & 15.76 & 15.61 & 15.46 & 15.55 & 15.26 & 17.35 & 19.62 & 24.70 & 27.98 & 31.69 \\
\hline Municipal Solid Waste 3/ & 22.50 & 23.37 & 23.93 & 24.71 & 25.48 & 26.52 & 30.63 & 34.55 & 35.71 & 41.85 & 49.04 \\
\hline Wood and Other Biomass 4/ & 11.92 & 12.14 & 12.16 & 13.92 & 15.18 & 16.57 & 20.35 & 18.23 & 18.80 & 23.64 & 29.74 \\
\hline Cofiring & 4.49 & 4.26 & 4.12 & 5.72 & 6.80 & 7.93 & 9.34 & 5.20 & 4.25 & 5.20 & 6.36 \\
\hline Solar Thermal & 0.89 & 0.90 & 0.91 & 0.95 & 0.95 & 0.97 & 1.09 & 1.22 & 1.35 & 1.49 & 1.63 \\
\hline Solar Photovoltaic & 0.05 & 0.06 & 0.09 & 0.13 & 0.18 & 0.22 & 0.46 & 0.86 & 1.30 & 5.19 & 20.64 \\
\hline Wind & 5.97 & 6.82 & 7.17 & 7.77 & 8.18 & 8.96 & 10.95 & 11.87 & 12.09 & 16.14 & 21.56 \\
\hline Total & 356.78 & 359.09 & 360.23 & 363.43 & 366.13 & 369.52 & 381.33 & 386.26 & 393.32 & 401.31 & 409.47 \\
\hline \multicolumn{12}{|l|}{ Cogenerators 5/ } \\
\hline \multicolumn{12}{|l|}{ Net Summer Capability } \\
\hline Municipal Solid Waste & 0.52 & 0.52 & 0.52 & 0.52 & 0.52 & 0.52 & 0.52 & 0.52 & 0.52 & 0.52 & 0.52 \\
\hline Biomass & 6.26 & 6.40 & 6.56 & 6.71 & 6.85 & 6.96 & 7.37 & 7.94 & 8.46 & 9.13 & 9.86 \\
\hline Total & 6.78 & 6.92 & 7.08 & 7.23 & 7.37 & 7.48 & 7.89 & 8.46 & 8.98 & 9.65 & 10.36 \\
\hline \multicolumn{12}{|l|}{ Generation (billion kilowatthours) } \\
\hline Municipal Solid Waste & 3.13 & 3.13 & 3.13 & 3.13 & 3.13 & 3.13 & 3.13 & 3.13 & 3.13 & 3.16 & 3.20 \\
\hline Biomass & 38.36 & 39.23 & 40.19 & 41.07 & 41.96 & 42.63 & 45.06 & 48.28 & 51.02 & 54.77 & 58.80 \\
\hline Total & 41.50 & 42.36 & 43.33 & 44.20 & 45.09 & 45.76 & 48.19 & 51.41 & 54.15 & 57.90 & 61.91 \\
\hline \multicolumn{12}{|l|}{ Other Generators 6/ } \\
\hline Conventional Hydropower 7/ & 1.10 & 1.10 & 1.10 & 1.10 & 1.10 & 1.10 & 1.10 & 1.10 & 1.10 & 1.10 & 1.10 \\
\hline Geothermal & 0.00 & 0.00 & 0.00 & 0.00 & 0.00 & 0.00 & 0.00 & 0.00 & 0.00 & 0.00 & 0.00 \\
\hline Solar Photovolvaic & 0.02 & 0.03 & 0.04 & 0.07 & 0.09 & 0.13 & 0.35 & 0.42 & 0.74 & 2.13 & 6.11 \\
\hline Total & 1.11 & 1.12 & 1.14 & 1.16 & 1.19 & 1.22 & 1.44 & 1.52 & 1.84 & 2.06 & 2.32 \\
\hline \multicolumn{12}{|l|}{ Generation (billion kilowatthours) } \\
\hline Conventional Hydropower 7/ & 4.87 & 4.87 & 4.86 & 4.86 & 4.86 & 4.86 & 4.85 & 4.84 & 4.83 & 4.41 & 4.02 \\
\hline Geothermal & 0.07 & 0.07 & 0.07 & 0.07 & 0.07 & 0.07 & 0.07 & 0.07 & 0.07 & 0.13 & 0.24 \\
\hline Solar Photovolvaic & 0.03 & 0.04 & 0.07 & 0.12 & 0.16 & 0.22 & 0.46 & 0.47 & 0.50 & 1.34 & 3.59 \\
\hline Total & 4.96 & 4.98 & 5.00 & 5.05 & 5.09 & 5.15 & 5.38 & 5.37 & 5.40 & 5.05 & 4.72 \\
\hline
\end{tabular}

1 / Includes all electric power generators except cogenerators, which produce electricity and other useful thermal energy. Includes small power producers and exempt wholesale generators.

2/ Includes hydrothermal resources only (hot water and steam).

3/ Includes landfill gas.

4/ Includes projections for energy crops after 2010.

5 / Cogenerators produce electricity and other useful thermal energy.

6 / Includes small on-site generating systems in the residential, commercial, and industrial sectors used

primarily for own-use generation, but which may also sell some power to the grid.

7/ Represents own-use industrial hydroelectric power.

$\mathrm{N} / \mathrm{A}=$ Not applicable.

Notes: Totals may not equal sum of components due to independent rounding. Data for 1997 and 1998 are model results and may differ slightly from official EIA data reports. Net summer capability has been estimated for nonutility generators for AEO2000. Net summer capability is used to be consistent with electric utility capacity estimates. Additional retirements are determined on the basis of the size and age of the units.

Sources: 1997 and 1998 electric utility capability: Energy Information Administration (EIA), Form EIA-860.

"Annual Electric Generator Report." 1997 and 1998 nonutility and cogenerator capability: EIA, Form

EIA-867, "Annual Nonutility Power Producer Report, 1997." 1997 and 1998 generation: EIA, Annual Energy

Review 1998, DOE/EIA-0384(98) (Washington, DC, July 1999). Projections: EIA, AEO2000 National Energy

Modeling System run AEO2K.D100199A. 


\section{Appendix C Diffusion Curves}




\section{Appendix C \\ Technology Diffusion Models - Application to Selected Energy-Efficient Products for Buildings}

\section{Abstract}

Diffusion models represent the principal forecasting method for determining potential market penetration for products that have not yet been introduced into the marketplace. Because this situation generally applies to the long-term forecasting horizon of technology assessment models, a means to credibly represent price and policy effects in diffusion models is a key factor in improving the usefulness of market assessment studies. The basic diffusion models assume that the cumulative market penetration follows a characteristic time path (usually in the form of an S-shaped curve).

Perhaps the dominant type of diffusion model is the mixed-influence model introduced by Bass (1969). The Bass model incorporates parameters that reflect both external (e.g., mass media communication) and internal influences (e.g., word of mouth). A study was conducted by Pacific Northwest National Laboratory (PNNL) to estimate Bass specification for ten selected energyefficient products in buildings to help assess technologies supported by the U.S. Department of Energy's (DOE's) Office of Building Technology, State and Community Programs (BTS). This appendix summarizes the results of that study.

\section{Scientific and Technical Approach}

A study was conducted by PNNL to examine the historical market penetration for ten energyefficient products related to the building sector. Diffusion models were estimated for each product, based on the specification proposed by Frank Bass (1969). The resulting models are intended to help assess technologies supported by DOE's BTS. This model development and empirical analysis are designed to generate more credible predictions of the adoption process of important energy-efficiency technologies in the buildings sector.

The basic Bass diffusion model, which is possibly the most widely used specification for analyzing market penetration, assumes that the potential market in which the new technology is penetrating is fixed. In reality, the potential market is usually growing in response to a falling price as the manufacturing process and industry structure behind the new technology evolve. This study is aimed toward developing a simple structural model that incorporates these effects and that can be easily estimated from historical data. Given a suitable conceptual model, its parameters can be estimated from data related to several energy technologies.

Most studies of technology adoption have focused either on defining the market potential of the new technology or on the pace by which the technology is adopted. Models that have integrated both aspects generally have not been subjected to historical validation of their underlying parameters. Therefore, in general, little empirical basis exists to suggest which process — diffusion or expanding market potential due to falling costs - might be more influential in driving the penetration of new technologies. 


\section{Background}

A report by the Electric Power Research Institute (EPRI) (1991) provides a good overview of market penetration approaches. Although the report has a slant toward utilities, much of the discussion applies to all types of energy-saving technologies. The report was prepared by the Research Triangle Institute in North Carolina.

The EPRI report clearly distinguishes between two aspects of the process for forecasting market penetration: 1) forecasting market potential, and 2) forecasting the rate of market penetration. Forecasting market potential can involve several different concepts of potential, including maximum, technical, and economic potential.

The EPRI report states that the factors affecting the rate of market penetration are predominantly different from factors affecting market potential. For example, comparative advantage — often determined by economic cost—strongly affects market potential. However, comparative advantage doesn't appear to have as strong an effect on the rate of market penetration.

In trying to distinguish the key factors affecting potential vs. penetration, EPRI suggests that market potential is predominantly influenced by the following:

- the market population and demographic trends

- the needs of the market: customer perceptions, attitudes, and beliefs

- feasibility of the product, which depends on functional characteristics of the product and its economic advantages compared with alternatives.

According to EPRI, the rate of market penetration is predominantly influenced by other factors:

1. marketing effort, such as promotion, advertising, and product positioning

2. product characteristics, such as complexity, compatibility, trialability, and observability

3. characteristics of potential adopters, such as decision-making style, innovativeness, and adoption processes

4. market characteristics, such as macroeconomic conditions, degree of social interaction among potential adopters, and competitive conditions.

Approaches to predicting the diffusion of a new technology general fall under the category of judgmental methods or model-based methods. The judgmental methods share the common trait that they don't require mathematical models or computations; they rely implicitly on the experience and perceptions of the forecaster. On the other hand, model-based methods use wellspecified algorithms to process and analyze data. Thus, the model-based methods can provide systematic forecasts of market penetration that are reproducible and amenable to being incorporated into broader integrated models.

Model-based methods can be divided into two major categories: extrapolation models and causal models. Extrapolation methods have the following: 1) naive diffusion process models, 2) moving average, 3) exponential smoothing, 4) Census Bureau X-11, 5) Box-Jenkins, and 6) Multivariate Time Series. 
Of the extrapolation methods, the diffusion models represent the principal method for dealing with products that have not yet been introduced. Because this situation generally applies to long-range models, the discussion will be restricted to these models.

The diffusion models assume that the cumulative market penetration follows a characteristic time path (usually in the form of an S-shaped curve). An apt analogy is the spread of contagious disease in a fixed population. Once begun, growth of the disease in the number of infected individuals may follow a stable, predictable path. The time path of the infection in the population depends on the probability of spontaneous infection, the share of infected individuals, and probability of uninfected individuals interacting with individuals already infected. The notion underlying the penetration rate models is that information about the new technology sufficient to induce its adoption - is similar to an infectious disease (although with a much more positive connotation). This model provides the rationale behind the S-shaped ("logistic") penetration curves that are often observed.

\section{Bass Diffusion Model}

Perhaps the dominant type of diffusion model is the mixed-influence model introduced by Bass in the late 1960s. This two-parameter model incorporates parameters that reflect both external and internal influences. The external influence (corresponding to the "spontaneous" infection mentioned above) is exemplified by mass media communication, size of sales force, or other structured channels of information. Spontaneous refers to the adopter not being influenced by previous adopters but by advertising or some other "external change-agent."

In contrast, the internal influence is intended to capture interpersonal communication or word of mouth (i.e., the contagious aspect of the disease analogy above). This also termed the "imitative effect"; the decision to adopt is made only after being influenced by prior adopters.

The basic specification of the Bass model is as follows:

$$
\mathrm{dN}(\mathrm{t}) / \mathrm{dt}=[\mathrm{p}+\mathrm{q} / \mathrm{MN}(\mathrm{t})][\mathrm{M}-\mathrm{N}(\mathrm{t})]
$$

where

$$
\begin{aligned}
\mathrm{N}(\mathrm{t}) & =\text { cumulative number of adoptions at time } \mathrm{t} \\
\mathrm{M} & =\text { market potential, a constant } \\
\mathrm{p} & =\text { the coefficient of innovation or external influence } \\
\mathrm{q} & =\text { the coefficient of imitation or internal influence. }
\end{aligned}
$$

Equation (1) states that the rate of change in the cumulative number of adopters $(\mathrm{dN}(\mathrm{t}) / \mathrm{dt})$ is proportional to the difference between the market potential $\mathrm{M}$ and the number of previous adopters. The proportionality factor $[\mathrm{p}+\mathrm{q} / \mathrm{M} \mathrm{N}(\mathrm{t})]$ can be interpreted as the probability of adoption at time $t$. This probability is composed of two components: $p$ is interpreted as the probability of spontaneous adoption. The term $[\mathrm{q} / \mathrm{M} \mathrm{N}(\mathrm{t})]$ relates to the probability that adoption will be chosen based on the influence of previous adopters. This probability grows as the number of adopters increases.

To simplify the presentation, Equation (1) can be reoriented in terms of the fraction of the market that is being penetrated rather than the absolute number of adopters. In this case, the market potential can be defined as 1.0. This simplified expression in Equation (2) below now relates to the change in relative cumulative adoptions: 


$$
\mathrm{dF}(\mathrm{t}) / \mathrm{dt}=[\mathrm{p}+\mathrm{qF}(\mathrm{t})][1-\mathrm{F}(\mathrm{t})]
$$

The number of cumulative adoptions at any time, $t$, can be solved by specifying an initial condition that the number of adopters at $t=0$ is 0 . This solution is as follows:

$$
\mathrm{F}(\mathrm{t})=\frac{1-\exp [-(p+q) t]}{1+q / p \exp ([-(p+q)] t]}
$$

The basic diffusion models therefore separate the issue of market penetration rate from market potential. That is why the model in Equation (3) can be compared across technologies - the percentage change in the total penetration does not depend on the size of the market but only on the parameters $\mathrm{p}$ and $\mathrm{q}$.

\section{Estimation Issues}

Issues related to the appropriate estimation procedures for the Bass diffusion model spawned a considerable literature up through the mid-1980s. At least four estimation procedures were proposed by various researchers: 1) ordinary least squares (Bass 1969), 2) maximum likelihood estimators (Schmittlein and Mahajan 1982), 3) nonlinear least squares (Srinivasan and Mason 1986) and Jain and Rao (1989), and 4) algebraic estimation (Mahajan and Sharma 1986).

Mahajan, Mason, and Srinivasan (1986) performed a comparative study of estimation procedures using penetration data for seven products. They concluded that the maximum likelihood and nonlinear least squares procedures provided the best predictions of the four procedures considered. Between those two procedures, nonlinear least squares provided slightly better predictive performance and more valid estimates of the standard errors for the parameter estimates.

As preliminary analysis, the authors looked at three variants of nonlinear least squares model. For the first two variants, the focus is on the number of adopters (X) in each period. Taking the differences of Equation (3) above and including a separate parameter to reflects the total number of adopters $(\mathrm{m})$ results in the following for the first variant:

$$
\mathrm{X}(\mathrm{i})=\underset{1+(\mathrm{q} / \mathrm{p}) \exp \left[-(\mathrm{p}+\mathrm{q}) \mathrm{t}_{\mathrm{i}}\right]}{\left[1-\exp \left(-(\mathrm{p}+\mathrm{q}) \mathrm{t}_{\mathrm{i}}\right]\right.} \quad-\quad \mathrm{m}\left[\frac{1-\exp \left(-(\mathrm{p}+\mathrm{q}) \mathrm{t}_{\mathrm{i}-1}\right]}{1+(\mathrm{q} / \mathrm{p}) \exp \left[-(\mathrm{p}+\mathrm{q}) \mathrm{t}_{\mathrm{i}-1}\right]}+\mathrm{u}_{\mathrm{i}}\right.
$$

Jain and Rao (1989) suggest that that the formulation in (4) gives the ex ante value for X(i) and does not use the ex post information on $\mathrm{X}(1), \mathrm{X}(2), \ldots, \mathrm{X}(\mathrm{I}-1)$. In the Bass model, the probability that an individual who has not purchased the product up to period $\mathrm{t}_{\mathrm{i}-1}$ is given by $\left[\mathrm{F}\left(\mathrm{t}_{\mathrm{i}}\right)-\mathrm{F}\left(\mathrm{t}_{\mathrm{i}-}\right.\right.$ $\left.\left.{ }_{1}\right)\right] /\left(\left(1-\mathrm{F}\left(\mathrm{t}_{\mathrm{i}-1}\right)\right]\right.$. Thus, the number of adopters in the $i$ th time interval is as follows:

$$
\mathrm{X}(\mathrm{i})=\left(\mathrm{m}-\mathrm{N}\left(\mathrm{t}_{\mathrm{i}-1}\right)\right)\left[\mathrm{F}\left(\mathrm{t}_{\mathrm{i}}\right)-\mathrm{F}\left(\mathrm{t}_{\mathrm{i}-1}\right)\right] /\left(\left(1-\mathrm{F}\left(\mathrm{t}_{\mathrm{i}-1}\right)\right]+\mathrm{vi}\right.
$$

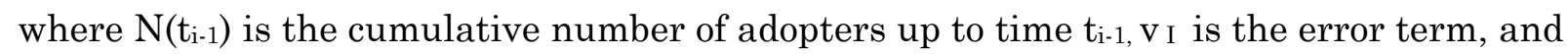
cumulative distribution function is given by Equation (3). This ex post estimation procedure proposed by Jain and Rao uses the actual number of cumulative adoptions in the estimation, as compared to the predicted number in Equation (4). Thus, it is termed the ex post estimation in contrast to the ex ante estimation. 
Mahajan, Mason, and Srinivasan also point out the possibility of estimating the diffusion curve in level rather than differences form (e.g., cumulative sales rather than annual sales). Thus, the cumulative number of adopters is the dependent variable and the specification becomes

$$
\begin{aligned}
& \mathrm{N}(\mathrm{ti})=\mathrm{mF}(\mathrm{t})=\mathrm{m}[\underline{1-\exp [-(\mathrm{p}+\mathrm{q}) \mathrm{t}]}]+\mathrm{wi} \\
& {[1+q / p \exp ([-(p+q)] t]}
\end{aligned}
$$

As Mahajan, Mason, and Srinivasan (1986) indicate, the errors in Equation (6) are likely to be heteroscedastic (i.e., error variance increasing with i) and autocorrelated. Nevertheless, this formulation is somewhat more stable than the differences form and sometimes yields more plausible estimates.

\section{Results}

The results of estimating the Bass diffusion model for ten energy-related technologies are described below. The technologies were placed into four separate categories: 1) lighting, 2) HVAC and refrigeration (HVAC/R), 3) envelope, and 4) other. Table 1 summarizes the technologies for which Bass diffusion models were estimated.

Table 1. Summaries of Technologies Analyzed

\begin{tabular}{|l|c|c|l|}
\hline Technology & Start Year & End Year & \multicolumn{1}{|c|}{ Market Definition } \\
\hline Lighting: & 1986 & 1997 & Corrected power-factor ballasts \\
\hline Electronic ballast & 1986 & 1994 & Incandescent, 15-150 watt \\
\hline Compact fluorescent & 1986 & 1994 & Fluorescent lamps, >30 watt \\
\hline T-8 lamps & 1970 & 1995 & Residential furnaces \\
\hline HVAC and Refrigeration: & 1975 & 1987 & All oil burners \\
\hline Electric Heat Pump & 1982 & 1997 & Gas furnaces \\
\hline Flame retention burner & 1982 & 1995 & No. of supermarkets \\
\hline Condensing gas furnace & 1949 & 1961 & No. of households \\
\hline Advanced Compressor & 1983 & 1996 & Residential windows \\
\hline Room Air Conditioners & 1984 & 1994 & Commercial buildings designed \\
\hline Envelope Technologies: &
\end{tabular}

In most of the cases, the technology was not assumed to ultimately capture all of the market, as defined in the third column of the table. The maximum market potential was judgmentally determined, on the basis of inspection of the data or from other sources.

Table 2 presents the results of the estimation work. The parameter sets labeled in bold are those judged as the most preferred, based on the reasonableness of the estimates and statistical significance. At this point, estimates based on annual adoptions have been used. The annual adoption rates are expressed as a fraction of the total potential market and the maximum fraction of the total market potential is expressed exogenously. The first and third groups of estimates reflect an effort to allow the data to suggest the maximum market potential ( $\mathrm{m}$ rather than $\left.\mathrm{m}^{*}\right)$.

Examining the estimated coefficients indicates that the estimates of the external influence parameter are much more variable than those for the internal influence parameter. One of the lowest values of the internal influence coefficient is found for compact fluorescent lamps, which 
Table 2. Diffusion Curve Parameter Results

\begin{tabular}{|c|c|c|c|c|c|c|c|c|c|c|c|c|}
\hline \multirow[t]{2}{*}{ Product } & \multicolumn{6}{|c|}{ Annual Sales } & \multicolumn{6}{|c|}{ Cumulative Sales } \\
\hline & $\mathbf{p}$ & $\mathbf{q}$ & $\mathbf{m}$ & $\bar{p}$ & $\mathbf{q}$ & $\mathrm{m}^{*}$ & $\mathbf{p}$ & $\mathbf{q}$ & $\mathbf{m}$ & $\bar{p}$ & $\mathbf{q}$ & $\mathbf{m}^{*}$ \\
\hline Electronic ballasts & $\begin{array}{l}.0054 \\
(0.6) \\
\end{array}$ & $\begin{array}{l}.6489 \\
(2.5) \\
\end{array}$ & $\begin{array}{l}.4815 \\
(3.4) \\
\end{array}$ & $\begin{array}{l}.0138 \\
(1.1) \\
\end{array}$ & $\begin{array}{l}.3729 \\
(3.3) \\
\end{array}$ & 0.6 & $\begin{array}{l}.0037 \\
(2.1) \\
\end{array}$ & $\begin{array}{l}.7006 \\
7.3) \\
\end{array}$ & $\begin{array}{l}.4627 \\
(19.5) \\
\end{array}$ & $\begin{array}{l}.0092 \\
(3.3) \\
\end{array}$ & $\begin{array}{l}439 \\
9.3) \\
\end{array}$ & 0.6 \\
\hline $\begin{array}{l}\text { Compact } \\
\text { Fluorescent } \\
\end{array}$ & & & & .0075 & .071 & 0.50 & & & & & & \\
\hline T-8 Lamps & & & & .0041 & .326 & 0.80 & & & & & & \\
\hline Electric Heat Pump & & & & .0118 & 0.459 & 0.23 & $\begin{array}{l}.0054 \\
(1.6) \\
\end{array}$ & $\begin{array}{c}.6228 \\
5.9) \\
\end{array}$ & $\begin{array}{l}.2169 \\
(43.9)\end{array}$ & $\begin{array}{l}.0112 \\
(2.2) \\
\end{array}$ & $\begin{array}{l}.4588 \\
(6.3) \\
\end{array}$ & .23 \\
\hline $\begin{array}{l}\text { Flame retention } \\
\text { burner }\end{array}$ & & & & .0039 & 0.655 & 1.0 & $\begin{array}{l}<.001 \\
(0.3)\end{array}$ & $\begin{array}{l}1.774 \\
(3.7)\end{array}$ & $\begin{array}{l}.8143 \\
(23.9)\end{array}$ & $\begin{array}{l}.0040 \\
(1.1)\end{array}$ & $\begin{array}{l}.655 \\
(4.6)\end{array}$ & 1.0 \\
\hline $\begin{array}{l}\text { Condensing gas } \\
\text { furnace }\end{array}$ & & & & $\begin{array}{l}.070 \\
(1.8) \\
\end{array}$ & $\begin{array}{l}.071 \\
(0.8) \\
\end{array}$ & 0.3 & $\begin{array}{l}.0782 \\
(3.6) \\
\end{array}$ & $\begin{array}{l}.2082 \\
(1.8) \\
\end{array}$ & $\begin{array}{r}.238 \\
(14.7) \\
\end{array}$ & $\begin{array}{l}.0881 \\
(6.1) \\
\end{array}$ & $\begin{array}{l}.0240 \\
(0.6) \\
\end{array}$ & 0.3 \\
\hline $\begin{array}{l}\text { Room air } \\
\text { conditioners }\end{array}$ & & & & .0072 & .423 & 0.33 & & & & & & \\
\hline $\begin{array}{l}\text { Advanced } \\
\text { compressors }\end{array}$ & $\begin{array}{l}.0232 \\
(9.6) \\
\end{array}$ & $\begin{array}{l}.2788 \\
(11.3) \\
\end{array}$ & $\begin{array}{l}.9514 \\
(21.3)\end{array}$ & $\begin{array}{l}0.247 \\
(11.2) \\
\end{array}$ & $\begin{array}{r}.2483 \\
(22.1) \\
\end{array}$ & 1.0 & $\begin{array}{r}.0242 \\
(31.4) \\
\end{array}$ & $\begin{array}{l}.2633 \\
(20.5) \\
\end{array}$ & $\begin{array}{l}.9801 \\
(39.8)\end{array}$ & & & \\
\hline Low-E windows & $\begin{array}{l}.0562 \\
(8.2)\end{array}$ & $\begin{array}{l}.2936 \\
(7.3)\end{array}$ & $\begin{array}{l}.3663 \\
(18.3)\end{array}$ & $\begin{array}{l}.0577 \\
(9.6)\end{array}$ & $\begin{array}{l}.2729 \\
(14.3)\end{array}$ & 0.37 & & & & $\begin{array}{l}.0565 \\
(25.0)\end{array}$ & $\begin{array}{l}.2819 \\
(27.3)\end{array}$ & 0.37 \\
\hline $\begin{array}{l}\text { DOE-2 Building } \\
\text { Model }\end{array}$ & $\begin{array}{c}.00001 \\
(0.5) \\
\end{array}$ & $\begin{array}{l}1.18 \\
(4.8) \\
\end{array}$ & $\begin{array}{l}.279 \\
(6.4) \\
\end{array}$ & .0005 & .656 & .50 & & & & & & \\
\hline
\end{tabular}

reflect their extremely slow penetration into the market to date. (In addition to their high initial price, Haddad [1994] suggests that industrial organization, retail incentives, and social convention are additional reasons for the atypically slow adoption of this technology.) On the other extreme is the flame retention oil burner, whose adoption was accelerated by the increase in oil prices during the Iranian revolution in the late 1970s. In spite of these extremes, the simple average internal influence coefficient of 0.38 is the same as the average for 213 technologies as reported by Sultan, Farley, and Lehmann (1990). In that study, the average external influence was 0.03 , compared with an average 0.018 for the ten energy-related technologies.

\section{References}

Bass, F.M. 1969. "A New Product Growth Model for Consumer Durables" Management, Vol. 15 (January 1969), pp. 215-227.

Electric Power Research Institute (EPRI). 1991. Market Penetration of New Technology, Programs and Sciences, EPRI CU-7011, February 1991.

Haddad, B. M. 1994. "Why Compact Fluorescent Lamps Are Not Ubiquitous: Industrial Organization, Incentives, and Social Convention", in Proceeding of the ACEEE 1994 Summer Study on Energy Efficiency in Buildings, Vol. 10, pp. 77-84. American Council for an EnergyEfficient Economy, Washington D.C. 
Mahajan, V., C. Mason, and V. Srinivisan. 1986. "An Evaluation of Estimation Procedures for New Product Diffusion Models." In Innovation Diffusion Models of New Product Acceptance, V. Mahajan and Y. Wind, eds., Cambridge, MA: Ballanger.

Mahajan, V. and S. Sharma. December 1986. "A Simple Algebraic Estimation Procedure for Innovation Diffusion Models," Technological Forecasting and Social Change. 30:331-45.

Schmittlein, D.C. and V. Mahajan. 1982. "Maximum Likelihood Estimation for an Innovation Diffusion Model of New Product Acceptance," Marketing Science. 1(Winter): 57-78.

Sultan, F., J.U. Farley, and D.R. Lehmann. 1990. "A Meta-Analysis of Applications of Diffusion Models," Journal of Marketing Research, Vol. XXVII (February 1990), pp. 70-77.

Srinivzsan, V. and C. Mason 1986. "Nonlinear Least Squares Estimation of New Product Diffusion Models,” Marketing Science. 5 (Spring):169-78.

\section{Bibliography}

Gilshannon, S.T. and D.R. Brown. 1996. Review of Methods for Forecasting the Market Penetration of New Technologies, PNNL-11428, Pacific Northwest National Laboratory.

Kamakuru, W.A. and S.K. Balasubramanian. 1988. "Long-Term View of the Diffusion of Durables," International Journal of Research in Marketing, Vol. 5, pp. 1-13.

Mahajan, V., E. Muller, and F. Bass. January 1990. "New Product Diffusion Models in Marketing: A Review and Directions for Research," Journal of Marketing, Vol. 54:1-26.

Roberts, G.F. and D.L. Greene. January/February 1983. "A Method for Assessing the Market Potential of New Energy-Saving Technologies," In IEEE Transactions on Systems, Man, and Cybernetics, Vol. SMC-13, No. 1.

Stoneman, P. 1987. The Economic Analysis Technology Policy. Oxford: Clarendon Press.

Teotia, A.P.S. and P.S. Raju. December 1986. "Forecasting the Market Penetration of New Technologies Using a Combination of Economic Cost and Diffusion Models," Journal of Product Innovation Management, 3:225-237.

Thomas, R.J. 1985. "Estimating Market Growth for New Products: An Analogical Diffusion Model Approach." Journal of Product Innovation Management, Vol. 2, pp. 45-55.

\section{List of Terms}

BTS Office of Building Technology, State and Community Programs

DOE U.S. Department of Energy

EPRI Electric Power Research Institute

PNNL Pacific Northwest National Laboratory 


\section{Appendix D Methodology}




\section{Appendix D \\ GPRA Metrics Methodology}

This appendix describes the calculation methodology used within the Building Energy Savings Estimation Tool (BESET) and the National Energy Modeling System (NEMS) to estimate the energy savings for programs in the following decision units:

- Community Energy Program

- Energy Star Program

- Residential Buildings Integration

- Commercial Buildings Integration

- Equipment, Materials, and Tools.

The programs in the other three decision units, State Energy Program, Weatherization Assistance Program, and Technology Roadmaps and Competitive R\&D, were calculated within spreadsheets using the inputs outlined in the main report for these appendixes - Documentation for FY 2002 BTS GPRA Metrics.

Because of the number and length of the tables in this appendix, all the tables are shown at the end of the discussion.

\section{Methodology for Whole-Building Programs}

This section addresses programs that target the building envelope, a whole-building design approach, or the total building system and that are modeled as improvements to the building envelope. Envelope programs are characterized by a reduction in space conditioning and water heating load from changes in the building system or envelope. The following programs in the U.S. Department of Energy's (DOE's) Office of Building Technology, State and Community Programs (BTS) are characterized by the whole-building approach:

- Rebuild America (in Community Energy Program decision unit)

- Residential Buildings R\&D (in Residential Buildings Integration decision unit)

- Commercial Buildings R\&D (in Commercial Buildings Integration decision unit)

- Analysis Tools and Design Strategies (in Equipment, Materials, and Tools decision unit).

This section uses the FY 2001 Residential Buildings R\&D program to illustrate the calculation methodology. The steps below are involved in calculating the energy savings associated with the Residential Buildings R\&D program and are discussed in the next subsections:

- Determine the size of the potential market.

- Determine the number of units affected by the BTS program.

- Determine the base space conditioning and water heating end-use loads.

- Determine the space conditioning and water heating end-use loads after program implementation.

- Calculate the energy savings. 


\section{Determine Size of the Potential Market}

The Residential Building R\&D program targets new residential construction. The size of this potential market is shown in Table D.1 and is part of the baseline assumptions (see Appendix A). Table D.1 shows the new residential building stock, in millions of households, for the north and south regions. The stock of new buildings is defined as those built within the year, not the total new building stock (all buildings built since 2001). The last row of the table represents the cumulative new building stock total (all buildings built since 2001).

\section{Determine Number of Units Affected by the BTS Program}

The number of units affected by the BTS program is calculated using the program penetration rates (Table D.2) and the building stock (Table D.1). The penetration rates are applied to the appropriate market segment to compute the number units impacted by the BTS program (see Table D.3). For the new building stock, this figure represents the number of impacted housing units within that year, not the cumulative number. Because energy savings are accumulated over time - a housing unit impacted by the BTS program in 2001 will continue to save energy throughout its life - the number of impacted units must be summed to represent the total number of impacted housing units in the given year (see Table D.4). Therefore, the total number of impacted units listed for single-family houses for 2005 in Table D.3 (.016) represents the number built between 2004 and 2005 that are impacted by the BTS program, while the corresponding number in Table D.4 (.040) represents the number of units impacted since the program was implemented or 2001, whichever is later.

Some envelope programs affect the existing building stock, unlike the Residential Building R\&D program. The existing building stock is defined as the total stock in 2001 that survive in each subsequent year. The penetration into that building stock therefore represents the cumulative number of units to that time period, negating the need to accumulate the number of installed units.

\section{Determine Base Space Conditioning and Water Heating End-Use Loads}

The end-use loads for heating, cooling, and water heating for new residential buildings are shown in Table D.5 and are part of the baseline assumptions (see Appendix A). The performance improvements for envelope programs are characterized by reductions in the space conditioning and water heating loads. Therefore, the base energy consumption does not have to be explicitly calculated. Instead, the load reduction is applied to the base load to determine the new load; and the resulting difference in loads is used to calculate energy savings.

\section{Determine Space Conditioning and Water Heating End-Use Loads After Program Implementation}

The performance inputs for envelope programs are defined in terms of percent load reductions. Table D.6 presents the percent load reductions for the Residential Building R\&D program.

The load reductions are applied to the corresponding end-use load segment to determine the building-level load reductions by end use, presented in Table D.7. The building-level load reductions are translated into aggregate load reductions by region by multiplying the 
calculated building-level load reductions (in absolute terms, KBtu/sq ft or MMBtu/ household) by cumulative installed units for that region (given in Table D.4). Tables D.8 and D.9 present the regional load reductions by end use.

\section{Calculate Energy Savings}

The regional load reductions must be translated into regional energy savings. To do this, baseline assumptions regarding existing equipment efficiencies and existing equipment market shares are used. First, the regional load reductions are divided by the baseline existing equipment efficiencies (listed in Table D.10), which yields potential energy savings by equipment type and end use, as shown in Table D.11.

The potential energy savings assume that each equipment type has $100 \%$ of the market, so the actual equipment market shares must then be applied. Table D.12 shows the existing baseline equipment market shares. The market share for each equipment type is multiplied by the potential energy savings calculated in Table D.11 to determine the actual energy savings, as shown in Table D.13.

The savings calculated in Table D.13 are aggregated by fuel type to determine the total delivered electric savings, total primary electric savings (equal to total delivered electricity multiplied by electricity conversion factor that varies by year), total natural gas savings, total oil savings, and total primary savings. Table D.14 presents the energy savings.

\section{Equipment and Standards - General Methodology Using the National Energy Modeling System}

Most of the programs in the Equipment, Materials, and Tools decision unit target specific types of equipment within a building or standards directed toward the usage of specific equipment. Equipment programs are characterized by new equipment efficiencies and are compared with "baseline" efficiencies to calculate energy savings. To determine the penetration of the BTS equipment relative to the more conventional equipment, the National Energy Modeling System (NEMS) for the Energy Information Administration's (EIA's ) Annual Energy Outlook (AEO 2000) has been used as part of the FY 2002 GPRA metrics to estimate the energy savings of various BTS equipment programs.

The NEMS commercial and residential demand modules generate forecasts of energy demand (energy consumption) for the commercial and residential sectors. The commercial demand module generates fuel consumption forecasts for electricity, natural gas, and distillate fuel oil. These forecasts are based on energy prices and macroeconomic variables from the NEMS system, combined with external data sources. The residential model uses energy prices and macroeconomic indicators to generate energy consumption by fuel type and census division in the residential sector. The commercial and residential demand modules are described in the following subsections.

\section{Commercial Demand}

This module includes assembly, education, food service, food sales, health care, lodging, mercantile/service, and office buildings. Commercial energy demand within NEMS is calculated in four basic steps. The first step is to forecast commercial sector floorspace. The second step is 
to forecast energy services such as space conditioning equipment, lighting, water heating, and refrigeration. The third step is to select specific technologies to meet the demand of energy services. This step involves modeling consumer behavior and capturing the decision between such equipment as incandescent lights and fluorescent lights. The final step involves determining how much energy will be consumed by the equipment chosen to meet the demand for energy services.

This third step is a key element in calculating the estimated energy savings of a given technology promoted by a particular BTS program. Within this step, consumers are assumed to purchase energy-using equipment to meet three types of service demands: services for new buildings, replacement of old equipment that is at the end of its technical life, and replacement of old equipment that is at the end of its economic life (although it still may be technically viable). The NEMS commercial model is coded to allow the use of several possible assumptions about consumer behavior to model this decision process. The assumptions are designed to represent empirically the range of economic factors that most influence the consumer's decision and include the following:

1. Consumer buys the equipment with the minimum life-cycle cost.

2. Consumer buys equipment that uses the same fuel as existing and retiring equipment but minimizes costs across technologies using that fuel.

3. Consumer buys (or keeps) the same technology as the existing and retiring equipment but chooses among different efficiency levels based on minimum life-cycle cost.

The model is designed to choose among a discrete set of technologies that are exogenously characterized by commercial availability, capital costs, operating and maintenance costs, efficiencies, and lifetime. For GPRA metrics, the menu of equipment may be altered to include relevant BTS program equipment, technological innovations, and standards. The NEMS design can accommodate a changing menu of technology choices, recognizing that changes in energy prices and consumer demand may significantly change the set of relevant technologies that the model user wishes to consider.

\section{Residential Demand}

The residential sector demand module includes single-family, multifamily, and mobile home dwellings. Residential energy demand is modeled using a sequence of five steps. The first step is to forecast housing stock. The second step is to select the specific technologies to meet the demand for each energy service (e.g. furnaces and heat pumps). The third step is to forecast appliance stocks that are required by each end-use service. The fourth step is to forecast changes in building-shell integrity. Building-shell efficiency in new construction is assumed to improve over the forecast period because of stricter building codes and other efficiency programs and may fluctuate in response to fuel price changes from the base year. The final step is to calculate the energy consumed by the equipment chosen to meet the demand for energy services.

As with the commercial model, the GPRA metrics methodology involves modifying the technology performance and cost inputs to reflect the BTS-developed equipment. The technology and equipment selection simulates the behavior of residential consumers based on the relative importance of life-cycle costs, capital costs, and operating costs of competing technologies within a service. Decisions on new and replacement equipment reflect additional factors beyond the traditional life-cycle cost methodology, including space heating fuel choice and previous 
equipment choices. The technology and equipment selection allocates end-use services based on a defined equipment menu of the various technologies and fuels that compete in the market.

\section{Methodology for Specific Energy Star Programs}

This section covers the methodological approach to calculating energy savings for the programs related to the following types of equipment:

- water heaters (Energy Star gas and electric water heaters)

- refrigerators (Energy Star refrigerators)

- clothes washers (Energy Star clothes washers)

- air conditioners (Energy Star room air conditioners)

- dishwashers (Energy Star dishwashers).

The modifications to the NEMS input file (RTEKTY) for each appliance with an Energy Star program are described below. The baseline assumptions made by EIA, the changes in the Beta1 coefficients, and the resulting changes in the market shares for the most energy-efficient products are documented. For a few appliances, some changes were made in the baseline assumptions made by EIA; the reasons for these changes are briefly discussed.

\section{Data Input Modifications for Energy Star Refrigerators}

Baseline Modifications. EIA uses four separate models to represent the range of energy efficiencies in the refrigerator market. The first three models are conventional top-mount freezer models with a total capacity of 18 cubic feet. The fourth model is a through-the-door model (for water and ice) and does not compete with the first three models. The market share of the through-the-door model is a constant $27 \%$ over the forecast horizon. A review of Arthur D. Little's (ADL's) (1998) efficiency and cost forecasts, as well as a recent paper from Oak Ridge National Laboratory (ORNL) (Vineyard and Sand 1998), suggests some changes to EIA's assumptions used in the $A E O 2000$ projection are warranted.

As part of the EIA forecast, an assumption is made that the 2001 standard (Model 1) yields no increase in cost. Table D.15 shows the EIA efficiency and cost assumptions. This assumption appears to contradict some of the ADL findings. The ADL performance/cost characteristics information suggests that a $460-\mathrm{kWh} / \mathrm{yr}$ unit would have an installed cost of $\$ 580$ to $\$ 700$. To be conservative, an installation cost of $\$ 600$ could be assumed. Because a $478-\mathrm{kWh} / \mathrm{yr}$ unit is nearly as efficient as the $460-\mathrm{kWh} / \mathrm{yr}$ unit, one would expect it would be only negligibly less expensive. Using this logic, the cost of the $478-\mathrm{kWh} / \mathrm{yr}$ unit is assumed to be about $\$ 580$. These revised assumptions are included in Table D.16.

The ADL report suggests that a 460-kWh/yr model represents a typical model after 2002. A highefficiency model is specified to consume $400 \mathrm{kWh}$ per year. However, this specification is for a 20 -cubic-foot model rather than 18 cubic feet. ADL suggests a cost differential of $\$ 100$ to $\$ 120$ between these two models.

The 1998 paper by ORNL's Vineyard and Sand (1998) adds some support to this revision in the cost structure. Vineyard and Sand start with a "1996 model baseline unit" of 20 cubic feet that uses $613 \mathrm{kWh} / y e a r$. The baseline is already 16\% more efficient than the 1993 standard (2.01 kWh/day) resulting from the National Appliance Energy Conservation Act. From this baseline, 
Vineyard and Sand focus on two high-efficiency designs. The most aggressive design would reduce energy by $273 \mathrm{kWh} / \mathrm{yr}$ at a retail cost increase of about $\$ 270$. A more cost-effective unit would consume $1.16 \mathrm{kWh} /$ day $(423 \mathrm{kWh} / \mathrm{yr})$ at a projected cost increase of $\$ 106$.

Given this information, the resulting estimated cost increase of $\$ 100$ between the 460 - and 400$\mathrm{kWh}$ /day units appears to be more reasonable (see Table D.16) than EIA's incremental cost of $\$ 150$. The ORNL baseline unit is less efficient than the 2001 standard and achieves a $30 \%$ energy reduction with a little more than a $\$ 100$ cost increase. This suggests that the $13 \%$ efficiency improvement (460 to 400) between models 2 and 3 could be achieved for $\$ 100$ or less.

Modeling. The two parameters are labeled by EIA as Beta1 and Beta2. Beta1 is used as multiplicative factor with the initial cost of the appliance. Beta2 is used to multiply the annual energy cost. The sum of the two products (i.e., Beta 1 * initial cost + Beta 2 * operating cost) is used in the logit specification to yield market shares for each technology. The Beta1 and Beta2 coefficients are contained with the cost and efficiency data inputs in the file RTEKTY.

As a rough approximation, the ratio of Beta1/Beta2 can be interpreted as the consumer discount rate for the specific appliance. In the residential NEMS module, the Beta1 and Beta2 coefficients vary among appliances, as do the resulting discount rates. For example, the implied discount rates for refrigerators are $16 \%$. On the other hand, the discount rate is estimated to be over $80 \%$ for electric water heaters.

The EIA used the parameters -0.0229 (Beta1) and -0.1207 (Beta2) to reflect the discount rate used by consumers in evaluating various refrigerators are. This translates into approximately a 19\% discount rate (Beta1/Beta2).

For modeling purposes, the focus of the Energy Star program is assumed to increase the market share of the $400-\mathrm{kWh} / \mathrm{yr}$ refrigerator. This unit is about $16 \%$ more efficient than a unit meeting the most recent national standard. To generate a larger market share for this model, the Beta1 coefficient was changed to -0.0055 .

The NEMS residential model does not automatically produce an output table that displays the shares of individual appliances with different efficiencies. These shares are computed within the model for each building type (single family, multifamily, and mobile home) and by the nine census divisions. The NEMS-BTS model was modified to display the shares for the single-family market segment for three separate years: 2005, 2010, and 2020. The results from NEMS for 2005 and 2010 are shown in Table D.17.

\section{Energy Star Clothes Washers}

Modeling the energy savings clothes washers is complex because energy savings can be achieved by reducing the consumption of the motor, reducing hot water use, or reducing dryer use. The most efficient new technology is the horizontal-axis design, which achieves the bulk of its energy savings by the reduction in hot water use.

The residential NEMS input file (RTEKTY) includes a column of factors that relates to hot water. The (unit less) factors can be used to adjust the hot water load associated with clothes washers and dishwashers. In preliminary model runs, the values associated with clothes washers appeared to be too low compared with the information supplied by Lawrence Berkeley National Laboratory (LBNL) in support of an efficiency standard for clothes washers. These 
factors were adjusted from 0.67 to 2.00 for vertical-axis machines. The coefficient for the horizontal-axis machine was increased from 0.24 to 0.40 . The value for the vertical axis machine was estimated by making runs of the model with and without any hot water and observing the resulting energy consumption. The LBNL analysis suggests that $80 \%$ to $90 \%$ of the energy consumption of clothes washers is attributable to water heating. Table D.18 shows the original and revised NEMS inputs for clothes washers.

For the Energy Star program, the discount rate was adjusted to achieve larger shares for the more efficient vertical axis machine as well as the horizontal axis machine. In the baseline run, horizontal axis machines had zero market shares (thus, the model is not consistent with current sales information that shows that these machines are being sold in limited numbers.) The goal of the GPRA exercise was to increase the market share of these machines to $8 \%$ to $10 \%$ of the market. This result was roughly achieved by reducing the Beta1 coefficient in the model from 0.03811 to 0.0101 . Table D.19 shows the results of the NEMS model runs for clothes washers.

\section{Energy Star Hot Water Heaters}

Separate sets of NEMS runs were made for electric water heaters and gas water heaters to model the effects of Energy Star programs.

Electric Water Heater. The key NEMS used by EIA for the AEO 2000 are shown in Table D.20. With these assumed costs, the model projects a zero share for heat pump water heaters.

The Energy Star program was assumed to target high-efficiency electric water heaters whose efficiencies exceed 0.9. As shown in Table D.20, two such units are shown, with efficiencies of 0.95 and 0.96. By 2005, the installed cost of the high-efficiency unit (at the 0.96 efficiency level) is assumed to fall to $\$ 475$.

The logit parameters in the NEMS model related to the choice of electric water heaters are 0.01619 (Beta1) and -0.01952 (Beta2), implying a discount rate of about $83 \%$. For the GPRA estimate for the Energy Star program, the Beta1 coefficient was reduced to 0.0082, implying a discount rate of about $43 \%$. This change resulted in an increase in the market shares of the (assumed) Energy Star products of roughly 11 percentage points. The specific results are shown in Table D.21.

Gas Water Heaters. The key NEMS inputs used by EIA for the AEO 2000 are shown in Table D.22. With these assumed costs, the model projects a zero share for the (near) condensing units that have efficiencies greater than 0.8.

The Energy Star program was assumed to target high-efficiency gas water heaters whose efficiencies are 0.6 or higher. As shown in Table D.20, two such units are shown, with efficiencies of 0.6 and 0.63. By 2005, the installed cost of the high-efficiency unit (at the 0.60 efficiency level) is assumed to fall from $\$ 400$ to $\$ 375$.

The logit parameters in the NEMS model related to the choice of gas water heaters are -0.05393 (Beta1) and -0.1136 (Beta2), implying a discount rate of about 47\%. For the GPRA estimate for the Energy Star program, the Beta1 coefficient was reduced to 0.0323, implying a discount rate of about $28 \%$. This change resulted in an increase in the market shares of the (assumed) Energy Star products of a little more than 12 percentage points. The specific results are shown in Table D.23. 


\section{Energy Star Room Air Conditioners}

For the year 2005, EIA assumes that efficiencies of room air conditioners will range from a low of 2.83 SEER (seasonal energy efficiency ratio) to a high of 3.52 SEER. In the AEO 2000 input file for the residential NEMS module, two models were at the low end of this range (SEER $=2.83$, SEER = 2.93), while two models were at the high end of the range. To achieve a more realistic set of choices, a model with an intermediate efficiency of 3.11 was added and the unit at the 2.93 (SEER) level was dropped. The increase in cost to go from a SEER of 2.83 to 2.93 was assumed to be $\$ 30$. Table D.24 shows both the original NEMS input data and the revised data.

The high-efficiency units with an energy-efficiency ratio (EER) of $>3.4$ were assumed to fall under the Energy Star program. In the base case, the combined market share for the units with SEERs of 3.43 and 3.52 were less than 1\%. The split between the lowest efficiency unit (SEER $=2.83$ ) and the intermediate efficiency unit (SEER $=3.11$ ) was generally about $75 \% / 25 \%$ in favor of the lowest efficiency model.

The logit parameters in the NEMS model related to the choice of room air conditioners are -0.017 (Beta1) and -0.12 (Beta2), implying a discount rate of over 100\%. For the GPRA estimate for the Energy Star program, the Beta1 coefficient was reduced to 0.007, implying a discount rate of about 58\%. This change resulted in an increase in the market shares of the (assumed) Energy Star products of a little more than 12 percentage points. (In addition, the market share of the model with the intermediate efficiency of 3.11 increased from approximately $25 \%$ to $35 \%$, also contributing to estimated energy savings). Table D.25 shows the specific results for the highefficiency model.

\section{Energy Star Dishwashers}

The NEMS baseline (AEO 2000) data input for the year 2005 shows three dishwashers, with energy factors $0.46,0.59$, and 0.71. The associated costs of these units are shown in Table D.26. Given the cost structure and logit choice parameters, the model suggests that consumers select slightly more than $6 \%$ of dishwashers with the 0.59 energy factor and virtually none of the very high efficiency units.

The logit parameters in the NEMS model related to the choice of dishwashers are -0.02738 (Beta1) and -0.02413 (Beta2), implying a discount rate of over 100\%. For the GPRA estimate for the Energy Star program, the Beta1 coefficient was reduced to 0.01338, implying a discount rate of about 55\%. This change resulted in an increase in the market share of the intermediate efficiency unit (energy factor $=0.59$ ) of about 15 percentage points (to over 20\%). The market share of the very high efficiency unit increases to a little more than $3 \%$. The specific results for the two high-efficiency models are shown in Table D.27.

\section{NEMS Modeling of Emerging Technologies}

NEMS was used to estimate the energy savings associated with the products being developed under BTS's Emerging Technologies program. The NEMS residential model used was modified to represent two technologies under this program: 1) heat pump water heater and 2) condensing gas water heater. The high-efficiency rooftop air conditioner program was modeled in the NEMS commercial model. 
The modifications to the NEMS input files (RTEKTY.txt for residential, KTECH.wk1 for commercial) for each type of equipment in the Emerging Technologies program are described below. The baseline assumptions made by EIA, the cost and performance attributes of the BTSsponsored technologies, and the resulting market shares for these most energy-efficient products are documented. For a few appliances, some changes were made in EIA's baseline assumptions; the reasons for these changes are briefly discussed.

\section{General Methodology}

For the FY 2002 GPRA effort, the water heater technologies funded by the Emerging Technologies program were modeled only in the residential model. The residential model uses a logit specification to estimate the market shares of specific technologies for a given type of appliance. For each appliance, two parameters generally influence how consumers trade off the initial purchase cost versus the annual operating cost of the appliance. The annual operating cost of course depends on the energy efficiency of each technology (or "model") and the price of energy.

\section{Data Input Modifications for Specific Appliance and Emerging Technology Programs}

The modifications to the NEMS input file (RTEKTY) for each appliance being developed under the Appliance and Emerging Technologies program are described below. The baseline assumptions made by EIA, the performance and cost assumptions for the BTS-sponsored technologies, and the resulting changes in the market shares for the most energy-efficient products are documented. For a few appliances, some changes were made in EIA's baseline assumptions; the reasons for these changes are briefly discussed.

Heat Pump Water Heater. The input file used for the AEO 2000 includes several categories of heat pump water heaters, two of which are shown in Table D.28. Inexplicably, the lower-cost unit is assumed to have a higher efficiency. With the discount rates used in the AEO 2000 for electric water heaters, only a very small number of the $\$ 1,000$ unit are predicted to be sold (and none of the higher-cost unit). A more moderately priced heat pump unit is assumed to become available in 2005 , with a cost of $\$ 900$ and an energy factor of 2.0. By 2015, the cost falls to $\$ 800$ and the energy factor increases to 2.2 .

The original $A E O 2000$ input file does not reflect the pending water heater standards that are scheduled to take effect in 2004 . Two modifications were made to crudely account for these standards: 1) technology 1 was assumed to be unavailable after 2003, and 2) the efficiency for technology 2 was changed to 0.89 with an unchanged cost. The new standard calls for a 50-gallon unit (as assumed in the table) to have an energy factor between 0.89 and 0.90 . These modifications are shown at the top of Table D.28.

The Appliance and Emerging Technologies program is assumed to lead to a more rapid commercialization of a moderately priced heat pump water heater, first available in 2004. But the principal impact of the program is to achieve a lower cost than the unit assumed to be introduced in 2005 in the AEO base case. As shown in Table D.28, the units are assumed initially to have energy efficiency rating of 2.0 and a cost of $\$ 700$ (installed). By 2010, further development will yield a unit with slightly higher efficiency (2.10) at a lower cost (\$650). By 2015 , further improvements lead to an efficiency of 2.2 at a cost of $\$ 600$. (Note that the $A E O$ 2000 input assumptions already include a heat pump water heater but at a substantially higher cost). (For modeling, the units introduced in the Emerging Technologies program replace the 
$\$ 900$ and $\$ 800$ units that are part of the AEO base case, and therefore the base case units are not shown in Table D.28).

One issue related to assessing benefits of this technology with the NEMS model is the appropriate discount rate to use. The logit parameters in the NEMS model related to the choice of electric water heaters are -0.01619 (Beta1) and -0.01952 (Beta2), implying a discount rate of about $83 \%$. At this discount rate, the high initial cost of the heat pump water heater, even with its much higher efficiency, discourages most consumers from choosing this technology. The NEMS results shown in Column 2 of Table D.29 show that the market share does not quite reach $5 \%$, even with the third-generation unit assumed in the analysis. (Note: The market shares in this discussion pertain only to electric water heaters.)

A more realistic overall assessment of the program is obtained by assuming that the ongoing Energy Star program for water heaters provides impetus for increased market acceptance of the heat pump water heater. In this scenario, the changes in the discount rates assumed for Energy Star program are combined with the introduction of the (lower-cost) heat pump water heater. As for the GPRA estimate for the Energy Star program, the Beta1 coefficient in the NEMS model was reduced to 0.0072 , implying a discount rate of about $37 \%$. As shown in Table D.29, the lower discount rates generate much higher penetrations of the heat pump water heater, ultimately reaching nearly $25 \%$ of sales by 2010 . (While Table D.29 displays the shares for only new homes, the shares for the replacement market are similar).

The program's energy savings (not shown here) are thus calculated as the difference between NEMS model runs that 1) include the heat pump waters assumed in the AEO base case and 2) substitute the lower-cost units assumed to stem from the Emerging Technologies program. In both runs, the adjustments to the discount rate (via the Beta1 coefficient) are the same as those used in evaluating the Energy Star program for water heaters. The Energy Star program is assumed to promote greater adoption of both conventional resistance units with energy factors of 0.95 or higher as well as heat pump water heaters. In essence, the program's savings are calculated as the difference between an Energy Star program with and without the units developed under the Emerging Technologies program. (The program summary contains further discussion of the savings from the Energy Star program without these lower-cost heat pumps.) Under Energy Star the market share of the $\$ 900$ heat pump unit in 2010 is 0.046 compared with a 0.239 share of the $\$ 700$ unit, as shown in Table D.29.)

Finally, the assumption of an ongoing Energy Star program raises the question of whether that program should receive some of the credit for energy savings brought about by this technology. No clear methodology exists for decomposing the benefits between applied R\&D program and market conditioning activities. Clearly, without the existence of the more efficient technology, Energy Star is limited in the impact that it can make toward reducing actual energy use. If such an attribution must be made for the GPRA process, 70\% of the savings are proposed to be assigned to the Emerging Technologies program and 30\% to Energy Star.

Condensing Gas Water Heater. The original AEO 2000 input file does not reflect the pending water heater standards that are scheduled to take effect in 2004. To account for these standards in the gas water heater market, the technologies with energy factors $<0.60$ (0.54 and 0.58) were specified to be unavailable after 2003. These modifications are shown in the top two lines of Table D.30. 
EIA includes a high-efficiency condensing gas water heater in its menu of technology choices for the $A E O 2000$. As Table D.30 shows, these units have very high costs. Not surprisingly, the model yields negligible market shares for this technology.

The Emerging Technologies program is assumed to lead to the commercialization of a moderately priced condensing gas water heater, first available in 2003. As Table D.30 shows, the units are assumed initially to have an energy efficiency rating of 0.8 and cost $\$ 550$ (installed). By 2010 , further development is assumed to yield a unit with slightly lower cost $(\$ 525)$.

As with the heat pump water heater, an issue related to the assessment of benefits with the NEMS model is the appropriate discount rate to employ. The logit parameters in the NEMS model related to the choice of gas water heaters are -0.05393 (Beta1) and -0.1136 (Beta2), implying a discount rate of about $47 \%$. At this discount rate, the higher initial cost of the BTSsponsored condensing gas water heater, even with its much higher efficiency, discourages most consumers from choosing this technology. The NEMS results shown in Column 2 of Table D.31 show that the market share only reaches about 1\%, even with the lower-cost second-generation unit assumed in the analysis.

As with the heat pump water heater, a more realistic overall assessment of the program is obtained by assuming that the ongoing Energy Star program for water heaters provides impetus for increased market acceptance of the condensing gas water heater. In this scenario, the changes in the discount rates assumed for Energy Star program are combined with the introduction of the (lower-cost) condensing gas water heater. As for the GPRA estimate for the Energy Star program, the Beta1 coefficient in the NEMS model was reduced to -0.03593, implying a discount rate of about $32 \%$. As shown in Table D.31, the lower discount rates generate much higher penetrations of the condensing water heater, ultimately reaching nearly $10 \%$ of sales by 2010 . The inputs in the AEO 2001 assume the introduction of a high efficiency noncondensing unit in 2015. This assumption is the principal explanation for why the share of the condensing unit drops between 2010 and 2020. (While Table D.31 displays the shares for only new homes, the shares for the replacement market are similar).

Again, the assumption of an ongoing Energy Star program raises the question of whether that program should receive some of the credit for energy savings brought about by this technology. No clear methodology exists for separating the benefits between applied R\&D program and market conditioning activities. Without the more efficient technology, Energy Star is limited in the impact it can make toward reducing actual energy use. If such an attribution must be made for the GPRA process, 70\% of the savings again is proposed to be assigned to the Emerging Technologies program and 30\% to Energy Star.

High-Efficiency Rooftop Air Conditioner. The rooftop air conditioner program uses competitive procurements of large numbers of units to stimulate the production of high-efficiency equipment. Its immediate goal is to get high-efficiency equipment installed in buildings owned by the federal government other state and local agencies. In the long term, however, a key outcome of the program is to provide incentives for manufacturers to reduce the cost of this equipment to all potential and private sector buyers.

With this long-term goal in mind, the assumed costs of high efficiency roof top air conditioners were adjusted in the NEMS commercial model to reflect the principal influence of this program. In NEMS, two air conditioners were specified in the rooftop category-a baseline unit $($ EER $=8.5)$

Appendix D - 11 
and a high-efficiency unit $(\mathrm{EER}=11.6)$. No subgroups were distinguished by capacity (e.g., 65 to $135 \mathrm{kBtu} / \mathrm{h}$ vs. 135 to $240 \mathrm{kBtu} / \mathrm{h})$.

An alternative technology spreadsheet was developed to model the rooftop initiative in the Emerging Technologies. (In most recent version of NEMS, the technology cost and performance inputs are in a spreadsheet). In this spreadsheet, the user can adjust the incremental cost between baseline unit and the high-efficiency unit.

For the GPRA analysis, the incremental cost was reduced by $40 \%$. Given the proportion of the market assumed in the NEMS to display high discount rates in the selection of equipment, this cost reduction was necessary to yield a $9 \%$ penetration of the high-efficiency unit in 2005 . The penetration rate falls to $6 \%$ in 2010 possibly the result of a couple of factors: 1) greater efficiency of the baseline unit or 2) lower energy costs. As this point, the exact reasons for this behavior have not yet been investigated. By 2020, the proportion of the total stock using the highefficiency unit is about $5 \%$.

\section{GPRA Envelope Calculations Using NEMS}

The general approach for GPRA envelope calculations using NEMS was to simulate the effect of an envelope technology using the Facility Energy Decision System (FEDS) ${ }^{1}$ model for many different building types, sizes, vintages, and locations. The heating and cooling loads were calculated for each building with and without the envelope technology being evaluated. The changes in the heating and cooling loads were then used to modify the heating and cooling envelope factors used in NEMS. These factors were input as a vector for each building type and census region; these vectors captured both the thermal impact and the expected market penetration by year. Market penetration estimates were based on input from the DOE Program Manager or their representatives.

\section{FEDS Modeling}

To estimate the national impact of introducing a new envelope technology, the impact of that technology must be accurately captured within the buildings where it is likely to be employed. For each technology, the impact was simulated in 3,960 commercial buildings and 1,188 residential buildings representing all combinations of building type, size, vintage, and location (see Table D.32).

\section{Aggregating FEDS Results for NEMS}

Because NEMS only models one of each building type in each of the nine census regions, the FEDS results needed to be aggregated for input into NEMS.

City Weights. The cities shown in Table D.32 were selected for the FEDS analysis because the weather is characteristic of the climate in the different portions of the census regions. Because NEMS operates on a census region bases, weighted averages of the FEDS results for individual weather cities were produced to represent the loads within a census region. Table D.33 shows the weights given to each city for each census region.

\footnotetext{
1 Pacific Northwest National Laboratory (1998).
} 
Floor Area Weights. The fraction of floor space within each size category for each commercial building type was determined using data from Commercial Buildings Energy Consumption Survey (CBECS) ${ }^{2}$ and is shown in Table D.34.

Table D.35 shows the fraction of floor space within each size category for each residential building type (single family, mobile homes, and multifamily). The data for single-family and mobile homes was determined using data from Residential Energy Consumption Survey $(\mathrm{RECS}){ }^{3},{ }^{4}$ and the data for multifamily homes was determined using data from RECS and apartment stock data from the National Multi-Housing Council. ${ }^{5}$

Vintage Weights. All vintages were given equal weighting.

Market Penetration. The DOE program manager, or representative, provided market penetration point estimates. For example, the Program Manager estimated the market penetration to be $15 \%$ in 2020 for quick-fill walls in new single-story buildings. Given that $41.8 \%{ }^{6}$ of commercial buildings are single story, this resulted in a market penetration rate of $6.3 \%$

These estimates were then used in the previously developed and documented market penetration model (see Appendix C) to estimate the market penetration by year. Pertinent data for the market penetration estimates are provided in Table D.36.

\section{Baseline Assumptions}

Consistent with the NEMS model, the heating and cooling envelope factors were assumed to be decreasing over time. These changes account for technological improvements over time that would occur without the DOE program. The baseline envelope factors in NEMS are modified annually to account for the technological improvements, and the modifiers are calculated using the following equation with 1995 being the base year:

$$
\text { Baseline Modifier } r_{\text {new buildings }}=0.94^{\left(\frac{\text { CurrentYear-1995 }}{25}\right)}
$$

and

$$
\text { Baseline Modifier }{ }_{\text {existing buildings }}=0.96^{\left(\frac{\text { CurrentYear-1995 }}{25}\right)}
$$

The program benefits are in addition to the baseline modifier.

\footnotetext{
21995 CBECS, Table 9. Where no data were available, expert judgment was used.

31997 RECS, Table HC1-4b, single-family.

41997 RECS, Table HC1-4b, five or more units.

5 http://www.nmhc.org/research/default.html.

61995 CBECS, Table 9.
} 


\section{Special Considerations}

For the electrochromic windows program, 30\% of the lighting energy used in commercial buildings is also assumed to be saved. These savings occur at the same rate as the penetration of the electrochromic technology.

\section{Output}

The output for each technology has nine columns of output containing the following information.

- census division

- building type

- year

- total heating envelope factor adjustment for new buildings

- total cooling envelope factor adjustment for new buildings

- total heating envelope factor adjustment for existing buildings

- total cooling envelope factor adjustment for existing buildings

- lighting load adjustment for new buildings

- lighting load adjustment for existing buildings.

\section{References}

Arthur D. Little, Inc (ADL). 1998. "EIA Technology Forecast Updates-Residential and Commercial Building Technologies, Reference Case."

"Commercial Buildings Energy Consumption Survey." 1995. U.S. Department of Energy, Energy Information Administration. eia.doc.gov/emeu/cbecs/contents.html

Decision Analysis Corporation. 1996. Lighting System Technology Characterization for the NEMS Commercial Sector Demand Module. Final Report, Subtask 2-1-b.

Energy Information Administration. 2000. Annual Energy Outlook. U.S. Department of Energy. Energy Information Administration. 2001. Annual Energy Outlook. U.S. Department of Energy.

Pacific Northwest National Laboratory. 1998. Facility Energy Decision System User's Guide, Release 4.0. PNNL-10542, Rev 2.

"Residential Energy Consumption Survey." 1997. U.S. Department of Energy, Energy Information Administration. eia.doc.gov/emeu/recs/contents.html

Vineyard, E.A. and J.R. Sand. 1998. "Fridge of the Future: Designing a One Kilowatt-Hour/Day Domestic Refrigerator Freezer." In 1998 ACEEE Summer Study Proceedings.

\section{List of Terms}

ADL Arthur D. Little

AEO Annual Energy Outlook (report)

AFUE annual fuel utilization efficiency 


\begin{tabular}{ll}
\hline \hline & \\
BTS & Office of Building Technology, State and Community Programs \\
CBECS & Commercial Buildings Energy Consumption Survey \\
COP & coefficient of performance \\
DOE & U.S. Department of Energy \\
EER & energy efficiency ratio \\
EIA & Energy Information Administration \\
FEDS & Facility Energy Decision System \\
GPRA & Government Performance and Results Act of 1993 \\
LBNL & Lawrence Berkeley National Laboratory \\
NEMS & National Energy Modeling System \\
ORNL & Oak Ridge National Laboratory \\
RECS & Residential Energy Consumption Survey \\
SEER & seasonal energy efficiency ratio
\end{tabular}


Table D.1. Size of the Residential Building Market

\begin{tabular}{|l|l|l|c|c|c|c|c|c|}
\hline Building Type & \multirow{2}{*}{ Vintage } & \multirow{2}{*}{ Region } & \multicolumn{6}{|c|}{ Millions of Households } \\
\cline { 4 - 9 } & & & $\mathbf{2 0 0 1}$ & $\mathbf{2 0 0 5}$ & $\mathbf{2 0 1 0}$ & $\mathbf{2 0 1 5}$ & $\mathbf{2 0 2 0}$ & $\mathbf{2 0 3 0}$ \\
\hline Single Family & New & North & .52 & .52 & .53 & .52 & .51 & .50 \\
\hline Single Family & New & South & .52 & .52 & .53 & .52 & .51 & .50 \\
\hline Mobile Homes & New & North & .14 & .14 & .13 & .12 & .1 & .09 \\
\hline Mobile Homes & New & South & .17 & .17 & .16 & .15 & .13 & .11 \\
\hline Multifamily & New & North & .18 & .18 & .22 & .22 & .19 & .18 \\
\hline Multifamily & New & South & .18 & .18 & .22 & .22 & .19 & .18 \\
\hline Residential & New & All & 1.71 & 1.71 & 1.79 & 1.75 & 1.63 & 1.56 \\
\hline Residential & New & Cumulative & 1.71 & 8.56 & 17.52 & 26.28 & 34.49 & 49.99 \\
\hline
\end{tabular}

Table D.2. Potential Penetration Rates for New Construction

\begin{tabular}{|c|c|c|c|c|c|c|c|c|}
\hline \multirow[t]{2}{*}{ Building Type } & \multirow[t]{2}{*}{ Vintage } & \multirow[t]{2}{*}{ Region } & \multicolumn{6}{|c|}{$\%$ of New Construction in Period } \\
\hline & & & 2001 & 2005 & 2010 & 2015 & 2020 & 2030 \\
\hline Single Family & New & North & .3 & 3.1 & 11.6 & 22.1 & 27 & 28.6 \\
\hline Single Family & New & South & .3 & 3.1 & 11.6 & 22.1 & 27 & 28.6 \\
\hline Mobile Homes & New & North & .1 & 1 & 3.8 & 7.3 & 8.9 & 9.4 \\
\hline Mobile Homes & New & South & .1 & 1 & 3.8 & 7.3 & 8.9 & 9.4 \\
\hline Multifamily & New & North & .1 & .7 & 2.6 & 4.9 & 5.9 & 6.3 \\
\hline Multifamily & New & South & .1 & .7 & 2.6 & 4.9 & 5.9 & 6.3 \\
\hline
\end{tabular}

Table D.3. Number of Units Impacted by the BTS

\begin{tabular}{|c|c|c|c|c|c|c|c|c|}
\hline \multirow[t]{2}{*}{ Building Type } & \multirow[t]{2}{*}{ Vintage } & \multirow[t]{2}{*}{ Region } & \multicolumn{6}{|c|}{ Millions of Households } \\
\hline & & & 2001 & 2005 & 2010 & 2015 & 2020 & 2030 \\
\hline Single Family & New & North & .002 & .016 & .061 & .115 & .138 & .143 \\
\hline Single Family & New & South & .002 & .016 & .061 & .115 & .138 & .143 \\
\hline Mobile Homes & New & North & .0001 & .001 & .005 & .009 & .009 & .008 \\
\hline Mobile Homes & New & South & .0002 & .002 & .006 & .01 & .012 & .010 \\
\hline Multifamily & $\mathrm{New}$ & North & .0002 & .001 & .006 & .011 & .011 & .011 \\
\hline Multifamily & New & South & .0002 & .001 & .006 & .011 & .011 & .011 \\
\hline
\end{tabular}

Table D.4. Cumulative Impacted of Household Units

\begin{tabular}{|l|l|l|c|c|c|c|c|c|}
\hline Building Type & \multirow{2}{*}{ Vintage } & \multicolumn{7}{|c|}{ Millions of Households } \\
\cline { 3 - 9 } & & Region & $\mathbf{2 0 0 1}$ & $\mathbf{2 0 0 5}$ & $\mathbf{2 0 1 0}$ & $\mathbf{2 0 1 5}$ & $\mathbf{2 0 2 0}$ & $\mathbf{2 0 3 0}$ \\
\hline Single Family & New & North & .002 & .040 & .245 & .720 & 1.67 & 2.78 \\
\hline Single Family & New & South & .002 & .040 & .245 & .720 & 1.67 & 2.78 \\
\hline Mobile Homes & New & North & .0001 & .004 & .020 & .056 & .100 & .183 \\
\hline Mobile Homes & New & South & .0002 & .004 & .025 & .069 & .122 & .224 \\
\hline Multifamily & New & North & .0002 & .003 & .022 & .066 & .120 & .230 \\
\hline Multifamily & New & South & .0002 & .003 & .022 & .066 & .120 & .230 \\
\hline
\end{tabular}




\section{D.5. End-Use Loads for Heating, Cooling, and Water Heating for New Residential Buildings (MBtu/household/yr)}

\begin{tabular}{|c|c|c|c|c|c|c|c|c|}
\hline Building Type & Vintage & Region & 2001 & 2005 & 2010 & 2015 & 2020 & 2030 \\
\hline \multicolumn{9}{|c|}{ End Use: Space Heating } \\
\hline Single Family & New & North & 42.24 & 42.24 & 42.24 & 42.24 & 42.24 & 42.24 \\
\hline Single Family & New & South & 12.98 & 12.98 & 12.98 & 12.98 & 12.98 & 12.98 \\
\hline Mobile Homes & New & North & 42.24 & 42.24 & 42.24 & 42.24 & 42.24 & 42.24 \\
\hline Mobile Homes & New & South & 12.98 & 12.98 & 12.98 & 12.98 & 12.98 & 12.98 \\
\hline Multifamily & New & North & 42.24 & 42.24 & 42.24 & 42.24 & 42.24 & 42.24 \\
\hline Multifamily & New & South & 12.98 & 12.98 & 12.98 & 12.98 & 12.98 & 12.98 \\
\hline \multicolumn{9}{|c|}{ End Use: Space Cooling } \\
\hline Single Family & New & North & 8.62 & 8.62 & 8.62 & 8.62 & 8.62 & 8.62 \\
\hline Single Family & New & South & 13.58 & 13.58 & 13.58 & 13.58 & 13.58 & 13.58 \\
\hline Mobile Homes & New & North & 8.62 & 8.62 & 8.62 & 8.62 & 8.62 & 8.62 \\
\hline Mobile Homes & New & South & 13.58 & 13.58 & 13.58 & 13.58 & 13.58 & 13.58 \\
\hline Multifamily & New & North & 8.62 & 8.62 & 8.62 & 8.62 & 8.62 & 8.62 \\
\hline Multifamily & New & South & 13.58 & 13.58 & 13.58 & 13.58 & 13.58 & 13.58 \\
\hline \multicolumn{9}{|c|}{ End Use: Water Heating } \\
\hline Single Family & New & North & 12.94 & 12.94 & 12.94 & 12.94 & 12.94 & 12.94 \\
\hline Single Family & New & South & 12.94 & 12.94 & 12.94 & 12.94 & 12.94 & 12.94 \\
\hline Mobile Homes & New & North & 12.94 & 12.94 & 12.94 & 12.94 & 12.94 & 12.94 \\
\hline Mobile Homes & New & South & 12.94 & 12.94 & 12.94 & 12.94 & 12.94 & 12.94 \\
\hline Multifamily & New & North & 12.94 & 12.94 & 12.94 & 12.94 & 12.94 & 12.94 \\
\hline Multifamily & New & South & 12.94 & 12.94 & 12.94 & 12.94 & 12.94 & 12.94 \\
\hline
\end{tabular}

Table D.6. Percent Load Reductions for the Residential Building R\&D Program for Space Heating and Cooling and Water Heating

\begin{tabular}{|c|c|c|c|c|c|c|c|c|}
\hline \multirow[t]{2}{*}{ Building Type } & \multirow[t]{2}{*}{ Vintage } & \multirow[t]{2}{*}{ Region } & \multicolumn{6}{|c|}{$\%$ Load Reduction } \\
\hline & & & 2001 & 2005 & 2010 & 2015 & 2020 & 2030 \\
\hline Single Family & $\mathrm{New}$ & North & 38 & 50 & 50 & 50 & 50 & 50 \\
\hline Single Family & New & South & 38 & 50 & 50 & 50 & 50 & 50 \\
\hline Mobile Homes & New & North & 38 & 50 & 50 & 50 & 50 & 50 \\
\hline Mobile Homes & New & South & 38 & 50 & 50 & 50 & 50 & 50 \\
\hline Multifamily & New & North & 38 & 50 & 50 & 50 & 50 & 50 \\
\hline Multifamily & New & South & 38 & 50 & 50 & 50 & 50 & 50 \\
\hline
\end{tabular}


Table D.7. Building-Level Load Reductions by End Use (MMBtu/household/yr)

\begin{tabular}{|l|l|l|l|l|l|l|l|l|l|}
\hline Building Type & Vintage & Region & $\mathbf{2 0 0 1}$ & $\mathbf{2 0 0 5}$ & $\mathbf{2 0 1 0}$ & $\mathbf{2 0 1 5}$ & $\mathbf{2 0 2 0}$ & $\mathbf{2 0 3 0}$ \\
\hline End Use: Space Heating \\
\hline Single Family & New & North & 16.05 & 21.12 & 21.12 & 21.12 & 21.12 & 21.12 \\
\hline Single Family & New & South & 4.93 & 2.465 & 2.465 & 2.465 & 2.465 & 2.465 \\
\hline Mobile Homes & New & North & 16.05 & 21.12 & 21.12 & 21.12 & 21.12 & 21.12 \\
\hline Mobile Homes & New & South & 4.93 & 2.465 & 2.465 & 2.465 & 2.465 & 2.465 \\
\hline Multifamily & New & North & 16.05 & 21.12 & 21.12 & 21.12 & 21.12 & 21.12 \\
\hline Multifamily & New & South & 4.93 & 2.465 & 2.465 & 2.465 & 2.465 & 2.465 \\
\hline End Use: Space Cooling \\
\hline \multicolumn{7}{|l|l|l|l|}{} \\
\hline Single Family & New & North & 3.27 & 4.31 & 4.31 & 4.31 & 4.31 & 4.31 \\
\hline Single Family & New & South & 5.16 & 6.79 & 6.79 & 6.79 & 6.79 & 6.79 \\
\hline Mobile Homes & New & North & 3.27 & 4.31 & 4.31 & 4.31 & 4.31 & 4.31 \\
\hline Mobile Homes & New & South & 5.16 & 6.79 & 6.79 & 6.79 & 6.79 & 6.79 \\
\hline Multifamily & New & North & 3.27 & 4.31 & 4.31 & 4.31 & 4.31 & 4.31 \\
\hline Multifamily & New & South & 5.16 & 6.79 & 6.79 & 6.79 & 6.79 & 6.79 \\
\hline End Use: Water Heating & \multicolumn{7}{|l|}{} \\
\hline Single Family & New & North & 4.92 & 6.47 & 6.47 & 6.47 & 6.47 & 6.47 \\
\hline Single Family & New & South & 4.92 & 6.47 & 6.47 & 6.47 & 6.47 & 6.47 \\
\hline Mobile Homes & New & North & 4.92 & 6.47 & 6.47 & 6.47 & 6.47 & 6.47 \\
\hline Mobile Homes & New & South & 4.92 & 6.47 & 6.47 & 6.47 & 6.47 & 6.47 \\
\hline Multifamily & New & North & 4.92 & 6.47 & 6.47 & 6.47 & 6.47 & 6.47 \\
\hline Multifamily & New & South & 4.92 & 6.47 & 6.47 & 6.47 & 6.47 & 6.47 \\
\hline
\end{tabular}

Table D.8. Regional Load Reductions by End Use (TBtu/yr)

\begin{tabular}{|l|l|l|c|c|c|c|c|c|c|}
\hline Building Type & Vintage & Region & $\mathbf{2 0 0 1}$ & $\mathbf{2 0 0 5}$ & $\mathbf{2 0 1 0}$ & $\mathbf{2 0 1 5}$ & $\mathbf{2 0 2 0}$ & $\mathbf{2 0 3 0}$ \\
\hline End Use: Space Heating \\
\hline Single Family & New & North & .03 & .84 & 5.17 & 15.21 & 35.27 & 58.71 \\
\hline Single Family & New & South & .01 & .10 & .60 & 1.77 & 4.11 & 6.85 \\
\hline Mobile Homes & New & North & .002 & .08 & .42 & 1.18 & 2.11 & 3.86 \\
\hline Mobile Homes & New & South & .001 & .01 & .06 & .17 & .30 & .55 \\
\hline Multifamily & New & North & .003 & .06 & .46 & 1.39 & 2.53 & 4.86 \\
\hline Multifamily & New & South & .001 & .007 & .05 & .16 & .30 & .57 \\
\hline End Use: Space Cooling & \multicolumn{7}{|l|}{} \\
\hline Single Family & New & North & .01 & .17 & 1.06 & 3.10 & 7.20 & 11.98 \\
\hline Single Family & New & South & .01 & .27 & 1.66 & 4.89 & 11.34 & 18.88 \\
\hline Mobile Homes & New & North & .0003 & .02 & .09 & .24 & .43 & .79 \\
\hline Mobile Homes & New & South & .001 & .03 & .17 & .47 & .83 & 1.52 \\
\hline Multifamily & New & North & .0007 & .01 & .09 & .28 & .52 & .99 \\
\hline Multifamily & New & South & .001 & .02 & .15 & .45 & .81 & 1.56 \\
\hline End Use: Water Heating & \multicolumn{7}{|l|}{} \\
\hline Single Family & New & North & .01 & .26 & 1.59 & 4.66 & 10.8 & 17.99 \\
\hline Single Family & New & South & .01 & .26 & 1.59 & 4.66 & 10.8 & 17.99 \\
\hline Mobile Homes & New & North & .001 & .03 & .13 & .36 & .65 & 1.18 \\
\hline Mobile Homes & New & South & .001 & .03 & .16 & .45 & .79 & 1.15 \\
\hline Multifamily & New & North & .001 & .02 & .14 & .43 & .78 & 1.49 \\
\hline Multifamily & New & South & .001 & .02 & .14 & .43 & .78 & 1.49 \\
\hline
\end{tabular}


Table D.9. Cumulative Regional Load Reductions (TBtu/yr)

\begin{tabular}{|c|c|c|c|c|c|c|c|c|}
\hline $\begin{array}{c}\text { Building } \\
\text { Type }\end{array}$ & Vintage & Region & 2001 & 2005 & 2010 & 2015 & 2020 & 2030 \\
\hline \multicolumn{9}{|c|}{ End Use: Space Heating } \\
\hline Single Family & New & North & 0.025 & 0.798 & 5.127 & 15.154 & 28.822 & 58.601 \\
\hline Single Family & New & South & 0.010 & 0.319 & 2.051 & 6.063 & 11.532 & 23.446 \\
\hline Mobile Homes & New & North & 0.002 & 0.070 & 0.423 & 1.181 & 2.107 & 3.871 \\
\hline Mobile Homes & New & South & 0.001 & 0.034 & 0.207 & 0.577 & 1.030 & 1.893 \\
\hline Multifamily & New & North & 0.003 & 0.066 & 0.459 & 1.393 & 2.540 & 4.839 \\
\hline Multifamily & New & South & 0.001 & 0.026 & 0.184 & 0.557 & 1.016 & 1.936 \\
\hline \multicolumn{9}{|c|}{ End Use: Space Cooling } \\
\hline Single Family & New & North & 0.005 & 0.163 & 1.046 & 3.093 & 5.882 & 11.959 \\
\hline Single Family & New & South & 0.008 & 0.257 & 1.648 & 4.872 & 9.266 & 18.840 \\
\hline Mobile Homes & New & North & 0.000 & 0.014 & 0.086 & 0.241 & 0.430 & 0.790 \\
\hline Mobile Homes & New & South & 0.001 & 0.028 & 0.166 & 0.464 & 0.828 & 1.521 \\
\hline Multifamily & New & North & 0.001 & 0.013 & 0.094 & 0.284 & 0.518 & 0.987 \\
\hline Multifamily & New & South & 0.001 & 0.021 & 0.148 & 0.448 & 0.817 & 1.556 \\
\hline \multicolumn{9}{|c|}{ End Use: Water Heating } \\
\hline Single Family & New & North & 0.008 & 0.245 & 1.571 & 4.642 & 8.830 & 17.952 \\
\hline Single Family & New & South & 0.008 & 0.245 & 1.571 & 4.642 & 8.830 & 17.952 \\
\hline Mobile Homes & New & North & 0.001 & 0.022 & 0.130 & 0.362 & 0.646 & 1.186 \\
\hline Mobile Homes & New & South & 0.001 & 0.026 & 0.158 & 0.442 & 0.789 & 1.449 \\
\hline Multifamily & New & North & 0.001 & 0.020 & 0.141 & 0.427 & 0.778 & 1.482 \\
\hline Multifamily & New & South & 0.001 & 0.020 & 0.141 & 0.427 & 0.778 & 1.482 \\
\hline
\end{tabular}

Table D.10 Existing Equipment Efficiencies

\begin{tabular}{|l|l|l|l|c|c|c|c|c|c|}
\hline End Use & $\begin{array}{l}\text { Fuel } \\
\text { Type }\end{array}$ & \multicolumn{1}{|c|}{$\begin{array}{c}\text { Equipment } \\
\text { Type }\end{array}$} & Units* & $\mathbf{2 0 0 1}$ & $\mathbf{2 0 0 5}$ & $\mathbf{2 0 1 0}$ & $\mathbf{2 0 1 5}$ & $\mathbf{2 0 2 0}$ & $\mathbf{2 0 3 0}$ \\
\hline Space Heat & Elec & Heat Pump & COP & 1.99 & 1.99 & 1.99 & 1.99 & 1.99 & 1.99 \\
\hline Space Heat & Elec & Forced Air & AFUE & 1 & 1 & 1 & 1 & 1 & 1 \\
\hline Space Heat & Gas & Furnace & AFUE & .78 & .78 & .78 & .78 & .78 & .78 \\
\hline Space Heat & Oil & Furnace & AFUE & .78 & .78 & .78 & .78 & .78 & .78 \\
\hline Space Heat & Gas & $\begin{array}{l}\text { High-Efficiency } \\
\text { Furnace }\end{array}$ & AFUE & .92 & .92 & .92 & .92 & .92 & .92 \\
\hline Space Heat & Gas & Heat Pump & COP & 1.4 & 1.4 & 1.4 & 1.4 & 1.4 & 1.4 \\
\hline Space Cool & Elec & Heat Pump & COP & 2.93 & 2.93 & 2.93 & 2.93 & 2.93 & 2.93 \\
\hline Space Cool & Elec & $\begin{array}{l}\text { Central Air } \\
\text { Conditioning }\end{array}$ & COP & 3.02 & 3.02 & 3.02 & 3.02 & 3.02 & 3.02 \\
\hline Space Cool & Elec & Room Air & COP & 2.64 & 2.64 & 2.64 & 2.64 & 2.64 & 2.64 \\
\hline Space Cool & Gas & Heat Pump & COP & .95 & .95 & .95 & .95 & .95 & .95 \\
\hline Water Heat & Elec & Storage & Effic & .89 & .93 & .93 & .93 & .93 & .93 \\
\hline Water Heat & Gas & Storage & Effic & .55 & .62 & .62 & .62 & .62 & .62 \\
\hline Water Heat & Oil & Storage & Effic & .55 & .55 & .56 & .56 & .56 & .56 \\
\hline${ }^{*}$ COP = coefficient of performance; AFUE $=$ annual fuel utilization efficiency; Effic = efficiency. \\
\hline
\end{tabular}


Table D.11. Potential Energy Savings (TBtu/yr)

\begin{tabular}{|c|c|c|c|c|c|c|c|}
\hline Building Type & Region & 2001 & 2005 & 2010 & 2015 & 2020 & 2030 \\
\hline \multicolumn{8}{|c|}{ Space Heating: Electric Heat Pump } \\
\hline Single Family & North & 0.013 & 0.401 & 2.576 & 7.615 & 14.484 & 29.448 \\
\hline Single Family & South & 0.005 & 0.161 & 1.031 & 3.047 & 5.795 & 11.782 \\
\hline Mobile Homes & North & 0.001 & 0.035 & 0.213 & 0.593 & 1.059 & 1.945 \\
\hline Mobile Homes & South & 0.001 & 0.017 & 0.104 & 0.290 & 0.518 & 0.951 \\
\hline Multifamily & North & 0.001 & 0.033 & 0.231 & 0.700 & 1.276 & 2.432 \\
\hline Multifamily & South & 0.001 & 0.013 & 0.092 & 0.280 & 0.511 & 0.973 \\
\hline \multicolumn{8}{|c|}{ Space Heating: Electric Forced Air } \\
\hline Single Family & North & 0.02 & 0.80 & 5.13 & 15.15 & 28.82 & 58.60 \\
\hline Single Family & South & 0.01 & 0.32 & 2.05 & 6.06 & 11.53 & 23.45 \\
\hline Mobile Homes & North & 0.00 & 0.07 & 0.42 & 1.18 & 2.11 & 3.87 \\
\hline Mobile Homes & South & 0.00 & 0.03 & 0.21 & 0.58 & 1.03 & 1.89 \\
\hline Multifamily & North & 0.00 & 0.07 & 0.46 & 1.39 & 2.54 & 4.84 \\
\hline Multifamily & South & 0.00 & 0.03 & 0.18 & 0.56 & 1.02 & 1.94 \\
\hline \multicolumn{8}{|c|}{ Space Heating: Gas Furnace } \\
\hline Single Family & North & 0.03 & 1.02 & 6.57 & 19.43 & 36.95 & 75.13 \\
\hline Single Family & South & 0.01 & 0.41 & 2.63 & 7.77 & 14.78 & 30.06 \\
\hline Mobile Homes & North & 0.00 & 0.09 & 0.54 & 1.51 & 2.70 & 4.96 \\
\hline Mobile Homes & South & 0.00 & 0.04 & 0.27 & 0.74 & 1.32 & 2.43 \\
\hline Multifamily & North & 0.00 & 0.08 & 0.59 & 1.79 & 3.26 & 6.20 \\
\hline Multifamily & South & 0.00 & 0.03 & 0.24 & 0.71 & 1.30 & 2.48 \\
\hline \multicolumn{8}{|c|}{ Space Heating: Oil Furnace } \\
\hline Single Family & North & 0.03 & 1.02 & 6.57 & 19.43 & 36.95 & 75.13 \\
\hline Single Family & South & 0.01 & 0.41 & 2.63 & 7.77 & 14.78 & 30.06 \\
\hline Mobile Homes & North & 0.00 & 0.09 & 0.54 & 1.51 & 2.70 & 4.96 \\
\hline Mobile Homes & South & 0.00 & 0.04 & 0.27 & 0.74 & 1.32 & 2.43 \\
\hline Multifamily & North & 0.00 & 0.08 & 0.59 & 1.79 & 3.26 & 6.20 \\
\hline Multifamily & South & 0.00 & 0.03 & 0.24 & 0.71 & 1.30 & 2.48 \\
\hline \multicolumn{8}{|c|}{ Space Heating: High-Efficiency Gas Furnace } \\
\hline Single Family & North & 0.03 & 0.87 & 5.57 & 16.47 & 31.33 & 63.70 \\
\hline Single Family & South & 0.01 & 0.35 & 2.23 & 6.59 & 12.53 & 25.48 \\
\hline Mobile Homes & North & 0.00 & 0.08 & 0.46 & 1.28 & 2.29 & 4.21 \\
\hline Mobile Homes & South & 0.00 & 0.04 & 0.22 & 0.63 & 1.12 & 2.06 \\
\hline Multifamily & North & 0.00 & 0.07 & 0.50 & 1.51 & 2.76 & 5.26 \\
\hline Multifamily & South & 0.00 & 0.03 & 0.20 & 0.61 & 1.10 & 2.10 \\
\hline \multicolumn{8}{|c|}{ Space Heating: Gas Heat Pump } \\
\hline Single Family & North & 0.02 & 0.57 & 3.66 & 10.82 & 20.59 & 41.86 \\
\hline Single Family & South & 0.01 & 0.23 & 1.47 & 4.33 & 8.24 & 16.75 \\
\hline Mobile Homes & North & 0.00 & 0.05 & 0.30 & 0.84 & 1.51 & 2.77 \\
\hline Mobile Homes & South & 0.00 & 0.02 & 0.15 & 0.41 & 0.74 & 1.35 \\
\hline Multifamily & North & 0.00 & 0.05 & 0.33 & 0.99 & 1.81 & 3.46 \\
\hline Multifamily & South & 0.00 & 0.02 & 0.13 & 0.40 & 0.73 & 1.38 \\
\hline \multicolumn{8}{|c|}{ Space Cooling: Heat Pump } \\
\hline Single Family & North & 0.00 & 0.06 & 0.36 & 1.06 & 2.01 & 4.08 \\
\hline Single Family & South & 0.00 & 0.09 & 0.56 & 1.66 & 3.16 & 6.43 \\
\hline Mobile Homes & North & 0.00 & 0.00 & 0.03 & 0.08 & 0.15 & 0.27 \\
\hline Mobile Homes & South & 0.00 & 0.01 & 0.06 & 0.16 & 0.28 & 0.52 \\
\hline Multifamily & North & 0.00 & 0.00 & 0.03 & 0.10 & 0.18 & 0.34 \\
\hline Multifamily & South & 0.00 & 0.01 & 0.05 & 0.15 & 0.28 & 0.53 \\
\hline \multicolumn{8}{|c|}{ Space Cooling: Central Air Conditioning } \\
\hline Single Family & North & 0.00 & 0.04 & 0.27 & 0.79 & 1.51 & 3.07 \\
\hline Single Family & South & 0.00 & 0.07 & 0.42 & 1.25 & 2.38 & 4.83 \\
\hline
\end{tabular}




\begin{tabular}{|c|c|c|c|c|c|c|c|}
\hline Building Type & Region & 2001 & 2005 & 2010 & 2015 & 2020 & 2030 \\
\hline Mobile Homes & North & 0.00 & 0.00 & 0.02 & 0.06 & 0.11 & 0.20 \\
\hline Mobile Homes & South & 0.00 & 0.01 & 0.04 & 0.12 & 0.21 & 0.39 \\
\hline Multifamily & North & 0.00 & 0.00 & 0.02 & 0.07 & 0.13 & 0.25 \\
\hline Multifamily & South & 0.00 & 0.01 & 0.04 & 0.11 & 0.21 & 0.40 \\
\hline \multicolumn{8}{|c|}{ Space Cooling: Room Air } \\
\hline Single Family & North & 0.00 & 0.06 & 0.40 & 1.17 & 2.23 & 4.53 \\
\hline Single Family & South & 0.00 & 0.10 & 0.62 & 1.85 & 3.51 & 7.14 \\
\hline Mobile Homes & North & 0.00 & 0.01 & 0.03 & 0.09 & 0.16 & 0.30 \\
\hline Mobile Homes & South & 0.00 & 0.01 & 0.06 & 0.18 & 0.31 & 0.58 \\
\hline Multifamily & North & 0.00 & 0.01 & 0.04 & 0.11 & 0.20 & 0.37 \\
\hline Multifamily & South & 0.00 & 0.01 & 0.06 & 0.17 & 0.31 & 0.59 \\
\hline \multicolumn{8}{|c|}{ Space Cooling: Gas Heat Pump } \\
\hline Single Family & North & 0.01 & 0.17 & 1.10 & 3.26 & 6.19 & 12.59 \\
\hline Single Family & South & 0.01 & 0.27 & 1.73 & 5.13 & 9.75 & 19.83 \\
\hline Mobile Homes & North & 0.00 & 0.02 & 0.09 & 0.25 & 0.45 & 0.83 \\
\hline Mobile Homes & South & 0.00 & 0.03 & 0.18 & 0.49 & 0.87 & 1.60 \\
\hline Multifamily & North & 0.00 & 0.01 & 0.10 & 0.30 & 0.55 & 1.04 \\
\hline Multifamily & South & 0.00 & 0.02 & 0.16 & 0.47 & 0.86 & 1.64 \\
\hline \multicolumn{8}{|c|}{ Water Heat: Electric } \\
\hline Single Family & North & 0.01 & 0.26 & 1.69 & 4.99 & 9.49 & 19.30 \\
\hline Single Family & South & 0.01 & 0.26 & 1.69 & 4.99 & 9.49 & 19.30 \\
\hline Mobile Homes & North & 0.00 & 0.02 & 0.14 & 0.39 & 0.69 & 1.28 \\
\hline Mobile Homes & South & 0.00 & 0.03 & 0.17 & 0.48 & 0.85 & 1.56 \\
\hline Multifamily & North & 0.00 & 0.02 & 0.15 & 0.46 & 0.84 & 1.59 \\
\hline Multifamily & South & 0.00 & 0.02 & 0.15 & 0.46 & 0.84 & 1.59 \\
\hline \multicolumn{8}{|c|}{ Water Heat: Gas } \\
\hline Single Family & North & 0.01 & 0.39 & 2.53 & 7.49 & 14.24 & 28.96 \\
\hline Single Family & South & 0.01 & 0.39 & 2.53 & 7.49 & 14.24 & 28.96 \\
\hline Mobile Homes & North & 0.00 & 0.03 & 0.21 & 0.58 & 1.04 & 1.91 \\
\hline Mobile Homes & South & 0.00 & 0.04 & 0.26 & 0.71 & 1.27 & 2.34 \\
\hline Multifamily & North & 0.00 & 0.03 & 0.23 & 0.69 & 1.26 & 2.39 \\
\hline Multifamily & South & 0.00 & 0.03 & 0.23 & 0.69 & 1.26 & 2.39 \\
\hline \multicolumn{8}{|c|}{ Water Heat: Oil } \\
\hline Single Family & North & 0.01 & 0.44 & 2.80 & 8.29 & 15.77 & 32.06 \\
\hline Single Family & South & 0.01 & 0.44 & 2.80 & 8.29 & 15.77 & 32.06 \\
\hline Mobile Homes & North & 0.00 & 0.04 & 0.23 & 0.65 & 1.15 & 2.12 \\
\hline Mobile Homes & South & 0.00 & 0.05 & 0.28 & 0.79 & 1.41 & 2.59 \\
\hline Multifamily & North & 0.00 & 0.04 & 0.25 & 0.76 & 1.39 & 2.65 \\
\hline Multifamily & South & 0.00 & 0.04 & 0.25 & 0.76 & 1.39 & 2.65 \\
\hline
\end{tabular}


Table D.12. Equipment Market Shares (\%)

\begin{tabular}{|c|c|c|c|c|c|c|c|}
\hline Building Type & Region & 2001 & 2005 & 2010 & 2015 & 2020 & 2030 \\
\hline \multicolumn{8}{|c|}{ Space Heating: Electric Heat Pump } \\
\hline Single Family & North & 13 & 14 & 15 & 16 & 17 & 17 \\
\hline Single Family & South & 27 & 28 & 29 & 30 & 32 & 32 \\
\hline Mobile Homes & North & 13 & 14 & 15 & 16 & 17 & 17 \\
\hline Mobile Homes & South & 27 & 28 & 29 & 30 & 32 & 32 \\
\hline Multifamily & North & 13 & 14 & 15 & 16 & 17 & 17 \\
\hline Multifamily & South & 27 & 28 & 29 & 30 & 32 & 32 \\
\hline \multicolumn{8}{|c|}{ Space Heating: Electric Forced Air } \\
\hline Single Family & North & 7 & 8 & 9 & 10 & 11 & 11 \\
\hline Single Family & South & 12 & 13 & 15 & 17 & 19 & 19 \\
\hline Mobile Homes & North & 7 & 8 & 9 & 10 & 11 & 11 \\
\hline Mobile Homes & South & 12 & 13 & 15 & 17 & 19 & 19 \\
\hline Multifamily & North & 7 & 8 & 9 & 10 & 11 & 11 \\
\hline Multifamily & South & 12 & 13 & 15 & 17 & 19 & 19 \\
\hline \multicolumn{8}{|c|}{ Space Heating: Gas Furnace } \\
\hline Single Family & North & 56 & 52 & 47 & 41 & 36 & 36 \\
\hline Single Family & South & 47 & 43 & 38 & 32 & 27 & 27 \\
\hline Mobile Homes & North & 56 & 52 & 47 & 41 & 36 & 36 \\
\hline Mobile Homes & South & 47 & 43 & 38 & 32 & 27 & 27 \\
\hline Multifamily & North & 56 & 52 & 47 & 41 & 36 & 36 \\
\hline Multifamily & South & 47 & 43 & 38 & 32 & 27 & 27 \\
\hline \multicolumn{8}{|c|}{ Space Heating: Oil Furnace } \\
\hline Single Family & North & 3 & 3 & 3 & 3 & 3 & 3 \\
\hline Single Family & South & 1 & 1 & 1 & 1 & 1 & 1 \\
\hline Mobile Homes & North & 3 & 3 & 3 & 3 & 3 & 3 \\
\hline Mobile Homes & South & 1 & 1 & 1 & 1 & 1 & 1 \\
\hline Multifamily & North & 3 & 3 & 3 & 3 & 3 & 3 \\
\hline Multifamily & South & 1 & 1 & 1 & 1 & 1 & 1 \\
\hline \multicolumn{8}{|c|}{ Space Heating: High-Efficiency Gas Furnace } \\
\hline Single Family & North & 15 & 17 & 20 & 23 & 26 & 26 \\
\hline Single Family & South & 12 & 14 & 16 & 18 & 20 & 20 \\
\hline Mobile Homes & North & 15 & 17 & 20 & 23 & 26 & 26 \\
\hline Mobile Homes & South & 12 & 14 & 16 & 18 & 20 & 20 \\
\hline Multifamily & North & 15 & 17 & 20 & 23 & 26 & 26 \\
\hline Multifamily & South & 12 & 14 & 16 & 18 & 20 & 20 \\
\hline \multicolumn{8}{|c|}{ Space Heating: Gas Heat Pump } \\
\hline Single Family & North & 2 & 2 & 2 & 2 & 2 & 2 \\
\hline Single Family & South & 1 & 0 & 0 & 0 & 0 & 0 \\
\hline Mobile Homes & North & 2 & 2 & 2 & 2 & 2 & 2 \\
\hline Mobile Homes & South & 1 & 0 & 0 & 0 & 0 & 0 \\
\hline Multifamily & North & 2 & 2 & 2 & 2 & 2 & 2 \\
\hline Multifamily & South & 1 & 0 & 0 & 0 & 0 & 0 \\
\hline \multicolumn{8}{|c|}{ Space Cooling: Heat Pump } \\
\hline Single Family & North & 13 & 14 & 15 & 16 & 17 & 17 \\
\hline Single Family & South & 27 & 28 & 29 & 30 & 32 & 32 \\
\hline Mobile Homes & North & 13 & 14 & 15 & 16 & 17 & 17 \\
\hline Mobile Homes & South & 27 & 28 & 29 & 30 & 32 & 32 \\
\hline Multifamily & North & 13 & 14 & 15 & 16 & 17 & 17 \\
\hline Multifamily & South & 27 & 28 & 29 & 30 & 32 & 32 \\
\hline \multicolumn{8}{|c|}{ Space Cooling: Central Air Conditioning } \\
\hline Single Family & North & 56 & 55 & 54 & 53 & 52 & 52 \\
\hline Single Family & South & 58 & 57 & 55 & 54 & 53 & 53 \\
\hline
\end{tabular}




\begin{tabular}{|c|c|c|c|c|c|c|c|}
\hline Building Type & Region & 2001 & 2005 & 2010 & 2015 & 2020 & 2030 \\
\hline Mobile Homes & North & 56 & 55 & 54 & 53 & 52 & 52 \\
\hline Mobile Homes & South & 58 & 57 & 55 & 54 & 53 & 53 \\
\hline Multifamily & North & 56 & 55 & 54 & 53 & 52 & 52 \\
\hline Multifamily & South & 58 & 57 & 55 & 54 & 53 & 53 \\
\hline \multicolumn{8}{|c|}{ Space Cooling: Room Air } \\
\hline Single Family & North & 3 & 3 & 2 & 2 & 2 & 2 \\
\hline Single Family & South & 1 & 1 & 1 & 1 & 1 & 1 \\
\hline Mobile Homes & North & 3 & 3 & 2 & 2 & 2 & 2 \\
\hline Mobile Homes & South & 1 & 1 & 1 & 1 & 1 & 1 \\
\hline Multifamily & North & 3 & 3 & 2 & 2 & 2 & 2 \\
\hline Multifamily & South & 1 & 1 & 1 & 1 & 1 & 1 \\
\hline \multicolumn{8}{|c|}{ Space Cooling: Gas Heat Pump } \\
\hline Single Family & North & 2 & 2 & 2 & 2 & 2 & 2 \\
\hline Single Family & South & 1 & 0 & 0 & 0 & 0 & 0 \\
\hline Mobile Homes & North & 2 & 2 & 2 & 2 & 2 & 2 \\
\hline Mobile Homes & South & 1 & 0 & 0 & 0 & 0 & 0 \\
\hline Multifamily & North & 2 & 2 & 2 & 2 & 2 & 2 \\
\hline Multifamily & South & 1 & 0 & 0 & 0 & 0 & 0 \\
\hline \multicolumn{8}{|c|}{ Water Heat: Electric } \\
\hline Single Family & North & 23 & 23 & 22 & 22 & 22 & 22 \\
\hline Single Family & South & 23 & 23 & 22 & 22 & 22 & 22 \\
\hline Mobile Homes & North & 23 & 23 & 22 & 22 & 22 & 22 \\
\hline Mobile Homes & South & 23 & 23 & 22 & 22 & 22 & 22 \\
\hline Multifamily & North & 23 & 23 & 22 & 22 & 22 & 22 \\
\hline Multifamily & South & 23 & 23 & 22 & 22 & 22 & 22 \\
\hline \multicolumn{8}{|c|}{ Water Heat: Gas } \\
\hline Single Family & North & 73 & 73 & 73 & 74 & 74 & 74 \\
\hline Single Family & South & 73 & 73 & 73 & 74 & 74 & 74 \\
\hline Mobile Homes & North & 73 & 73 & 73 & 74 & 74 & 74 \\
\hline Mobile Homes & South & 73 & 73 & 73 & 74 & 74 & 74 \\
\hline Multifamily & North & 73 & 73 & 73 & 74 & 74 & 74 \\
\hline Multifamily & South & 73 & 73 & 73 & 74 & 74 & 74 \\
\hline \multicolumn{8}{|c|}{ Water Heat: Oil } \\
\hline Single Family & North & 5 & 5 & 4 & 4 & 4 & 4 \\
\hline Single Family & South & 5 & 5 & 4 & 4 & 4 & 4 \\
\hline Mobile Homes & North & 5 & 5 & 4 & 4 & 4 & 4 \\
\hline Mobile Homes & South & 5 & 5 & 4 & 4 & 4 & 4 \\
\hline Multifamily & North & 5 & 5 & 4 & 4 & 4 & 4 \\
\hline Multifamily & South & 5 & 5 & 4 & 4 & 4 & 4 \\
\hline
\end{tabular}


Table D.13. Actual Energy Savings (TBtu/yr)

\begin{tabular}{|c|c|c|c|c|c|c|c|}
\hline Building Type & Region & 2001 & 2005 & 2010 & 2015 & 2020 & 2030 \\
\hline \multicolumn{8}{|c|}{ Space Heating: Electric Heat Pump } \\
\hline Single Family & North & 0.00 & 0.06 & 0.39 & 1.22 & 2.46 & 5.01 \\
\hline Single Family & South & 0.00 & 0.04 & 0.30 & 0.91 & 1.85 & 3.77 \\
\hline Mobile Homes & North & 0.00 & 0.00 & 0.03 & 0.09 & 0.18 & 0.33 \\
\hline Mobile Homes & South & 0.00 & 0.00 & 0.03 & 0.09 & 0.17 & 0.30 \\
\hline Multifamily & North & 0.00 & 0.00 & 0.03 & 0.11 & 0.22 & 0.41 \\
\hline Multifamily & South & 0.00 & 0.00 & 0.03 & 0.08 & 0.16 & 0.31 \\
\hline \multicolumn{8}{|c|}{ Space Heating: Electric Forced Air } \\
\hline Single Family & North & 0.00 & 0.06 & 0.46 & 1.52 & 3.17 & 6.45 \\
\hline Single Family & South & 0.00 & 0.04 & 0.31 & 1.03 & 2.19 & 4.45 \\
\hline Mobile Homes & North & 0.00 & 0.01 & 0.04 & 0.12 & 0.23 & 0.43 \\
\hline Mobile Homes & South & 0.00 & 0.00 & 0.03 & 0.10 & 0.20 & 0.36 \\
\hline Multifamily & North & 0.00 & 0.01 & 0.04 & 0.14 & 0.28 & 0.53 \\
\hline Multifamily & South & 0.00 & 0.00 & 0.03 & 0.09 & 0.19 & 0.37 \\
\hline \multicolumn{8}{|c|}{ Space Heating: Gas Furnace } \\
\hline Single Family & North & 0.02 & 0.53 & 3.09 & 7.97 & 13.30 & 27.05 \\
\hline Single Family & South & 0.01 & 0.18 & 1.00 & 2.49 & 3.99 & 8.12 \\
\hline Mobile Homes & North & 0.00 & 0.05 & 0.25 & 0.62 & 0.97 & 1.79 \\
\hline Mobile Homes & South & 0.00 & 0.02 & 0.10 & 0.24 & 0.36 & 0.66 \\
\hline Multifamily & North & 0.00 & 0.04 & 0.28 & 0.73 & 1.17 & 2.23 \\
\hline Multifamily & South & 0.00 & 0.01 & 0.09 & 0.23 & 0.35 & 0.67 \\
\hline \multicolumn{8}{|c|}{ Space Heating: Oil Furnace } \\
\hline Single Family & North & 0.00 & 0.03 & 0.20 & 0.58 & 1.11 & 2.25 \\
\hline Single Family & South & 0.00 & 0.00 & 0.03 & 0.08 & 0.15 & 0.30 \\
\hline Mobile Homes & North & 0.00 & 0.00 & 0.02 & 0.05 & 0.08 & 0.15 \\
\hline Mobile Homes & South & 0.00 & 0.00 & 0.00 & 0.01 & 0.01 & 0.02 \\
\hline Multifamily & North & 0.00 & 0.00 & 0.02 & 0.05 & 0.10 & 0.19 \\
\hline Multifamily & South & 0.00 & 0.00 & 0.00 & 0.01 & 0.01 & 0.02 \\
\hline \multicolumn{8}{|c|}{ Space Heating: High-Efficiency Gas Furnace } \\
\hline Single Family & North & 0.00 & 0.15 & 1.11 & 3.79 & 8.15 & 16.56 \\
\hline Single Family & South & 0.00 & 0.05 & 0.36 & 1.19 & 2.51 & 5.10 \\
\hline Mobile Homes & North & 0.00 & 0.01 & 0.09 & 0.30 & 0.60 & 1.09 \\
\hline Mobile Homes & South & 0.00 & 0.01 & 0.04 & 0.11 & 0.22 & 0.41 \\
\hline Multifamily & North & 0.00 & 0.01 & 0.10 & 0.35 & 0.72 & 1.37 \\
\hline Multifamily & South & 0.00 & 0.00 & 0.03 & 0.11 & 0.22 & 0.42 \\
\hline \multicolumn{8}{|c|}{ Space Heating: Gas Heat Pump } \\
\hline Single Family & North & 0.00 & 0.01 & 0.07 & 0.22 & 0.41 & 0.84 \\
\hline Single Family & South & 0.00 & 0.00 & 0.00 & 0.00 & 0.00 & 0.00 \\
\hline Mobile Homes & North & 0.00 & 0.00 & 0.01 & 0.02 & 0.03 & 0.06 \\
\hline Mobile Homes & South & 0.00 & 0.00 & 0.00 & 0.00 & 0.00 & 0.00 \\
\hline Multifamily & North & 0.00 & 0.00 & 0.01 & 0.02 & 0.04 & 0.07 \\
\hline Multifamily & South & 0.00 & 0.00 & 0.00 & 0.00 & 0.00 & 0.00 \\
\hline \multicolumn{8}{|c|}{ Space Cooling: Heat Pump } \\
\hline Single Family & North & 0.00 & 0.01 & 0.05 & 0.17 & 0.34 & 0.69 \\
\hline Single Family & South & 0.00 & 0.02 & 0.16 & 0.50 & 1.01 & 2.06 \\
\hline Mobile Homes & North & 0.00 & 0.00 & 0.00 & 0.01 & 0.02 & 0.05 \\
\hline Mobile Homes & South & 0.00 & 0.00 & 0.02 & 0.05 & 0.09 & 0.17 \\
\hline Multifamily & North & 0.00 & 0.00 & 0.00 & 0.02 & 0.03 & 0.06 \\
\hline Multifamily & South & 0.00 & 0.00 & 0.01 & 0.05 & 0.09 & 0.17 \\
\hline \multicolumn{8}{|c|}{ Space Cooling: Central Air Conditioning } \\
\hline Single Family & North & 0.00 & 0.02 & 0.14 & 0.42 & 0.78 & 1.59 \\
\hline Single Family & South & 0.00 & 0.04 & 0.23 & 0.67 & 1.26 & 2.56 \\
\hline
\end{tabular}

Appendix D - 24 


\begin{tabular}{|c|c|c|c|c|c|c|c|}
\hline Building Type & Region & 2001 & 2005 & 2010 & 2015 & 2020 & 2030 \\
\hline Mobile Homes & North & 0.00 & 0.00 & 0.01 & 0.03 & 0.06 & 0.11 \\
\hline Mobile Homes & South & 0.00 & 0.00 & 0.02 & 0.06 & 0.11 & 0.21 \\
\hline Multifamily & North & 0.00 & 0.00 & 0.01 & 0.04 & 0.07 & 0.13 \\
\hline Multifamily & South & 0.00 & 0.00 & 0.02 & 0.06 & 0.11 & 0.21 \\
\hline \multicolumn{8}{|c|}{ Space Cooling: Room Air } \\
\hline Single Family & North & 0.00 & 0.00 & 0.01 & 0.02 & 0.04 & 0.09 \\
\hline Single Family & South & 0.00 & 0.00 & 0.01 & 0.02 & 0.04 & 0.07 \\
\hline Mobile Homes & North & 0.00 & 0.00 & 0.00 & 0.00 & 0.00 & 0.01 \\
\hline Mobile Homes & South & 0.00 & 0.00 & 0.00 & 0.00 & 0.00 & 0.01 \\
\hline Multifamily & North & 0.00 & 0.00 & 0.00 & 0.00 & 0.00 & 0.01 \\
\hline Multifamily & South & 0.00 & 0.00 & 0.00 & 0.00 & 0.00 & 0.01 \\
\hline \multicolumn{8}{|c|}{ Space Cooling: Gas Heat Pump } \\
\hline Single Family & North & 0.00 & 0.00 & 0.02 & 0.07 & 0.12 & 0.25 \\
\hline Single Family & South & 0.00 & 0.00 & 0.00 & 0.00 & 0.00 & 0.00 \\
\hline Mobile Homes & North & 0.00 & 0.00 & 0.00 & 0.01 & 0.01 & 0.02 \\
\hline Mobile Homes & South & 0.00 & 0.00 & 0.00 & 0.00 & 0.00 & 0.00 \\
\hline Multifamily & North & 0.00 & 0.00 & 0.00 & 0.01 & 0.01 & 0.02 \\
\hline Multifamily & South & 0.00 & 0.00 & 0.00 & 0.00 & 0.00 & 0.00 \\
\hline \multicolumn{8}{|c|}{ Water Heat: Electric } \\
\hline Single Family & North & 0.00 & 0.06 & 0.37 & 1.10 & 2.09 & 4.25 \\
\hline Single Family & South & 0.00 & 0.06 & 0.37 & 1.10 & 2.09 & 4.25 \\
\hline Mobile Homes & North & 0.00 & 0.01 & 0.03 & 0.09 & 0.15 & 0.28 \\
\hline Mobile Homes & South & 0.00 & 0.01 & 0.04 & 0.10 & 0.19 & 0.34 \\
\hline Multifamily & North & 0.00 & 0.00 & 0.03 & 0.10 & 0.18 & 0.35 \\
\hline Multifamily & South & 0.00 & 0.00 & 0.03 & 0.10 & 0.18 & 0.35 \\
\hline \multicolumn{8}{|c|}{ Water Heat: Gas } \\
\hline Single Family & North & 0.01 & 0.29 & 1.85 & 5.54 & 10.54 & 21.43 \\
\hline Single Family & South & 0.01 & 0.29 & 1.85 & 5.54 & 10.54 & 21.43 \\
\hline Mobile Homes & North & 0.00 & 0.03 & 0.15 & 0.43 & 0.77 & 1.42 \\
\hline Mobile Homes & South & 0.00 & 0.03 & 0.19 & 0.53 & 0.94 & 1.73 \\
\hline Multifamily & North & 0.00 & 0.02 & 0.17 & 0.51 & 0.93 & 1.77 \\
\hline Multifamily & South & 0.00 & 0.02 & 0.17 & 0.51 & 0.93 & 1.77 \\
\hline \multicolumn{8}{|c|}{ Water Heat: Oil } \\
\hline Single Family & North & 0.00 & 0.02 & 0.11 & 0.33 & 0.63 & 1.28 \\
\hline Single Family & South & 0.00 & 0.02 & 0.11 & 0.33 & 0.63 & 1.28 \\
\hline Mobile Homes & North & 0.00 & 0.00 & 0.01 & 0.03 & 0.05 & 0.08 \\
\hline Mobile Homes & South & 0.00 & 0.00 & 0.01 & 0.03 & 0.06 & 0.10 \\
\hline Multifamily & North & 0.00 & 0.00 & 0.01 & 0.03 & 0.06 & 0.11 \\
\hline Multifamily & South & 0.00 & 0.00 & 0.01 & 0.03 & 0.06 & 0.11 \\
\hline
\end{tabular}

Table D.14. Energy Savings by Fuel Type (TBtu/yr)

\begin{tabular}{|l|c|c|c|c|c|c|}
\hline \multicolumn{1}{|c|}{ Fuel Type } & $\mathbf{2 0 0 1}$ & $\mathbf{2 0 0 5}$ & $\mathbf{2 0 1 0}$ & $\mathbf{2 0 1 5}$ & $\mathbf{2 0 2 0}$ & $\mathbf{2 0 3 0}$ \\
\hline Delivered Electricity & 0.0 & 0.5 & 3.3 & 10.2 & 20.3 & 40.7 \\
\hline Primary Electricity & 0.0 & 1.3 & 8.2 & 24.4 & 45.2 & 90.8 \\
\hline Natural Gas & 0.1 & 1.8 & 11.0 & 31.5 & 57.8 & 116.2 \\
\hline Oil & 0.0 & 0.1 & 0.5 & 1.6 & 2.9 & 5.9 \\
\hline Total Primary & 0.1 & 3.2 & 19.7 & 57.5 & 106.0 & 213.0 \\
\hline
\end{tabular}


Table D.15. Refrigerator Efficiency and Costs: AEO 2000

\begin{tabular}{|c|c|c|c|c|c|}
\hline Model & $\begin{array}{c}\text { Initial } \\
\text { Year }\end{array}$ & $\begin{array}{c}\text { Ending } \\
\text { Year }\end{array}$ & $\begin{array}{c}\text { Annual } \\
\text { Consumption } \\
(\mathbf{k W h})\end{array}$ & $\begin{array}{c}\text { Installed } \\
\text { Cost } \\
(\mathbf{1 9 9 8} \mathbf{\$})\end{array}$ & $\begin{array}{c}\text { Retail } \\
\text { Cost } \\
(\mathbf{1 9 9 8} \mathbf{)})\end{array}$ \\
\hline 1 & 1997 & 2001 & 690 & 530 & 480 \\
\hline 1 & 2002 & 2020 & 478 & 530 & 480 \\
\hline 2 & 1997 & 2001 & 660 & 550 & 500 \\
\hline 2 & 2002 & 2020 & 460 & 550 & 500 \\
\hline 3 & 1993 & 2001 & 518 & 850 & 800 \\
\hline 3 & 2002 & 2020 & 460 & 550 & 500 \\
\hline 3 & 2005 & 2020 & 400 & 700 & 650 \\
\hline 4 & 1993 & 2001 & 843 & 1313.8 & 1313.8 \\
\hline 4 & 2002 & 2020 & 577 & 1313.8 & 1313.8 \\
\hline
\end{tabular}

Table D.16. Refrigerator Efficiency and Costs: GPRA Baseline

\begin{tabular}{|l|c|c|c|c|c|}
\hline Model & $\begin{array}{c}\text { Initial } \\
\text { Year }\end{array}$ & $\begin{array}{c}\text { Ending } \\
\text { Year }\end{array}$ & $\begin{array}{c}\text { Annual } \\
\text { Consumption } \\
(\mathbf{k W h})\end{array}$ & $\begin{array}{c}\text { Installed } \\
\text { Cost } \\
(\mathbf{1 9 9 8} \$ \mathbf{)}\end{array}$ & $\begin{array}{c}\text { Retail } \\
\text { Cost } \\
(\mathbf{1 9 9 8} \mathbf{\text { \$) }}\end{array}$ \\
\hline 1 & 1997 & 2001 & 690 & 530 & 480 \\
\hline 1 & 2002 & 2020 & 478 & 580 & 480 \\
\hline 2 & 1997 & 2001 & 660 & 550 & 500 \\
\hline 2 & 2002 & 2020 & 460 & 600 & 550 \\
\hline 3 & 1997 & 2001 & 518 & 850 & 800 \\
\hline 3 & 2002 & 2020 & 460 & 600 & 550 \\
\hline 3 & 2005 & 2020 & 400 & 700 & 650 \\
\hline 4 & 1997 & 2001 & 843 & 1313.8 & 1313.8 \\
\hline 4 & 2002 & 2020 & 577 & 1313.8 & 1313.8 \\
\hline
\end{tabular}

Table D.17. Energy Star Program - Refrigerators (market share of 400-kWh/yr units)

\begin{tabular}{|c|c|c|c|c|}
\hline \multirow{2}{*}{$\begin{array}{c}\text { Census } \\
\text { Division }\end{array}$} & \multicolumn{2}{|c|}{ 2005 } & \multicolumn{2}{c|}{ 2010 } \\
\cline { 2 - 5 } & Baseline & $\begin{array}{c}\text { Energy } \\
\text { Star }\end{array}$ & Baseline & $\begin{array}{c}\text { Energy } \\
\text { Star }\end{array}$ \\
\hline 1 & .0427 & .2068 & .0426 & .2064 \\
\hline 2 & .0409 & .2003 & .0400 & .1971 \\
\hline 3 & .0337 & .1727 & .0329 & .1698 \\
\hline 4 & .0326 & .1687 & .0327 & .1689 \\
\hline 5 & .0342 & .1748 & .0341 & .1744 \\
\hline 6 & .0330 & .1702 & .0329 & .1696 \\
\hline 7 & .0329 & .1698 & .0322 & .1668 \\
\hline 8 & .0355 & .1801 & .0356 & .1805 \\
\hline 9 & .0354 & .1793 & .0357 & .1807 \\
\hline
\end{tabular}


Table D.18. Original and Revised NEMS Inputs for Clothes Washers

\begin{tabular}{|c|c|c|c|c|c|c|}
\hline Original NEMS Inputs \\
\hline Technology & $\begin{array}{c}\text { Start } \\
\text { Yr }\end{array}$ & $\begin{array}{c}\text { End } \\
\text { Yr }\end{array}$ & $\begin{array}{c}\text { Water } \\
\text { Coeff. }\end{array}$ & $\begin{array}{c}\text { Energy } \\
\text { Factor }\end{array}$ & $\begin{array}{c}\text { Installed } \\
\text { Cost }\end{array}$ & Type \\
\hline 1 & 1997 & 2020 & .67 & 2.71 & $\$ 490$ & V-Axis \\
\hline 2 & 1997 & 2004 & .67 & 3.88 & $\$ 645$ & V-Axis \\
\hline 3 & 2005 & 2020 & .67 & 3.88 & $\$ 590$ & V-Axis \\
\hline 4 & 1997 & 2020 & .24 & 4.45 & $\$ 800$ & H-Axis \\
\hline 5 & 2005 & 2020 & .24 & 5.27 & $\$ 800$ & H-Axis \\
\hline 6 & 2015 & 2020 & .24 & 5.44 & $\$ 800$ & H-Axis \\
\hline \multicolumn{7}{|l|}{} \\
\hline Revised NEMS Inputs \\
\hline 1 & 1997 & 2020 & 2 & 2.71 & $\$ 490$ & V-Axis \\
\hline 2 & 1997 & 2004 & 2 & 3.88 & $\$ 645$ & V-Axis \\
\hline 3 & 2005 & 2020 & 2 & 3.88 & $\$ 590$ & V-Axis \\
\hline 4 & 1997 & 2020 & .4 & 4.45 & $\$ 800$ & H-Axis \\
\hline 5 & 2005 & 2020 & .4 & 5.27 & $\$ 800$ & H-Axis \\
\hline 6 & 2015 & 2020 & .4 & 5.44 & $\$ 800$ & H-Axis \\
\hline
\end{tabular}

Table D.19. NEMS-Generated Shares of Clothes Washers by Technology

\begin{tabular}{|c|c|c|c|c|}
\hline \multirow{2}{*}{$\begin{array}{c}\text { Census } \\
\text { Division }\end{array}$} & \multicolumn{2}{|c|}{2005} & \multicolumn{2}{c|}{ 2010 } \\
\cline { 2 - 5 } & Baseline & $\begin{array}{c}\text { Energy } \\
\text { Star }\end{array}$ & Baseline & $\begin{array}{c}\text { Energy } \\
\text { Star }\end{array}$ \\
\hline 1 & .0000 & .0927 & .0000 & .0923 \\
\hline 2 & .0000 & .0904 & .0000 & .0900 \\
\hline 3 & .0000 & .0814 & .0000 & .0804 \\
\hline 4 & .0000 & .0794 & .0000 & .0794 \\
\hline 5 & .0000 & .0813 & .0000 & .0812 \\
\hline 6 & .0000 & .0799 & .0000 & .0797 \\
\hline 7 & .0000 & .0801 & .0000 & .0791 \\
\hline 8 & .0000 & .0831 & .0000 & .0833 \\
\hline 9 & .0000 & .0826 & .0000 & .0830 \\
\hline $\begin{array}{l}\text { Notes: Results shown are for new housing units; replace- } \\
\text { ment shares are generally within 0.5\% of values shown here. }\end{array}$ \\
\hline
\end{tabular}

Table D.20. Key NEMS Inputs for Electric Water Heaters (AEO 2000)

\begin{tabular}{|c|c|c|c|c|l|}
\hline Technology & $\begin{array}{c}\text { Start } \\
\text { Yr }\end{array}$ & $\begin{array}{c}\text { End } \\
\text { Yr }\end{array}$ & $\begin{array}{c}\text { Energy } \\
\text { Factor }\end{array}$ & $\begin{array}{c}\text { Installed } \\
\text { Cost }\end{array}$ & Type \\
\hline 1 & 1997 & 2020 & .86 & $\$ 350$ & Resistance \\
\hline 2 & 1997 & 2020 & .88 & $\$ 350$ & Resistance \\
\hline 3 & 1997 & 2020 & .95 & $\$ 575$ & Resistance \\
\hline 4 & 1997 & 2020 & 2.60 & $\$ 1,025$ & Heat Pump \\
\hline 5 & 1997 & 2020 & 2.00 & $\$ 2,600$ & Heat Pump \\
\hline 6 & 2005 & 2020 & .89 & $\$ 350$ & Resistance \\
\hline 7 & 2005 & 2020 & .96 & $\$ 475$ & Resistance \\
\hline 8 & 2005 & 2020 & 2.00 & $\$ 900$ & Heat Pump \\
\hline 9 & 2015 & 2020 & .90 & $\$ 400$ & Resistance \\
\hline 10 & 2015 & 2020 & .96 & $\$ 425$ & Resistance \\
\hline 11 & 2015 & 2020 & 2.20 & $\$ 800$ & Heat Pump \\
\hline
\end{tabular}


Table D.21. NEMS Results for Energy Star Electric Water Heaters (national market shares for new single-family homes)

\begin{tabular}{|c|c|c|c|c|}
\hline & \multicolumn{2}{|c|}{$\mathbf{2 0 0 5}$} & \multicolumn{2}{c|}{$\mathbf{2 0 1 0}$} \\
\hline $\begin{array}{c}\text { Efficiency } \\
\text { Level }\end{array}$ & Baseline & $\begin{array}{c}\text { Energy } \\
\text { Star }\end{array}$ & Baseline & $\begin{array}{c}\text { Energy } \\
\text { Star }\end{array}$ \\
\hline 0.95 & 0.011 & 0.054 & 0.011 & 0.054 \\
\hline 0.96 & 0.056 & 0.128 & 0.056 & 0.127 \\
\hline Total & 0.0670 & 0.1820 & 0.0670 & 0.1810 \\
\hline
\end{tabular}

Note: Results shown are for new, single-family housing units; replacement shares are generally within $2 \%$ of the values shown here.

Table D.22. Key NEMS Inputs for Gas Water Heaters

\begin{tabular}{|c|l|l|c|c|l|}
\hline Technology & Start Yr & End Yr & $\begin{array}{c}\text { Energy } \\
\text { Factor }\end{array}$ & $\begin{array}{c}\text { Installed } \\
\text { Cost }\end{array}$ & Type \\
\hline 1 & 1997 & 2020 & .54 & $\$ 340$ & Non-Condensing \\
\hline 2 & 1997 & 2020 & .58 & $\$ 370$ & Non-Condensing \\
\hline 3 & 1997 & 2004 & .6 & $\$ 400$ & Non-Condensing \\
\hline 4 & 2005 & 2020 & .6 & $\$ 375$ & Non-Condensing \\
\hline 5 & 1997 & 2020 & .86 & $\$ 2360$ & Non-Condensing \\
\hline 6 & 2005 & 2014 & .86 & $\$ 2000$ & Condensing \\
\hline 7 & 2015 & 2020 & .86 & $\$ 1800$ & Condensing \\
\hline 8 & 2005 & 2014 & .63 & $\$ 450$ & Condensing \\
\hline 9 & 2015 & 2020 & .63 & $\$ 425$ & Non-Condensing \\
\hline 10 & 2015 & 2020 & .7 & $\$ 500$ & Non-Condensing \\
\hline
\end{tabular}

Table D.23. NEMS Results for Energy Star Gas Water Heaters (national market shares for new, single-family homes)

\begin{tabular}{|c|c|c|c|c|}
\hline $\begin{array}{c}\text { Efficiency } \\
\text { Level }\end{array}$ & \multicolumn{2}{|c|}{$\mathbf{2 0 0 5}$} & \multicolumn{2}{c|}{$\mathbf{2 0 1 0}$} \\
\cline { 2 - 5 } & Baseline & $\begin{array}{c}\text { Energy } \\
\text { Star }\end{array}$ & Baseline & $\begin{array}{c}\text { Energy } \\
\text { Star }\end{array}$ \\
\hline 0.60 & 0.307 & 0.387 & 0.315 & 0.384 \\
\hline 0.63 & 0.011 & 0.068 & 0.011 & 0.066 \\
\hline Total & 0.318 & 0.455 & 0.326 & 0.450 \\
\hline
\end{tabular}


Table D.24. NEMS Input Parameters for Room Air Conditioners

\begin{tabular}{|c|c|c|c|c|}
\hline Technology & $\begin{array}{c}\text { Start } \\
\text { Year }\end{array}$ & End Year & SEER & $\begin{array}{c}\text { Installed } \\
\text { Cost }\end{array}$ \\
\hline \multicolumn{5}{|c|}{ AEO 2000 and GPRA Baseline } \\
\hline 1 & 1997 & 2000 & 2.55 & $\$ 450$ \\
\hline 2 & 2001 & 2020 & 2.83 & $\$ 450$ \\
\hline 3 & 1997 & 2004 & 2.93 & $\$ 500$ \\
\hline 4 & 2005 & 2020 & 2.93 & $\$ 490$ \\
\hline 5 & 1997 & 2020 & 3.43 & $\$ 760$ \\
\hline 6 & 2005 & 2020 & 3.43 & $\$ 760$ \\
\hline 7 & 2015 & 2020 & 3.22 & $\$ 600$ \\
\hline \multicolumn{5}{|c|}{ Revised NEMS Inputs for Room Air Conditioners } \\
\hline 1 & 1997 & 2000 & 2.55 & $\$ 450$ \\
\hline 2 & 2001 & 2020 & 2.83 & $\$ 450$ \\
\hline 3 & 1997 & 2004 & 3.11 & $\$ 530$ \\
\hline 4 & 2005 & 2020 & 3.11 & $\$ 520$ \\
\hline 5 & 1997 & 2020 & 3.43 & $\$ 760$ \\
\hline 6 & 2005 & 2020 & 3.52 & $\$ 760$ \\
\hline 7 & 2015 & 2020 & 3.22 & $\$ 600$ \\
\hline
\end{tabular}

Table D.25. NEMS Results for Energy Star Room Air Conditioners (market shares for new, single-family homes)

\begin{tabular}{|c|c|c|c|c|}
\hline & \multicolumn{2}{|c|}{2005} & \multicolumn{2}{c|}{2010} \\
\hline $\begin{array}{c}\text { Census } \\
\text { Division }\end{array}$ & Baseline & $\begin{array}{c}\text { Energy } \\
\text { Star }\end{array}$ & Baseline & $\begin{array}{c}\text { Energy } \\
\text { Star }\end{array}$ \\
\hline 1 & .0083 & .1301 & .0083 & .1299 \\
\hline 2 & .0085 & .1323 & .0085 & .1321 \\
\hline 3 & .0085 & .1319 & .0084 & .1314 \\
\hline 4 & .0084 & .1314 & .0084 & .1312 \\
\hline 5 & .0091 & .1396 & .0091 & .1395 \\
\hline 6 & .0091 & .1402 & .0091 & .1398 \\
\hline 7 & .0101 & .1522 & .0099 & .1501 \\
\hline 8 & .0085 & .1327 & .0085 & .1327 \\
\hline 9 & .0084 & .1314 & .0084 & .1317 \\
\hline
\end{tabular}

Table D.26. Key NEMS Data Inputs for Dishwashers

\begin{tabular}{|c|l|l|l|l|l|}
\hline Technology & $\begin{array}{c}\text { Start } \\
\text { Year }\end{array}$ & $\begin{array}{c}\text { End } \\
\text { Year }\end{array}$ & $\begin{array}{c}\text { Water } \\
\text { Co-efficiency }\end{array}$ & $\begin{array}{c}\text { Energy } \\
\text { Factor }\end{array}$ & $\begin{array}{c}\text { Installed } \\
\text { Cost }\end{array}$ \\
\hline 1 & 1997 & 2020 & .80 & .46 & $\$ 350$ \\
\hline 2 & 1997 & 2004 & .80 & .59 & $\$ 500$ \\
\hline 3 & 2005 & 2020 & .80 & .59 & $\$ 450$ \\
\hline 4 & 1997 & 2004 & .78 & .71 & $\$ 700$ \\
\hline 5 & 2005 & 2014 & .78 & .71 & $\$ 600$ \\
\hline 6 & 2015 & 2020 & .78 & .71 & $\$ 500$ \\
\hline 7 & 2015 & 2020 & .80 & .60 & $\$ 400$ \\
\hline
\end{tabular}


Table D.27. Energy Star Program Dishwashers (estimated market shares for high-efficiency dishwashers)

\begin{tabular}{|c|c|c|c|c|c|c|c|c|}
\hline \multirow{2}{*}{$\begin{array}{c}\text { Census } \\
\text { Division }\end{array}$} & \multicolumn{4}{|c|}{ 2005 } & \multicolumn{3}{c|}{2010} \\
\cline { 2 - 8 } & Baseline & \multicolumn{2}{c|}{ Energy Star } & \multicolumn{2}{c|}{ Baseline } & \multicolumn{2}{c|}{ Energy Star } \\
\hline & $\mathrm{EF}=.59$ & $\mathrm{EF}=.71$ & $\mathrm{EF}=.59$ & $\mathrm{EF}=.71$ & $\mathrm{EF}=.59$ & $\mathrm{EF}=.71$ & $\mathrm{EF}=.59$ & $\mathrm{EF}=.71$ \\
\hline 1 & .0683 & .0012 & .2219 & .0322 & .0682 & .0012 & .2217 & .0321 \\
\hline 2 & .0678 & .0012 & .2207 & .0318 & .0677 & .0012 & .2204 & .0317 \\
\hline 3 & .0659 & .0011 & .2157 & .0305 & .0656 & .0011 & .2151 & .0304 \\
\hline 4 & .0654 & .0011 & .2146 & .0302 & .0654 & .0011 & .2145 & .0304 \\
\hline 5 & .0658 & .0011 & .2156 & .0305 & 30654 & .0011 & .2145 & .0304 \\
\hline 6 & .0655 & .0011 & .2148 & .0303 & .0658 & .0011 & .2156 & .0305 \\
\hline 7 & .0656 & .0011 & .2150 & .0303 & .0653 & .0011 & .2144 & .0302 \\
\hline 8 & .0662 & .0011 & .2166 & .0308 & .0663 & .0012 & .2168 & .0308 \\
\hline 9 & .0661 & .0011 & .2164 & .0307 & .0663 & .0012 & .2169 & .0308 \\
\hline
\end{tabular}

Table D.28. Key NEMS Inputs for Electric Water Heaters -

\begin{tabular}{|c|c|c|c|c|l|}
\hline Technology & $\begin{array}{c}\text { Start } \\
\text { Year }\end{array}$ & End Year & $\begin{array}{c}\text { Energy } \\
\text { Factor }\end{array}$ & $\begin{array}{c}\text { Installed } \\
\text { Cost }\end{array}$ & Type \\
\hline 1 & 1197 & 2003 & 0.86 & $\$ 350$ & Resistance \\
\hline 2 & 1997 & 2003 & 0.88 & $\$ 350$ & Resistance \\
\hline $2 a$ & 2004 & 2020 & 0.89 & $\$ 350$ & Resistance \\
\hline 3 & 1997 & 2020 & 0.95 & $\$ 575$ & Resistance \\
\hline 4 & 1997 & 2020 & 2.60 & $\$ 1,025$ & Heat Pump \\
\hline 5 & 1997 & 2020 & 2.00 & $\$ 2,600$ & Heat Pump \\
\hline 6 & 1997 & 2020 & 0.90 & $\$ 360$ & Resistance \\
\hline 7 & 2005 & 2020 & 0.96 & $\$ 475$ & Resistance \\
\hline 8 & 2004 & 2009 & 2.00 & $\$ 700$ & Heat Pump \\
\hline $8 a$ & 2010 & 2014 & 2.10 & $\$ 650$ & Heat Pump \\
\hline 9 & 2015 & 2020 & 0.90 & $\$ 400$ & Resistance \\
\hline 10 & 2015 & 2020 & 0.96 & $\$ 425$ & Resistance \\
\hline 11 & 2015 & 2020 & 2.20 & $\$ 600$ & Heat Pump* \\
\hline \multicolumn{5}{|l|}{} & \multicolumn{5}{l}{} \\
\hline${ }^{*}$ Emerging Technologies program.
\end{tabular}

Table D.29. NEMS Results for Emerging Technologies Program's Heat Pump Water Heaters (national market shares for new single-family homes)

\begin{tabular}{|c|c|c|}
\hline Year & $\begin{array}{c}\text { Market Share: } \\
\text { AEO 2000 Discount } \\
\text { Rate }\end{array}$ & $\begin{array}{c}\text { Market Share: } \\
\text { Adjusted Discount } \\
\text { Rate (Energy Star) }\end{array}$ \\
\hline 2004 & 0.024 & 0.040 \\
\hline 2005 & 0.012 & 0.031 \\
\hline 2006 & 0.012 & 0.050 \\
\hline 2007 & 0.012 & 0.077 \\
\hline 2008 & 0.012 & 0.116 \\
\hline 2010 & 0.028 & 0.239 \\
\hline 2015 & 0.047 & 0.241 \\
\hline 2020 & 0.048 & 0.243 \\
\hline
\end{tabular}


Table D.30. Key NEMS Inputs for Gas Water Heaters

\begin{tabular}{|c|c|c|c|c|l|}
\hline Technology & Start Yr & End Yr & Energy Factor & Installed Cost & \multicolumn{1}{|c|}{ Type } \\
\hline 1 & 1997 & 2003 & 0.54 & $\$ 340$ & Non-condensing \\
\hline 2 & 1997 & 2003 & 0.58 & $\$ 370$ & Non-condensing \\
\hline 3 & 1997 & 2004 & 0.60 & $\$ 400$ & Non-condensing \\
\hline 4 & 2005 & 2020 & 0.60 & $\$ 375$ & Non-condensing \\
\hline 5 & 1997 & 2020 & 0.86 & $\$ 2,360$ & Condensing \\
\hline 6 & 2005 & 2014 & 0.86 & $\$ 2,000$ & Condensing \\
\hline 7 & 2015 & 2020 & 0.86 & $\$ 1,800$ & Condensing \\
\hline 8 & 2005 & 2014 & 0.63 & $\$ 450$ & Non-condensing \\
\hline 9 & 2015 & 2020 & 0.63 & $\$ 425$ & Non-condensing \\
\hline 10 & 2015 & 2020 & 0.70 & $\$ 500$ & Non-condensing \\
\hline 11 & 2005 & 2009 & 0.80 & $\$ 550$ & Condensing--ET Pgm \\
\hline 12 & 2010 & 2020 & 0.8 & $\$ 525$ & Condensing--ET Pgm \\
\hline
\end{tabular}

Table D.31. NEMS Results for Energy Star Gas Water Heaters (national market shares for new single-family homes)

\begin{tabular}{|c|c|c|}
\hline Year & $\begin{array}{c}\text { Market Share: } \\
\text { AEO 2000 } \\
\text { Discount Rate }\end{array}$ & $\begin{array}{c}\text { Market Share: } \\
\text { Adjusted } \\
\text { Discount Rate }\end{array}$ \\
\hline 2005 & 0.003 & 0.009 \\
\hline 2006 & 0.003 & 0.015 \\
\hline 2007 & 0.003 & 0.024 \\
\hline 2008 & 0.003 & 0.038 \\
\hline 2010 & 0.011 & 0.129 \\
\hline 2015 & 0.009 & 0.100 \\
\hline 2020 & 0.010 & 0.106 \\
\hline
\end{tabular}


Table D.32. Building Simulation Parameters

\begin{tabular}{|c|c|c|c|}
\hline Building Type & $\begin{array}{c}\text { Building Size } \\
\left(\mathrm{ft}^{2}\right)\end{array}$ & $\begin{array}{c}\text { Vintage (Year } \\
\text { Built) }\end{array}$ & Location \\
\hline Assembly & \multirow{10}{*}{$\begin{array}{l}4000 \\
7500 \\
17500 \\
37500 \\
75000 \\
125000\end{array}$} & \multirow{13}{*}{$\begin{array}{l}1940 \\
1953 \\
1967 \\
1976 \\
1983 \\
2000\end{array}$} & \multirow{13}{*}{$\begin{array}{l}\text { Denver, Colorado } \\
\text { Detroit, Michigan } \\
\text { Fresno, California } \\
\text { Knoxville, Tennessee } \\
\text { Los Angeles, California } \\
\text { Minneapolis, Minnesota } \\
\text { Phoenix, Arizona } \\
\text { Providence, Rhode Island } \\
\text { Seattle, Washington } \\
\text { Shreveport, Louisiana } \\
\text { Tampa, Florida }\end{array}$} \\
\hline Education & & & \\
\hline Food Sales & & & \\
\hline Food Service & & & \\
\hline Healthcare & & & \\
\hline Lodging & & & \\
\hline Mercantile and Service & & & \\
\hline Office & & & \\
\hline Warehouse & & & \\
\hline $\begin{array}{l}\text { Other Commercial } \\
\text { Buildings }\end{array}$ & & & \\
\hline Single Family & \multirow[b]{2}{*}{$\begin{array}{l}600 \\
800 \\
1300 \\
1800 \\
2200 \\
3000^{*} \\
\end{array}$} & & \\
\hline Mobile Home & & & \\
\hline Multifamily & $\begin{array}{l}14309 \\
19079 \\
31003 \\
42927 \\
52466 \\
71545\end{array}$ & & \\
\hline
\end{tabular}

\section{D.33. Weights Given to Each City for Each Census Region (\%)}

\begin{tabular}{|l|c|c|c|c|c|c|c|c|c|}
\hline \multicolumn{1}{|c|}{ City } & $\begin{array}{c}\text { New } \\
\text { England }\end{array}$ & $\begin{array}{c}\text { Mid } \\
\text { Atlantic }\end{array}$ & $\begin{array}{c}\text { East } \\
\text { North } \\
\text { Central }\end{array}$ & $\begin{array}{c}\text { West } \\
\text { North } \\
\text { Central }\end{array}$ & $\begin{array}{c}\text { South } \\
\text { Atlantic }\end{array}$ & $\begin{array}{c}\text { East } \\
\text { South } \\
\text { Central }\end{array}$ & $\begin{array}{c}\text { West } \\
\text { South } \\
\text { Central }\end{array}$ & Mountain & Pacific \\
\hline Denver & 0.0 & 0.0 & 0.0 & 0.0 & 0.0 & 0.0 & 0.0 & 64.0 & 2.2 \\
\hline Detroit & 0.0 & 0.0 & 99.3 & 60.0 & 0.0 & 0.0 & 0.0 & 0.0 & 0.0 \\
\hline Fresno & 0.0 & 0.0 & 0.0 & 0.0 & 0.0 & 0.0 & 0.0 & 0.0 & 13.3 \\
\hline Knoxville & 0.0 & 0.0 & 0.0 & 0.0 & 50.7 & 67.4 & 13.4 & 0.0 & 0.0 \\
\hline Los Angeles & 0.0 & 0.0 & 0.0 & 0.0 & 0.0 & 0.0 & 0.0 & 0.0 & 71.2 \\
\hline Minneapolis & 0.0 & 0.0 & 0.7 & 40.0 & 0.0 & 0.0 & 0.0 & 0.0 & 0.0 \\
\hline Phoenix & 0.0 & 0.0 & 0.0 & 0.0 & 0.0 & 0.0 & 0.0 & 36.0 & 0.0 \\
\hline Providence & 100.0 & 100.0 & 0.0 & 0.0 & 0.0 & 0.0 & 0.0 & 0.0 & 0.0 \\
\hline Seattle & 0.0 & 0.0 & 0.0 & 0.0 & 0.0 & 0.0 & 0.0 & 0.0 & 13.2 \\
\hline Shreveport & 0.0 & 0.0 & 0.0 & 0.0 & 17.7 & 32.6 & 80.6 & 0.0 & 0.0 \\
\hline Tampa & 0.0 & 0.0 & 0.0 & 0.0 & 31.6 & 0.0 & 6.0 & 0.0 & 0.0 \\
\hline
\end{tabular}


Table D.34. Fraction of Floor Space In Each Size Category for Each Commercial Building Type

\begin{tabular}{|l|c|c|c|c|c|c|}
\hline \multirow{2}{*}{\multicolumn{1}{c|}{ Building Type }} & \multicolumn{7}{|c|}{ Floor Space } \\
\cline { 2 - 7 } & $\mathbf{4 , 0 0 0}$ & $\mathbf{7 , 5 0 0}$ & $\mathbf{1 7 , 5 0 0}$ & $\mathbf{3 7 , 5 0 0}$ & $\mathbf{7 5 , 0 0 0}$ & $\mathbf{1 2 5 , 0 0 0}$ \\
\hline Assembly & 7.9 & 19.9 & 23.8 & 12.3 & 12.6 & 23.5 \\
\hline Education & 3.2 & 5.2 & 13.5 & 23.6 & 22.6 & 31.8 \\
\hline Food Sales & 36.4 & 6.4 & 31.8 & 19.1 & 5.1 & 1.3 \\
\hline Food Service & 40.7 & 28.8 & 24.4 & 5.2 & 0.6 & 0.3 \\
\hline Healthcare & 6.5 & 6.5 & 10.4 & 7.5 & 5.5 & 63.6 \\
\hline Lodging & 4.1 & 7.4 & 20.7 & 14.2 & 16.9 & 36.7 \\
\hline Mercantile and Service & 14.5 & 17.3 & 23.1 & 9.3 & 10.0 & 25.7 \\
\hline Large Office & 0.0 & 0.0 & 0.0 & 0.0 & 27.5 & 72.5 \\
\hline Small Office & 21.7 & 18.9 & 32.7 & 26.7 & 0.0 & 0.0 \\
\hline Other Buildings & 10.8 & 12.8 & 19.7 & 13.0 & 13.5 & 30.1 \\
\hline Warehouse & 9.5 & 11.7 & 18.0 & 13.7 & 13.5 & 33.5 \\
\hline
\end{tabular}

Table D.35. Fraction of Floor Space in Each Size Category for Each Residential Type (\%)

\begin{tabular}{|l|c|c|c|c|c|c|}
\hline \multirow{2}{*}{ Building Type } & \multicolumn{7}{|c|}{ Floor Space } \\
\cline { 2 - 7 } & $\mathbf{6 0 0}$ & $\mathbf{8 0 0}$ & $\mathbf{1 3 0 0}$ & $\mathbf{1 8 0 0}$ & $\mathbf{2 2 0 0}$ & $\mathbf{3 0 0 0}$ \\
\hline Single Family & 2.8 & 14.0 & 37.0 & 21.2 & 11.3 & 13.7 \\
\hline Mobile Home & 15.7 & 43.8 & 31.6 & 7.2 & 2.2 & 0.7 \\
\hline & \multicolumn{7}{|c|}{ Floor Space } \\
\hline & $\mathbf{1 4 , 3 0 9}$ & $\mathbf{1 9 , 0 7 9}$ & $\mathbf{3 1 , 0 0 3}$ & $\mathbf{4 2 , 9 2 7}$ & $\mathbf{5 2 , 4 6 6}$ & $\mathbf{7 1 , 5 4 5}$ \\
\hline Multifamily & 25.4 & 49.3 & 17.9 & 2.4 & 0.7 & 0.2 \\
\hline
\end{tabular}

Table D.36. Market Penetration Estimates

\begin{tabular}{|l|l|l|l|c|c|c|c|c|}
\hline \multirow{2}{*}{ Program } & Sector & Vintage & 1st Year & \multicolumn{2}{|c|}{ Penetration in Yr (\%) } & External & Internal \\
\cline { 5 - 8 } & & & of Pen. & $\mathbf{2 0 0 5}$ & $\mathbf{2 0 2 0}$ & $\mathbf{2 0 3 0}$ & Param. & Param. \\
\hline Superwindows & Residential & Existing & 2003 & 1.5 & 33.0 & 43.2 & 0.008 & 0.2435 \\
\hline Superwindows & Residential & New & 2003 & 3.0 & 65.0 & 85.0 & 0.008 & 0.2435 \\
\hline $\begin{array}{l}\text { Electrochromic } \\
\text { Windows }\end{array}$ & Commercial & Existing & 2001 & 1.8 & 17.2 & 43.2 & 0.0022 & 0.111 \\
\hline $\begin{array}{l}\text { Electrochromic } \\
\text { Windows }\end{array}$ & Commercial & New & 2001 & 2.0 & 20.0 & 50.0 & 0.0022 & 0.111 \\
\hline R30-30 roof & Commercial & Existing & 2010 & 0.0 & 15.3 & 30.2 & 0.01 & 0.3 \\
\hline R30-30 roof & Commercial & New & 2010 & 0.0 & 21.5 & 42.2 & 0.01 & 0.3 \\
\hline Quick Fill Wall & Commercial & Existing & 2004 & 0.0 & 0.0 & 0.0 & 0.01 & 0.3 \\
\hline Quick Fill Wall & Commercial & New & 2004 & 0.2 & 6.3 & 7.2 & 0.01 & 0.3 \\
\hline Quick Fill Wall & Residential & Existing & 2004 & 0.0 & 0.0 & 0.0 & 0.01 & 0.3 \\
\hline Quick Fill Wall & Residential & New & 2004 & 0.3 & 10.0 & 11.5 & 0.01 & 0.3 \\
\hline
\end{tabular}

